\title{
KURASJE
}

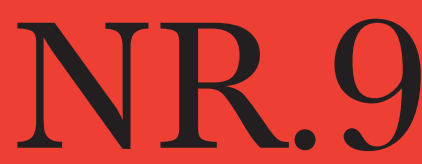

\section{ARBEJDERKOOPERATION STATSDISKUSSION}




\section{KURASJE}

TIDSSKRIFT. Abonnement kan tegnes for fire numre ad gangen, dvs. for nr. 5-8 og nr. 9-12, osv. Til abonnenter kan enkelt-numre leveres til reducerede priser, som modsvarer abonnementprisen; det samme gælder ved større bestillinger. Som sædvanligt beder vi dig om at støtte tidsskriftet ved at give det vedlagte tidsskriftsindbetalingskort videre til interesserede kammerater.

BOGIMPORT. »Marxisme med posten«. Abonnenter vil vedlagt finde et nyt bogkatalog med en oversigt over vores salg af tysk og dansk marxistisk litteratur og andre udgivelser fra undergrundsforlag. Af kataloget fremgår det, hvordan bestilling og levering finder sted. Du kan bestille flere eksemplarer af kataloget; det vil fortløbende blive suppleret.

FORLAG. Udover mindre skrifter (se kataloget) har KURASJE i det forløbne år udgivet følgende bøger: Introduktion til Kapitalens første bind; Morten Thing: Ideologier og litteratur; Paul Mattick: Krise og arbejdsløshed; Dieter Läpple: Staten og de almene produktionsbetingelser; Helmut Reichelt: Kapitalbegrebets logiske struktur hos Karl Marx. Bøger af Paschukanis, Zeleny og Neusüss er planlagt til udgivelse i foråret.

Bøgerne kan bestilles ved at benytte det vedlagte bogindbetalingskort. 


\section{TIDSSKRIFTET KURASJE NR. 9

Tidsskriftets redaktion: Thomas Boje, Nils Bredsdorff, Jens Brinch, Finn Hansson, Tyge Kjær, Ole Pedersen og Peter Søndergaard.

I $\varnothing$ vrigt har Peter Andreasen, Vilhelm Borg, Lena Fluger og Lilian Fluger medvirket som oversætter ved dette nummer.

Nummeret er udsendt den 20. februar 1974.

\section{INDHOLD}

Leder

Sigurd Jensen: Politisk uddannelse: dens samfundsmæssige

betingelser og dens muligheder og grænser for en politisering af arbejderbevidstheden $\ldots \ldots \ldots \ldots \ldots \ldots \ldots \ldots \ldots \ldots \ldots \ldots \ldots \ldots$

Kjeld Schmidt: Den moderne storindustri og arbejderbevægelsens krise. Antikritik

Konrad Frielinghaus: Bedriftskooperation

Michael Vester: Solidarisering som historisk mulighed $\ldots \ldots \ldots \ldots \quad 80$

Paul Mattick: Om begrebet statsmonopolistisk kapitalisme . . . . . . . 99

Elmar Altvater: Problemer omkring monopoler og statens rolle $\ldots \ldots 107$

Sybille von Flatow \& Freerk Huisken: Den borgerlige stats afledningsproblem

Mogens Holm: Anmeldelse af Annti Kasvio: STAMOKAP 149 


\section{Leder}

Dette nummer af KURASJE er bygget op omkring to temaer. Kooperationsformer og statsdiskussion.

I.

Konrad Frielingshaus indleder nummeret med en artikel fra 1957, hvis aktuelle baggrund er den $\varnothing$ konomiske brydningsperiode i Tyskland i midten af 50'erne. Kapitalismens rekonstruktion slår igennem her, og krigsøkonomi afløses af en begyndende velstandsøkonomi. Frielingshaus beskæftiger sig med konsekvenserne af produktivkræfternes udvikling for den umiddelbare bedriftskooperation mellem de forskellige personalegrupper i den moderne kapitalistiske enkeltvirksomhed. Unders $\emptyset$ gelsen vil afgrænse bedriftskooperationens frig $\varnothing$ rende momenter for arbejderklassen overfor farerne for en defensiv udvikling $\mathrm{i}$ de tyske bedriftsråds politiske muligheder.

Selv om Frielingshaus' artikel indeholder vigtige ansatser til konkrete analyser af den moderne enkeltvirksomhed, kan den dog ikke sige sig fri for en række indvendinger. I første række står hans klassebegreb, som er snævert funderet i det sociologiske gruppebegreb i stedet for at være udviklet af den politiske $\varnothing$ konomi. Den manglende præcision i hans begrebsbestemmelser leder direkte frem til den »socialoptimisme«, som præger hele hans artikel.

Frielingshaus' mere upræcise diskussion af dialektikken mellem reform og revolution er det direkte formulerede problemfelt hos M. Vester, som er en umiddelbar efterfølger i denne tradition, som Frielingshaus i en vis forstand er ophavsmand til. Centralt hos Vester er tesen om sammenhængen mellem »kamp- og indlæringscyklerne« og denne sammenhængs betydning for udviklingen af en revolutionær arbejderorganisering. Vester går stærkt ind for en selvorganisering og en organisering af arbejderklassens modmagt, hvor han direkte bygger på erfaringerne fra de spanske syndikalister i 1930'erne. I Danmark er disse temaer især blevet reflekteret i den kritiske diskussion om arbejdspsykologi og arbejderbevidsthed, hvor de vigtigste bidrag er kommet fra Vilhelm Borg (»Industriarbejde og arbejderbevidsthed «) og Sigurd Jensen, som i høj grad forsøger at videreføre Vesters analyser, især de som anføres i bogen »Die Entstehung des Proletariats als Lernprozess«, Frankfurt 1970. Ud fra en tese om sammenhæng mellem kooperationsform og arbejderbevidsthed 
forsøger de at udvikle en politisk psykologi omkring den bedriftsnære arbejderoplysning. I sin kritik af Sigurd Jensen forkaster Kjeld Schmidt ikke tesens grundlag, men derimod dens mangel på præcision. Kjeld Schmidt fremhæver, at denne manglende præcision skyldes, at Sigurd Jensen ikke inddrager arbejderklassens historiske klassekamperfaringer som det konstituerende element i arbejderklassens kampbevidsthed. Diskussionen mellem Kjeld Schmidt og Sigurd Jensen bliver således mere en diskussion om taktiske forskelligheder end en diskussion om grundlaget for en videnskabeliggørelse af teorien om bevidstheden overhovedet. Den grundlæggende bestemmelse af arbejderbevidstheden udfra forholdet mellem lønarbejde og kapital og dets historiske udvikling bliver ikke taget op i nogen af artiklerne.

II.

Sidste del af KURASJE nr. 9 uddyber diskussionen omkring den kapitalistiske stats begreb.

Det centrale bidrag er her Flatow og Huiskens artikel, hvoraf vi dette nummer kun bringer 1. del, men fortsætter i næste nummer. I sin helhed vil de bestemme statens begreb udfra et interessebegreb, som tager udgangspunkt i kapitalens fremtrædelsesformer, især de tre revenukilder. Grundlaget er Marx' analyse i Kapitalens 3. bog, kapitel 48.

I den foreliggende del af artiklen begrænser de sig dog til at præcisere deres udgangspunkt i forhold til Altvater (i KURASJE nr. 7) og debatten om »socialstatsillusionerne « (af Müller og Neusüss, som udkommer på dansk dette forår hos DSF).

Nummerets sidste tre artikler beskæftiger sig alle med en kritik af en af de mest udbredte statsopfattelser: forestillingen om monopolernes og statens sammensmeltning, den såkaldte StaMoKapteori, som vi hermed åbner op for en kritik af.

red. 


\section{Politisk Uddannelse:}

\section{Dens samfundsmæssige betingelser og dens mulig- heder og grænser for en politisering af arbejderbe- vidstheden.}

\section{Sigurd Jensen}

Den artikel, som bringes her, er et uddrag af en afhandling, hvor vi har udeladt afsnittet »om den bedriftsnære arbejderoplysning «. Sigurd Jensen genoptager en polemik mellem Vilhelm Borg og Kjeld Schmidt, som med udgangspunkt i Borgs bog »Industriarbejde og arbejderbevidsthed « $\mathrm{i}$ sin kerne var en diskussion om bestemmelse af kategorien »arbejderbevidsthed «. Da Sigurd Jensen i denne artikel nærmest støtter Borgs synspunkter, bringer vi i umiddelbar fortsættelse Kjeld Schmidts replik.

Dette arbejde forsøger at analysere og vurdere muligheder for en politisering af arbejderbevidstheden gennem politisk uddannelsespraxis. En sådan uddannelse, der vil udvikle og formidle arbejderbevidsthed og klassebevidsthed, kan ikke gå ud fra fiktive forudsætninger, men må klarlægge de væsentlige objektive og subjektive faktorer, der bestemmer bevidstheden. Ved objektive faktorer (=strukturelle) skal her forstås sådanne, der direkte står i sammenhæng med produktionen og dens fordeling: disse præger også udviklingen i de forskellige livsområder (familien, skolen) og ligeledes bevidstheden. Subjektive faktorer er alle de, der resulterer af menneskers og gruppers adfærd over for de objektive sociale forhold: 
herunder hører kollektive traditioner, teorier og organisationer, der alle anses for at være resultater af kollektive læreprocesser, og som også præger bevidstheden.

Analysen indskrænker sig til at omfatte industriarbejderens samfundsmæssige stilling og bevidsthed. I I. afsnit gennemgås en række centrale begreber og problemstillinger for den politiske uddannelse, og der foretages en nærmere bestemmelse af den dikotome bevidsthed. I 2. afsnit analyseres og diskuteres sammenhængen mellem arbejderens stilling i produktionsprocessen og den dikotome bevidsthed, og på baggrund heraf bestemmes den fabriksnære arbejderoplysnings mulige målsætning og funktion.

\section{I. afsnit}

\section{Marxismen: teori og praxis}

Der skal ikke her gives en mere eller mindre omfattende fremstilling af den marxistiske teori som sådan, men blot uddrages et træk, der er karakteristisk for en teori af denne type, og som har betydning i vor sammenhæng. Der tænkes på teoriens refleksivitet ${ }^{1}$, d.v.s. det forhold, at teorien ikke alene vil give en forklaring på den sociale udvikling, men også forklare betingelserne for dens egen opståen og de betingelser, hvorunder teorien anvendes. Refleksiviteten gælder altså i dobbelt henseende: dels vil teorien angive de historiske betingelser (forudsætninger) for menneskets selvrefleksion, d.v.s. angive de betingelser, som gør selvrefleksionen objektivt mulig, og dels vil den identificere og udtrykkeligt angive den adressat, der ved hjælp af teorien kan erkende sin egen samfundsmæssige position og potentielle mulighed og opgave i den historiske proces.

Således forudsætter hele Marx' værk en virkelig arbejderbevægelse, som selv er et produkt af de kapitalistiske produktionsforhold. M. Vester har i sin bog: »Proletariatets opståen som læreproces ${ }^{2}{ }^{2}$ ved hjælp af grundige empiriske studier vist, hvordan en desorienteret og fragmenteret engelsk underklasse gennem en række aktuelle kamp- og lærecyklus'er i perioden 1792-1848 først og fremmest udvikler egne kommunikationsstrukturer, der er uafhængige af borgerlige former for offentlighed og af statslig kontrol, og hvorledes underklassens medlemmer endvidere gradvist erkender nødvendigheden af at indtage en selvstændig rolle som historisk subjekt ved at opbygge egne organisationer og ved at udvikle egne teorier om det kapitalistiske samfund, dets opståen, virkemåder og ændring. Før-

1. J. Habermas: Theorie und Praxis. Frankfurt/M 1971, s. 9f.

2. M. Vester: Die Entstehung des Proletariats als Lernprocess. Frankfurt/M 1970. 
ste grundlag for klasselæreprocessen var de repressive, $\varnothing$ konomiske og kulturelle omvæltninger, der hang sammen med den første industrielle revolution og den store politiske revolution i Frankrig i 1789. I og med udviklingen og etableringen af den kapitalistiske produktionsmåde, udvikledes der i produktionen nye former for kooperation (forlagssystemet, manufaktur med arbejdsdeling), som stillede $\emptyset$ gede krav om tilpasning til arbejderne: kvinde/børnearbejde, udvidelse af arbejdsdagens længde, intensiveringen af arbejdet, tilpasning til maskiner, krav om disciplin, askese og konkurrence o.l. De nye adfærdskrav var i konflikt med den eksisterende folkekulturs antikapitalistiske værdimønstre (især forestillingerne om en økonomisk selvstændighed og et kommunalt fællesskab), og denne normkonflikt danner udgangspunkt for en klasselæreproces.

De aktuelle kampe og lærecyklus'er fulgte hinanden på den måde, at den engelske underklasse først og fremmest kæmpede for retten til at etablere egne kommunikationssammenhænge, d.v.s. retten til at danne egne foreninger og retten til at danne forsamlinger offentligt. For udviklingen af klassen til en klasse »for sig «, var etableringen af en sådan kommunikationssammenhæng, der var uafhængig af borgerlige former for offentlighed og statslig kontrol, af central betydning. Thi, først en intensiv, kontinuerlig og almen kommunikation indenfor egne presseuddannelses- og kamporganisationer muliggjorde en tilstrækkelig formulering, udveksling, efterprøvelse og videre udvikling af effektive strategier og tydningskriterier til forståelse af arbejdernes nye situation under kapitalismen. Udviklingen af et kommunikativt modsystem skete således i nær tilknytning til udviklingen af egne indholdsmæssige målforestillinger. ${ }^{3}$ Målforestillingerne hang imidlertid ikke kun sammen med etableringen af et uafhængigt kommunikationssystem, men også med arbejdernes placering i den samfundsmæssige produktionsproces. De forskellige orienteringer blev repræsenteret og udviklet af bestemte sociale grupper. Individuelt producerende havde fx. en tendens til at udvikle restaurative utopier, som skulle virkeligg øres ad politisk-parlamentarisk vej, og som indebar en tilbagevenden til førindustrielle tilstande, mens kooperativt producerende grupper kunne associere sig økonomisk og udviklede industrielle utopier, der skulle virkeliggøres gennem direkte $\emptyset$ konomiske aktioner, og som indebar en bibeholdelse af den industrielle produktionsmåde, men en radikal ændring af produktionsforholdene.

Udviklingen af selvstændige kommunikationssammenhænge og af egne mål kunne ikke ske kontinuerligt, men kun i cyklus'er. Dels forløb den industrielle revolution nemlig diskontinuerligt og vanskeliggjorde dermed arbejdernes samling, idet deres arbejdsmæssige situation ofte var så forskellig, og dels blev den nye arbejderbevægelse i stigende grad udsat for kontrol og undertrykkelse fra establishments side. En række nederlag motiverede samtidig også en regressiv læreproces hos stadig flere arbejdere: afpolitisering og opgivelsen af en

3. Ibid., s. 2If.. 
selvstændig politisk målsætning var således hæmmende momenter, der mere og mere gjorde sig gældende overfor den progressive hovedtendens.

Sammenhængen mellem den engelske arbejderbevægelses udvikling til en klasse »for sig « og de forskellige kampperioder, har Vester fremstillet som tilbagevirkninger mellem teori og praxis:

1. Utilfredshed med de ydre omstændigheder førte til en selektiv søgen efter strategier, der kunne hjælpe, og blev umiddelbart anvendt overfor det herskende system. De første nederlag blev besvaret med en forøget aktivitet, men gentagne nederlag førte til tilbagefald i apati, og der opstod et nyt behov for effektive hjælpemidler eller også mere realistiske mål.

2. Dette bevægede en 'arbejderintelligens' til at forarbejde de hidtidige erfaringer og til at udarbejde nye strategier. Analysen af nederlagene blev især foretaget af bevægelsens førende teoretikere, journalister og organisatorer. De mest betydningsfulde bidrag til den tidlige arbejderbevægelses teori præsterede 'arbejderintelligensen', som bestod af en gruppe håndværkere og industriarbejdere: deres bidrag var resultater af dels egne analyser og dels fortolkninger af teoretikere, som kom fra andre klasser.

3. Den nye strategi blev udbredt via et særligt kommunikationssystem, forarbejdet og efterprøvet i en ny kampcyklus. Vigtige formidlere var den radikale arbejderpresse, kaffehuse og primærklubber i virksomheder, hvor arbejdere forelæste, uformelle læsegrupper, foreningslokaler, demonstrationsforanstaltninger.

Den engelske arbejderklasses fors $\varnothing \mathrm{g}$ på at overtage magten i England i første halvdel af det 19. århundrede var ikke kun en politisk revolution, men begyndelsen til en socialrevolution. Bevægelsens militante holdning støttede sig på arbejdernes erfaring, at de bedre ville kunne organisere produktionen end kapitalen. Fors $\varnothing$ get endte $i$ et nederlag og frembragte den engelske reformisme, men muliggjorde også den teoretiske udvikling, som K. Marx gav stødet til. I K. Marx' værk fremtræder arbejderbevægelsens samlede erfaring (den engelske arbejderbevægelse, klassekampene i Frankrig, den tyske revolution i 1848) før 1850 i en bearbejdet form, og vi ser igen den karakteristiske adskillelse mellem proletarisk erfaring og en forarbejdning, der i alle faser relaterer sig til denne erfaring. ${ }^{4}$

Ved hjælp af teorien skal arbejderklassen kunne erkende sin egen position og historiske opgave i det kapitalistiske samfund, og teorien bliver til materiel vold, såsnart den griber masserne. (Marx). Vi vil her nøjes med at angive nogle af de vanskeligheder, der i dag existerer i forsøget på at formidle teori og praxis.

4. Ibid., s. 394ff. Jvf. ligeledes K. Korsch: »Den marx'ke teori, der uden undtagelse opfatter alle forhold og ideer i det aktuelle samfund i deres reale sammenhæng med en bestemt historisk epoke og en for denne epoke karakteristisk samfundsform, begriber også sig selv som et historisk produkt og som stående i en real sammenhæng med et bestemt trin i samfundets historiske udvikling og med en bestemt samfundsklasse«. K. Korsch: K. Marx. Frankfurt/M 1971, s. 54. 
Udgangspunktet for alle forsøg på at formidle teori og praxis idag er den kendsgerning, at arbejderbevægelsens hidtidige historie i de vesteuropæiske lande har været en historie om, hvorledes den indenfor egne rækker har reproduceret det etablerede samfunds arbejdsdeling mellem $\varnothing$ konomi, politik og teori. Mens arbejderbevægelsen oprindeligt opretholdt en meget nær forbindelse og enhed mellem den $\varnothing$ konomiske, politiske og teoretiske kamp - en enhed, der kan konstateres selv i Danmarks første arbejderbevægelse - har den idag udviklet sig til en arbejdsdelt bevægelse, hvor fagforeningerne fører en faglig- $\varnothing$ konomiskparlamentarisk kamp, medens den kritiske teori er blevet henvist til universiteterne o.l. Derfor er forsøg på at anvende teorien i en eller anden aktionssammenhæng, forbundet med store vanskeligheder, da det i praxis er et fors $\emptyset \mathrm{g}$ på at ophæve en gennem mange år fixeret samfundsmæssig arbejdsdeling, der har haft konsekvenser i alle lejre: i arbejderbevægelsen har der således længe været ført teoretiske diskussioner og diskussioner om mulige fremtidsforestillinger, og teorier vurderes af mange fagforeninger som havende ringe pragmatisk værdi. På universiteterne o.l. har intelligensen udviklet en arbejdsmåde (begreber og sprog), der ikke umiddelbart udtrykker arbejderens erfaringer.

I kølvandet på studenteroprøret i slutningen af 1960'erne har der herhjemme været fors $\emptyset \mathrm{g}$ på formidling mellem teori og praxis i form af kritiske, fabriksnære analyser og brancheanalyser af åbenbare urimeligheder i industrien. Disse fagkritiske studier har ikke alene åbnet nye perspektiver for det kritiske arbejde på universiteterne, men også tilvejebragt delvis nye informationer om situationen i industrien i dag; de er endvidere blevet diskuteret i den borgerlige offentlighed, hvor unders $\emptyset$ gelserne er blevet opfanget og neutraliseret, og de har endelig fremprovokeret den for systemet så typiske forhalingsteknik: iværksættelse af nye undersøgelser! Praktiske politiske konsekvenser af de fagkritiske tekster har imidlertid været yderst begrænset. Dette hænger tildels sammen med de kritiske studenters og venstregruppers manglende formåen til at tematisere såvel den politiske som pædagogiske side af sammenhængen mellem oplysning og aktion: dels er man gået ud fra, at analysen og den efterfølgende publikation i sig selv er i stand til at give industriarbejderne en forståelse af hans egen situation som afhængig lønarbejder, og at han derefter vil gå i aktion for at ændre de i analysen påpegede urimeligheder; derved ser man bort fra, at analyser ikke først og fremmest læses af arbejdermassen, men overvejende af det Mandel kalder for »fremskredne « arbejdere, der er skeptiske over for forslag om store aktioner, fordi de har forarbejdet den lære, man kunne drage af tidligere aktioner og ved, at punktuelle aktiviteter ingenlunde er tilstrækkelige for at nå målet. ${ }^{5} \mathrm{Og}$ dels har man indtil videre undladt at drage de praktiske-pædagogiske konsekvenser, der består i en konkret omsættelse af

5. E. Mandel: Lenin und das Problem des proletarischen Klassenbewusstseins, i: Lenin. Revolution und Politik, (ed) Suhrkamp Verlag 1970, s. 164. 
sociologiske og politiske informationer, der oftest er formaliseret og komprimeret i formalvidenskabernes sprog, til arbejdernes praktiske forståelseshorisont, således, at informationerne ikke alene tilegnes, men derudover motiverer til selvstændig politisk handlen. Konkret har denne uformåen vist sig deri, at de fleste »kritiske« søger deres livsstilling på universiteterne, for der først og fremmest at videreudvikle »teorien «, men kun sjældent forsøger at konfrontere denne teori med praxis i fx. skoler, fagforeninger o.l. I sidste ende hænger alle disse vanskeligheder sammen med, at intelligensens politisering indtil videre ikke er særligt fremskreden, at den endnu ikke har formået at identificere sine egne samfundsmæssige interesser og opbygge egne organisationer. Dette er en forudsætning for en kooperation med arbejderklassen, da oparbejdelsen af intelligensens herkomst og overskridelsen af denne, d.v.s. for de flestes vedkommende middelklassen, ikke kan ske individuelt, men kun kollektivt og politisk.

\section{Arbejdernes samfundsbillede}

Undersøgelser over arbejderens samfundsbillede foretaget i 1950'erne i vidt forskellige lande og med væsentligt forskellige metoder tyder på, at

Alle arbejdere..(..).. ser samfundet som en dikotomi - den være sig uafvendelig eller til at ændre, som delt af en kløft, som der kan slås bro over, eller som kan mindskes gennem samarbejde. Og de besvarer spørgsmålet om deres egen sociale stilling ved hjælp af en arbejderbevidsthed, der gør det muligt for dem at forstå sig selv som en del af arbejderklassen indenfor samfundet som helhed. ${ }^{6}$

For en arbejderoplysning kan disse unders $\varnothing$ gelser afgive kriterier, principper og metoder, der er begrundede i empiri. Vi skal derfor se lidt nærmere på »samfundsbilledets dikotome karakter« og »samfundsbilledets rækkevidde«, og til dette formål inddrage Popitz' o.a. undersøgelser foretaget i 1953-54 i metalindustri i Ruhr. 600 metalarbejdere blev interviewet og udspurgt om samfundsmæssige sagsforhold som rationalisering, den tekniske udvikling, medbestemmelse o.s.v. Ud fra et udvalg af 100 protokoller har de fors $\varnothing g t$ at opstille en typologi af samfundsbilleder og reaktionsmåder. Den følgende oversigt skal tjene den videre differentiering: ${ }^{7}$

6. H. Popitz o.a.: Das Gesellschaftsbild... s. 237.

7. Ibid., s. 233. Popitz o.a.'s undersøgelse er repræsentativ for en række andre undersøgelser, der alle i det væsentlige giver samme resultat. For Englands vedkommende se R. Hoggart: The uses of litteracy. Pelican Book 1958, og Frankrig A. Andrieux \& Lignon: L'ovrier d'aujourd'hui. Paris 1966. I omtalen af undersøgelsesresultaterne vil vi først og fremmest indskrænke os til den gruppe, der betragtede dikotomien som uovervindelig, da dette fænomen har vor primære interesse i dette arbejde. 
1. Typus 1 Samfundet som statisk orden

2. Typus 2 Samfundet som progressiv orden

$\begin{array}{cc}\text { Udspurgte } & \text { Typus 1-6 } \\ \% & \% \\ 10 & 14 \\ 25 & 34 \\ 25 & 34 \\ 10 & 14\end{array}$

4. Typus 4 Dikotomien som kollektiv skæbne og individuel konflikt

5. Typus 5 Reformering af samfundsordenen

6. Typus 6 Klassekamp

7. Ingen samfundsbillede

8. Rest

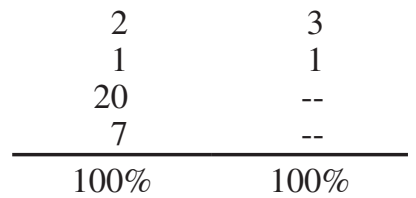

Såvel type 1 og typerne 2 og 3 (62\% ialt) betragter dikotomien, samfundets tvedeling i et »oven« og »neden«, som uovervindelig. Medens type 1 opfattede dikotomien som et udslag af en naturlovs luner, havde typerne 2 og 3 opgivet håbet om ændringer af livsbetingelserne- havde resigneret og nærede ingen tillid til arbejderbevægelsens muligheder for at ændre situationen gennem kollektiv aktion og solidaritet. Dog nærede type 4 endnu illusioner om at kunne undvige »arbejdertilværelsens trøsteløshed « ved individuelle løsninger. For typerne 3 og 4 var det først og fremmest de individuelle og kollektive erfaringer, der var ansvarlige for deres resignative holdning.

I modsætning til disse $62 \%$ industriarbejdere, betragtede ca. $38 \%$ af de udspurgte dikotomien som foranderlig: heraf anså 4\% (type 5 og 6) dikotomien som principielt og faktisk ophævelig gennem reformer eller gennem klassekamp, medens $34 \%$ (type 2) anså den som principielt uophævelig (der vil altid findes et »oven« og »neden« - derved kan intet ændres«), men dog foranderlig $i$ en grad, der fratager den den store betydning, som den har idag.

Karakteristisk for flertallet af arbejderne idag er ifølge sociologiske unders $\varnothing$ gelser altså deres resignerede og dikotome tænkemåde. Det fremgår af undersøgelsesresultaterne, at arbejderne har en fælles grundforestilling om samfundets dikotomiske opspaltning i et »oven « og »neden«, $i » d e m \ll$ og »os«. Hvis vi ser bort fra, at arbejderne ikke i streng forstand skelnede mellem besiddere og ikke-besiddere af produktionsmidler (undertiden blev selv deres 'egen' arbejdsdirektør medregnet blandt »dem der oppe«), så svarer denne opspaltning af samfundet i to dele omtrent til en klassemodel, og for så vidt modbeviser undersøgelsesresultaterne alle teorier og ideologier om, at arbejderklassen er ved at blive opløst, og at arbejderne er ved at blive - eller er blevet - »integreret« i det kapitalistiske samfund.

Men på den anden side er den dikotome bevidsthed heller ikke nogen klassebevidsthed, da samfundets opspaltning fremtræder som noget naturlovsagtigt og uovervindeligt, og ikke som noget historisk udviklet, der er betinget af selve kapitalforholdet, og som derfor også kan afskaffes gennem arbejderklassens 
kollektive aktioner. Dertil kommer, at arbejderens tænkning er præget af personaliseringstendenser, d.v.s. - enkelte personer gøres ansvarlige for sociale fænomener, der i virkeligheden har deres grundlag i de objektive samfundsmæssige strukturer og processer. Denne holdning karakteriserer ikke kun arbejderen, men stort set alle samfundsgrupper. ${ }^{8}$

Spørgsmålet er nu, hvordan man kan forstå relationen mellem den dikotome bevidsthed og klassebevidsthed: hvad betyder og udtrykker dette strukturelement i arbejdernes tænkning? Elmar Altvater mener, at den objektive modsætning mellem lønarbejde og kapital potentielt er indeholdt i dikotomien. ${ }^{9}$ På linie hermed betragter $\mathrm{O}$. Negt den dikotome bevidsthed som et udtryk for den objektive modsætning. Ifølge sidstnævnte, kan den resignerede og dikotome tænkemåde hverken forstås som et forfaldsprodukt af den traditionelle, politiske bevidsthed eller som udtryk for en pariamentalitet eller et individuelt forlis, men snarere som en bevidsthed med »intentioner mod klassebevidsthed«: klassesamfundets objektive polarisering manifesterer sig i dette strukturelement på den praktiske følelses trin:

Det Hegel kalder en 'praktisk følelse', går i skikkelse af det bestemmende $\emptyset$ nske om ikke længere at ville være arbejder igen hos arbejderne i samtlige ytringer, som vedrører den subjektive bestridelse af arbejderens totalsituation. En 'praktisk følelse' omfatter ifølge sin natur allerede fornuftens indhold, et engagement over for det givne, men vel at mærke kun som et umiddelbart, naturligt og subjektivt indhold, der først kan opnå form af almenhed og nødvendighed, objektivitet og sandhed gennem videnskabelig bevidsthed. ${ }^{10}$

Negt mener, at man med sikkerhed kan slutte ud fra det foreliggende empiriske materiale angående arbejderens 'politiske apati', lønutilfredshed etc., at arbejderen af idag lever i en permanent spænding mellem følelsen af sine sociale livsbetingelsers uafvendelighed og ønsket om ikke længere at skulle være arbejder, og at denne spænding vokser i samme udstrækning, som udviklingen af produktivkræfterne $\varnothing$ ger modsætningen mellem den private disposition over produktionsmidlerne og samfundsmæssig produktionsmåde på den ene side, mens arbejderens villighed til at identificere sig med arbejderbevægelsens traditionelle mål på den anden side slækkes. ${ }^{11}$

Denne modsætning: han vil ikke længere være arbejder og kan dog ikke befri sig for følelsen af altid at skulle være det, bestemmer såvel arbejderens interesser som samfundsbillede. Han har en praktisk følelse af, at han er den udbyttede og hører blandt de undertrykte her i samfundet: han ved det kun som noget »umiddelbart« og »naturligt« d.v.s. han kan endnu ikke gennem egne udtryksformer give udtryk for sin erkendelse og interesse i en almen og

8. M. Teschner: Zum Verhältnis von Betriebsklima und Arbeitsorganisation. Frankfurt/M 1961, s. 44f.

9. E. Altvater: Produktive und unproduktive Arbeit als Kampfbegriffe, i: Sozialistische Politik, nr. 8 1970, s. 62.

10. O. Negt: Soziologische Phantasie und exemplarisches Lernen. Frankfurt/M 1971, s. 56.

11. Ibid., s. 33. 
nødvendig form. Dette hænger sammen med bl.a. sprogets store betydning for organiseringen af erfaringer og forestillingsindhold (politiske indstillinger, samfundsbilledet, fortolkningen af interesser og behov, målforestillinger). Den erfaring om arbejdertilværelsens trøstesløshed, der begynder i familien, skolen og som fortsætter i fabrikken, kan kun vanskeligt udtrykkes ved hjælp af det 'offentlige sprog' ${ }^{12}$, som arbejderen er henvist til at bruge i sin begrebsdannelse, sit ordvalg og i sin sætningsopbygning. Sprogformens mangel på logisk komplexitet har således først og fremmest en række logiske følger for brugeren af dette sprog: et lavt begrebsniveau, der begunstiger deskriptiv tænkning, en preference for det aktuelt givne, en orientering mod lav kausalitetsgrad og mod personer, ting og begivenheder snarere end mod strukturer, processer og mere komplexe sagsforhold. Der får arbejderen oftest formuleringsvanskeligheder, selv når han overfor andre skal beskrive sin umiddelbare erfaringsverden - en vanskelighed, der tiltager i samme omfang, som hans tænkning fjerner sig fra denne. Dertil kommer, at det offentlige sprog er et såkaldt implicit sprog, hvor de sproglige ytringer primært opfylder den funktion at bekræfte og udvide den sociale kommunikation, men hvor betydningen af det individuelt mente derimod ikke fattes sprogligt og dermed begrebsmæssigt: arbejderen får derfor vanskeligheder med at udtrykke sine individuelle erfaringer med samfundsmæssige og individuelle konflikter. Disse sprogligt betingede vanskeligheder medfører nu, at arbejderen ofte må gribe til stereotype standardformuleringer, når han overfor andre forsøger at udtrykke sine erfaringer og interesser. Disse stereotyper, der især tilbydes af massemedierne, indeholder forestillinger om samfundsmæssige forhold og historiske sammenhænge, og tilbyder endvidere »forklaringer « på arbejderens situation idag: »det har aldrig været anderledes, nogle bestemmer, de andre må adlyde og indordne sig «, »dem, der er noget, har også noget at skulle have sagt«, »den kloge narrer den mindre kloge « osv.

Denne »binding « af følelser, frygt, håb og forventninger til stereotyper, er med til at blokere arbejderens erkendelse om egne interesser. (Dette gælder dog ikke uden videre i de tilfælde, hvor stereotyperne udtrykker arbejderbevægelsens kollektive erfaringer - jvf. senere under social topik'). Men til grund for denne griben tilbage til stereotyper ligger et frigørende potentiale, for så vidt der er tale om et selvstændigt fors $\emptyset \mathrm{g}$ på at begribe de virkelige forhold, sådan som de er, altså et fors $\emptyset \mathrm{g}$ på ved hjælp af fornuften at vinde indsigt i den historiske proces og i vor samfundsordens antagonistiske karakter, som forhindrer såvel hans som andres fornuftige og tilfredsstillende samliv. Dog er også selve forsøget modsætningsfyldt for så vidt det nok angiver vejen, der fører til en forståelse af virkeligheden, men denne vej søges over simplificeringer, d.v.s. ved hjælp af et urealistisk, ideologisk verdensbillede. Dette sidstnævnte »ønske om simplificering «kan ikke

12. B. Bernstein: A public Language: some Sociological implications of a Linguistic form, i: The British Journal of Sociology (X) 1959. 
betragtes som værende et oprindeligt behov, men må snarere ses som et resultat af arbejdernes defensive erfaringer med den borgerlige offentlighed. ${ }^{13}$

Denne tvetydighed $\mathrm{i}$ arbejdernes fors $\emptyset \mathrm{g}$ på at begribe de virkelige socialle forhold, og som altså yderligere kompliceres af det forhold, at hans egen aktivitet »tildækkes « af de ovennævnte stereotyper, vedrører hele arbejderens sociale adfærd.

\section{Afsnit}

\section{Årsagerne til samfundsbilledets dikotome karakter og resignative moment}

Man kunne nu stille sig spørgsmålet, hvorfor det førnævnte frigørende behov, hvis realisering gennem erfaringsunderbyggede kollektive aktioner i sidste ende ville betyde lønarbejdets ophævelse, hvorfor dette behov ikke kan manifestere sig i en form (organisation etc.), der korresponderer med sit indhold. Dette spørgsmål tages op senere under »vilde strejker « og »arbejderkollektivet«. Et andet vigtigt spørgsmål er, hvorfor den typiske arbejder' af idag føler sig afmægtig og har resigneret, opgivet håbet om ændringer af livsbetingelser. Hvorfor han betragter dikotomien som uafvendelig, som udtryk for en naturlov, som noget man ikke kan ændre gennem egenvirksomhed indenfor rammerne af en kollektiv aktion?

Det giver sig selv, at dette sidste spørgsmål er af afgørende betydning for ens fors $\emptyset \mathrm{g}$ på at etablere en forbindelse mellem teori og praxis. Hvis man fx. kom frem til den opfattelse, at afmægtighedsfølelsen og resignationen hang sammen med den tekniske/teknologiske udvikling i produktionsprocessen, ville der ikke være grund til at »tilsmudse« Teorien, ved at anvende den i en eller anden historisk aktionssammenhæng. (Den rene teoris politiske abstinens). Finder man derimod ud af, at der er tale om historiske og dermed foranderlige sociale forhold, ville ens politiske interesser - gennem teorien og dens objektiveringer (arbejderblade, - rapporter, arbejderoplysningspraxis etc.) - kunne manifestere sig i en eller anden aktionssammenhæng (organisation, gruppering, etc.).

\section{Den teknologiske determinisme}

Den teknologiske determinisme, som bl.a. Blauner ${ }^{14}$ er talsmand for, hælder til den anskuelse, at den tekniske/teknologiske udvikling automatisk (med objektiv nødvendighed) medfører en given bevidsthed om sig selv og samfundet.

13. O. Negt/A. Kluge: Öffentlichkeit und Erfahrung. Zur organisationsanalyse von bürgerlicher und proletarischer Öffentlichkeit. Frankfurt/M 1972, s. 81.

14. R.|Blauner: Alienation and freedom. Chicago \& London 1964. 
Blauner har undersøgt, hvorledes arbejdsprocessens teknologiske og sociale organisation, som erfaringsbetingelser for arbejderen, determinerer hans erfaringer med følelser såsom kontrol over det umiddelbare arbejdsforløb resp. dominering, mening i arbejdet resp. nyttesløshed, hans følelse af social forbindelse resp. isolation og endelig hans følelse af spontan involvering resp. desengagement og utilfredshed. ${ }^{15}$ Han finder frem til, at disse erfaringsaspekter hænger sammen med produktionsmåden på en sådan måde, at »fremmedgørelsen « bliver minimal i den håndværksmæssige og automatiserede produktion (typografer resp. kemiarbejdere), men derimod høj i den maskinbestemte produktion og samlebåndsproduktionen (tekstilarbejdere resp. automobilarbejdere).

Blauners position tager imidlertid ikke højde for, at produktionsprocessen under kapitalistiske produktionsforhold har to aspekter, at produktionsprocessen må anskues som en enhed af arbejdsproces og værdiskabende proces: dels er den materielle arbejdsproces en formålsrettet aktivitet med sigte på fremstilling af brugsværdier til opfyldelse af menneskelige behov, og dels er den middel i kapitalens merværdiproduktion. Denne dobbeltsidighed af selve produktionsprocessen bevirker, at også ledelsen i den enkelte fabrik bliver dobbeltsidig efter sit væsen, nemlig

ikke blot en funktion, der udspringer af den samfundsmæssige arbejdsproces' natur og derfor henhørende til og særegen for den, den er tillige en samfundsmæssig arbejdsproces' udbytningsfunktion, og den er derfor betinget af den uundgåelige antagonisme mellem udbytteren og råmaterialet for hans udbytning ${ }^{16}$.

Det er derfor ikke alene, endsige primært, arbejdsprocessens teknologiske og sociale organisation, der konstituerer erfaringsbetingelser for arbejderen, men derimod denne objektive modsætning mellem på den ene side kapitalisten og dennes repræsentanter, der primært er interesserede i en forøgelse af den indskudte kapital, og på den anden side arbejderne, som er interesserede i at beskytte, bevare og udfolde deres egne produktive kræfter.

Heller ikke den automatiserede produktion vil ændre på dette forhold: Strukturforandringerne i industrien vil nok afskaffe de mest stupide, repititive arbejdsformer og - forløb i kooperationen, og dermed også give producenterne muligheder for større kontrol over det umiddelbare arbejdsforhold, større muligheder for at få et meningsfuldt arbejde, men kan identificere sig med. Men de vil ikke ophæve den form ved arbejdsprocessen, der er bestemt af kapitalens forøgelsesinteresser, og som fortsat vil konstituere erfaringsbetingelser for de højtkvalificerede arbejdere (ingeniører, teknikere).

Den omtalte form ved arbejdsprocessen, resulterer nødvendigvis i såkaldte strukturelle konflikter, der optræder på såvel et samfundsmæssigt plan som i

15. Ibid., s. 7.

16. K. Marx: Kapitalen. København 1971, s. 493. 
den enkelte virksomhed og har en afgørende betydning for udviklingen af arbejdernes kollektive selvbevidsthed: netop sådanne konflikter med andre grupper skaber en kollektiv bevidsthed, en bevidsthed om interessemodsætningen mellem arbejdergruppen og virksomhedsledelsen.

\section{Arbejderklassens historiske nederlag}

I Proletar! har K. Schmidt argumenteret for en historisk forklaring på arbejderens resignation og afmagtsfølelse. Han vender sig udtrykkelig mod den anskuelse, at det skulle være selve den store industris indførelse, der er årsagen til »arbejderbevægelsens åbenbare krise«, at afmagtsfølelsen og resignationen altså skulle hænge sammen med det forhold, at det i storindustrien bliver selve maskinsystemet, der behersker arbejderen og dikterer dennes bevægelse og kooperationen. ${ }^{17}$

K. Schmidts udgangspunkt er den såkaldte »Tayloristiske « offensiv mod arbejderbevægelsen omkring 1880. Hensigten med denne offensiv var at hente merværdi til den trængende kapitalakkumulation ved at fratage arbejderne al vigtig beslutningstagen og planlægning, som kan påvirke størrelsen af fabrikkens produktion ${ }^{18}$ ), ved at arbejdsdelingen mellem intellektuelt og fysisk arbejde skulle føres ud i sin extrem. Denne offensiv fandt imidlertid sin grænse i sin daværende produktionsmåde, som var karakteriseret ved, at enkelte faglærte arbejdere betjente enkelte maskiner (fx. en drejebænk), og det var derfor, når alt kommer til alt, den enkelte arbejder, der havde det afgørende ord at skulle have sagt om, hvorledes tingene skulle klares, og de kunne også selv regulere arbejdsintensiteten. De satte sig derfor aktivt til modværge overfor Taylors fors $\emptyset \mathrm{g}$ på at forværre deres arbejdsbetingelser, som ville være den praktiske konsekvens af forslaget om at føre arbejdsfordelingen mellem intellektuelt og fysisk arbejde ud i sin extrem.

Da den »Tayloristiske« offensiv således fandt sin effektivitetsgrænse i dels den daværende dominerende produktionsmåde og dels arbejdernes aktive modværge, var nedkæmpelsen af den militante arbejderbevægelse (især i metal- og maskinindustrien) en afgørende forudsætning for, at det Tayloristiske princip kunne føres ud i sin fulde logiske konsekvens, d.v.s. at den moderne storindustri kunne blive den dominerende produktionsmåde og dermed hente relativ merværdi til den hårdt trængende kapitalakkumulation. Denne klassekamp strakte sig over 40 år (1880-1920'erne) og endte med arbejderklassens nederlag i det verdenshistoriske opg ør i den Første Verdenskrigs sidste år og i de første efterkrigsår. Den efterfølgende krise, desorganisering, desintegration og fragmentering skabte dermed betingelserne for den moderne industris sejrsgang. I sidste halvdel af 1920'erne slog den moderne storindustri igennem i Vesteuropa. For arbejderklassens medlemmer betød dette en radikal forværring af deres arbejdsbetingelser: den moderne storindustris integrerede system af specialmaskiner,

17. K. Schmidt: Den moderne storindustri og arbejderbevægelsens krise, i: Proletar nr. 3 nov. 1972, s. 6.

18. Ibid., s. 6-8. 
fratog arbejderen den føromtalte selvbestemmelse i arbejdsprocessen. Specialmaskinernes indbyrdes samarbejde besørges og reguleres nu af transportbåndet, og maskinsystemet dikterer ligeledes den enkelte arbejders arbejdstempo.

Man kan sammenfatte K. Schmidts position således: den resignation og afmagtsfølelse, som en række sociologiske undersøgelser fra 1950'erne har kunnet konstatere blandt flertallet af industriarbejdere, skyldes ikke den moderne storindustris indførelse, d.v.s. det forhold, at det nu bliver maskinsystemet, der behersker arbejderen og dikterer dennes bevægelser og kooperationen, men snarere arbejderklassens historiske nederlag. Den moderne storindustri har ikke engang cementeret dette nederlag. Afmagtsfølelsen og resignationen er snarere blevet cementeret af en række nye historiske nederlag: det kommunistiske partis forvandling (Stalin-perioden), den socialdemokratiske reformismes totale fallit overfor det kapitalistiske systems kriser, den facsistiske kontrarevolution og dens ødelæggelse af arbejderbevægelsens faglige organisationer, den Anden Verdenskrig og den efterfølgende besættelse, den Kolde Krig og den begyndende højkonjunktur i 50'erne:

Størstedelen af de arbejdere, der havde været igennem disse omvæltninger, og som nu stod absolut desorganiseret følte sig magtesløse, var modløse og hengav sig til privatlivets nydelser ${ }^{19}$.

Derfor kunne Popitz da også konstatere, at arbejderen i 1950'erne nok så samfundet som en dikotomi, d.v.s. som et klassesamfund, men at det store flertal endvidere betragtede samfundets opdeling $\mathrm{i} » d e$ øverste $\ll$ og $»$ de underste« som uafvendelig, noget man ikke kunne ændre på.

Heller ikke af automationen forventer K. Schmidt sig noget særligt. Automationen indebærer i virkeligheden en radikal forværring af arbejdsbetingelserne, og er blot et nyt angreb på arbejderklassen, thi som altid er maskinerne midler til produktion af merværdi. Kun produktionens »flaskehalse« automatiseres og de nye arbejdsfunktioner (montage, vedligeholdelse etc.) forbliver atypiske. Størstedelen af produktionssystemet forbliver uændret - kun tempoet skrues yderligere op.

Positionens styrke er dens historiske perspektiv - klassekampperspektivet. Den inddrager en række historiske nederlag - såvel nationale som internationale -, der ikke har tilført arbejderklassen nye erfaringer, men snarere destrueret allerede gennem tidligere aktioner vundne erfaringer, d.v.s. bevirket et tab af proletarisk historiebevidsthed. Arbejderklassens traditioner, som indeholder positive og negative elementer, d.v.s. som er en historie med højdepunkter og nederlag, har en afgørende betydning for arbejdernes kollektive selvbevidsthed (-vurdering) for så vidt det er sandsynligt, at en gruppe, der ikke kender én - i en eller anden forstand - heroisk fortid, men kun kan se tilbage på nederlag, - at en sådan gruppe også vil resignere overfor fremtiden! I denne resignative holdning, der ofte udtrykkes i standardformuleringer såsom: »Vi arbejdere forbliver altid de dumme,

19. Ibid., s. 5 . 
derved kan intet ændres, - kapitalen er for stærk «, ligger også en kollektiv selvvurdering. Den har afgørende indflydelse på deres handlen resp. ikke-handlen, og dermed også for deres politiske bevidsthed og klassebevidsthed.

Tilbage bliver spørgsmålet, hvorvidt alle nederlag fører til destruktive erfaringer af ovennævnte art. Om nederlag ikke også kan resultere i frigørende erfaringer i den forstand, at de ikke forsvinder i og med, at nederlaget er en kendsgerning, men indgår i arbejderklassens efterfølgende erfaringsdannelse (gennem aktioner etc.). Problemet skal blot antydes i denne sammenhæng. Måske forholder det sig sådan, at det alene er historisk udsigtsløse kampe, d.v.s. kampe, der aldrig burde være taget op, da de ikke havde en materiel og afviselig basis, og kampe med fejlagtigt afstukkede mål, som aldrig vil kunne forbedre den samfundsmæssige erfaring og massernes færdighed til at organisere erfaringer. At kampene alligevel blev taget op, kan skyldes massernes eller ledernes forkerte vurdering af den materielle totalsammenhæng. ${ }^{20}$

Positionens svaghed er imidlertid, at den underkender betydningen af selve den specifikke objektverden, der møder arbejderens adfærd og hans bevidsthed om denne adfærd? Har den moderne storindustris extreme arbejdsdeling, som bevirker, »at flertallet af arbejdernes produktive aktivitet er blevet reduceret til tom, abstrakt aktivitet, til et vedhæng til maskinerne, og at dens sammenhæng med de andre arbejderes aktivitet er fastlagt i maskineriet, altså fremmedbestemt $\ll^{21}$ - har hele denne specifikke objektverden ingen betydning for arbejderens adfærd og hans bevidsthed om samme. Og hvis der virkelig kan konstateres empiriske sammenhænge mellem selve det konkrete arbejde i fabrikken og bevidsthedsformer, hvilken betydning har det da for udviklingen af en politisk bevidsthed? Spørgsmålene skal søges besvaret ved en inddragelse af V. Borgs unders $\varnothing$ gelse af sammenhængen mellem det industrielle arbejdes udvikling og arbejderbevidsthed.

\section{Den store industris fremmedbestemte kooperationsform}

V. Borg finder frem til, at den dikotome bevidsthed kan betragtes som et udtryk for den objektive modsætning mellem kapital og lønarbejde, som konstitueres i og med kapitalens formelle og reale underordning af arbejdet. ${ }^{22}$ Det skal uddybes nærmere.

20. O. Negt/A. Kluge: Öffentlichkeit und Erfahrung. Zur organisationsanalyse von bürgerlicher und proletarischer Öffentlichkeit. Frankfurt/M 1972, s. 403.

21. V. Borg: Industriarbejde og arbejderbevidsthed. København 1971, s. 49.

22. Med »kapitalens formelle underordning af arbejdet « menes det forhold, at kapitalen ved overgangen fra feudalsamfundet til det kapitalistiske samfund overtager de produktionsmåder, som forefindes i feudalsamfundet, uden at ændre ved selve arbejdets karakter. På basis af denne formelle underordning udvikles »kapitalens reale underordning af arbejdet «: kapitalens selvforøgelse sker nu primært gennem en ændring af selve arbejdsprocessen, ved fuld udnyttelse af arbejdsdeling anvendelse af maskiner og udvikling af kooperationen. Se V. Borg: Industriarbejde og arbejderbevidsthed, kap. 2 og 3. 
Under den store industri henter den altid trængende kapitalakkumulation sin merværdi ved at ændre selve arbejdsprocessen, hvorved enkeltkapitalen skaber sine egne betingelser for den videre kapitaltilvækst. Arbejdsprocessen ændres nu først og fremmest ved at kooperationen udvikles. Kooperationen er den form arbejdet antager, når mange arbejder planmæssigt side om side eller i fællesskab i samme produktionsprocesser: der er ikke tale om en $\emptyset$ gning i de individuelle arbejderes produktivkraft, d.v.s. deres formåen til, gennem deres individuelle arbejde og under anvendelse af bestemte produktionsmidler og en deraf betinget samarbejdsart, at fremstille materielle midler til tilfredsstillelse af samfundsmæssige livsbehov, der er derimod tale om en ny produktivkraft, en kollektiv kraft, en fra første færd af samfundsmassige produktivkraft. Under kapitalistiske produktionsforhold fremtræder denne nye kraftpotens imidlertid som en produktivkraft, der er kapitalen naturgivet, som kapitalens iboende produktivkraft, og ikke som en kraft, der udspringer af det samfundsmæssige arbejdes forøgede produktivitet. Producenterne forholder sig ikke til den kooperative kraft som deres egen bevidste kollektive kraft. Dette skyldes to forhold, nemlig dels, at den samfundsmæssige produktivkraft ikke koster kapitalen noget - kapitalisten betaler jo kun værdien af de enkelte arbejdskræfter -, og dels, at kooperationen ikke udvikles af arbejderne i fællesskab, da de uafhængigt af hinanden og enkeltvis indtræder i et forhold til samme kapital, men ikke til hinanden: Deres kooperation begynder først i arbejdsprocessen, men i arbejdsprocessen er de allerede ophørt med at være deres egne herrer. ${ }^{23}$

Den revolutionære pointe i Marx' begreb 'produktivkraft', og herunder altså også kooperationen, består nu i påvisningen af, at der i løbet af samfundets (produktionens) udvikling vil ske en uophørlig forøgelse af den nye kraftpotens, af den kollektive, samfundsmæssige produktivkraft. På linie hermed kan endda selve den revolutionare arbejderklasse betragtes som en materiel produktivkraft, for så vidt den gennembryder de hindringer, den kapitalistiske vareproduktion sætter for produktivkræfternes udvikling, erstatter den borgerlige arbejdsdelings ufuldkomne former med en direkte socialistisk socialisering og dermed egentlig først fuldt ud virkeligg $\varnothing r$ den nye kraftpotens, der allerede dynamisk er indeholdt i det samfundsmæssige arbejde. ${ }^{24}$

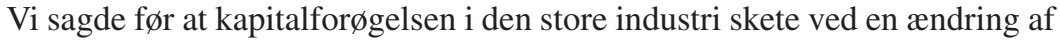
selve arbejdsprocessen. Den store industri ændrer nu arbejdsprocessen ved at føre arbejdsdelingen mellem intellektuelt og fysisk arbejde ud i sit extrem, og ved at anvende maskinsystemer, der betinger kooperationen.

Medens det i håndværksproduktionen er arbejderen, der bevæger værktøjet, underordnes hans aktivitet $\mathrm{i}$ den store industri maskineriets rytme og tempo. Både den enkelte arbejders arbejde og arbejdernes kooperation er fastlagt $\mathrm{i}$

23. K. Marx: Kapitalen. København 1971, s. $495 f$.

24. K. Korsch: K. Marx. Frankfurt/M 1971, s. 168. 
maskinsystemet. Popitz o.a. har givet en nærmere karakteristik af den store industris typiske kooperationsform (= den strukturelle kooperation), som de enkelte arbejdere, foruden de objektive arbejdsbetingelser, konfronteres med, når de træder ind i produktionsprocessen: ${ }^{25}$

1. Den strukturelle kooperation fastlægger ikke alene en given arbejdsdeling, men fastlægger og formidler også arbejdernes kooperation. Arbejderne arbejder ikke direkte med hinanden, men indirekte, formidlet over (gennem) selve det tekniske anlæg. (jvf. fx. en samlebåndsproduktion).

2. Den enkelte arbejders bevægelighed er vidtgående begrænset, da selve det tekniske anlæg foreskriver en fast systematik i arbejdspladsernes indbyrdes forhold.

Arbejdernes muligheder for at fordele arbejdet mellem sig, bliver (er) minimale, da selve det tekniske anlæg foreskriver en fast opdeling af arbejdsopgaver. Hver enkelt arbejder har en skarpt afgrænset funktion i arbejdsprocessen. Arbejdsdelingen er altså i princippet uophævelig.

4. Også i tidsmæssig henseende er den enkelte arbejders arbejde i høj grad determineret, da selve det tekniske anlæg foreskriver en bestemt tidsfølge for arbejdsfunktionerne.

5. Arbejderne kan ikke uden videre hjælpe hinanden i løsningen af deres individuelle arbejdsopgaver, men kun indirekte ved fx. at korrigere andres fejl gennem en kvalitativ ændring i ens egen arbejdsproces (-operation).

Arbejdet $\mathrm{i}$ en sådan kooperationsform er dels præget af stupide og repititive arbejdsoperationer og arbejdsløb, da arbejdet af ingeniører og teknikere er blevet nedbrudt til dets mest simple operationer. For de enkelte arbejdere betyder dette, at deres færdigheder (planlægnings- og kontrolfærdigheder) begrænses. Men derudover er arbejdet i en sådan kooperationsform samtidig præget af et enormt tempo. Maskinsystemets (fx. et samlebånds) hastighed, som arbejderne selvfølgelig ikke kontrollerer i en kapitalistisk virksomhed, bestemmer arbejderens bevægelser hele arbejdsdagen. Det er da også dette aspekt ved arbejdet, som de fleste arbejdere hader mest: »Det er ikke ensformigheden, det er tempoet, tempoet, tempoet «. Arbejderne under den store industris kooperationsform, betragter da også gennemgående deres arbejde som en plage, som slid og brug af energi, og ikke som deres egen produktive aktivitet, ikke som noget de kan identificere sig med. Deres krav om ændringer i arbejdsprocessen angår først og fremmest mindre belastende arbejde og højere $1 \varnothing n .^{26}$

Den dikotome bevidsthed betragtes nu af Borg som et resultat af lønarbejdernes fælles erfaringer gennem mange år under den store industris kooperationsform. Netop det faktum, at alle arbejdere under den store industris fremmedbestemte

25. H. Popitz o.a.: Technik und Industriearbeit. Tübingen 1957. Se også V. Borg: industriarbejde og arbejderbevidsthed, s. $27 \mathrm{ff}$.

26. V. Borg: Industriarbejde og arbejderbevidsthed, kap. 4 og 5. 
kooperationsform indtager positioner under hierakiet og overvejende udøver rent udførende arbejde bevirker, at deres bevidsthed - i modsætning til funktionærernes hierakisk bestemte bevidsthed - bliver dikotomisk: udfra denne position er »verdenen« faktisk inddelt i to områder, et »oven« og »neden«. Den dikotome bevidsthed videreformidles til de enkelte arbejdere gennem opdragelsen i arbejderfamilier og deres deltagelse i arbejderkollektivet i virksomhederne. ${ }^{27}$

Efter således at have karakteriseret erfaringsbetingelserne for arbejderne under den store industris fremmedbestemte kooperationsform, hvor arbejderens produktive aktivitet gennemgående er blevet reduceret til et vedhæng til maskinen og hvor dens sammenhæng med de andre arbejderes aktivitet er fastlagt i maskineriet, altså fremmedbestemt, skal vi gå over til at omtale arbejderens erfaringer med konflikter, som er uløseligt forbundet med arbejdet i denne kooperationsform.

I indledningen sagde vi, at enkeltkapitalen henter sin videre kapitaltilvækst ved at ændre selve arbejdsprocessen.

Men jo mere kapitalen forøges, jo vanskeligere bliver den videre forøgelse i samme tempo. Dette medfører, at der i det kapitalistiske samfund med jævne mellemrum forekommer kriser, depressioner eller lavkonjunkturer med en lavere $\varnothing$ konomisk vækst... Disse modsætninger mellem den stadige stigning i arbejdets produktivitet og $\mathrm{i}$ dets intensitet på den ene side og de tilbagevendende kriser, depressioner, og lavkonjunkturer på den anden side giver sig udtryk i tiltagende konflikter i produktionsprocessen. ${ }^{28}$

Den enkelte kapitalist er nemlig i og med de $\varnothing$ vrige kapitalers konkurrencepres og vanskelighederne med at bevare den samme takt i værdiforøgelsen, tvunget til at nedskære omkostningerne ved produktionen, d.v.s. for at forøge udbytningen ved at rationalisere yderligere, ved at forøge arbejdstempoet, ved at foretage afskedigelser, lønsænkninger, endnu strengere kontrol over arbejderne o.l. Dette $\emptyset$ gede tryk mod arbejderne, dette angreb mod arbejdskraften, tvinger dem til at gøre modstand for at forsvare deres interesser. Konflikten i den kapitalistiske produktionsproces kan antage former såsom »den organiserede produktionsbegrænsning «, »en vild strejke«, »sabotage«, »fabriksbesættelse «, »arbejd-efter-reglerne« o.l. Imidlertid har arbejdernes muligheder for at gøre og organisere erfaringer med konflikter hidtil været begrænsede,

da lønarbejdernes selvvirksomhed gennem mange år er blevet behersket af burokratiserede fagforeninger og partier i samarbejde med borgerklassen og staten. Ved at arbejderne er blevet forhindret i ved selvvirksomhed at opnå erfaringer om deres egen styrke, er magtesløsheden, resignationen og bevidstheden om »dem der oppes « uovervindelige magt blevet bekræftet gang på gang. ${ }^{29}$

27. Ibid., s. 49.

28. Ibid., s. 30.

29. Ibid., s. 50. 
På den anden side kan den dikotome bevidsthed også fremover kun overvindes gennem de daglige konflikter i virksomheden. Kun arbejderklassens egen førte klassekamp kan være deres læremester.

\section{Diskussion}

Medens Blauners teknologiske determinisme, der består i antagelsen om en retlinet sammenhæng mellem den tekniske/teknologiske udvikling i produktionsprocessen og arbejderens »fremmedgørelse«, på det bestemteste må afvises, har K. Schmidts konsekvent historiske standpunkt den fordel, at den ser arbejderens dikotome bevidsthed som et resultat af arbejderklassens såvel nationale som internationale klassekamperfaringer. Da han imidlertid ligeså konsekvent abstraherer fra den betydning, som selve den materielle produktionssammenhængs specifikke objektverden har for arbejderens adfærd og bevidsthed om samme, havner han uværgerligt i den teknologiske determinismes velkendte modpol: voluntarismen, problemet om, hvorledes en arbejdermasse konstituerer sig som en klasse for sig selv, ledes dens objektive tilskrevne interessesituation bliver dens virkelige interesser, som den effektivt sætter igennem over for såvel kapitalistklassen som staten, - dette afgørende problem reduceres af K. Schmidt til det han kalder praktisk-politiske problemer, nemlig: opbygning af en bred militant arbejderbevægelse og opbygning af et rodfæstet og handlekraftigt revolutionært arbejderparti. ${ }^{30} \mathrm{Ud}$ af $»$ revolutions-modellen « falder arbejdernes selverfaringer. Det skal uddybes nærmere.

Som tidligere omtalt, er K. Schmidt af den opfattelse, at den store industris kooperationsform hverken er årsagen til eller har cementeret »arbejderbevægelsens krise «, således, som den kommer til udtryk i det forhold, at flertallet af arbejderne føler sig afmægtige, resignerede og har opgivet håbet om ændringer af deres livsbetingelser: dels indtrådte arbejderbevægelsens krise allerede omkring 1920, medens den store industris strukturelle kooperation først blev almen i Vesteuropa omkring 1930, og dels har den moderne storindustris højborg: den amerikanske automobilindustri, modbevist al snak om passivisering af arbejderen, da den »har været skueplads for en offensiv og militant arbejderbevægelse, hvis lige man skal lede længe efter.«

Hvad angår det første argument, vil alene en grundig historisk analyse og rekonstruktion af situationen før, under og efter 1. Verdenskrig kunne afgøre, hvorvidt den resignation og afmagtsfølelse, som bl.a. Popitz kunne konstatere i 50'erne, nu virkelig kun har sit grundlag i det verdenshistoriske nederlag. K. Schmidt leverer ikke selv en sådan analyse, og indtil videre må vi altså vente med at afgøre dette spørgsmål. Dog kan man allerede nu stille det krav, at analysen måtte inddrage den materielle totalsammenhang, d.v.s. ikke alene partiernes og organisationernes udvikling mod reformismen, men også hele den materielle produktions erfaringsbetingelser: det kunne jo være, at det for-

30. K. Schmidt: Den moderne storindustri... s. 10. 
hold, »at det store flertal blandt arbejderne i Vesteuropa... nærede urokkelige og skæbnesvangre illusioner om en »statskapitalistisk « udviklings velsignelser«, hvilket gav udfaldet, hang sammen med deres erfaringer i den materielle produktion! M. Vester ${ }^{31}$, der har foretaget grundige undersøgelser af den engelske industris og arbejderklasses udvikling i perioden 1792-1848, har kunnet konstatere en sådan sammenhæng: datidens forskellige kontrasterende »orienteringer « blev repræsenteret og udviklet af bestemte sociale grupper, således at de individuelt producerende havde en tendens til at udvikle restaurative utopier, der skulle virkeliggøres politisk, og som indebar en tilbagevenden til før-industrielle tilstande, medens kooperativt producerende grupper kunne associere sig økonomisk og udvikle industrielle utopier, der skulle virkeliggøres gennem direkte $\varnothing$ konomiske aktioner, og som indebar en bibeholdelse af den industrielle produktionsmåde, men en ændring af produktionsforholdene.

Men lad os se lidt nærmer på K. Schmidts andet argument, der går ud på, at selve den store industris kooperation, som for »flertallet « af arbejderne har betydet, at deres »produktive aktivitet er blevet reduceret til tom, abstrakt aktivitet, til et vedhæng til maskinerne, og dens sammenhæng med de andre arbejderes aktivitet er fastlagt i maskineriet, altså fremmedbestemt « - at selve denne materielle kendsgerning intet som helst har at gøre med arbejdernes afmagtsfølelse og deres resignation overfor de livsbetingelser, som klassesamfundet sætter for arbejderklassens medlemmer.

Udfra et virkelig materialistisk standpunkt er denne antagelse absurd, og må i egentlig forstand virke som en kniv i ryggen på de arbejdere, der dagligt og i årevis har erfaret vold, undertrykkelse, udbytning og fremmedgørelse i den materielle produktion, og for hvem indskrænkelsen af livsmuligheder og bevægelsesfrihed har en umiddelbar, materiel og sanseligt anskuelig evidens! Kun en venstre-intellektuel, hvis livssammenhænge overvejende ligger udenfor den materielle produktion i industrien, kan med et par pennestrøg fraskrive arbejdernes selverfaringer med arbejdet enhver betydning for deres politiske bevidsthed og praktisk-politiske engagement:

Arbejdet er ikke egnet for mennesker, kun for robotter, det er akkordarbejde og forlanger derfor mere end fysisk anstrengelse, nemlig nervemæssig anstrengelse, med andre ord:

det virker negativt på det menneskelige nervesystem. Det er morderisk arbejde, som ødelægger livet for en mand og ungdommen for de unge.

Jeg synes, at det gør en til automat, frarøver en sin personlighed, blokerer ethvert initiativ.

Jeg er blevet maskine, som en robot. Jeg arbejder ved pressen på bånd nr. 27. Dybere ned i helvedet kan jeg ikke komme.

31. M. Vester: Die Entstehung des Proletariats als Lernprocess. Frankfurt/M 1970. Se også dette arbejde s. $7 \mathrm{f}$.

V. Borg: industriarbejde og arbejderbevidsthed, s. 95. 
Modbydeligt. Min maskine har i det mindste et nummer, men jeg... ikke engang det.

Det er tilstrækkeligt med et ord: FIAT = udbytning, træthed, underkastelse.

Jeg synes, vi kun er en mekanisme i produktionens maskineri, som de lader løbe for fuld kraft, eller kun et led i produktionskæden, som de ganske enkelt udskifter, når det ikke fungerer.

I disse vurderinger af deres eget arbejde, hvad det gør ved dem, udtrykker Fiatarbejderne deres konkrete erfaringer med ufrihed, d.v.s. med indskrænkelsen af deres faktiske, fysiske bevægelsesspillerum, deres erfaringer med maskinen som noget, der dagligt udøver tryk og tvang på arbejdernes liv, som noget, der fremstår som en fremmed magt, der behersker såvel ham som de andre arbejdere og anvender dem til at producere. At langt det overvejende flertal af arbejderne nødvendigvis må gøre sådanne erfaringer bliver forståeligt, når man betænker de erfaringsbetingelser, som den strukturelle kooperation konstituerer for arbejderne. De fleste arbejdere tilbringer nemlig størstedelen af deres vågne liv på en arbejderplads, der er fast afgrænset, og som indskrænker deres bevægelsesfrihed: den enkelte arbejdsplads' arbejdsoperationen, dens såvel rumlige som tidsmæssige dimension, er vidtgående bestemt af maskinsystemet. Fabrikkens rumlige område som helhed unddrager sig dermed arbejdernes umiddelbare, anskuelige erfaringsverden (oplevelses-). Kun visse grupper såsom mestre, formænd, tillidsmænd, sikkerhedsrepræsentanter, de såkaldte »springere « eller »afløsere« ved et samlebånd, kan - og må ofte nødvendigvis - skaffe sig et overblik over fabrikkens område som helhed. Men flertallet af arbejderne er hele dagen bundet til en del af fabrikkens totalmaskineri, det fremtræder kun fragmentarisk for dem. Alene dette faktum repræsenterer en enorm blokering: da maskineriet ikke kan opleves og erfares som helhed, fremtræder det for flertallet af arbejderne som en fremmed magt, antager form af en mystificeret objektver den. »En unders $\varnothing$ gelse af de idag aktive politiske arbejdere herhjemme ville givetvis vise, at de havde specialjobs, d.v.s. passede fx. en bestemt maskine, eller var såkaldte »springere« ved et samlebånd.).

Vejen fra den ovennævnte indskrænkede erfaringsbasis til arbejdernes oplevelse af kapitalmystifikationen er ikke lang, altså til det forhold, at kapitalen i arbejdernes oplevelse fremstår som en fremmed magt, der behersker og kontrollerer dem, og ikke som et produkt af deres eget arbejde, og at arbejdets samfundsmæssige produktivkraft, kooperationens produktivitet, fremstår som kapitalens iboende kraft (produktiv-) og ikke som en kraft, der udspringer af deres egen kollektive kraft.

Heller ikke exemplerne fra den amerikanske storindustri forklarer noget som helst om flertallet af arbejdernes afmægtighed og resignation. Den kendsgerning, at der i 1919 var 3630 strejker med over 4 millioner deltagere, at der i 1922 var 1,6 millioner strejkende o.s.v. o.s.v. - alle disse strejker kan aldrig være hovedproblemet for en revolutionær bevægelse. Selvfølgelig er de vigtige at beskæftige sig med for så vidt, at arbejderbevægelsen kan uddrage erfaringer 
af sådanne på engang spontane og organiserede aktioner, erfaringer med de subjektive og objektive betingelser for kollektiv aktion. Men her kan let ske en proportionsforvrængning! At 1, 2, eller 3 millioner udbyttede arbejdere går i strejke, er hverken i strid med Borgs analyse eller burde undre nogen som helst: ikke den kendsgerning, at den udbyttede strejker eller den sultne stjæler, beh $\varnothing$ ver en særskilt forklaring, men derimod den historiske kendsgerning, at det kun var 1, 2, eller 3 millioner og ikke flertallet af de udbyttede arbejdere, der gik i strejke! Dette problem, som er den væsentligste årsag til at mange begrænsede og isolerede strejker nødvendigvis må ende med nederlag, behandles ikke ja, stilles egentlig ikke engang af K. Schmidt. Når han skal forklare »Flintstrejkens « (1936-) og hele den efterfølgende bevægelses nederlag, anfører han kun desangående, at det altovervejende flertal af amerikanske arbejdere (de militante arbejdere iberegnet) nærede »fatale illusioner om Roosevelt-administrationens statskapitalistiske tendens og hensigter- «. Men det virkelig centrale problem er jo, hvorfor masserne anså reformistiske løsninger på deres problemer som mulighed, hvorfor de foretrak dem fremfor revolutionære løsninger.

\section{Overvindelse af den dikotome bevidsthed: Arbejderkollektivet}

En realistisk vurdering af dikotomiens årsager kræver altså en inddragelse af bl.a. arbejdernes indskrænkede erfaringsbasis under den store industris fremmedbestemte eller hierakiske kooperationsform. Dette betyder selvfølgelig ikke, at arbejdernes adfærd og bevidsthed udelukkende og entydigt bestemmes af arbejdet $\mathrm{i}$ den strukturelle kooperation. En sådan antagelse ville man med rette kunne kalde en »extremt objektivistisk teori« eller »uunderbygget objektivistisk spekulation . $^{32}$ I den kapitalistiske produktionsproces opstår der også mekanismer, der tendentielt forvandler arbejdernes faktiske koncentration i produktionsprocessen til en bevidst forening og organisering blandt arbejderne. Under produktionen af den relative merværdi, som er karakteristisk for den store industri, opstår der således specifikke konflikter, som arbejderne reagerer over for ved at organisere kollektive handlinger: derved ophæver de dels den serialisering ${ }^{33}$, der udspringer af, at de uafhængigt af hinanden, når de begynder der i et forhold til samme kapital, men ikke til hinanden, når de begynder deres kooperation i arbejdsprocessen, og dels deres indskrænkede erfaringsbasis og faktiske isolation $\mathrm{i}$ den store industris fremmedbestemte kooperationsform. Enkelte arbejdergrupper som fx. vedligeholdelsesarbejdere og »springere « eller afløsere ved et samlebånd sørger for, at der bliver etableret forbindelser mellem de isolerede arbejdsenheder. Disse uformelle kontakter resulterer i etableringen af et modsystem, der i litteraturen gerne omtales som »arbejderkollektivet«. (S. Lysgård). I Lysgårds unders $\varnothing$ gelse af en norsk papirfabrik, talte arbejderne om »os arbejdere« og »be-

32. K. Schmidt: den moderne storindustri... s. 10.

33. Begrebet er præget af J. P. Sartre og betyder »en mangfoldighed af ensomheder «, hvor et fælles objekt (her kapitalisten) etablerer en ydre enhed mellem dem. 
driften «, »vi« og de »andre «, hvor bedriften blev opfattet som et system, deres eget kollektivsystem stod i modsætning til og overfor hvem de afskærmede sig og foranstaltede modforholdsregler overfor. ${ }^{34}$ Arbejdernes uformelt organiserede modsystem er ikke alene et resultat af interessemodsætningen mellem kapital og lønarbejde, men også en aktiv formidlingsinstans for samme: indenfor rammerne af det arbejdsdelte kollektiv formidler nogle af medlemmerne de kollektive erfaringer med aktioner videre til nyankomne medlemmer, andre opsporer og viderebringer oplysninger eller håndhæver kollektivets normer, mens andre igen tager initiativet til at organisere nye forholdsregler overfor ledelsen. Gennem disse problemfortolkende processer bevares, videreudvikles og videreformidles en kollektiv bevidsthed eller en fælles forståelse af arbejdernes fælles situation på virksomheden. Denne kollektive bevidsthed, der hverken kan opfattes som en slags gennemsnit af de enkelte implicerede arbejderes meninger eller behøver at existere som manifeste forestillinger hos hovedparten af arbejderne, virker vejledende på kollektivets organisering af aktioner såsom strejker, trussel om strejker og den bevidst organiserede produktionsbegrænsning, som allerede Taylor havde observeret, og som består i at arbejderne med fuldt overlæg arbejder så langsomt og lidt, som de overhovedet tør, samtidig med at de overfor de overordnede giver det udseende af, at de skam arbejder så hurtigt som overhovedet muligt, fordi de »i nitten ud af tyve industrielle virksomheder opfatter det som værende i direkte modstrid med forskellige 'autoriteter' (formænd, mestre, tillidsmænd o.s.v), bidrager igen på sin side til videreudviklingen af den kollektive bevidsthed.

Sociologiske unders $\varnothing$ gelser har altså vist, at arbejderne overskrider den passive tilstand som de nederste, som de afmægtige under en fremmed magt, ved at organisere kollektive handlinger, og at de udvikler en kollektiv bevidsthed $\mathrm{i}$ form af en »vi«-bevidsthed, der gør det muligt for dem at forstå sig selv som del af arbejdergruppen indenfor virksomheden som helhed. Basis for den kollektive bevidsthed er en præstationsbevidsthed, der selv nødvendigvis er forbundet med den kollektive selvbevidsthed, da den enkelte arbejders præstation kun får betydning som en del af arbejdergruppen som helhed, når den skal sammenlignes med kapitalens magt: den enkeltes præstation som øltapper eller specialarbejder kan som sådan til enhver tid udskiftes og undværes, hans selvbevidsthed som arbejder bliver med andre ord først samfundsmæssigt betydningsfuld, hvis den indbefatter en selvforståelse som del af arbejdergruppen som helhed. En sådan kollektiv prastationsbevidsthed, der indeholdt forestillinger om, dels hvad arbejde egentlig var for noget, og dels nogle produktivitets- og prioritetsforestillinger, har bl.a. Popitz o.a. kunnet konstatere:

Arbejderne har noget at tilbyde, som i det mindste er kapitalen - den 'døde' kapital - jævnbyrdigt, om ikke endda overlegen, nemlig arbejdet - det 'menneskelige arbejde'. Det opfattes som legemligt arbejde, d.v.s. omfatter den 
del af den menneskelige virksomhed, der mest øjensynligt er arbejde, endvidere opfattes det som produktivt arbejde, d.v.s. en umiddelbart værdiskabende præstation; og endelig som primært arbejde, d.v.s. en funktion, der skaber de fundamentale forudsætninger for de andres, samfundets, existens. ${ }^{35}$

Den kollektive bevidsthed har således sine rødder i arbejdernes stilling i den samfundsmæssige produktionsproces. Selve det faktum, at alle arbejdere under den store industris fremmedbestemte kooperationsform indtager positioner nederst i hierakiet og overvejende udøver rent udførende, manuelt arbejde, gør det muligt for dem, at afgrænse og distancere sig fra andre grupper, fra »alle dem over formanden, dem med rene hænder og ren flip«, fra »dem deroppe, der ikke arbejder « ${ }^{36}$, og endvidere at opfatte sig som et kollektiv, der udmærker sig kvalitativt i forhold til de andre. Af afgørende betydning for arbejdernes kollektive selvvurdering er endvidere deres ringe chancer for at forbedre deres sociale status. Selv om enkelte har mulighed for at blive formænd og mestre fx.; bliver det dog hurtigt klart for de fleste, at de ikke kan uddrage sig arbejdertilværelsens trøstesløshed gennem individuel opstigning, da antallet af sådanne positioner er yderst begrænset i forhold til mulige ansøgere, samtidig med, at en overgang fra arbejder til formand af de andre arbejdere opfattes som en overgang fra »vi arbejdere « til »de andre«:

Jeg kendte jo alle på de forskellige afdelinger fra før, men siden jeg blev formand og gik rundt, så stoppede de samtalen og slukkede røgen - fordi de vidste, hvor de havde mig. ${ }^{37}$

Der existerer således forhold og mekanismer i virksomhederne, der tenderer mod en forening og organisering blandt arbejderne, og mod udviklingen af en kollektiv bevidsthed, der kan virke vejledende på kollektivets organisering af aktioner overfor virksomhedsledelsen. Spørgsmålet er imidlertid, om de daglige konflikter i virksomheden kan blive et tilstrækkeligt grundlag for en langsigtet læreproces, gennem hvilken arbejderne kan opnå erkendelse af deres egen fælles styrke, altså overvinde den resignerede bevidsthed om en uforanderlig tilstand. Det mener fx. Elmar Altvater:

De daglige klassekampe, der ytrer sig i lønkonflikter, konflikter omkring arbejdsintensiteten, afskedigelser, manglende sikkerhedsbestemmelser, kampen mod utålelige arbejdsbetingelser o.s.v., interpreteres godt nok udfra det dikotomiske begreb om virksomhedsforholdene, men formår tendentielt at transformere denne bevidsthed til en klassebevidsthed, da modsætningen mellem lønarbejde og kapital er potentielt indeholdt i dikotomien. ${ }^{38}$

Og ligeledes V. Borg:

35. H. Popitz o.a.: Das Gesellschaftsbild des Arbeiters. Tübingen 1957, s. 239.

36. S. Lysgård: Arbejderkollektivet, s. 28ff.

37. Ibid., s. 35.

38. E. Altvater: Produktive und unproduktive Arbeit als Kampfbegriffe, i: Sozialistische Politik nr. 8, sept. 1970, s. 62. 
Den dikotome, resignerede bevidsthed kan kun overvindes, ved at arbejderne gennem de daglige konflikter i virksomheden opnår erkendelsen af deres egen fællesstyrke og af, at kapitalen og »dem der oppe « ikke er en uovervindelig magt, men en magt, der er udtryk for deres egne transformerede kræfter, og derfor for deres egen magtesløshed..$^{39}$ I selve etableringen af en modmagt (arbejderkollektiv m.a.) mod kapitalens magt, ligger der kim til erkendelse af, at den produktive kraft, der fremtræder som kapitalens produktive kraft, i virkeligheden er deres egen kollektive kraft i fordrejet form. Ved at blive tvunget til at kontrollere deres produktive aktivitet bliver det muligt, at arbejderne kan opfatte sig selv som den klasse, der har den potentielle magt i samfundet. ${ }^{40} \mathrm{Ar}$ bejderkollektiver er grundenheden i klassekampen mellem kapitalistklassen. Ved at organisere kollektive handlinger kan arbejderne overskride den passive tilstand som de nederste, som de afmægtige under en fremmed magt. ${ }^{41}$

Som hovedårsag til, at denne overskridelse endnu ikke er sket i sin fulde udstrækning, anfører Borg fagforeningens konfliktforebyggende virksomhed overfor den daglige klassekamp i virksomhederne, som er en konsekvens af den centrale klassekonflikts institutionalisering i dette århundrede. Herhjemme kender vi fænomenet i form af en arbejdsmarkedets grundlov (Septemberforliget og Hovedaftalen), der indeholder regler om kollektive overenskomster, regler om fredspligt, en stadfæstelse af arbejdskøberens ret til at lede og fordele arbejdet, og hele det arbejdsretslige system, der er opbygget omkring Hovedaftalen, og som fastlægger arbejdskonflikters art (retskonflikter versus interessekonflikter) og regler for behandlingen af konflikter (faglig voldgiftsret og arbejdsretten). Denne institutionalisering har i praxis bevirket, at arbejderne gennem mange år er blevet forhindret i at gøre erfaringer ved selvvirksomhed, selvkontrol og selvforvaltning. Herved er der sket dels en »opløsning « af den historiske bevidsthed, idet de erhvervede rettigheder ikke længere erkendes som resultater af stadigt nye kampsituationer: der opstår da let en illusion blandt arbejderne om, at deres nuværende magtpositioner er sikrede. Endvidere holdes de fast i objektrollen i og med, at de for dem vigtigste afgørelser mere og mere bliver resultater af forhandlinger uden forudgående kampforholdsregler: derved hindres de i at gøre selverfaringer med de subjektive og objektive betingelser for kollektiv handlen.

Selvom man ikke kan underkende betydningen af disse forhold for arbejdernes frigørelsesinteresser, er det imidlertid et spørgsmål, om der ikke i hele denne opfattelse ligger en overbetoning af arbejderkollektivets betydning. Allerede begrebet 'kollektivsystem' er vildledende. Ligeledes begrebet 'modmagt'. R. Dahrendorf har gjort opmærksom på, at talen om en uformel organisation eller selvstændig modmagt i virksomheden er vildledende, for så vidt der ikke altid og

39. V. Borg: Industriarbejde og arbejderbevidsthed, s. $28 \mathrm{ff}$.

40. Ibid., s. $78 f$.

41. Ibid., s. 79 . 
i alle virksomhedsafdelinger etableres sådanne grupperinger, at der altid er tale om enkelte gruppedannelser, der nok kan stå i en indbyrdes forbindelse i kraft af de såkaldte »nøglepersoner «, der er medlemmer af flere grupper, men som kun undtagelsesvis danner en fast struktur, der omfatter virksomheden i sin helhed:

Uformelle grupper går gennem hele virksomheden som et uregelmæssigt, men tæt netværk. Visse unders $\emptyset$ gelser har vist, at dette net forbinder ethvert medlem med alle andre medlemmer i virksomheden, selvom det er på en højst middelbar og uoverskuelig måde... Til trods for dette netværk af uformelle grupper, ville det ikke desto mindre være forkert, at tale om en uformel organisation i virksomheden, da der ikke her er tale om et rationelt koordineret system. ${ }^{42}$

De uformelle gruppedannelser forbliver altså som helhed uorganiseret. Spørgsmålet om, hvordan de relativt isolerede gruppedannelser i virksomheden så evt. kan sammenføjes til en effektiv og selvstændig arbejdermodmagt, stilles ikke, hverken af E. Altvater eller V. Borg. Begge antager stiltiende, at den daglige klassekamp på virksomhederne er en, ikke alene nødvendig, men også tilstrækkelig læremester for arbejderne: for sidstnævnte er det - foruden den strukturelle kooperation - kun masseorganisationernes og partiernes burokratiske stivnen og kontrolleren af arbejdernes selvvirksomhed på de enkelte virksomheder, der hæmmer en sådan læreproces. Men dermed kommer man let til overfladiske og ufuldstændige synspunkter angående såvel dikotomiens årsager som betingelserne for dennes ophævelse. For nok er enhver arbejder medlem af et eller flere fællesskaber indenfor virksomheden, men han er samtidig et led $\mathrm{i}$ virksomhedseksterne kollektiver såsom fagforeningen, arbejderklassen, hvortil kommer, at han ikke kan unddrage sig indflydelsen fra hele samfundsformationen og andre klasser. Det er således K. Schmidts fortjeneste at have fremhævet betydningen af klassekampen mellem bourgeoisiet og proletariatet, der som en samfundsmæssig proces går tværs gennem arbejderne i de enkelte virksomheder, også i de tilfælde, hvor de samfundsmæssige kræfter står overfor hinanden som fronter i en politisk kamp eller i en borgerkrig. Dertil kommer arbejderens erfaringer indenfor den moderne kernefamilies »terrorsammenhæng « (Reiche), erfaringerne i skolen og effekten af massemediernes ideologiproduktion gennem mange år. Den dikotome bevidsthed, som al anden bevidsthed, må betragtes som et resultat af mange komponenter, dens produktion sker samfundsmæssigt - over virkelighedens genstandsmæssige former, historien, socialiseringen, drifts $\emptyset$ konomien, personens psykiske opbygning, opdragelsen og de umiddelbare erfaringer i produktionsprocessen - og alle disse niveauers tilbage- og vekselvirkninger: bevidsthed kan aldrig være andet end den bevidste væren, og menneskets væren er deres virkelige livsproces (Marx), der hverken kan indsnævres til erfaringer med historiske opgør mellem bourgoisieklassen og arbejderklassen

42. R. Dahrendorf: Sozialstruktur des Betriebes. Wiesbaden 1959, s. 39. Se også L. v. Friedeburg: Soziologie des Betriebsklimas, Frankfurt/M 1963, s. 9. 
eller erfaringer med de daglige klassekampe i virksomhederne, men strækker sig lige fra de forskellige trin i produktionen af arbejdskraftens vare- og brugsværdiegenskaber (socialiseringen og personens psykiske opbygning i familien og skolen, tilegnelsen af arbejdsviden, fritiden og massemedierne) til dennes indsats og umiddelbare erfaringer i produktionsprocessen. ${ }^{43}$

\section{Automationen og de vilde strejker}

Lad os til sidst se på, hvorvidt automatiseringen i industrien skaber forudsætningerne for at overvinde den resignerede bevidsthed om en uforanderlig tilstand. V. Borg når i sine analyser af den nye arbejderklasse frem til, at automationen i sektorer indenfor den kemiske industri, olieindustrien og den elektroniske industri ikke medfører en ændring i arbejdernes adfærd og bevidsthed, men snarere konstituerer en objektiv mulighed for en sådan.

Det specifikke og nye ved automationen er, at de nye kooperationsformer tendentielt ophæver storindustriens fremmedbestemte kooperations extreme arbejdsdeling mellem planlægning/kontrolfunktioner, varetaget af teknikere og ingeniører, og de rent udførende funktioner, varetaget af specialarbejderen. Medens forholdet mellem de to lønarbejdergrupper i den store industris kooperation er hierarkisk, og der derfor ikke vil være mange muligheder for, at der udvikles en fælles bevægelse mellem dem, vil de nye kooperationsformer, hvor andelen af højtkvalificerede (ingeniører, teknikere) er stor, ændre dette forhold: forholdet bliver tendentielt ikke længere hierarkisk men bygger snarere på de to lønarbejdergruppers falles, lige og selvstændige kooperation. Denne ændring af forholdet er teknologisk betinget, og en sådan fælles, lige kooperation virkeligg $\varnothing \mathrm{r}$ først fuldt ud de nye kraftpotenser, der allerede dynamisk er indeholdt $\mathrm{i}$ det samfundsmæssige arbejde. Imidlertid vil en sådan udvikling komme i modstrid med direktionernes og koncernledelsernes interesse $i$ at opretholde den hierarkiske og fremmedbestemte kooperationsform, med koncernledelsernes magtinteresse $\mathrm{i}$ at bevare produktionsprocessen som middel i den kapitalistiske merværdiproduktion. De uundgåelige modsætninger »mellem arbejdernes selvbevidsthed som kollektive regulatorer og organisatorer af produktionen og deres ydre forening gennem kapitalen, gennem den kapitalistiske vareproduktion og de hierarkiske koncernledelser «, i modsætningerne »mellem arbejdernes stadigt stigende magt og ansvar i selve arbejdsprocessen og deres sociale underkastelse under de stadigt mere centraliserede koncernledelser « hvis manglende formåen til at organisere produktionen på en effektiv måde bliver åbenbar for stadig flere lønarbej dergrupper, - disse modsætninger danner udgangspunktet for kollektive læreprocesser, i de to lønarbejdergrupper: ${ }^{44}$

1. Hvad angår de højtkvalificerede lønarbejdergrupper, vil den længerevarende, kollektive læreproces' grundlag være dels det forhold, at de begynder at ind-

43. O. Negt/A. Kluge: Öffentlichkeit und Erfahrung... s. $410 \mathrm{ff}$.

44. V. Borg: Industriarbejde og arbejderbevidsthed, s. 136. 
gå i en lige og selvstændig kooperation med andre lønarbejdergrupper, og dels det forhold, at de, mere eller mindre i de forskellige lande, har været i stand til at lade sig integrere i hele arbejderbevægelsen og har kunnet udforme deres krav i forbindelse med de $\varnothing$ vrige lønarbejdergrupper. Dette har især været tilfældet i Frankrig, og har givet sig udtryk i deres stadig øgede deltagelse i arbejdskonflikter. Men denne udvikling vil ikke forløbe som en kontinuerlig-progressiv proces, da mange stadig vil være præget af statustænkning og eliteforestillinger..$^{45}$

2. Hvad angår de mindre kvalificerede arbejdere, vil grundlaget i den kollektive læreproces ligeledes være det forhold, at de indgår i en lige og selvstændig kooperation med de højtkvalificerede grupper. Hæmmende momenter vil være den dikotome bevidsthed, hvor alle, der har en højere uddannelse og en højere løn, betragtes med mistillid og som medlemmer af en anden klasse end én selv. ${ }^{46}$

Men de kollektive læreprocesser kan kun ske i forbindelse med lønarbejdernes fælles kamp, og det er denne, der er mediet for udviklingen af en »ny arbejderbevidsthed $\ll$ :

Denne fælles kamp har medført en voksende erkendelse af, at kampen må føres på grundlag af lønarbejdernes deltagelse i produktionsprocessen, ved systematiske forstyrrelser af kooperationsprocessen. En sådan aktionsform forudsætter et dybtgående kendskab til deres egen stilling i den. Denne voksende erkendelse har bevirket, at lønarbejderne under de mest fremskredne kooperationsformer er begyndt at forholde sig bevidst til kooperationen som deres egen produktivkraft og betragte deres produktive aktivitet som potentielt fri skabende aktivitet, hvis udviklingen hæmmes af de kapitalistiske produktionsforhold, hvor produktivkræfternes udvikling beherskes af kapitalens forøgelsesinteresser. ${ }^{47}$

En sådan bevidsthed om egne produktive kræfter, må altså betragtes som et resultat af en længerevarende, kollektiv læreproces i tilknytning til fælles kampe, og den er en nødvendig forudsætning for producenternes virkelige - i modsætning til statssocialismens tilsyneladende - overtagelse af kontrollen over produktionen og dens fordeling, d.v.s. for en tilfredsstillelse af deres virkelige samfundsmæssige behov for gennem solidarisk kommunikation at disponere over såvel arbejdsbetingelserne som arbejdsprodukterne. En sådan bevidsthed kan ikke importeres ude fra, men må udvikles gennem selverfaringer i forbindelse med kollektive aktioner, der tager sit udgangspunkt i producenternes umiddelbare interesser. I denne forbindelse indtager de vilde strejker en særstilling, da arbejderne i tilfælde af strejker realiserer den eneste fordel, de har overfor besidderne af produktionsmidlerne, nemlig deres antal: under en strejke skaber de en ny samfundsmæssig magtfaktor, en kvantitativ og kvalitativ ny arbejdermodmagt.

45. Ibid., s. 137.

46. Ibid., s. 138.

47. Ibid., s. 137. 
Spørgsmålet er nu: hvilke muligheder for bevidsthedsændringer, som resultat af en indlæringsproces, giver nu en sådan kollektiv aktion? Hvordan varierer disse muligheder med strejkens indhold og form? Spørgsmålet kan ikke her besvares med en omfattende analyse af alle strejkebevægelser, men snarere antydes.

En strejke forudsætter et minimum af solidaritet og organisering: Den valgte kampform (strejken) kan betragtes som udtryk for den hidtil opnåede solidaritet blandt de deltagende, deres politiske bevidsthed og deres selvbevidsthed. Indlæringsmulighederne synes nu først og fremmest at afhænge af, hvorvidt det lykkes for strejkebevægelsen at etablere en virkelig selvorganisation (hvilket ikke indebærer, at den sker uafhængig af fagforeningen, men blot, at den ikke hæmmes eller »stækkes « af samme). Især i Italien og Frankrig, har arbejderne - i modsætning til Danmark og Tyskland - demonstreret, at de har udviklet en høj grad af selvorganisation.$^{48}$ En hyppigt valgt kamporganisationsform fra de strejkendes side var »strejke-komité-strukturen«, hvor strejkelederne vælges direkte af og blandt strejkedeltagerne (såvel dem med som uden 'fagforeningsbog' og 'partitegn'), som er direkte ansvarlige og til enhver tid afsættelige, hvis de kommer i strid med flertallet, som hyppigt indkalder alle medlemmer til suveræne forsamlinger, der orienteres om, tager stilling til og træffer beslutninger angående kampens hidtidige og fremtidige midler og deres anvendelse. Mandel ${ }^{49}$ har bl.a. påpeget en sådan demokratisk organisationsforms muligheder for at sætte virkelige frigørelsesprocesser i gang blandt strejkedeltagerne. Organisationsformen begynder

at befri den enkelte arbejder fra den længe vante passivitet og underordning i produktionen. Den befrier ham fra trykket fra forskellige 'autoriteter', der undertrykker ham i hans daglige liv. Fra at være et objekt, der er bestemt og undertrykt af det økonomiske og samfundsmæssige system, af kapitalen, 'markedslovene', maskinerne, mestre og formænd, bliver arbejderen til et selvbestemmende subjekt. Derfor har opmærksomme iagttagere af nutidens store strejker da også konstateret en følelse af frihed og elementær 'livsglæde', der ledsager dem. ${ }^{50}$

I og med at strejkerne ophæver de daglige fremmedgørelsesmekanismer, som Mandel nævner (og som kan suppleres med de fremmedgørelsesmekanismer, der kan konstateres i forholdet: fagforeningsstop og medlemsbasis, og de, som udgår fra den borgerlige offentlighed: massemediernes informationer og interpretationer), - i og med at arbejderen befries for objektrollen, vil han få lejlighed til at erfare sig selv og de andre som selvbestemmende subjekter, der selv organiserer deres egne kampmidler overfor modpartens kræfter, etablerer selvstændige organisationer og kommunikationsstrukturer (medier): Den demokratiske forberedelse af aktioner, den fysiske deltagelse i disse aktioner og i de deraf resulterende konflikter med bl.a. 'autoriteter' (hierarkiets foresatte,

48. Ibid., s. 99.

49. E. Mandel (udg.): Arbeiterkontrolle. Arbeiterräte. Arbeiterselbstverwaltung. Frankfurt/M, 1971, 50. Ibid., s. 14. 
fagforeningsmedlemmer: tillidsmænd etc.; den efterfølgende forarbejdning af erfaringer og deres indordning større politiske, samfundsmæssige og historiske sammenhænge - al denne autonome aktivitet åbner mulighed for, at de strejkende erkender eller indser, at nogle af de sociale fænomener, som de førhen har anset for at være uforanderlige lovmæssigheder eller uafvendelige betingelser, i virkeligheden blot er ideologisk fixerede, men i princippet foranderlige forhold. Denne forventning er rimelig udfra den betragtning, at ideologiers gyldighed beror på en systematisk indskrænkelse af den menings- og viljedannende kommunikation, hvor den demokratiske kamporganisationsform jo netop udvider den enkeltes muligheder for at handle og kommunikere. Endvidere ville man kunne forvente en gradvis nedbrydning af de såkaldte kommunikationsbarrierer, en udvidelse af arbejderens sproglige udtryksformåen, i og med at hans muligheder for at handle ændres og visse ideologier mister deres legitimitet.

Men enhver vild strejke har sine begrænsninger i det faktum, at masseaktioner nødvendigvis må være diskontinuerlige og kortvarige. Sålænge det ikke lykkes for arbejderklassen som helhed at forandre den kapitalistiske produktionsmåde, sålænge aktionen forbliver »lokal« og »punktuel«, vil »enhver masseaktion finde sin tidsmæssige grænse $i$ arbejderens $\varnothing$ konomiske, fysiske og åndelige modstandskraft overfor lønfrafald $\ll .{ }^{51}$ At benægte dette ville være ensbetydende med at underkende betydningen af de materielle existensbetingelser, som hver enkelt arbejder er underkastet under de nuværende produktionsforhold.

I sammenhæng hermed står det faktum, at de vilde strejker indtil videre (i Danmark, Tyskland) ikke har kunnet antage en totalsamfundsmæssig karakter, ved at kravene udvikler sig fra lokale lønkrav, krav om nedsættelse af arbejdstempo, ophør af skifteholdsarbejde o.l., til krav, der vedrører arbejderklassens (samfundets) interesser som helhed. På den ene side er de traditionelle arbejderorganisationer ophørt med at fungere som medium for en sådan politisk transformering af lokale krav: siden de har involveret sig i et klassesamarbejde, har de i stigende grad - og indtil nu med held - forsøgt at kontrollere sådanne aktioner, gøre dem kortest mulige og forhindre kravene i at udvikle sig. ${ }^{52}$ På den anden side bevirker de vilde strejkers kortvarighed, at der ikke udvikles et nyt medium for en sådan transformering: en organisation, kommunikation o.l., der kan fungere som et kontinuerligt, vedvarende element, og som er forankret i og videreforarbejder de strejkendes kollektive erfaringer. Forskellige venstregruppers fors $\emptyset \mathrm{g}$ på at foretage denne transformering for arbejderen (gennem udgivelse af fx. et fabriksblad, paroler, oprettelse af organisationer og fonds) er dømt til at mislykkes, for så vidt arbejderne selv må praktisere disse sammenhænge, for derigennem at gøre selv-erfaringer. Kun de erfaringer, som arbejderne selv har gjort, er konsekvensrige for arbejderklassens befrielseskamp.

51. E. Mandel: Lenin und das Problem des proletarischen Klassenbewusstseins, i: Lenin: Revolution und Politik. Suhrkamp Verlag 1970, s. 162.

52. V. Borg: Industriarbejde og arbejderbevidsthed, s. 98f. 
De vilde strejkers begrænsede, lokale og kortvarige karakter bevirker, at de får begrænsede muligheder for at resultere i stabile bevidsthedsændringer: medens enkelte arbejdere fortsætter kampen med andre midler mellem to perioder med kampaktioner, vil flertallet af arbejderne kun være aktive under selve de kortvarige kampe, men i hele den mellemliggende periode tvinges ind i en objektrolle igen. Det er derfor usandsynligt, at umiddelbare erfaringer med strejker uden videre fører til stabile socialistiske indstillinger og en situationsuafhængig klassebevidsthed. De (erfaringer) behøver et erfaringsdannende medium (organisation, interaktionsform, arbejderoplysning o.l.), hvorigennem de umiddelbare erfaringer med klassekonflikter kan formidles til langsigtede læreprocesser (kollektive).

Det viser bl.a. også erfaringerne fra de mange klassekampe i Italien siden 1968. De har ikke alene deres grundlag i industriproletariatets utilfredshed med dens forringede livssituation, som var et resultat af kapitalens $\varnothing$ gede udbytning ved intensivering af arbejdet, og som for arbejderne konkretiserede sig umiddelbart i form af større arbejdsbelastninger, men også i den italienske arbejderbevægelses specifikke historie og struktur. Dels havde det italienske metalforbund allerede i begyndelsen af 1960'erne indledt en intern »kulturrevolution«, der opløste de stivnede strukturer og dermed skabte de organisatoriske forudsætninger for basis-aktiviteter, og dels var der i fagforeningerne bestræbelser igang med at udvikle klassebevidste kadrer i virksomhederne, som var i stand til at opfange det voksende utilfredshedspotentiale i basis og transformere dette i kollektive politiske aktioner. Det var først og fremmest disse grupper af overvejende industrielle fagarbejdere, der traf de første beslutninger angående kampe og som begyndte strejkerne i 1969:

Den nye strejkefase (hos FIAT) bliver ikke udløst spontant af de mindre kvalificerede arbejdere, der fornylig var immigrerede fra syd. Tværtimod, gnisten kom fra en af de mest kvalificerede sektorer - den Zweigwerken von Mirafiori, 8000 arbejdere, der næsten alle var værktøjsmagere og motorkontrollører -, og er et resultat af en af fagforeningen gennem mange år forberedt konflikt. ${ }^{53}$

Først i kampens videre forløb blev arbejdermassen bevægelsens bærer, frigjorde sig fra kadrene, skabte egne organisationsinstrumenter og radikaliserede og forlængede konflikten.

Det rejser spørgsmålet, om det er muligt i Danmark at udvikle sådanne kadrer i virksomhederne, som ville være i stand til at artikulere arbejdernes behov, og som i arbejdskampe ville kunne udgøre en såvel »teoretisk « funderet som organisatorisk støtte, hvilket er afgørende for sådanne kampes heldige udfald. Vi vil her indskrænke os til at omtale og diskutere eet væsentligt element i en

53. L. Castellina: Bericht über FIAT, i: Rotbuch 23, s. 92, her citeret fra H. Kern/M. Schumann: Zum politischen Verhaltenspotential der Arbeiterklasse, i: K. Meschkat und O. Negt: Gesellschaftsstrukturen. Suhrkamp Verlag 1973, s. 148. 
sådan strategi, nemlig den fabriksnære arbejderoplysning, der må opfattes som een blandt flere mulige ansatser, der alle - ifølge egen forståelse - er rettet mod udvikling af industriarbejderens politiske bevidsthed og klassebevidsthed: andre er den fabriksnære fagforeningspolitik, nedbrydning af buerokratiske strukturer i fagforeninger, der åbner for basisaktiviteter, politisk agitation gennem arbejderblade og arbejdersange, politiske aktioner o.1...

\section{Den fabriksnære arbejderoplysning: målsætning og funktion}

I de senere år har A. Brock, Negt o.a. udviklet en med henblik på praxis konciperet, konfliktorienteret og fabriksnær arbejderoplysning, der udtrykkelig knytter an til sammenhængen mellem den kollektive direkte akton og bevidsthedsudviklingen. ${ }^{54}$ Det fabriksnære uddannelsesarbejde skal ifølge sit program give arbejderen mulighed for at skaffe sig informationer og interpretationer og indøve »sociologisk fantasi«, d.v.s. lære deltagerne en tænkemåde, der gør det muligt for dem at forstå sammenhængen mellem deres individuelle skæbner og den samfundsmæssige udvikling. Ved at tage sit indholdsmæssige udgangspunkt i de konflikter, der primært er betingede af arbejderens arbejdspladsposition og de deraf resulterende tioner, skal uddannelsesarbejdet udvikle hans forståelse for, 1) at de bestående forhold kan forandres, 2) at herredømme og disciplin i fabrikken ikke kun anvendes til at forøge produktionen, men også til at undertrykke, udbytte og afpolitisere arbejderen, og 3) at lønnen som disciplineringsmiddel står i kontrast til de herskendes, store »spild « ${ }^{55}$. Når arbejderne erkender, at disse modsætningers ophævelse ikke fører til ny afhængighed, men derimod selvbestemmelse i fabrikken og samfundet i $\varnothing$ vrigt, er der chancer for, at de vil engagere sig politisk og aktivt arbejde for en fjernelse af disse åbenbare modsætninger.

Begrebet sociologisk fantasi eller sociologisk toenkemåde, har Negt o.a. overtaget fra C. W. Mills ${ }^{56}$. Sidstnævnte går ud fra, at det i »denne kendsgerningernes tidsalder « ofte er informationer, der behersker menneskenes opmærksomhed: de er ikke længere i stand til at forarbejde dem meningsfuldt. Det mennesker idag har brug for, og de har ifølge Mills også selv en fornemmelse af dette, er »en åndelig formåen, som hjælper dem til at bruge informationer og til at udvikle en fornuftig, klar oversigt over, hvad der foregår i verden, og hvad der foregår i dem selv $\ll{ }^{57}$ En sådan egenskab forventer han sig af den sociologiske tænkemåde, som han selv har beskrevet som »evnen til at skifte fra eet perspektiv til et andet, fra det politiske til det psykologiske, fra unders $\varnothing$ gelse af en enkelt familie til en sammenlignende vurdering af hele verdens nationalbudgetter « - og til at erkende strukturelle sammenhænge mellem individuel livshistorie, umiddelbare interesser, ønsker, håb og historiske begivenheder.

54. O. Negt: Soziologische Phantasie und exemplarisches Lernen. Frankfurt/M 1971. Brock o.a.: Themenkreis Betrieb bd. I-IV. Frankfurt/M. 1969.

55. Brock o.a.: Industriarbeit und Herrschaft. Frankfurt/M 1969, s. 5 f.

56. C. W. Mills: The sociological Imagination. Penguin Books 1970, s. II.

57. Ibid., s. II. 
Han konkretiserer dette ved at angive tre centrale problemstillinger, som må stå i centrum i en sådan tænkning:

1. Hvordan er dette bestemte samfunds struktur betragtet som helhed? Hvad er dens væsentlige komponenter, og hvorledes forholder de sig til hinanden? Hvorledes adskiller denne sig fra andre former for samfundsorden? Hvilken betydning har dens enkelte dele for stabilitet og ændring?

2. Hvilken position indtager dette bestemte samfund i historien? Hvilke mekanismer forandrer det (samfundet)? Hvilken position og hvilken betydning har det i udviklingen af hele menneskeslægten? Hvordan påvirker de enkelte dele, som vi undersøger, historiens udvikling, og hvorledes påvirkes de igen af denne (historie)? Hvad er denne periodes væsentlige sagsforhold? Hvorvidt adskiller den sig fra andre perioder? Hvad er specifikt for denne periodes bidrag til den historiske proces?

3. Hvad slags mænd og kvinder hersker i dette samfund og i denne periode? Hvem vil i fremtiden sætte sig igennem? På hvilken måde udvælges og formes de, befries og undertrykkes, sensitiveres og afstumpes de? Hvilken slags »menneskelig natur « åbenbarer sig i de adfærdsmåder og karakterer, som vi kan iagttage i dette samfund og i denne epoke? ${ }^{58}$

Hensigten med denne omtale af Mills har udelukkende været at angive, hvad der menes, når der tales om sociologisk tænkemåde eller en formåen til at tænke i politisk-samfundsmæssige sammenhænge. Det betyder, at hvert enkelt fænomen ses i sin samfundsmæssige sammenhæng, at ethvert tema og enhver konflikt altid ses i sin psykologiske, sociale, politiske, retslige, $\varnothing$ konomiske og historiske dimension. Kun gennem anvendelse af en sådan tænkemåde, er der håb om, at arbejderen lærer at overskride den umiddelbart fremtrædende situation, vinder indsigt i mere omfattende sammenhænge og dermed gennembryder den umiddelbare erfaringsverdens snævre perspektiv: at han formår at se de daglige oplevelser, erfaringer med konflikter omkring lønnen, sikkerhedsforanstaltningerne, arbejdsintensiteten o.s.v. i en samfundsmæssig sammenhæng, så de ikke længere anskues som private og individuelle, men derimod som nødvendige konsekvenser af den forfatning og de betingelser, som en kapitalistisk fabrik stiller ham overfor, og at såvel forfatningen som betingelserne selv blot er udtryk for de samfundsmæssige, $\varnothing$ konomiske og politiske strukturer. ${ }^{59} \mathrm{I}$ den tidligere omtalte unders $\varnothing$ gelse af Popitz o.a. var det kun type 5 og 6 (4\%), der fastlagde sammenhængene mellem den lille og store verden udfra en teoretisk grundmodel, og for hvem det lykkedes, at se sammenhænge mellem den umiddelbart fremtrædende situation i fabrikken og de samfundsmæssige, $\varnothing$ konomiske, og politiske forhold.

Som organisatorisk basis har dette uddannelsesprogram først og fremmest fagforeningernes tillidsmænd og uformelle grupper i virksomhederne. Dette

58. Ibid., s. 43f.

59. A. Brock o.a.: Industriearbeit und Herrschaft, s. 120. 
er et af de prekære punkter. På den ene side forudsætter den politiske arbejderoplysning, og er samtidig produkt af, en offensiv fagforeningsstrategi, der gennem kampforholdsregler stadigt udvider områderne for arbejdernes organiserede selvvirksomhed, kontrol og selvforvaltning, men på den anden side fremhævede vi tidligere, at fagforeninger siden accept af klassesamarbejdet, i stigende grad har fors $\varnothing \mathrm{gt}$ at kontrollere basisaktioner. Denne modsigelse kan i dag kun løses ved at støtte sig til »progressive« tendenser indenfor fagforeningen, da den dag idag de fleste arbejdere har bundet deres loyalitet til fagforeningerne. Derfor gælder Lenins argument stadig:

De (arbejderne, m.a.) må selv i praxis erkende, at de revisionistiske ledere forråder deres klasseinteresser i og med deres faktiske adfærd. Den rigtige teoretiske indsigt, at en institution eller organisation (som fx. parlamentet, fagforeningen, partier) er historisk forældet, udsiger kun lidt om, hvorvidt de også er forældede for massernes praktiske erfaringer. Sålænge masserne anser reformistiske løsninger på deres problemer som en mulighed, vil de foretrække disse fremfor revolutionære løsninger, der er forbundne med risici. De må selv erkende, at reformismen er forbundet med en større risiko først da vil de beslutte sig for det revolutionære alternativ. ${ }^{60}$

Et andet diskutabelt punkt er begrebet sociologisk tænkemåde. Intelligensens arbejdsmåde er idag det eneste middel vi kender, som kan ophæve den illusionære sammenhæng mellem arbejderens objektive situation og hans bevidsthed om samme: netop intelligensens abstraktionsformåen er et instrument, der muliggør indsigt i de fremmedgjorte sociale forhold. Men begreber som 'komplexitet', 'vekselvirkning', 'totalitet' o.l., som anvendes af arbejderbevægelsens store teoretikere, er ikke proletariatets begrebsformer, men intelligensens. Ligeledes det akademiske sprog, der gengiver intelligensens erfaringer, men ikke uden videre proletariatets. Dette forhold, der har sit grundlag i dels den for intelligensen typiske middelklassesocialisering og dels den samfundsmæssige arbejdsdeling mellem manuelt og intellektuelt arbejde, bevirker, at intelligensens arbejdsmåde ikke uden videre er en hjælp for arbejderen. Den ville kun være det, hvis den transformeredes kollektivt og etablerede sig påny $\mathrm{i}$ arbejdernes erfaringssammenhæng.

60. O. Negt/A. Kluge: Öffentlichkeit und Erfahrung, s. 336. 


\section{Den moderne storindustri og arbejderbevægelsens krise}

\section{Antikritik}

\section{Kjeld Schmidt}

Med sin lange artikel i dette nummer af Kurasje bibringer Sigurd Jensen ikke diskussionen om sammenhængen mellem den moderne storindustris opkomst og arbejderbevægelsens krise nye aspekter, endsige nye argumenter. Det lykkes ham derimod effektivt at forplumre hele den hidtidige diskussion, forvrænge problemstillingen, tilsløre den virkelige uenighed, opstille kunstig uenighed, fejlreferere de hidtidige indlæg i diskussionen, blande argumenterne sammen til en uigennemsigtig grød, modsige sig selv fra sætning til sætning og i det hele taget kvæle diskussionen under en tung dyne af sludder og vrøvl. Hans »indlæng i diskussionen « gør det derfor påkrævet at bruge en del plads på noget så kedsommeligt som berigtigelser af misforståelser, fejlreferater o.s.v. - blot for at forhindre, at hele diskussionen går i fisk. Hvad hans indlæg derudover giver anledning til af præciseringer, videreudviklinger o.s.v. er yderst sparsomt. Det er dog mit håb, at de præciseringer, videreudviklinger o.s.v., som denne antikritik vitterlig indeholder, vil bidrage til en yderligere svækkelse af den objektivistiske teori om arbejderbevægelsens krise og således anspore flere til at beskæftige sig indgående med arbejderbevægelsens historie for gennem dette arbejde at medvirke til at forklare, hvorledes arbejderklassen er havnet i den situation, den i dag befinder sig i.

\section{Rekapitulation: Borg's tese}

Udgangspunktet for hele diskussionen er Vilhelm Borg's bog om Industriarbejde og arbejderbevidsthed, ${ }^{1}$ nærmere bestemt den bærende teori i bogen: teorien om, at forklaringen på, at

»industriarbejderne i længere perioder har forholdt sig afmægtige og resigneret, opgivet håbet om ændringer af arbejdsforholdene $\ll$,

skal søges i selve den kendsgerning, at det i den moderne storindustri er »maskinsystemet, der behersker arbejderen og dikterer dennes bevægelser og kooperationen «. ${ }^{2}$

Sigurd Jensen lader imidlertid, som om Vilhelm Borg $i k k e$ har fremført denne helt uholdbare teori. Som følge heraf er han for det første nødt til at lade, som

1. Forlaget Røde Hane, København 1971.

2. Ibid.,p. 141 og passim. 
om denne teori ikke er udgangspunktet for diskussionen, og for det andet er han nødt til at give udseende af, at mit indlæg i diskussionen (betitlet: »Den moderne storindustri og arbejderbevægelsens krise. En kritik af Vilhelm Borg's Industriarbejde og arbejderbevidsthed $\aleph^{3}$ ikke eksplicit og fra første til sidste linje er en kritik af den anførte centrale tese i Vilhelm Borg's bog. Som det vil fremgå af det følgende, giver denne forvrængning anledning til en række yderligere forvrængninger.

\section{Rekapitulation: min argumentation}

Min kritik af Vilhelm Borg's teori om, at det er den moderne storindustri, der i kraft af samlebåndsarbejdets særlige natur er årsagen til arbejderbevægelsens krise, bygger på to argumenter:

For det første: Den moderne storindustri fik først sit gennembrud, efter at arbejderbevægelsens krise var indtrådt. Eller rettere: arbejderbevægelsens knusende nederlag efter Første Verdenskrig og den deraf følgende desorganisering, desillusion og resignation var den uomgængeligt nødvendige historiske forudsætning for storindustriens sejrsgang, eftersom samlebåndsarbejdet indebar en radikal forværring af arbejdsbetingelserne. Det er derfor skudt gennem hovedet at ville forklare arbejderbevægelsens krise ud fra den moderne storindustris sejrsgang. ${ }^{4}$

For det andet: Den moderne storindustri indebærer ikke - efter sit gennembrud - en art »cementering « af arbejderbevægelsens historiske nederlag. Samlebåndsarbejdet indebærer, at den enkelte arbejder ikke længere bestemmer sine bevægelser og tempoet individuelt og betyder altså, at den enkelte arbejders faktiske afmagt $\emptyset$ ges; men dette faktum ændrer naturligvis intet ved arbejdernes mulighed for effektiv og offensiv kollektiv aktion for bl.a. »cendringer af arbejdsforholdene «. Det fremgår da også med al ønskelig tydelighed af kampene fra midt i 1930'erne til begyndelsen af 1950'erne i den moderne storindustris højborg: den amerikanske automobilindustri, at arbejderne i den moderne storindustri ikke på nogen måde har været blot en anelse mere passive, opgivende og resignerede end arbejderklassen som helhed. På baggrund af de amerikanske automobilarbejderes offensive og militante kamp gennem tyve år for »kontrol over produktionen " ${ }^{5}$ kan intet tænkende menneske påstå, at samlebåndsarbejdet skulle modvirke endsige knuse »håbet om ændringer $\mathrm{i}$ arbejdsforholdene«. - Forklaringen på, at den krise, arbejderbevægelsen blev hensat i som følge af det verdenshistoriske nederlag i kølvandet på Første Verdenskrig, stadig er en realitet, skal ikke søges i de forværrede arbejdsbe-

3. Proletar! nr. 3, november 1972. pp. 5-11. Fås ved henvendelse til Internationale Sociialister, Dronningensgade 14, 1420 København K; postgirokonto: 194880. (Løssalgspris for enkeltnumre: kr. 6,-).

4. Ibid., pp. 6-8.

5. James Boggs, citeret ibid., p. 9. 
tingelser under samlebåndsarbejdet, men i den lange række af nederlag, som fulgte efter det store verdenshistoriske nederlag: generalstrejken i Storbritannien i 1926, fascismens sejr i Tyskland, den spanske revolutions tragedie, den stalinistiske kontrarevolutions rædselsherredømme i socialismens navn, den »reformistiske « »arbejder « bevægelses stedse mere villige varetagelse af den kapitalistiske stats undertrykkelsesfunktioner, o.s.v., o.s.v. ${ }^{6}$

\section{Sigurd Jensen's generelle kritik}

Efter at have gengivet denne argumentation i nogenlunde genkendelig form i begyndelsen af afsnittet om »Arbejderklassens historiske nederlag « og efter at have afleveret nogle høflige bemærkninger om »positionens styrke« (»klassekampperspektivet«) går Sigurd Jensen over til en indledende generel kritik af »positionen $\ll$. Han skriver:

»Positionens svaghed er [...], at den underkender betydningen af selve den specifikke objektverden [sic!], der møder arbejderen i hans arbejdssituation. Hvorledes præger denne obejktverden arbejderens adfærd og hans bevidsthed om denne adfærd? Har den moderne storindustris ekstreme arbejdsdeling, som bevirker, 'at flertallet af arbejdernes produktive aktivitet er blevet reduceret til tom, abstrakt aktivitet, til et vedhæng til maskinerne, og at dens sammenhæng med de andre arbejderes aktivitet er fastlagt i maskineriet, altså fremmedbestemt - har hele denne specifikke objektverden ingen betydning for arbejderens [!] adfærd [!] og hans [!] bevidsthed [!] om samme [!]? «7

Diskussionen drejer sig bare ikke om »arbejderens adfærd og hans bevidsthed om samme «, men om årsagerne til den udbredte resignation over for arbejdsforholdene! Var den moderne storindustris sejrsgang årsag til arbejderbevægelsens krise? »Cementerer « den moderne storindustri arbejderbevægelsens krise? Problemstillingen er historisk-specifik og dermed politisk operationel og ikke metafysisk-psykologisk. Men selv om jeg gav Sigurd Jensen ret i, at »den specifikke objektverden « har endda meget stor »betydning for arbejderens adfærd og hans bevidsthed om samme«, ville vi ikke være nået en besvarelse af disse spørgsmål så meget som et hanefjed nærmere.

Nogle få sider længere henne i artiklen, i afsnittet »Diskussion«, tager han denne generelle kritik op igen. Denne gang har han imidlertid ændret opfattelse af, hvad diskussionen drejer sig om:

»medens Blauners teknologiske determinisme, der består i antagelsen om en retlinet sammenhæng mellem den tekniske/teknologiske udvikling i produktionsprocessen og arbejderens 'fremmedgørelse', på det bestemteste må afvises, har K. Schmidts konsekvente historiske standpunkt den fordel, at det ser arbejderens dikotome bevidsthed [sic!] som et resultat af arbejderklassens såvel nationale som internationale klassekampserfaringer. Da han imidlertid lige så konsekvent abstraherer fra den betydning, som selve den materielle produktionssammenhængs specifikke objektverden har for arbejderens adfærd og bevidsthed om samme, havner han uværgerligt i det teknologiske determinismes velkendte modpol: voluntarismen.«

6. Ibid., pp. 8-9, 5 .

7. SJ citerer Borg: op.cit., p. 49. 
Diskussionen drejer sig heller ikke om den »dikotome bevidsthed «. Som det også er Sigurd Jensen bekendt, anvender jeg overhovedet ikke begrebet »dikotom bevidsthed « i min artikel. Og det er ingen tilfældighed: Begrebet om den »dikotome bevidsthed « roder to vidt forskellige fænomener sammen i ét begreb; det referer dels til, at samfundet opfattes som værende delt i to lejre (»de $\varnothing$ verste « og »de underste «, »dem « og »os«), og dels til, at der resigneres over for denne »dikotomi«. Det siger sig selv, at det først og fremmest er arbejdernes daglige erfaringer fra den kapitalistiske produktion, der danner grundlaget for, at samfundet opfattes som værende »dikotomt «. Selv om erfaringerne fra klassekampens sejre og nederlag naturligvis bidrager til, at samfundet opfattes som værende »dikotomt «, så vil det ikke kunne forsvares at hævde, at disse »klassekampserfaringer « er det primære - endsige eksklusive grundlag for, at samfundet opfattes som værende »dikotomt«. For så vidt så godt. Men i begrebet om den »dikotome bevidsthed « ligger som sagt almindeligvis også resignationen over for »dikotomien «. Med mindre man kan påvise, at resignationen er en énétydig følge af præcist de samme faktorer, som danner grundlaget for, at samfundet opfattes som værende »dikotomt«, er begrebet derfor videnskabeligt ubrugeligt. Jeg har følgelig omhyggeligt undladt at betjene mig af begrebet om den »dikotome bevidsthed «. Ikke desto mindre påstår Sigurd Jensen frejdigt, at jeg »ser arbejder-ens dikotome bevidsthed som et resultat af arbejderklassens [...] klassekampserfaringer«. Åbent kraniebrud!

Efter denne indledningsvise generelle kritik af min »position « går Sigurd Jensen over til punkt for punkt at tilbagevise mine to argumenter. Lad os følge hans diskussion punkt for punkt.

\section{Diskussion af det første argument}

»Hvad angår det første argument«, skriver han, »vil alene en grundig historisk undersøgelse og rekonstruktion af situationen før, under og efter 1. Verdenskrig kunne afgøre, hvorvidt den resignation og afmagtsfølelse, som bl.a. Popitz kunne konstatere i 50'erne, nu virkelig kun har sit grundlag i det verdenshistoriske nederlag. K. Schmidt leverer ikke selv en sådan analyse, og indtil videre må vi altså vente med at afgøre dette spørgsmål.«

Det spørgsmål, der skulle besvares, var: er den moderne storindustris gennembrud årsag til, at arbejderklassens store flertal resignerer? Dette spørgsmål lader sig besvare uden »en grundig historisk unders $\emptyset$ gelse «, for arbejderbevægelsens verdenshistoriske nederlag og den påfølgende udbredte resignation indtræffer kronologisk $f \phi r$ og er en uomgængelig forudsatning for den moderne storindustris gennembrud. Sigurd Jensen undlader klogeligt at gendrive denne tese.

Men ret skal være ret, og Sigurd Jensen har ret, når han påpeger, at min artikel ikke indeholder en »grundig historisk unders øgelse « af nederlaget efter 
Første Verdenskrig og af hele den følgende udvikling. Der er imidlertid tale om en helt bevidst udeladelse fra min side, idet en sådan undersøgelse for det første er ganske unødvendig for at kunne tilbagevise Vilhelm Borg's teori (og på trods af alle Sigurd Jensen's tilsløringer er det jo formålet med min artikel i Proletar!), og idet en sådan unders $\varnothing$ gelse for det andet ikke er noget man sådan bare fremlægger i et indlæg i en diskussion.

En analogi vil gøre det hele tydeligere: lad os forestille os, at en forvirret person fremfører den teori, at Versailletraktaten er en af hovedårsagerne til Første Verdenskrig; hertil indvender jeg så, at Første Verdenskrig ligger kronologisk før og er en uomgængelig forudsætning for Versailletraktaten, - hvorpå Sigurd Jensen - i overensstemmelse med den logik, han her lægger for dagen fremfører det knusende argument, at alene en grundig historisk undersøgelse af situationen før, under og efter Første Verdenskrig ville kunne afgøre, om Første Verdenskrig danner grundlaget for Potsdam-aftalen!

Spørgsmålet om, hvorvidt den udbredte resignation og afmagtsfølelse i arbejderklassen i 1950'erne (og for den sags skyld også senere) havde »sitgrundlag « i det verdenshistoriske nederlag, hører slet ikke hjemme i denne sammenhæng. For selv om det skulle kunne lade sig gøre at påvise, at resignationen o.s.v. i arbejderklassen i 1950'erne ikke havde sit grundlag i dette nederlag, men havde andre årsager, så rokker det ikke en tøddel ved det første argument, som jo udelukkende siger, at arbejderbevægelsens nederlag o.s.v. går forud for og er en forudsætning for den moderne storindustris gennembrud.

Hele spørgsmålet om årsagerne til den resignation og afmagtsfølelse, som gud og hvermand og Popitz kunne konstatere i 50'erne hører snarere hjemme i forbindelse med det andet argument, idet man - efter at have konstateret, at den moderne storindustri end ikke kan sige at have cementeret resignationen må stille spørgsmålet: hvad er så årsagen til den af alle med øjne i hovedet (»bl.a. Popitz«) konstaterede resignation og afmagtsfølelse. I sit referat af mit standpunkt i afsnittet om »Arbejderklassens historiske nederlag « sammenfatter Sigurd Jensen selv korrekt mit svar på dette spørgsmål således:

»Afmagtsfølelsen og resignationen er snarere blevet cementeret af en række nye historiske nederlag $\ll$.

I min artikel i Proletar! ligger der ikke så meget som en antydning af, at nederlaget i kølvandet på Første Verdenskrig i sig selv, umiddelbart og direkte forårsagede resignation og afmagtsfølelse i store dele af arbejderklassen i 1950'erne, 1960'erne eller 1970'erne - hen over tre, fire eller fem årtier. I forbindelse med en diskussion af Popitz' undersøgelse siger jeg tværtimod udtrykkeligt, at forklaringen på den resignation, som Popitz kunne konstatere hos størstedelen af de 600 adspurgte metalarbejdere i Ruhr i 1953-54 skal søges i de adspurgte arbejderes bitre erfaringer: 
»de revolutionære tyske arbejderes lammende nederlag i begyndelsen af 1920'erne; det Kommunistiske Partis forvandling til et korps af stalinistiske karrieremagere; den socialdemokratiske bevægelses totale fallit over for det tyske samfunds dybe krise; den hensynsløse fascistiske kontrarevolution, der fra den ene dag til den anden knuste alle den tyske arbejderklasses organisationer og sendte henved en halv million af de mest klassebevidste arbejdere i kz-lejr, tugthus o.s.v.; den Anden Verdenskrig og den efterfølgende besættelse; det vanry, som de stalinistiske stater havde bragt socialismen i; den Kolde Krig og den begyndende "uomirakuløse" højkonjunktur ${ }^{8}{ }^{8}$

En »grundig historisk undersøgelse og rekonstruktion af situationen før, under og efter 1. Verdenskrig « er altså ikke ubetinget nødvendig for at kunne besvare spørgsmålet om årsagerne til arbejderklassens resignation i 1950'erne.

Hermed har vi færdigbehandlet de første to sætninger i Sigurd Jensen's kritik af mit første argument. Konfusionen bliver ikke mindre i de følgende sætninger, så hvis læseren føler trang til at fouragere, gå en tur, tisse eller hvile sig, vil det være klogt at gøre det på dette sted, inden vi går videre med den næste sætning:

»Dog kan man allerede nu stille det krav, at analysen [»af situationen før under og efter 1. Verdenskrig «] måtte inddrage den materielle totalsammenhaeng, d.v.s. ikke alene [som partiernes og organisationernes udvikling mod reformismen K. Schmidt]? men også hele den materielle produktions erfaringsbetingelser: det kunne jo være, at det forhold, 'at det store flertal blandt arbejderne i Vesteuropa [...] nærede urokkelige og skæbnesvangre illusioner om en statskapitalistisk udviklings velsignelser' ${ }^{\text {'9 }}$ hvilket $<$ ? $>$ gav udfaldet, hang sammen med deres erfaringer i den materielle produktion!«

»Det kunne jo være«! »Det kunne jo være«, at forklaringen skulle hentes i stjernernes stilling! Når man fremsætter sådanne vage og absolut uspecificerede formodninger om en sammenhæng uden så meget som at forsøge at sandsynliggøre den formodede sammenhæng gennem at pege på, hvordan sammenhængen konkret tænkes at være formidlet, begår man et radikalt brud med grundprincipperne for videnskabelig argumentation. Men lad os - efter at have noteret os dette brud - gå ud fra, at der findes en eller anden sammenhæng mellem arbejdernes »erfaringer i den materielle produktion « og deres »statskapitalistiske« illusioner. (»Det kunne jo være«, at Sigurd Jensen havde ret!). Men selv under forudsætning heraf, falder hans kritik til jorden med et brag: For de arbejdere, hvis urokkelige og skæbnesvangre illusioner om en »statskapitalistisk « udviklings velsignelser han vil forklare ud fra deres »erfaringer i den materielle produktion «, arbejdede ikke under den moderne storindustris vilkår; de var typisk faglærte metalarbejdere og arbejdede ved universalmaskiner (d.v.s. enkelte maskiner, der betjenes af enkelte arbejdere, og som ikke indgår $i$ et integreret produktionsforløb; drejebænken er en typisk universalmaskine). Der er altså tale om præcist de arbejdere, om hvem Vilhelm Borg hævder, at de -

8. Op. cit., p. 5.

9. SJ citerer min artikel, ibid., p. 8. 
til markant forskel fra den moderne storindustris arbejdere - »opfatter sig som producenter « (og så fremdeles i samme dur). ${ }^{10}$ Så hvis deres nederlag skal forklares ud fra deres »erfaringer i den materielle produktion «, så er teorien om, at det er den moderne storindustris gennembrud, der er årsagen til arbejderbevægelsens krise, jo pulveriseret! Dette siger imidlertid i sig selv intet om selve Vilhelm Borg's teori, kun om Sigurd Jensen's vage formodninger og hele argumentationsform. Han skylder os alle en specifikation af, hvilke »erfaringer i den materielle produktion «, der er årsagen til disse arbejderes »statskapitalistiske« illusioner. Er det deres erfaringer som faglærte metalarbejdere ved universalmaskinerne, der er årsagen? Eller er det erfaringer, der er uafhængige af den specifikke produktionsmåde? Er det deres erfaringer som lønarbejdere slet og ret? Er »statskapitalistiske« illusioner altså en byrde, alle lønarbejdere af alle kategorier og til alle tider spontant eller nødvendigvis må bære på? Eller er illusionerne forårsaget af, at der er tale om materiel produktion til forskel fra immateriel produktion (så som »produktion « af kritisk teori)? Eller er det hele bare uforpligtende akademisk spekulation? Eksakt videnskab er det i hvert fald ikke!

Som om han har haft en forudanelse om denne kritik, forsøger han i sin næste sætning at specificere og dokumentere denne formodede sammenhæng. Det er den totale kollaps:

»M. Vester, ${ }^{11}$ der har foretaget grundige undersøgelser af den engelske industris og arbejderklasses udvikling i perioden 1782-1848, har kunnet konstatere en sådan [sic!] sammenhæng: datidens forskellige kontrasterende 'orienteringer' blev repræsenteret og udviklet af bestemte sociale grupper, således at de individuelt producerende havde en tendens til at udvikle restaurative utopier, der skulle virkeliggøres politisk, og som indebar en tilbagevenden til førindustrielle tilstande, medens kooperativt producerende grupper kunne associere sig økonomisk og udvikle industrielle utopier, der skulle virkeligg øres gennem direkte $\varnothing$ konomiske aktioner, og som indebar en bibeholdelse af den industrielle produktionsmåde, men en ændring af produktionsforholdene $\ll$.

Hvad er det $n u$ for en sammenhæng, Sigurd Jensen taler om? Mens Vilhelm Borg og jeg (om jeg så må sige) diskuterede sammenhængen mellem den moderne storindustris gennembrud og arbejderbevægelsens krise, diskuterede $\mathrm{Si}$ gurd Jensen i den umiddelbart forudgående sætning sammenhængen mellem »statskapitalistiske« illusioner og »erfaringer i den materielle produktion« hos de faglærte metalarbejdere i perioden omkring Første Verdenskrig. Men den sammenhæng, han fabler om i denne sætning, ligger et århundrede tidligere og er en helt anden sammenhæng mellem helt andre fænomener. Med »individuelt producerende« mener Vester nemlig udtrykkeligt håndvarkere, mens han med

10. Cf. f. eks. Borg: op. cit., p. 141.

11. S.J. citerer skjult Michael Vester: Die Entstehung des Proletariats als Lernprozess. Die Entstehung Antikapitalistischer Theorie und Praxis in England 1792-1848, Europäische Verlagsanstalt, Frankfurt/M 1970, p. 28. 
»kooperativt producerende « mener lønarbejdere..$^{12}$ Hvad Vester ifølge Sigurd Jensen »har kunnet konstatere « gennem »grundige undersøgelser«, gør Vester selv ikke noget større nummer ud af, idet der jo blot er tale om den gamle marx'ske tese, at håndværkerne som en del af det hendøende småborgerskab og til forskel fra industriproletariatet, der er storindustriens alleregentligste produkt, bekæmper bourgeoisiet for at sikre deres eksistens som middelklasse mod undergang:

»De er altså ikke revolutionære, men konservative. Ja, de er reaktionære, de søger at dreje historiens hjul tilbage«.

»Denne [»småborgerlige«] socialisme klarlagde yderst skarpsindigt modsiggelserne i de moderne produktionsforhold. Den afslørede $\varnothing$ konomernes hykleriske forsk $\varnothing n n e n d e$ fremstilling af forholdene. Den påviste uomstødeligt maskinernes og arbejdsdelingens ødelæggende virkninger, koncentrationen af kapital og jordbesiddelse, overproduktionen, kriserne, småborgernes og-bøndernes nødvendige undergang, proletariatets elendighed, anarkiet i produktionen, de skrigende misforhold i rigdommens fordeling, nationernes indbyrdes industrielle ødelæggelseskrig, opløsningen af de gamle sæder, de gamle familieforhold, de gamle nationaliteter. Men efter sit positive indhold vil denne socialisme enten genindføre de gamle produktions- og samfærdselsmidler og med dem de gamle ejendomsforhold og det gamle samfund, eller den vil med magt spærre de moderne produktions- og samfærdselsmidler inde i de gamle ejendomsforholds rammer, som de selv har sprængt og måtte sprænge. I begge tilfælde er den både reaktionær og utopisk «. O.s.v. ${ }^{13}$

Hvem har benægtet denne sammenhæng mellem håndværkernes og andre småborgeres samfundsmæssige og historiske stilling under kapitalismen og deres notoriske tilbøjelighed til reaktionært-utopisk kritik af kapitalismen? Hvad har denne sammenhæng at gøre med den af Sigurd Jensen formodede (uspecificerede) sammenhæng mellem »statskapitalistiske« illusioner og »erfaringer i den materielle produktion « hos de faglærte metalarbejdere i perioden omkring Første Verdenskrig? Og hvad har den for den sags skyld at gøre med den sammenhæng, som diskussionen hidtil har drejet sig om? Mener Sigurd Jensen, at den gamle marx'ske tese om småborgerskabets reaktionære tilbøjeligheder modbeviser at den moderne storindustris gennembrud ikke kan forklare arbejderklassens resignation?

Forklaringen på det totale kaos i Sigurd Jensen's argumentation skal formentlig søges $i$, at hans forskellige udsagn slet ikke skal forstås som specifikke udsagn om specifikke forhold! Når han siger »statskapitalistiske « illusioner, mener han formentlig ikke »statskapitalistiske illusioner«, ikke engang »illusioner «, men »bevidsthed « overhovedet. Når han siger »restaurative utopier«, mener han tilsvarende formentlig hverken »restaurative utopier « eller blot »utopier«, men »bevidsthed « overhovedet. O.s.v. Og når han siger »moderne storindustri«, »materiel produktion«, »individuel produktion«, »kollektiv pro-

12. Cf. ibid., pp. 27,28, 234-280 og passim. Cf. endvidere bl.a. Max Beer: Allgemeine Geschichte des Sozialismus und der sozialen Kämpfe (1931); Politladen, Erlangen 1971. p. 459.

13. Karl Marx og Friedrich Engels: Det kommunistiske partis manifest (1847/1848); Udvalgte skrifter, København 1952, bd. 1, pp. 26-59; her: pp. 36, 37, 50-51. 
duktion« mener han heller ikke hvad han faktisk siger; han bruger formentlig blot disse udtryk i flæng som lige så mange synonymer for »samfundsmæssig væren«. Sammenhængen i Sigurd Jensens usammenhængende snak skal altså formentlig søges i, at det han forsøger at sige, er, at det er menneskenes samfundsmaessige varen, der bestemmer deres bevidsthed. Og ærligt talt: manden har jo ret!

\section{Diskussion af det andet argument: 1) Flint-strejken o.s.v.}

»Heller ikke eksemplerne fra den amerikanske storindustri forklarer « ifølge Sigurd Jensen »noget som helst om flertallet af arbejdernes afmægtighed og resignation. Den kendsgerning, at der i 1919 [sic!] var 3630 strejker med over 4 millioner deltagere, at der i 1922 [sic!] var 1,6 millioner strejkende o.s.v. o.s.v. - alle disse strejker kan aldrig være hovedproblemet for en revolutionær bevægelse. Selvfølgelig er de vigtige at beskæftige sig med, for så vidt at arbejderbevægelsen kan uddrage erfaringer af sådanne på en gang spontane og organiserede aktioner, erfaringer med de subjektive og objektive betingelser for kollektiv aktion. Men her kan let ske en proportionsforvrængning! At 1, 2 eller 3 millioner udbyttede arbejdere går i strejke, er hverken i strid med Borgs analyse eller burde undre nogen som helst: ikke den kendsgerning, at den udbyttede strejker eller den sultne stjæler [sic!], behøver en særskilt forklaring, men derimod den historiske kendsgerning, at det kun [sic!] var 1, 2 eller 3 millioner og ikke flertallet af de udbyttede arbejdere, der gik i strejke! Dette? problem, som er den væsentligste årsag til, at mange begrænsede og isolerede strejker nødvendigvis [sic!] må ende med nederlag, behandles ikke, - ja, stilles egentlig ikke engang af K. Schmidt. Når han skal forklare 'Flint-strejkens' (1936-) og hele den efterfølgende bevægelses nederlag, anfører han kun [sic!] desangående, at det altovervejende flertal af amerikanske arbejdere (de millitante ibergnet) nærede 'fatale illusioner om Roosevelt-administrationens statskapitalistiske tendens og hensigter'. Men det virkeligt centrale problem er jo, hvorfor de anså reformistiske løsninger på deres problemer som en mulighed, hvorfor de foretrak dem frem for revolutionære løsninger«.

Det er efterhånden blevet bøjet i neon, at Sigurd Jensen stikker til halsen i psykologiens ahistoriske og fundamentalt metafysiske tænkemåde: han raver rundt i denne verden, virkelighedens, den strenge kronologis og de hårde kendsgerningers verden som en beruset spastiker i en mørklagt porcelænsbutik!

»Eksemplerne fra den amerikanske storindustri« skulle ikke »forklare noget som helst om flertallet af arbejdernes afmægtighed og resignation «, men skulle derimod vise, at den enkelte arbejders underordning under maskinen ikke førte til nogen som helst form for »cementering « af den af nederlaget fremkaldte resignation m.v.

Men bortset fra det, så er det ikke underligt, at Sigurd Jensen ikke kan se betydningen af »eksemplerne«, for det er de forkerte »eksempler«, han diskuterer! Han diskuterer ikke hele den bevægelse fra midt i 1930'erne til begyndelsen af 1950'erne, som Flint-strejken var det indledende højdepunkt i, og som jeg anfører som belæg for min tese om, at samlebåndsarbejdet ikke har modvirket eller knust »håbet om ændringer i arbejdsforholdene «. Han diskuterer udelukkende strejkebevagelsen i kølvandet på Første Verdenskrig. Jeg var så letsindig indledningsvis og som baggrund for gennemgangen af Flint-strejken 
o.s.v. at anføre de vigtigste data om denne bevægelse for at vise, at »også det amerikanske proletariat havde deltaget i det store opgør i kølvandet på Første Verdenskrig«, og for at vise, at »også den amerikanske arbejderklasse fik det internationale proletariats almindelige nederlag at føle $\ll .{ }^{14}$ Det er udelukkende disse baggrundsoplysninger, som nærmest har karakter af regibemærkninger, Sigurd Jensen diskuterer! Enhver idiot burde kunne regne ud, at kendsgerningerne om en strejkebevægelse $f \phi r$ den moderne storindustris gennembrud er lige så lidt »i strid med Borgs analyse« som hunnernes overgang over Volga!

Det er derimod en knusende gendrivelse af »Borgs analyse «, at millioner af amerikanske arbejdere i den moderne storindustris højborg, den amerikanske automobilindustri, absolut ikke resignerede over for ændringer af arbejdsforholdene, men tværtimod gennem tyve år kæmpede indædt og vedholdende for »kontrol over produktionen«. Selv om jeg bruger en meget stor del af min artikel på at beskrive denne bevægelse og eksplicit konkluderer, at man på baggrund af denne beskrivelse ikke kan »fastholde idéen om, at den moderne storindustris sejrsgang skulle have 'cementeret' det verdenshistoriske nederlag «, undlader Sigurd Jensen omhyggeligt at tage stilling til, om hele denne beskrivelse gendriver, hvad den således eksplicit tilsigter at gendrive. Han omtaler udelukkende Flintstrejken o.s.v. for at antyde, at denne bevægelses nederlag skal forklares ud fra samlebåndsarbejdets natur:

»Når han skal forklare 'Flintstejkens' [...] og hele den efterfølgende bevægelses nederlag, anfører han kun [sic!] desangående, at det altovervejende flertal af amerikanske arbejdere (de militante iberegnet) nærede 'fatale illusioner om Rooseveltadministrationens statskapitalistiske tenddens og hensigter'. Men det virkelig centrale problem er jo, hvorfor masserne anså reformistiske løsninger på deres problemer som en mulighed, hvorfor de foretrak dem frem for revolutionære løsninger«.

Ikke nok med at Sigurd Jensen undlader at tage stilling til min argumentation! Ikke nok med at han kun berører Flint-strejken o.s.v. i forbindelse med en diskussion af min forklaring på denne bevægelses nederlag! Han kan end ikke give et hæderligt referat af denne forklaring! I min artikel i Proletar! nr. 3 skriver jeg nemlig udtrykkeligt:

»Skal man forklare denne militante arbejderbevægelses nederlag, må man også i dette tilfælde søge forklaringen i de specifikke historiske omstændigheder. Forklaringen må søges i de fatale illusioner om Roosevelt-administrationens statskapitalistiske tendens og hensigter, som det altovervejende flertal af amerikanske arbejdere (de militante arbejdere medregnet) lå under for. Den må søges i den tidlige integration af CIO's ledelse i Roosevelt-administrationens statskapitalistiske forehavende og den deraf følgende forvandling af CIO til det statslige undertrykkelsesapparats forlængede arm. Den må endvidere søges i, at det ikke lykkedes den militante arbejderbevægelse at opbygge et politisk lederskab organiseret i et revolutionært parti. Forklaringen må altså søges i den amerikanske arbejderklasses manglende evne til at forvare sig effektivt mod den herskende klasses modoffensiv, da denne satte ind under og især efter krigen. Forklaringen må derudover søges i, at den amerikanske arbejderbevægelses offensiv var og blev isoleret, en undtagelse i en fundamentalt kontrarevolutionær epoke (den er som bekendt samtidig med den stalinistiske kontrarevolution i

14. Op. cit., p. 9. 
Sovjetunionen, den fascistiske kontrarevolution i Tyskland, Italien, Spanien o.s.v.). Og den må endelig søges i den kendsgerning, at den herskende klasse i USA efter Anden Verdenskrig fremstod som noget nær verdens herre. Stillet over for denne enorme magt; isoleret i en verden, hvor enhver selvstændig proletarisk bevægelse var knust; katastrofalt forvirret som følge af statskapitalistiske illusioner og uden et virkeligt rodfæstet politisk lederskab, - således stillet måtte den militante bevægelse i den amerikanske storindustri lide nederlag $\ll .{ }^{15}$

Man skal virkelig have en mangeårig universitetsuddannelse bag sig for at kunne få denne forklaring på nederlaget reduceret til »kun« at anføre arbejdernes »statskapitalistiske illusioner«. En formidabel intellektuel kraftpræstation!

Det er meget godt, vil mange måske sige, men hvad er svaret på det spørgsmål, som Sigurd Jensen rejser:

»hvorfor [anså masserne] reformistiske løsninger på deres problemer som en mulighed, hvorfor [foretrak de] dem frem for revolutionære løsninger«?

Dette spørgsmål kan kun blive et alvorligt problem for folk, som kan finde intellektuel tilfredsstillelse $\mathrm{i}$ at fremføre sådanne tomme og barnagtige fraser som, at det ikke burde undre nogen som helst, at 1, 2 eller 3 millioner udbyttede arbejdere går i strejke. Sagen er, at hvis »reformistiske« løsninger forekommer mulige og realistiske, så foretrækkes de naturligvis frem for revolutionens hav af blod og slam. Med Lenin's ord, som Sigurd Jensen endda selv citerer: Masserne anser »reformistiske løsninger som en mulighed, så længe de ikke ved egen erfaring har indset, at den reformistiske vej er forbundet med endnu større risici end den revolutionære. For at hele klassen, for at de arbejdende og af kapitalen undertrykte brede masser kan nå frem til et revolutionært standpunkt, er massernes egne politiske erfaringer nфdvendig. Dette, fortsætter Lenin, er alle store revolutioners grundlov.

»For resolut at gå over til kommunismen måtte ikke blot Ruslands masser, som står på et lavt kulturniveau og ofte hverken kan læse eller skrive, men også Tysklands masser, som står, på et højt kulturniveau og alle kan læse og skrive, korporligt erfare hele magtesløsheden, hele karakterløsheden, hele hjælpeløsheden, hele kryberiet over for bourgeoisiet, hele gemenheden hos regeringen af II. Internationales riddere $[\ldots]$ som eneste alternativ til proletariatets diktatur «. ${ }^{16}$

»Revolutionens grundlov, som er blevet bekræftet af alle revolutioner og især alle tre russiske revolutioner i det 20. århundrede, består i følgende: for revolutionen er det ikke tilstrækkeligt, at de udbyttede og undertrykte masser indser umuligheden af at leve videre på den gamle vis og kræver en forandring: for revolutionen er det nødvendigt, at udbytterne ikke kan leve og styre på den gamle vis. Først når de 'lavere lag' ikke vil og de 'øvre lag' ikke kan fortsætte på den gamle vis, først da kan revolutionen sejre. Denne sandhed kan også udtrykkes med andre ord: revolutionen er ikke mulig uden en almen national krise «. ${ }^{17}$

15. Ibid.

16. V. I. Lenin: »Venstre«-kommunismen, en børnesygdom (1920); Forlaget Tiden. København 1970, p. 82. (Kursiveringen er min, KS).

17. Ibid., pp. 73-74. 
De amerikanske arbejdere havde ikke korporligt erfaret, hvad de russiske og (til en vis grad) de tyske masser havde erfaret på deres krop; den økonomiskpolitiske krise var ikke nået dertil, at »de mest reaktionæres diktatur « var det eneste alternativ til proletariatets diktatur; den herskende klasse havde ikke udtømt sine muligheder for at fortsætte på den gamle vis; den revolutionære vej ville derimod (for den almindelige arbejder at se) med usvigelig sikkerhed føre til det samme afskyelige resultat som i Rusland; der forelå ikke nogen almen national krise, o.s.v.; på det tidspunkt, hvor arbejdernes egne praktisk-politiske erfaringer havde svækket deres illusioner om CIO o.s.v. afgørende, var den herskende klasse derimod blevet afgørende styrket, nationalt såvel som internationalt, o.s.v. Forklaringen på, at de amerikanske arbejdere ikke nåede frem til et revolutionært standpunkt, og at de derfor måtte lide nederlag, skal altså søges i de specifikke historiske omstændigheder, som jeg antydningsvis skitserede som afslutning på min gennemgang af Flint-strejken o.s.v.

\section{Diskussion af det andet argument:}

\section{2) »erfaringerne i den materielle produktion«}

»K. Schmidts andet argument [...] går ud på, at selve den store industris kooperation, som for 'flertallet' af arbejderne har betydet, at deres 'produktive aktivitet er blevet reduceret til tom, abstrakt aktivitet, til et vedhæng til maskinerne, og at dens sammenhæng med de andre arbejderes aktivitet er fastlagt i maskineriet, altså fremmedbestemt' ${ }^{\prime 18}$ - at selve denne materielle kendsgerning intet som helst har at gøre med arbejdernes afmagtsfølelse og deres resignation over for de livsbetingelser, som klassesamfundet sætter for arbejderklassens medlemmer«.

Det er her lykkedes Sigurd Jensen at fastholde så nogenlunde, hvad min argumentation går ud på: samlebåndsarbejdets særlige natur har ikke cementeret arbejdernes afmagtsfølelse og deres resignation over for de livsbetingelser, som klassesamfundet sætter... Men det er naturligvis for meget forlangt, at han i næste sætning skal kunne huske, hvad han netop har refereret mig for:

»Ud fra et virkeligt materialistisk standpunkt er denne antagelse absurd og må i egentlig forstand virke som en kniv i ryggen på de arbejdere, der dagligt og i årevis har erfaret vold, undertrykkelse og fremmedgørelse i den materielle produktion, og for hvem indskrænkelsen af livsmuligheder og bevægelsesfrihed har en umiddelbar, materiel og sanseligt anskuelig evidens! Kun en venstreintellektuel, hvis livssammenhæng overvejende ligger uden for den materielle produktion i industrien, kan med et par pennestrøg fraskrive arbejdernes selverfaringer enhver betydning for deres politiske bevidsthed og praktisk-politiske engagement «.

Hvem har benægtet, at arbejderne »dagligt og i årevis har erfaret vold, undertrykkelse og fremmedgørelse i den materielle produktion«? Hvem har benægtet, at »indskrænkelsen af livsmuligheder og bevægelsesfrihed har en umiddelbar, materiel og sanseligt anskueligt evidens « for arbejderne?

18. SJ citerer Borg: op. cit., p. 49. 
Hvem fraskriver (det være sig med ét eller flere pennestrøg) »arbejdernes selverfaringer enhver betydning for deres politiske engagement«? Ikke jeg!. Hvad jeg derimod har benægtet pure, er, at arbejderne resignerer overfor de livsbetingelser, som klassesamfundet sætter for arbejderklassens medlemmer «, fordi de »dagligt og i årevis har erfaret vold, undertrykkelse og fremmedgørelse i den materielle produktion «, eller med andre ord fordi de tilhører en undertrykt og udbyttet klasse.

At det er denne groteske fordom, der ligger til grund for Sigurd Jensen's kritik af min artikel, fremgår ikke blot indirekte af hans netop anførte indvendinger, men også direkte og med al ønskelig tydelighed af de næste sætninger. Umiddelbart i forlængelse af det netop citerede afsnit anfører Sigurd Jensen nogle FIAT-arbejderes udtalelser om deres arbejdsforhold; derefter fortsætter han:

»I disse vurderinger af deres eget arbejde, hvad det gør ved dem, udtrykker Fiat-arbejderne deres konkrete erfaringer med ufrihed, d.v.s. med indskrænkelsen af deres faktiske, fysiske bevægelsesspillerum, deres erfaringer med maskinen som noget, der dagligt udøver tryk og tvang på arbejderens liv, som noget, der fremstår som en fremmed magt, der behersker såvel ham som de andre arbejdere og anvender dem til at producere. At langt det overvejende flertal af arbejderne nødvendigvis må gøre sådanne erfaringer bliver forståeligt, når man betænker de erfaringsbetingelser, som den strukturelle kooperation konstituerer for arbejderne. De fleste arbejdere tilbringer nemlig størstedelen af deres vågne liv på en arbejdsplads, der er fast afgrænset, og som indskrænker deres bevægelsesfrihed: den enkelte arbejdsplads' arbejdsoperation, dens såvel rumlige som tidsmæssige dimension, er vidtgående bestemt af maskinsystemet. Fabrikkens rumlige område som helhed unddrager sig dermed arbejdernes umiddelbare, anskuelige erfaringsverden (oplevelses-). Kun visse grupper såsom mestre, formænd, tillidsmænd, sikkerhedsrepræsentanter, de såkaldte 'springere' eller 'afløsere' ved et samlebånd, kan - og må ofte nødvendigvis - skaffe sig et overblik over fabrikkens område som helhed. Men flertallet af arbejderne er hele dagen bundet til en del af fabrikkens totalmaskineri, der fremtræder kun fragmentarisk for dem. Alene dette faktum reprasenterer en enorm blokering: da maskineriet ikke kan opleves og erfares som helhed, fremtrader det for flertallet af arbejderne som en fremmed magt, antager form af en mystificeret objektverden. (En unders $\varnothing-$ gelse af de i dag aktive politiske arbejdere herhjemme ville givetvis vise, at de havde specialjobs, d.v.s. passe f.eks. en bestemt maskine, eller var såkaldte 'springere' ved et samlebånd). ${ }^{19}$

Vejen fra den ovennævnte indskrænkede erfaringsbasis til arbejdernes oplevelse af kapitalmystifikationen er ikke lang, altså til det forhold, at kapitalen i arbejdernes oplevelse fremstår som en fremmed magt, der behersker og kontrollerer dem, og som ikke er et produkt af deres eget arbejde, og at arbejdets samfundsmæssige produktivkraft, kooperationens produktivitet, fremstår som kapitalens iboende kraft (produktiv-) og ikke som en kraft, der udspringer af deres egen kollektive kraft«.

Erindrer man sig, at Sigurd Jensen med hele denne pretentiøse smøre vil gendrive, at samlebåndsarbejdets natur »intet som helst har at gøre med arbejdernes afmagtsfølelse« o.s.v., bliver det sanseligt anskueligt, at Sigurd Jensen de høflige bemærkninger om den historiske synsvinkel og de nedsættende bemærkninger om den teknologiske determinisme til trods - er mindst lige så ekstremt objektivistisk som Vilhelm Borg. Det er - også ifølge Sigurd Jensen -

19. Nogle af kursiveringerne er mine, KS. 
den moderne storindustri, der i kraft af samlebåndsarbejdets særlige natur er årsagen (eller hovedårsagen) til, at arbejderklassens store flertal resigneret affinder sig med den bestående kapitalistiske samfundsorden.

Ligesom Vilhelm Borg og til forskel fra Robert Blauner ved Sigurd Jensen naturligvis, at det ikke er det »store maskineri« som sådant, der binder arbejderen til sin arbejdsplads o.s.v.; arbejderen bindes »af « maskineriet, fordi der er tale om kapitalistisk anvendt maskineri. Nu gemmer han ganske vist denne erkendelse godt og grundigt, ja, han giver faktisk udtryk for den stik modsatte erkendelse i sit ordvalg, f.eks. når han siger:

»Vejen [!] fra [!] den ovennævnte indskrænkede erfaringsbasis til [!] arbejderens oplevelse af kapitalmystifikationen [!] er ikke lang [sic!]«.

For hvis det ikke er selve den kapitalistiske undertrykkelse, arbejderne f. eks. erfarer i og med »indskrænkelsen af deres faktiske, fysiske bevægelsesspillerum«, - hvad fanden er det så? Maskinmystifikationen? Men lad os gå ud fra, at der blot er tale om en lapsus af de mere grove, og at Sigurd Jensen vedstår kritikken af den »teknologiske determinisme«. Dette ændrer imidlertid ikke en tøddel ved den kendsgerning, at hans standpunkt er ekstremt objektivistisk:

Årsagerne til, at arbejderklassens overvældende flertal resigneret affinder sig med den bestående kapitalistiske samfundsorden, søges (udelukkende eller primært) i »deres erfaringer i den materielle produktion «; samlebåndsarbejderne resignerer - ifølge Sigurd Jensen - fordi de ikke kan se den anden ende af båndet o.s.v.; fordi de ikke kan overskue produktionsprocessens struktur; fordi deres arbejde er forudbestemt; fordi de må indrette sig efter maskineriets bevægelser og rytme; fordi de dagligt og i årevis har erfaret vold, undertrykkelse og fremmedgørelse i den materielle produktion, o.s.v. - kort sagt: fordi de er underkastet typisk kapitalistiske arbejdsforhold.

Sigurd Jensen forudsætter altså som givet, at vold, undertrykkelse og fremmedgørelse avler resignation og afmagtsfølelse. Men dermed forudsætter han jo netop, hvad han skulle vise!

\section{Politiske konsekvenser}

For nogle år siden var det bogstaveligt talt god latin at sige, at arbejderne var »fremmedgjorte « og derfor var ude af stand til at handle revolutionært. I og med Sigurd Jensen's artikel i dette nummer af Kurasje bliver det tydeligt, at hele den objektivitiske teori om, at forklaringen på resignationen skal søges i samlebåndsarbejdets natur, blot er en lidt bedaget akademisk variant af præcist den samme ideologiske forestilling.

Når Sigurd Jensen stiltiende forudsætter, at den undertrykte klasse resignerer over for undertrykkelsen, fordi den er undertrykt, så betyder det, at arbejderklassens frigørelse ikke kan være arbjderklassens eget værk; der er således ikke blot tale om en lapsus, en formel fejl, dårlig tænkning, eller hvad man nu 
vil; der er tale om en fordomsbestemt lapsus, en fordomsbestemt formel fejl, fordomsbestemt dårlig tænkning, eller hvad man nu vil. Fra første til sidste linje oser hans artikel langt væk af det selvglade intellektuelle småborgerskabs paternalistiske og elitære fordomme om arbejderklassen:

»Intelligensens [!] arbejdsmåde er i dag det eneste [!] middel, vi kender, som kan ophæve den illusionære [!] sammenhæng mellem arbejderens objektive situation og hans bevidsthed om samme: netop intelligensens abstraktionsformåen er et instrument, der muliggør indsigt i de fremmedgjore sociale forhold $\ll$.

Den »kritiske teori« (ånden fra Frankfurt!) er imidlertid blevet »henvist til universiteterne o.l.«. Alle de vanskeligheder, »der i dag eksisterer i fors øget på at formidle teori og praksis«, hænger »i sidste ende «.

»sammen med, at intelligensens politisering indtil videre ikke er særlig fremskreden, at den endnu ikke har formået at identificere sine egne [sic!] samfundsmassige interesser [sic!] og opbygge egne [sic!] organisationer «.

»Intelligensens arbejdsmåde« vil kun kunne være »en hjælp for arbejderen«, »hvis den transformeredes kollektivt og etablerede sig påny i arbejderens erfaringssammenhæng«.

Denne »kollektive transformation « (verdens ottende vidunder!) skal tilvejebringes gennem »fabriksnær arbejderoplysning«, der skal

»lære deltagerne en tænkemåde, der gør det muligt for dem at forstå sammenhængen mellem deres individuelle skæbner og den samfundsmæssige udvikling«.

Problemet er blot, at den »fabriksnære arbejderoplysning « forudsætter en »offensiv fagforeningsstrategi«, men at fagforeningerne jo har accepteret »klassesamarbejdet $\ll$.

»Denne modsigelse kan kun [!] løses [!] ved st støtte sig til 'progressive' tendenser inden for fagforeningen [!], da den dag i dag de fleste arbejdere har bundet deres loyalitet [!] til fagforeningerne .

Strategien er klar nok: »intelligensen « skal organisere sig selvstændigt til forsvar for sine egne samfundsmæssige interesser og skal således organiseret samarbejde med »progressive« fagpampere om en »fabriksnær arbejderoplysning «, o.s.v. ${ }^{20}$

20. Som påpeget af Dorrit Schmidt (»Sprog og klasse«; Vindrosen, nr. 2, 1973, pp. 13-42) har den strategi, Sigurd Jensen argumenterer for, lidt et ynkeligt skibbrud: »Netop Oskar Negts fors $\emptyset \mathrm{g}$ på at lave en form for marxistisk skoling med udnyttelse af en bevidst udformet pædagogisk metode inden for fagbureaukratiet i Vesttyskland viser, hvor forgæves selv den bedste pædagogik er til formidling af politisk teori, når denne løsrives fra en praktiskpolitisk sammenhæng. [...] Af de ca. 2000 arbejdere, der gennemgik den intensive skoling, vendte kun en rine andel tilbage til virksomhederne og formidlede skolingen videre til deres arbejdskammerater på 'fabriksgulvet'. Størstedelen af de 2000 brugte uddannelsen som et springbræt bort fra arbejdertilværelsen - dels som et middel til individuel opstigning inden for fagforeningshierarkiet, dels som etmiddel til at gå ind i de institutionaliserede 
Det er alt sammen i nydeligste overensstemmelse med den klassebestemte fordom om, at arbejderne resignerer, fordi de tilhører en undertrykt klasse. Men virkeligheden er det ikke overensstemmelse med! I virkeligheden resignerer det store flertal af arbejdere, fordi deres klasse gennem en menneskealder har lidt det ene forsmædelige, demoraliserende og desorganiserende nederlag efter det andet, og fordi de som følge af denne lange række af nederlag i dag står i en situation, hvor »deres « organisationer villigt vretager den herskende klasses undertrykkelsesopgaver, og hvor »socialismen « midlt sagt er bragt i vanry. I denne situation er det på den ene side kommunisternes ufravigelige pligt at deltage i arbejdernes kampe, dels for derigennem at bidrage til de - store som små - sejre, arbejderklassen så bittert behøver, dels for derigennem at bidrage til opbygningen af det revolutionære arbejderparti, der er den eneste kraft, der kan varetage den opgave, som Sigurd Jensen klassebevidst tildeler »intelligensen«: det revolutionære lederskab. På den anden side er det i denne situation deres lige så ufravigelige pligt ikke at sky noget middel for at forklare de »militante « arbejdere, der i dag forsvarer deres klasses interesser, uanset at de derved kommer i opposition til det faglige bureaukrati (de »progressive« tendenser medregnet), hvorledes det kunne gå til, at verdenshisoriens første arbejderstat tilsyneladende »førte til« en ny og endnu mere barbarisk form for undertrykkelse af den arbejdende befolkning... ${ }^{21}$

repræsentative organer i virksomhederne (samarbejdsudvalg o.1.). Netop disse erfaringer fra Tyskland understreger nødvendigheden af, at den politiske skoling må foregå i en praktiskpolitisk sammenhæng og ikke i en rent faglig sammenhæng eller ren skolingssammenhæng. Den må foregå som led i arbejdet i revolutionære politiske organisationer, i fagoppositionelle sammenhænge o.l. Den politiske skoling kan ikke adskilles (organisatorisk, praktisk, politisk) fra politisk agitationsarbejde, fra opbygningen af nye slagkraftige organisationer «. (pp. 41-42). Sigurd Jensen har kendt disse erfaringer i to år, men de kan åbenbart hverken anfægte ham eller få ham til at antyde, at der måske kunne tænkes at være problemer.

21. Disse afsluttende bemærkninger er naturligvis langt fra en udtømmende beskrivelse af de foreliggende opgaver. Med disse bemærkninger forsøger jeg blot at pege på denne diskussions politiske konsekvenser. Hvad en mere udtømmende diskussion af de foreliggende opgaver angår, jvf. f.eks. Kommunistisk Forbund's og Internationale Socialister's bidrag til politisk revy's enquete om det partiopbyggende arbejde. 


\section{Bedriftskooperation*}

\section{Konrad Frielingshaus}

To gange i løbet af Tysklands nyeste historie, da stats- og industriapparatet var sat ud af funktion på grund af krigskatastrofer, var det industriarbejderne, ledet af bedriftsrådene, som begyndte den organisatoriske og praktiske opbygning af industrien. I disse perioder betragtede arbejderne oprettelsen af bedriftsråd som en basis for en ny samfundsorden, som et alternativ til de sammenbrudte magtapparater, hvis repræsentanter var belastet med ansvaret for katastroferne. Men hverken efter 1918 eller efter 1945 kunne bedriftsrådene opretholde denne samfundsmæssige stilling i længere tid. På få år genvandt de gamle magtapparater deres position. Repræsentanterne for den gamle periode skød ansvaret for katastrofen fra sig og etablerede sig som dem, der nød den største fordel af det genopbygningsarbejde, som arbejderne havde ydet. Nu baner de atter vejen for en udvikling, som truer med at føre over industriel blomstring og magtudfoldelse til katastrofe.

* Oversat i uddrag fra »Belegschafts-Kooperation«, Heidelberger Blätter 14/16, 1969-70, side 112-159. 


\section{Den truende krise!}

I takt med bank- og koncerngrupperne genoprettede deres herredømme over samfundet, sank industriarbejderne igen ned til at blive objekt for dette herredømme, ikke mindst fordi arbejderne glemte det håb og den forventning, som de havde knyttet til bedriftrådsperioden - som et historisk vendepunkt. Ligesom denne udvikling i Weimarrepublikken fandt sin afslutning med »bedriftsrådsloven «, således måtte også bedriftsrådene efter 1945 finde sig i en spændetrøje »virksomhedsforfatningsloven «, som så at sige var en kapitulationserklæring.

Men hvordan var det muligt at arbejderne og deres bedriftsråd efter en kort periode lod sig trænge bort fra den position, der tilkom dem? En af grundene er, at de nok var sig deres funktion som producenter i det samfundsmæssige liv bevidst, men var uden bevidsthed om deres samfundspolitiske funktion. De var ikke forberedt på at forsvare og udbygge deres politiske position, som de kun betragtede som et undtagelsestilfælde. De var ikke forberedt på at fratage de for katastrofen ansvarlige enhver form for indflydelse på samfundet i fremtiden, at hindre disse i atter at opbygge deres magtapparater.

Her gælder det om at uddrage en lære for fremtiden!

Påvirket af »Wirtschaftswunder« og den stigende levestandard hengiver flertallet sig nu til skønne forhåbninger om, at udviklingen skal forløbe forholdsvis krisefri og fredelig, som tilfældet har været i de sidste ti år. Man overser, at i løbet af disse ti år er alle de faktorer og kræfter atter blevet virksomme, som allerede to gange har ført til katastrofe.

De herskende kredse tror øjensynligt selv mindre på en sådan fredelig, krisefri udvikling. De indkalkulerer til stadighed nye katastrofer i deres planer og er ligefrem feberagtigt beskæftiget med at forberede sig på alle eventualiteter. Disse forberedelser har nået deres foreløbige højdepunkt med forelæggelsen af »Notstandsgesetze « (kriseloven). Deres »kriselov« sørger ikke for, at man i rette tide skal kunne drage de for krisen ansvarlige til ansvar. Tværtimod er den indrettet på at give de for krisen ansvarlige amnesti, at legetimisere dem på forhånd, og at opretholde deres magt og indflydelse for enhver pris. Derved tillades det dem at drive krisen ud i katastrofen i overensstemmelse med en praksis, som de herskende bankog koncerngrupper samt deres påhæng allerede to gange i de sidste 50 år har gennemprøvet. Disse folk lader sig ganske vist forherlige som de ansvarlige for den industrielle produktivitets successer og fremskridt. Men ansvaret for kriserne og katastroferne, som faktisk hviler hos dem, skyder de over på andre; enten på »skæbnen «, socialisterne, jøderne eller i mangel af bedre på de af dem igangsatte kreaturer som Wilhelm II og Hitler alt efter hvad der netop forekommer dem opportunt.

Hvad må der først og fremmest gøres? Først er det nødvendigt at erkende de kræfter og tendenser, som idag bestemmer den samfundsmæssige udvikling; en erkendelse der alene kan bestemme den politik der må føres, i overensstemmelse med den gamle arbejderbevægelses bevingede ord: »Viden er magt!«. Her er 
det især én kraft og én tendens der behandles og lægges frem til diskussion: den industrielle kooperations moderne form og dens socialrevolutionære karakter.

\section{Kooperation i den moderne industri}

Ifølge den fremherskende mening sker der intet $\mathrm{i}$ de industrielle foretagender uden viden, plan, afgørelse, befaling og anvisning fra virksomhedshierakiet med direktøren i spidsen. Arbejderne og funktionærerne forestiller man sig derimod som rene og skære udførelsesorganer, hvis hele nytte består i deres lydighed.

Forholdet mellem hierakiets medlemmer reguleres ved hjælp af strenge over- og underordningsforhold. Den store personalemasse - således forestiller man sig det - står derimod ikke i nogen indbyrdes relation, i hvert fald ikke i nogen for produktionen væsentlig relation. Eftersom ethvert personalemedlem bliver ansat enkeltvist og individuelt, får udbetalt løn, får anvist arbejdsart og arbejdssted og er underlagt hierakiets direktions- og diciplinærmyndighed, fremtræder den enkelte og individuelle ansatte som separat organ i hierakiet.

I denne opfattelse har »Herren - i - huset « - standpunktet sit grundlag. Efter sigende behøver den komplicerede industriproduktion en særlig »stram organisation «, inddelt i to grupper folk, hvor den ene gruppes opgave er at give ordre, den andens er at adlyde. Denne opfattelse modsiges imidlertid af en erfaring, som enhver industriarbejder, der betjener en kompliceret maskine i en moderne virksomhed, kunne gøre hver eneste dag hvis han, når han stødte på en vanskelighed i sit arbejde, gik til værkføreren for at få hjælp, som det passer sig for et udførende, lydigt organ. Han ville få at vide, at man ikke kunne bruge en mand, der ikke kan hjælpe sig selv ved et kompliceret maskineri.

I den moderne højproduktive industri kan værkførerne ikke gøre nogen specielle erfaringer med hver enkelt maskine i deres afdeling og derfor heller ikke give nogen praktiske anvisninger på, hvorledes vanskelighederne kan overvindes. Hvis de skal det, må de henvende sig til specialisterne i den tekniske afdeling, eller rekvirere folk fra reparationsafdelingen, eller vende sig til en særlig erfaren arbejder i deres afdeling. En erfaren industriarbejder kan forklare specialisterne vanskelighederne ved sit arbejde meget bedre end værkføreren. Han ved af erfaring hvilken kollega, der i det givne tilfælde bedst kan råde og vejlede. Derfor vender han sig til trods for den »stramme organisation« og den hierakiske ordning ikke til værkføreren, men »hjælper sig selv « ved at rådslå med disse kolleger.

Ofte opstår vanskelighederne på en arbejdsplads ikke på grund af selve maskineriet, men på grund af det leverede materiale, altså på grund af uregelmæssigheder i et forudgående delarbejde i den arbejdsdelte produktionsproces. Ifølge den hierakiske ordnings principper burde arbejderen komme til værkføreren med sine vanskeligheder. Denne burde melde klagen over det leverede materiale til virksomhedsledelsen. Virksomhedsledelsen burde beordre værkføreren fra den afdeling, hvorfra det påtalte materiale var kommet, til at levere forskiftsmæssigt materiale. Endelig burde denne værkfører videregive ordren til 
den arbejder, som producerer vedkommende materiale. Men da han i de fleste tilfælde ikke er i stand til at sige til vedkommende arbejder, hvad det er, denne i enkeltheder skal gøre anderledes, må han rekvirere specialister. Erfarne industriarbejdere »hjælper sig selv«. De er ligeglade med det hierakiske apparat. De går til den kollega, der i den anden afdeling producerer materialet og overvejer sammen med ham, hvad der kan gøres. Om nødvendigt tager de en specialist med på råd. Værkfører og virksomhedsledelse lærer ikke sagen at kende, eller gør det først når vanskeligheder er overvundet og produktionen atter i gang.

En tildragelse fra en apparaturfabrik giver os et talende eksempel på denne praksis. På denne virksomheds svejseafdeling blev der hver to til fire måneder, alt efter ordretilgangen, sat en serie på 200 kasser til knusningsapparater i produktion. Kasserne blev svejset af 4 pressede og stansede plader, som man fik leveret fra et presse- og stanseværk i en anden by i serier på 200 stk. Svejsearbejdet blev altid udført på akkord af de samme to svejsere.

Da svejserne ved påbegyndelsen af en ny serie opdagede, at der i en af de fire plader manglede et for monteringen nødvendigt stansehul, telefonerede de til den ansvarlige indkøber i indkøbsafdelingen, for at denne kunne sætte sig i forbindelse med presse- og stanseværket. Indkøberen erfarede gennem dette værks salgschef, at ordren denne gang havde måttet gives videre til en anden virksomhed som underlevering, fordi en af pressemaskinerne var gået i stykker, og at fejlen muligvis var opstået af den grund. Han ville straks undersøge sagen og give besked om, hvordan den igen kunne bringes i orden.

I mellemtiden gik de to svejsere over i monteringsafdelingen for at undersøge nøjagtigt, hvorfor hullet var nødvendigt, og for at fastslå, om de i givet fald selv kunne brænde hullet ud.

Gennem rådslagning med monteringsfolkene opdagede de, at hullet overhovedet ikke længere var nødvendigt fordi der i mellemtiden var blevet konstrueret et nyt værktøj og at der nu kun krævedes en 3 millimeters fordybning i pladen. Fra tegnestuen hentede monteringsfolkene den tekniske tegner, der sammen med dem havde lavet det nye stykke værktøj. Han bekræftede at en fordybning i stedet for stansehullet ville være tilstrækkeligt.

Dernæst blev der sammen med en kleinsmed fra reparationsafdelingen skitseret en indretning, hvormed den ønskede fordybning i kassepladen kunne anbringes bagefter. Endelig udfærdigede den tekniske tegner på stående fod en tegning til kleinsmeden, som han kunne lave indretningen efter.

I mellemtiden havde presse- og stanseværket bekræftet overfor indkøberen, at der var blevet lavet en fejl hos underleverandøren, og at omkostningerne ved udbedringen af fejlen kunne modregnes på regeringen.

Da svejserne om eftermiddagen havde genoptaget arbejdet med den nye indretning, henvendte de sig til tidtageren i afdelingen for arbejdstilrettelægning og forlangte, at akkordtiden for kassen blev sat op fra 80 til 84 minutter på grund af det forøgede arbejde. Da indkøberen bekræftede, at de forøgede om- 
kostninger for denne serie ville blive betalt af presse- og stanseværket, havde tidtageren ingen betænkeligheder ved at forandre akkordtiden i overensstemmelse med svejserens krav.

Nogen tid senere benyttede den tekniske tegner en lejlighed til at gøre chefkonstruktøren bekendt med forandringen ved kassen og fik den opgave at udarbejde ændringerne ved kassepladerne for presse- og stanseværket samt foranledige indkøbsafdelingen til presse- og valseværket at forhandle sig frem til et prisnedslag for de følgende serier.

Dette hændelsesforløb havde ikke vakt nogen opsigt, hvis ikke virksomheden kort forinden havde fået en ny direktør, der i overensstemmelse med det gamle ord - »nye koste fejer bedst « - var besluttet på at gribe tøjlerne med fast hånd. Han havde beordret, at enhver ændring af akkorden i forvejen skulle forelægges ham til anerkendelse. Da han erfarede, at man i denne sag havde forsyndet sig mod hans forordning, tilkaldte han afdelingslederen og bebrejdede ham det: »De lader folkene tage ledelsen fra dem og fors $\varnothing$ mmer organisationen. « Hertil gjorde afdelingslederen gældende, at personalet havde udvist klogskab og initiativ og på ingen måde havde handlet letsindigt. Den kendsgerning at de kunne klare sådanne sager uden indblanding fra værkfører og arbejdsleder, medvirkede til at de selv kunne koncentrere deres arbejde helt og fuldt om udviklingen af en ny virksomhedsafdeling. Netop fordi personalet selvstændigt kunne mestre den gamle produktion, var det muligt for virksomhedsledelsen at tage fat på nye projekter.

Faktisk spiller samarbejdet mellem arbejdere og funktionærer på eget initiativ en stadig mere afgørende rolle i den moderne høj-produktive industri. Muligheden herfor beror på, at arbejdere og funktionærer sættes i gensidig forbindelse gennem produktionsprocessen. For dette industrielle samarbejde bruger sociologien begrebet »kooperation «. Kooperationens art og form samt dens intensitet afhænger af produktionsteknikken og arbejdsdelingens udformning (»Gestalt der Arbeitsteilung «).

I maskinfabrikker, der fremstiller enkelte maskiner efter særlige konstruktioner, koopererer specialister, konstruktører, håndværkere eller maskinarbejdere med deres specifikke viden og deres specifikke instrumenter, værktøj og maskiner. Kooperationen sker enten direkte ved personlig rådslagning eller inddirekte formidlet gennem konstruktionsplaner, tegninger, tidsplaner, materialeopstilling o.s.v. Man koopererer anderledes i virksomheder der fremstiller masseartikler, halvfabrikata eller kemikalier, kuglelejer, plader eller kunstgummi. Her er produktionsprocessen nøje fastlagt. Ved fremstilling af en række maskinaggregater, apparater og transportmidler koopererer maskinpassere, processtyringspersonel, kontrolfolk, reparationshåndværkere og teknikere. Mellem sig har de maskineriet, som de styrer på forskellige steder, regulerer, kontrollerer og holder i gang, idet de fjerner driftsforstyrrelser. Deres samarbejde er således næppe direkte, af personlig karakter, men snarere formidlet af maskineriet. 
Personalet ved et samlebånd, hvor de samme produkter fremstilles i massevis under en høj grad af arbejdsdeling, koopererer ligeledes. Men deres samarbejde har en stiv, mekanisk form, fordi et sådant maskineri tvinger den enkelte til at udføre bestemte efter art og tid fastlagte håndgreb i stadig gentagelse. Samarbejde på eget initiativ har kun ringe spillerum ved samlebåndet. Men samlebåndet er kun det afsluttende trin i en produktionsproces, som begynder med udvikling og konstruktion af samlebåndsartiklen, og udvikling, konstruktion og bygning af maskineriet til fremstilling af enkeltdelene og deres montering. Denne fase af produktionsprocessen er imidlertid kendetegnet ved en højintensiv kooperation mellem ingeniører, teknikere, håndværkere og maskinarbejdere, i hvilken deltagernes skabende initiativ spiller en afgørende rolle.

Fejlagtigt anser man stadigvæk kun det stive, mekaniske arbejde ved massefremstilling af enkeltdele og ved samlebåndene som karakteristisk for vor moderne industri. I virkeligheden er det betegnende for den moderne højproduktive industri, at det stive, mekaniske arbejde i hurtig takt afløses af den automatiserede produktion som i stigende grad er afhængig af den selvstændige ansvarsfulde kooperation mellem maskinpassere, teknikere og håndværkere.

\section{Forandringer på produktionssiden}

Forandringerne i samfundsforholdene forårsages generelt af udviklingen af produktivkræfterne, som til stadighed udfordrer menneskene til at indgå nye relationer med hinanden i produktionen. Når dette er sket, skabes der påny mulighed for udvikling af produktivkræfterne. Menneskenes forhold til hinanden i produktionsprocessen er således i sig selv en produktionsfaktor.

Den overordnede og særligt iøjnefaldende udvikling af produktivkræfterne omfatter udviklingen af maskiner og apparater, kommunikationsmidler og fabriksbygninger, råstoffer og produktionsmaterialer o.s.v., altså udviklingen af de rent håndgribelige tingslige produktivkræfter. For at kunne sætte disse i drift og videreudvikle dem, fordres der en tilsvarende udvikling af kvalifikationerne hos arbejdere og funktionærer som menneskelig subjektiv produktivkraft. Udviklingen af de tingslige og menneskeligt - subjektive produktivkræfter foregår altså sideløbende og i nøje sammenhæng med udviklingen af naturvidenskaben og den tekniske videnskab.

Medens de tingslige produktionsmidler under kapitalistiske forhold i hovedsagen er i kapitalisternes privatbesiddelse, er de forskellige produktionskvalifikationer i de enkelte arbejderes og funktionærers individuelle besiddelse og afhængig af den individuelle konstitution, erhvervet og videreudviklet gennem skoling og erfaring. Ejeren må for at kunne anvende sine tingslige produktionsmidler produktivt, købe de nødvendige menneskeligt - subjektive produktionskvalifikationer, d.v.s. ansætte arbejdere og funktionærer og betale dem løn. Derudover må han skabe en organisation for at kunne føre de to slags produktivkræfter, som han nu råder over, sammen til en bedriftsmæssig produktion. 
Men den kapitalistiske produktions organisation har ikke kun den funktion at udvikle, lede og overvåge produktionen, at ansætte de enkelte arbejdere og funktionærer og at foreskrive arbejdsgangen. Den har også en anden funktion, nemlig at udøve disciplin over arbejdere og funktionærer og at sørge for, at de produkter, der skabes af disse, til stadighed tilegnes de kapitalistiske ejere. I denne anden funktion er den altså de kapitalistiske ejeres herredømmeinstrument overfor arbejdere og funktionærer. Organisationen er derfor som ethvert herredømme opbygget hierarkisk: tidligere med ejeren selv på toppen, men nu almindeligvis med en direktør, og med afdelingsledere, værkførere og formænd på de lavere trin.

Som bekendt kan 10 arbejdere få en jernbaneskinne anbragt i den $\emptyset$ nskede stilling ved samtidig at udføre den samme bevægelse, medens de som enkelt og ukoordineret arbejdende ikke formår at bevæge skinnen. Flere arbejdere, der arbejder fornuftigt sammen, besidder i fællesskab en væsentlig højere arbejdsevne og når i fællesskab en højere arbejdsydelse end summen af deres individuelle arbejdsevner og ydelser udgør. Det samme gælder ifølge sagens natur for funktionærerne. Det var fra begyndelsen karakteristisk for den kapitalistiske produktion, at den ekstra produktivkraft, som blev skabt gennem kooperation, organiseredes i denne. Med arbejdsdelingen nåede kooperationen et endnu højere niveau.

Arbejdere og funktionærer i titusindvis sammensluttedes endelig i storforetagender med arbejdsdelt kooperation i ensartede produktionsprocesser. Organiseret af virksomhedshierarkiet opstod der således mægtige produktivkræfter. Men da virksomhedshierarkierne altid optræder som de kapitalistiske ejeres organer, fremtræder den af dem organiserede produktivkraft som de kapitalistiske ejeres præstation. Marx analyserer dette skin i »Kapitalen« således:

»Kapitalisten betaler derfor værdien af 100 selvstændige arbejdskræfter, men han betaler ikke de hundredes kombinerede arbejdskraft [...] Den produktivkraft, som arbejderen udvikler som samfundsmæssig arbejder, er derfor kapitalens produktivkraft. Arbejdets samfundsmæssige produktivkraft udvikler sig uden vederlag, så snart arbejderne er stillet under bestemte betingelser, og kapitalen stiller dem under disse betingelser. Da arbejdets samfundsmæssige produktivkraft ikke koster kapitalen noget, og da den på den anden side ikke bliver udviklet af arbejderen, før hans arbejde tilhører kapitalen, fremtræder den som en produktivkraft, der er kapitalen naturgivet, som kapitalens iboende produktivkraft «. ${ }^{1}$

Under presset af den kapitalistiske konkurrence, den uophørligt drivende kraft mod stigning af den industrielle produktivitet og senest også under trykket af konkurrencen mellem de politiske systemer, er en stadig og magtfuld udvikling af alle produktivkræfter en tvingende nødvendighed for kapitalistens og kapitalismens selvopretholdelse. Industriens maskiner og apparater bliver stadig mere komplicerede og repræsenterer en stadig højere værdi. For at kunne mestre disse nyopståede komplicerede produktionsprocesser er arbejdere og funktionærer tvunget til ikke alene at udvikle evnen til at udføre snævert begrænsede, 
højtspecialiserede delarbejder, de må også parre denne færdighed med evnen til at udføre disse delarbejder i stadig, gensidig kooperation med deres kolleger.

Under disse produktionsbetingelser får virksomhedshierakiet stadig færre muligheder for gennem ordre, anvisninger, forskrifter eller normer at bestemme den enkeltes arbejde. Den enkelte må i stadigt højere grad handle selvstændigt og udvikle personligt initiativ i sit arbejde. Virksomhedshierarkiet må for ikke at hæmme produktivitetsudviklingen give plads for dette personlige initiativ. Men i samme grad som hierarkiet mister kontrollen med den enkelte arbejders konkrete arbejde, taber det evnen til at udføre sin produktive funktion: nemlig at være organisator af kooperationen. Derfor viser tendensen sig til, at ledelsen af og opsynet med, ja endog selve planlægningen af produktionsprocessen går fra hierarkiet over til arbejderne i produktionen og de ansatte på tegnestuerne og i administrationen. Arbejdere og funktionærer vinder igennem deres kooperation en indsigt i produktionsbetingelserne, som hierarkiet er udelukket fra, og de kan på denne baggrund selv træffe de nødvendige afgørelser til fremme for produktiviteten.

På den måde skabes der i de moderne, højproduktive virksomheder, særligt i produktionsmiddelindustrien, en ny slags kooperation, en kooperation, som ikke er organiseret af hierarkiet, som altså ikke er fremmed - bestemt, men skabt af arbejdere og funktionærer i et skabende kollektivinitiativ til bestridelse af den nye teknik. De mest moderne industriforetagender er altså ikke kun beroende på den produktivkraft, der består i det moderne maskineri og de nye arbejdskvalifikationer, som den enkelte arbejder og funktionær er i besiddelse af men i lige så høj grad beroende på den produktivkraft, som denne nye type kooperation udgør.

Nogle begivenheder fra den sidste tid illustrerer denne kendsgerning. I 1957, da stålindustrien i Ruhrområdet p.g.a. afsætningsvanskeligheder nedsatte produktionen med $40 \%$, fandt der kun ganske få afskedigelser sted. At det kostede dyrt at holde på arbejdsstaben i deres højproduktive virksomheder afskrækkede ikke industriherrerne. Arbejdere og en hel del funktionærer, der ikke mere kunne anvendes i produktionen »beskæftigedes « med produktionen uvedkommende ting, eller man indførte deltidsarbejde. I denne periode med afsætningsvanskeligheder var alle højproduktive virksomheder, der var ramt af krisen meget ivrige for i det mindste at beholde »den faste kerne « altså den del af de ansatte, der arbejdede i den mest intensive kooperation med hinanden. Anderledes så det ud i mindre moderne og mindre produktive virksomheder. De industriherrer fra textil - og bjergværksindustrien, der var trukket med ind i krisen, veg ikke tilbage for masseafskedigelser, heller ikke af den faste kerne.

Monopolmanagernes handlemåde skyldtes ikke så meget deres kristelige næstekærlighed, eller deres »menneskekærlighed «, eller deres »menneskelige forståelse «, motiver som de lod deres hofjournalister tilskrive sig, men fremfor alt deres bekymring m.h.t. at beholde det »indarbejdede mandskab «. De er klar over, at den kooperation, der er udviklet af arbejdere og funktionærer ved genopbygningen af industrien efter 1945, repræsenterer en produktivkraft, som de 
ikke den ene dag kan afskedige og den næste dag stampe op af jorden. De ved bedre end personalet selv, at de ikke kan takke deres virksomhedshierarkiers organisationstalent for dette »indarbejdede personale «, men at det skyldes arbejdernes og funktionærernes eget initiativ.

Men også arbejdere og funktionærer begynder at blive klar over, at kooperationen er deres egen produktivkraft. Det har bl.a. vist sig ved de »arbejd langsomt « (go - slow) strejkeaktioner, som italienske og engelske industriarbejdere har iværksat. Denne strejketaktik indebærer, at der kun arbejdes efter hierarkiets forskrifter og anvisninger uden eget initiativ og uden selvstændig handling. Mandskabet stiller ganske vist som før sin med løn og gager betalte personlige arbejdskraft og dygtighed til rådighed for kapitalen, men unddrager den den produktivkraft, der er udsprunget af deres eget initiativ og deres eget skabende samarbejde.

Denne nye form for kooperation har skabt et særdeles intensivt forhold mellem arbejdere og funktionærer. De bliver til selvstændige, selvbevidste arbejdsstyrker, til det moderne samfunds organiserede basis. Industrielle kooperationer af denne art vil vi derfor - for at adskille dem fra den af det kapitalistiske hierarkiorganiserede kooperation - betegnes som bedriftskooperation. (»Belegschaftskooperation «).

Med dannelsen af bedriftskooperationen skabes nye betingelser for klassekampen i virksomheden. »Stampersonalets « stærke selvbevidsthed, opslutningen om fagforeningskravet om medbestemmelse i alle spørgsmål vedrørende virksomheden, den i personalet for det meste spontant opståede fordring om lønkompensation for deltidsarbejde og i særlig grad »arbejd langsomt « strejkeaktionerne har gjort klart, at personalet under bestemte betingelser begyndte at behandle kooperationen helt som deres egen kollektive produktivkraft. Hvis personalet imidlertid ikke mere opfatter sig som en produktivkraft, som kapitalen ganske naturligt besidder, som dens immanente produktivkraft, men som sin egen ejendom, som en i personalet immanent produktivkraft, så kan det ikke undgås, at personalet kun vil stille denne, sin egen produktivkraft til rådighed for kapitalsiden på ganske bestemte betingelser. Det vil i almindelighed være betingelser af $\varnothing$ konomisk art, som dog i sin helhed vil have et politisk indhold, der vil have en revolutionerende indflydelse på den kapitalistiske samfundsorden.

\section{Forandringer på ejendomssiden}

Lad os nu vende os mod de kapitalistiske produktionsforholds anden side ejendomssiden. Produktivkræfternes udvikling, som vi har talt om, har ikke kun bevirket forandringer i relationerne mellem de producerende arbejdere og funktionærer men også de så ofte diskuterede omordninger på ejendomssiden.

Den kapitalistiske udviklings klassiske fase stod i den selvstændige industrielle virksomhedsdrivendes tegn - i industrikapitalistens tegn. Han var både personlig ejer af produktionsmidlerne og som sådan tilegner af produktet, udbytter af arbejdere og funktionærer og leder af produktionsprocessen og som sådan 
medproducerende - »fungerende kapitalist «. Storindustriens udvikling og specielt sværindustriens mammutforetagender erstattede industrikapitalisten, som hverken personligt rådede over den nu nødvendige finanskraft og heller ikke var i stand til personligt at lede den stadig mere komplicerede produktionsproces.

I og med skabelsen af kapitalselskaberne blev industrikapitalisterne opdelt i to persongrupper med forskellig samfundsmæssige funktion: ejendomsforvaltere og ejere. Ejendomsforvalterne leder nu produktionsprocessen i virksomhederne og er således medprocucenter, men på den anden side tilegner de sig produkterne til ejerne, køber arbejdskraften og udøver disciplinærmagt over denne. Ejerne er frakoblet produktionsprocessen. De modtager den af ejendomsforvalterne opnåede profit og den del af kapitalen, der kommer tilbage i form af afskrivninger. De afgør, hvor stor en del af profitten og kapitaltilbagestrømningen, der skal anvendes til nyinvesteringer, i hvilke industriforetagender de skal indgå, og hvor stor en del der skal indgå i det personlige konsum.

Mellem ejendomsforvalterne og ejerne - i aktieselskabslovens forstand mellem bestyrelsesmedlemmerne og aktionærerne - gør der sig fra begyndelsen en interessemodsætning gældende, som tidligere blev udkæmpet i industrikapitalistens eget hjerte og derfor ikke kom frem. Denne interessemodsætning udkrystalliserer sig i to spørgsmål: Hvor stor skal det konsumfond være, der tilfalder ejendomsforvalterne i form af gager og tantiemer og ejerne i form af aktieudbytte? I hvilke industrivirksomheder bør der investeres? I dem der ledes af ejendomsforvalterne eller i fremmede foretagender? For at udligne interessemodsætningen mellem ejendomsforvalterne og ejerne bliver der indsat en tredie presongruppe - $\mathrm{i}$ aktieselskabsterminologi kaldet bestyrelsen. Men de tre persongrupper, som er trådt i stedet for industrikapitalisterne, står ikke i noget harmonisk forhold til hinanden på trods af den retslige institutionalisering som aktieselskaber og $\mathrm{GmbH}$ [Gesellschaft mit beschränkter Haftung] og kommanditselskaber. Modsætningen mellem dem, som er blevet forstærket ved produktivkræfternes udvikling, der jo kræver en fortsat koncentration og centralisering af kapitalen ved hjælp af kreditvæsenet og bankerne, forårsager en stadig forskydning af magt og indflydelse.

Man må erindre, at kapitalselskaber kan dannes af et yderst forskelligt antal ejere af forskellig styrke. I et aktieselskab med en kapital på 500 millioner med 500.000 tusindkroners-aktier kan forholdet mellem aktionærerne meget let forholde sig som 1 til 100.000 eller 1 til 200.000. Men desuden ejes størstedelen af aktierne i de vigtigste aktieselskaber af andre kapitalselskaber, særligt af holdingselskaber, koncerner og banker, der igen på deres side har kapitalselskaber som hovedaktionærer. Man kan derfor fastslå, at det personlige ejerskab af enkelte storindustrivirksomheder kun undtagelsesvis kan bestemmes. Derimod kunne man hos skattevæsenet finde ud af hvem de personlige ejere er, som storindustrien, vort samfunds materialle grundlag, i fællesskab tilhører. Den består af nogle hundrede virksomheder af forskellig art og størrelse som via arbejdsdeling står i forbindelse med hinanden. Men de enkelte ejeres andel 
i den samlede ejendom er så forskellig i størrelse, at der ikke kan være tale om fællesskab imellem dem. Denne gruppe består af nogle få milliardærer, nogle hundrede tidobbelte millionærer, titusinder med middelstor eller lille formue og som en nydannelse: millioner af småsparere, der formelt er blevet medejere af storindustrien gennem investeringsbeviser og folkeaktier.

Denne grundliggende forskellighed mellem de fælles ejere kommer til udtryk i kampen om pladserne i bestyrelsen. I de store kapitalselskabers bestyrelse sidder milliardærerne og millionærerne undertiden selv, men oftere deres retsligt befuldmægtigede eller repræsentanter for andre kapitalselskaber, særligt for banker og koncerner. Den store masse af ejere er udelukket af bestyrelsen, selvom de også tilsammen repræsenterede mere end halvdelen af aktiekapitalen, fordi de er splittede.

I bestyrelserne - ligesom i administrationsledelserne - har ejendomsforvalterne overvægt - da jo også milliardærernes og millionærernes befuldmægtigede er ejendomsforvaltere. I deres rolle som formidler mellem ejere og ejendomsforvaltere hælder de naturnødvendigt mod ejendomsforvalterne, med hvem de skal holde opsigt. Udviklingen er kendetegnet af, at bestyrelsernes persongruppe og administrationsledelsens persongruppe blander sig med hinanden, gensidigt udnævner hinanden og smelter sammen. I fællesskab skaffer de administrationen absolut overvægt over ejendommen. I tidens løb forandrer de forenede bestyrelsesmedlemmer og ledelsesmedlemmer deres position som ejendomsforvaltere til en ejerposition, en proces der i Amerika efter en bog af Burnham kaldes: »Direktørernes Revolution« (The Management Revolution).

En sådan, på sin vis kold revolution forudsætter, at ejendomsforvalterne, takket være den enorme industrielle produktivitetsstigning, råder over hidtil ukendte profitmasser. Således kan de få ejerne til at affinde sig med en regelmæssig, garanteret dividende, betænke storaktionærerne med særbegunstigelser som f.eks. bestyrelsestantiemer, eller lade banker og koncerner opkøbe aktionærernes aktier til meget høje kurser. Denne forretningsmåde bærer det smukke navn »kurspleje« (»Kurspflege«). Den gør bankerne til storaktionærer $\mathrm{i}$ industrikoncernerne, koncernerne til aktionærer i bankerne, datterselskaber til aktionærer i moderselskaberne og koncernerne til storaktionærer hos hinanden.

Det er ikke nødvendigt med sådanne manipulationer og gensidig delagtiggørelse uophørligt at købe de enkelte personlige kapitalejere ud. Afgørende for denne forvandling af ejendomsforvalterpositionen til ejendomspositionen er langt snarere, at de førende forvaltningsledelser og bestyrelser, som gerne lader sig omtale som »Økonomiens mænd «, men som vi nøgternt kalder bank- og koncernfolk, bringer profitten og kapitaltilbagestrømningen fra storindustrien under deres kontrol og derved stadigt udvider deres magtområde. Denne såkaldte »selvfinansiering « af industrien er i virkeligheden bank- og koncernfolkenes selvfinansiering ud af den kapital, der er sat under deres forvaltning, og som ifølge det privatkapitalistiske grundprincip og retsopfattelse tilkom ejerne. 
Koncern- og bankfolkenes magt over de personlige ejere er allerede så stor, at de uden betænkelighed sætter sig ud over en privatkapitalistisk legitimering af deres magt. Dette kommer til udtryk i de kyniske svar, med hvilke man på generalforsamlingerne affærdiger opponenter, hvis de $\mathrm{i}$ aktionærermassens navn rejser indvendinger mod selvfinansieringen, kritiserer bestyrelsens og aktionærernes lønninger og andre indtægter og fremsætter deres retmæssige krav på en dividende, der svarer til de opnåede fortjenester. Bank- og koncernfolkene plejer så med ironisk høflighed at foreslå opponenterne at sælge deres aktier, hvis bestyrelsens ledelse ikke passer dem. De kan tillade sig sådanne forslag, fordi kapitalejerne, om de nu er aktionærer i dette eller hint selskab, om de investerer deres kapital i banker, industrikoncerner, forsikringsselskaber eller i landarealer i indeller udland, til stadighed forbliver underkastet de forenede bank- og koncernfolk.

\section{Bank- og koncernfolkene som økonomiske planlæggere}

Den forvandling fra ejendomsforvalterfunktion til ejendomsfunktion, der til stadighed finder sted, viser tydeligt, at den kapitalistiske ejendomsret over produktionsmidlerne $\mathrm{i}$ industrien i stor udstrækning nu kun er et fiktivt slør, som bankog koncernfolkene iklæder deres operationer med andres ejendom. Jo tyndere dette slør bliver, jo mindre kan det skjule den kendsgerning, at bank- og koncernfolkene hverken af den kapitalistiske ejendomsret eller gennem deres præstation m.h.t. ledelse og udvikling af industrien er berettiget til at udøve denne magt. Thi det er ikke dem, men derimod virksomhedsdirektørerne i samarbejde med forskere, videnskabsmænd, opfindere, konstruktører o.s.v., der på eget ansvar og eget initiativ leder og udvikler industrien, skønt det kunne se ud, som om de som ansatte og lønmodtagere kun udfører bank- og koncernfolkenes ordrer.

Derimod er det bank- og koncernfolkenes opgave at kontrollere, sammenfatte og reinvestere profitter og kapitaltilbagestrømninger fra hele storindustrien. De bestemmer investeringerne og planlægger i national målestok de fremtidige investeringers sammensætning og omfang. Det er deres samfundsmæssige funktion. Herfor er de ansvarlige og herfor må de kraves til regnskab. Men netop denne funktion, som de virkelig udfører, vil bank- og koncernfolkene ikke vide noget af overfor offentligheden. Skønt de for længst er gået over til at dirigere markedet, henviser de ved hver lejlighed til, at markedet har sine egne love, som faktisk ikke mere eksisterer. Således prøver de fra begyndelsen at undsige sig deres ansvar for det tilfælde, at de med deres investeringer og planlægning, som har sine rødder i deres blinde stræben efter profit, personlig rigdom og personlig magt, skulle have fremmanet nye kriser og katastrofer.

\section{Virksomhedspolitik på basis af bedriftskooperation}

I de store industriforetagender (man behøver blot at tænke på Krupp-foretagenderne) har kapitalsiden allerede i årtier ført en virksomhedspolitik, som gør regning på bedriftskooperation som produktivkraft. Det er bemærkelsesværdigt at netop 
den senere fascistiske virksomhedspolitik gav bedrifts-kooperationen store udviklingsmuligheder. Det kunne man tillade sig, fordi ødelæggelsen af de selvstændige arbejderorganisationer og knæsættelsen af »Førerprincippet « forvandlede virksomhedshierakiets herredømme over personalet til et direkte politisk herredømme og gjorde virksomhedshierakiet til et umiddelbart organ for det politiske herredømme. Kapitalsidens direktions- og disciplinærmagt var dermed sikret fuldt ud. Således kunne man først under indtryk af arbejdsløshedens afskaffelse, og dernæst på grund af sejrspsykosen og til sidst på grund af holdud-psykosen som også arbejderne til en hvis grad lå under for, for en tid stille bedriftskooperationens produktivkraft helt og fuldt i krigsindustriens og den imperialistiske ekspansions tjeneste. Efter krigen hævede den kapitalistiske virksomhedspolitik sig ved hjælp af udnyttelsen af de erfaringer, der især var gjort i U. S. A. med »human relations «- politikken og ved hjælp af industrisociologiske- og virksomhedspsykologiske undersøgelser op på et højere, videnskabeligt niveau, det svarede til vundet verdensberømmelse som »det tyske økonomiske mirakel« Wirtschaftswunder).

I modsætning hertil har de producerendes organisationer, fagforeninger og partier, ikke indset bedriftskooperationens betydning, hverken som produktivkraft og/eller som potentiel politisk kraft. Som følge heraf fastholdt de virksomhedspolitiske forestillinger, som ville have svaret til et tidligere trin i den industrielle udvikling, men som under de nye betingelser overfor kapitalen, hvis virksomhedspolitik smart udnyttede bedriftskooperationen, var fuldkommen forfejlet. Til sidst blev virksomhedspolitik i stigende grad overladt til bedriftsrådenes personlige erfaringer, fornemmelser og initiativer. Som oftest blev energien udtømt i mere eller mindre vellykkede forsvarsaktioner overfor kapitalsidens virksomhedspolitiske angreb. På grund af fagforeningernes og partiernes undladelsessynder og usystematisk gennemførte virksomhedspolitik, er arbejderne blevet fremmedgjorte overfor disse organisationer, og er virksomhedspolitisk set blevet trængt i baggrunden og i stor udstrækning afpolitiseret.

En eventuel virksomhedspolitik på basis af bedriftskooperationen må have følgende mål:

1) At fremskynde udviklingen af bedriftskooperationen og samtidig inddrage nogle af virksomhedshierakiets medlemmer.

2) Systematisk at fortrænge den del af hierakiet som ikke kan inddrages i produktionsprocessen, for at gøre det uvirksomt som kapitalens magtinstrument over personalet.

3) At opnå den størst mulige del af personalets medvirken i alle aktioner. Dette er påkrævet, for at personalet skal kunne blive sig bevidst, at det er et bedriftskollektiv og dermed en grundenhed i samfundet.

4) At udnytte det modsætningsforhold, som kapitalsidens virksomhedspolitik uvægerligt hele tiden må forvikle sig i, fordi den ikke kan tillade, at virksomhedshierakiets disciplinær- og ledelsesmagt over personalet bliver svækket, og på den anden side må give bedriftskooperationen som produktivkraft fri bane. 
I den konflikt mellem modsatte virksomhedspolitiske linier arbejder udviklingstendenserne mod kapitalsiden. Den må svømme med strømmen og befinder sig i en forsvarsposition. Men den har den borgerlige ret, som sikres af de statslige magtorganer, på sin side. Der står uindskrænkede pengemidler til dens rådighed, ved hjælp af hvilke den udbygger sine forsvarsværker. I kraft af sin pengemagt behersker den enevældigt de store medier, der styrer den offentlige meningsdannelse. Den forsørger en hær af sociologer, psykologer, menings- og arbejdsforskere, nationaløkonomer og drifts $\varnothing$ konomer, journalister, designere, filosoffer og lignende specialister, der i videnskabelige institutter gør tjeneste som den kapitalistiske virksomhedspolitiks generalstab, og som uddanner de praktiske virksomhedspolitikere. Som umiddelbart og til stadighed arbejdende instrument håndhæver den desuden disciplinær- og ledelsesmagten over de enkelte personalemedlemmer og særligt over hierakiets medlemmer. Den har, ved hjælp af privilegier af forskellig art, indflydelse på enkelte personalemedlemmers adfærd. I yderste nødsfald kan den afskedige medlemmer af personalet eller hierakiet.

I modsætning hertil består personalets styrke deri, at de virksomhedspolitisk set kan svømme med strømmen i udviklingstendenserne, og at de befinder sig i en angrebsposition. Desuden har det bestemte rettigheder såsom retten til at danne foreninger, strejkerettet, forhandlingsretten og virksomhedsforfatningsretten (Betriebsverfassungsrecht) på sin side, rettigheder der i arbejderbevægelsens tidligere kampe er blevet erobret.

\section{Lønforskelle i virksomhedspolitikken}

Vi kommer nu til nogle praktiske anvisninger på en konkret virksomhedspolitik, baseret på bedriftskooperationen. Det må først og fremmest dreje sig om at videreudvikle bedriftskooperationen som sådan, og gøre den bevidst, og for at kunne det, er det fremfor alt vigtigt at overvinde de hæmninger som forstyrrer og forringer personalets enhed. Sådanne hæmninger bliver til dels kunstigt skabt, til dels forstærket af kapitalsidens virksomhedspolitik. Et af dens mest effektive midler til at holde konkurrencen indenfor personalet levende og til at undergrave personalets enhed er den måde, på hvilken den samlede løn fordeles på de forskellige personalegrupper og - medlemmer. Det ene medlem eller den ene gruppe får højere løn end det andet medlem eller gruppe. Denne såkaldte løndifferentiering, den kendsgerning, at den ene personalegruppe, den ene kollega bliver begunstiget eller forfordelt i forhold til den anden gruppe eller kollega, turde være et af de mest debaterede spørgsmål i alle virksomheder, men det er samtidig også det spørgsmål, der udgør en af de største hæmsko for bedriftskooperationens udvikling og for bevidstheden derom.

Til lønoverenskomstaftaler i industrien kan man i dag anvende to forskellige retsgrundlag. Overfor arbejdernes og funktionærernes forenings-, forhandlingsog virksomhedsforfatningsret står den borgerlige ret. Ifølge den borgerlige ret findes der kun individuelle arbejdskontrakter, og de enkelte arbejderes og funk- 
tionæres løn bliver aftalt individuelt med kapitalsiden, i skikkelse af virksomhedsdirektøren eller personaleafdelingerne. Den individuelle arbejdskontrakt beror på, at den enkelte arbejder eller funktionær frit kan vælge til hvilke kapitalister han vil sælge sin arbejdskraft, som han under alle omstændigheder bliver nødt til at sælge for at kunne opretholde livet. I modsætning hertil er arbejdernes og funktionærernes forenings- og virksomhedsforfatningsret resultater af arbejderbevægelsens kamp. På grundlag af disse rettigheder slutter fagforeningerne og bedriftsrådene kollektive lønaftaler, som ganske vist ikke ophæver de borgerlige arbejdskontrakter, men hvis indhold dog med bindende virkning er fastlagt, og som for enhver ansættelse automatisk bliver gyldig for begge parter.

Alt efter hvilket retsgrundlag man går ud fra, bliver konsekvenserne forskellige, ja ligefrem modsatte, for de producerendes position overfor hierakiet. Den borgerlige ret er en virkningsfuld støtte for virksomhedshierakiets disciplinær- og ledelsesmagt, medens forhandlings- og virksomhedsforfatningsretten betyder en principiel indskrænkning af disciplinær- og le delsesmagten. Hvis arbejderne og funktionærerne ved arbejdskontraktens afslutning står enkeltvis overfor hierakiet, kan de ikke andet end at anerkende hierakiets diciplinær- og ledelsesmagt og må underkaste sig den. De må i givet fald finde sig i, at den aftalte løn i nogen henseende bliver gjort afhængig af deres føjelighed overfor hierakiet. Men fagforeningen står overfor kapitalsiden, og bedriftsrådet står overfor hierakiet som forhandlingspartner, der forhandler i kollektivets navn. Indenfor de kollektive aftalers rammer er der ikke plads til nogen anerkendelse af hierakiets diciplinær- og ledelsesmagt, da denne kun fungerer over for den enkelte, og på baggrund af at den borgerlige ret kun kan virke overfor den enkelte. Ganske vist ophæver overenskomstaftalen ikke hierakiets disciplinærog ledelsesmagt. Denne støttes stadigvæk af retten til at nægte at ansætte bestemte personer, eller til at afskedige bestemte personalemedlemmer, til at anvise den enkelte bestemte arbejdsområder, at forfremme eller degradere ham. Men den mest virkningsfulde støtte går tabt, når lønspørgsmålet ikke kan anvendes som pressions- og magtmiddel mod den enkelte.

Kapitalsiden affinder sig forståeligvis ikke med denne stilling. Den bestræber sig på at omgå og udhule den kollektive aftaleret, især bedriftsrådenes, for i stedet at gøre den borgerlige ret gældende. Den skyr f.eks. ingen udgifter for at slutte aftaler med enkelte personalemedlemmer af enhver art (der går udover overenskomsten eller udover den lokale aftale) om ekstrabetalinger og begunstigelser for at få dem til at distancere sig fra kollektivet og vinde dem som hierakiets tillidsfolk.

Således har den lønmæssige virksomhedspolitik den opgave at forsvare de rettigheder, som disciplinær- og ledelsesmagten prøver at indskrænke. Her kan arbejderne hovedsageligt st $\varnothing t t e$ sig til $\S 56$ og 49 i virksomhedsforfatningsloven. I $§ 56$ fastslås bedriftsrådets ret til at have medbestemmelse ved reguleringen af akkordlønninger og ved fastlæggelsen af aflønningsprincipperne og til at afslutte virksomhedsaftaler inden for rammerne af de af fagforeningerne 
opnåede overenskomster. I $\S 49$ pålægges det virksomhedsdirektørerne og virksomhedshierakiet tillidsfuldt og til virksomhedens og personalets bedste at samarbejde med bedriftsrådet, og at undgå alle handlinger, der kunne bringe arbejdet og freden på virksomheden i fare samt at forhandle med bedriftsrådet om alle stridsspørgsmål med oprigtig vilje til at opnå enighed.

Imidlertid kan bedriftsrådet ikke ved hjælp af arbejdsretten tvinge virksomhedshierakiet til at anerkende disse rettigheder eller til at opfylde disse pligter. Arbejdsretten kan ikke engang fradømme en af kapitalen befuldmægtiget hans »ret til at praktisere«. Kapitalsiden kan kun blive dømt til at betale erstatning. Derfor kunne det meget vel tænkes, at en virksomhedsdirektion, der ikke viger tilbage for at betale en sådan erstatning, ville sætte sig ud over aftale- og virksomhedsforfatningsretten og vilkårligt fastsætte lønninger i overensstemmelse med den borgerlige ret og deres interesse $i$ at opretholde en uindskrænket disciplinær- og ledelsesmagt. Men derved ville de miskreditere sig i offentlighedens $\varnothing j n e$, undergrave bedriftskooperationen som produktivkraft og derved til sidst miste deres konkurrenceevne.

Derfor er det vigtigt for bedriftsrådene at vide, at de i den sidste ende ikke med hjælp fra arbejdsretten kan forsvare aftale- og virksomhedsforfatningsretten som en hvilken som helst anden positiv rettighed. Aftale- og virksomhedsforfatningsretten er resultater af arbejderbevægelsens kamp, og det afhænger stadig af arbejderbevægelsens styrke og kampvilje, i hvor høj grad denne ret skal kunne gøres gældende. Derfor må bedriftsrådene med personalet hjælp underst $\varnothing$ ttet af bedriftskooperationen - forsvare, udbygge og udvide denne ret.

At støtte bedriftskooperationens lønpolitik vil først og fremmest sige at: blotlægge og foretage en unders $\varnothing$ gelse af alle lønninger (inclusive bonuser, overarbejdsbetaling, andre særbetalinger og godtgørelser). Personalet må have et rigtigt billede af lønforholdene i virksomhederne for at kunne danne sig et indtryk af de eksisterende lønforskelle. I deres umiddelbare erfaringsområde, indenfor en afdeling eller et kontor, kender arbejderne og funktionærerne de kvalifikationer og præstationer, som de forskellige arbejdsområder kræver, og kan følgelig bedømme, hvilke lønforskelle mellem dem der er rimelige, og hvilke der stammer fra hierarkiets forgodtbefindende eller vilkårlighed. For det meste forholder det sig anderledes m.h.t. lønforskelle mellem afdelingerne og i hele virksomhedsområdet. Her mangler de nødvendige oplysninger ofte. Derfor gælder det om, at diskussionen om lønforskelle, som jo altid foregår, bringes ud i offentligheden og gøres saglig, idet man udnytter alle muligheder til at indformere personalet om de til de forskellige arbejder i de andre afdelinger nødvendige kvalifikationer og præstationer. Man kan kun billige de lønforskelle, som af personalet anses som sagligt set rimelige. Denne kamp for retfærdige lønprincipper skaber gode forudsætninger for en intensivering af bedriftskooperationer, for et kollegialt forhold mellem arbejdere og funktionærer og for at inddrage hierakiets medlemmer i bedriftskooperationen. 


\section{Personalets politik over for paternalisme i virksomheden}

Industrisociologer og virksomhedspsykologer anbefaler de store industriforetagender at gribe til en hel række foranstaltninger »til fremme af de menneskelige relationer « (»human relations « eller »et sundt klima på arbejdspladsen«. Banker og koncerner og deres direktører tager disse ideer op og gør dem til grundlag for deres arbejdspladspolitik, noget som under navnet »paternalisme « bekæmpes stærkt af den italienske fagbevægelse. Men også bedriftsrådene på arbejdspladsen griber ofte til disse ideer, når de stiller forslag om sociale forbedringer på arbejdspladsen og mobiliserer kollegerne for at få gennemført disse fordringer.

Når begge sider fører en sådan overensstemmende arbejdspladspolitik fører det til ganske bestemte resultater i form af et vist antal sociale foranstaltninger. På flere virksomheder har man således indført analytisk arbejdsvurdering for at undgå vilkårligheder i forbindelse med lønfastsættelsen, og det såkaldte forslagssystem indføres med præmiering af de forhøjede arbejdsydelser i forbindelse med den tekniske videreudvikling af produktionsgangen og produkterne. Man henstiller til hierarkiet at tage hensyn til de underordnedes menneskeværdighed og at anlægge en venlig omgangstone over for dem.

Man udgiver aviser, hvori personalet bliver underrettet om virksomhedens $\emptyset$ konomiske og tekniske problemer. Man hædrer jubilarer, arrangerer personaleudflugter og personalefester. I forbindelse med personalesygekasser oprettes der helbredskonsultation, rekonvalecenthjem og feriehuse. Inden for socialforsorgens rammer organiseres der en hjælpetjeneste for de ansattes syge koner. Man åbner børnehaver. På virksomhedens egne arealer stiller man sportspladser til rådighed. Sports- og fritidsforeninger oprettes nu og udstyres med lokaler, pengemidler og rekvisitter. Begavede og stræbsomme ansatte modtager stipendier til videreuddannelse og/eller til et studium. Man ansætter juridiske rådgivere, som også står til rådighed for de ansatte i private spørgsmål. Man er ikke mindst ivrig efter at forøge antallet af arbejderboliger, som de ansatte făr til en relativ billig leje, og som forkorter vejen til arbejdet og derved binder dem til virksomheden.

Spørger man sig, hvad der foranlediger kapitalsiden til disse ofte meget dyre foranstaltninger, så vil man opdage, at det hele kun er følgen af den centrale betydning man i den moderne industri tillægger bedriftskooperationen som produktivkraft og dermed som yderligere profitkilde. Øjensynlig sigter hele denne »trivsel på arbejdspladsen « - politik på enten direkte eller (som oftest) indirekte at fremme og begunstige bedriftskooperationen. For så vidt bedriftsrådene forstår at konvertere disse »trivselsfremmende foranstaltninger «, som kapitalsiden mere og mere ser sig tvunget til at benytte sig af, til egne krav, er disse bestræbelser for dem kun en fortsættelse af den gamle kamp om sociale forbedringer og gunstigere arbejdsbetingelser. I praksis bliver det til et socialpolitisk samarbejde mellem personalerepræsentationen og virksomhedshierarkiet, af hvilket kapitalsiden tilsyneladende har meget større gavn end personalet. Dette samarbejde, deroverfladisk betragtet - ligger inden for den reformistiske traditions grænser, 
åbenbarer først sit egentlige politiske indhold i det øjeblik man bliver klar over den social-revolutionære kraft, der ligger i selve bedriftskooperationen.

Diskussionen om disse sociale forbedringer inden for virksomheden drejer sig i dag i grunden ikke så meget om selve foranstaltningerne og ordningerne, men i langt højere grad om, hvilken af siderne der skal have kontrollen med foranstaltningerne og administrationen af ordningerne. Personalets repræsentanter har gjort den erfaring, at sociale forbedringer kun er til varig og entydig nytte for personalet, hvis det enten selv eller dets repræsentanter administrerer eller kontrollerer dem. Denne kamp om kontrollen afslører, at ganske vist er begge sider stærkt interesseret i gunstige betingelser for bedriftskooperationen, men at kapitalsiden $i$ denne forbindelse kun tænker på de muligheder for en for$\emptyset$ get og så vidt mulig gnidningsløs produktivkraft, der ligger heri, medens de for personalet først og fremmest er væsentlige i det omfang, de kan begrænse hierakiets disciplinære myndighed og styrke deres egen selvbevidsthed.

Som eksempel på hvorledes denne konflikt kan udvikle sig, kan vi tage en mellemstor maskinfabrik. Her var direktionen ensidigt - trods bedriftsrådets modstand - gået over til at betale arbejderne præmier for forslag til forbedringen i produktionen. Personalet blev nu så ivrigt for at stille forslag og indkassere præmier, at bedriftsrådet måtte opgive sin modstand, og til sidst indgik de på en aftale om oprettelse af en præmiefond på $1 / 2 \%$ af den samlede lønsum. Den skulle også stå til rådighed for funktionærers opfindelser og forslag. Fonden skulle forvaltes af et parittetisk udvalg. sammensat af et bedriftsrådsmedlem som formand, den tekniske direktør og lederen af reparationsafdelingen som repræsentanter for kapitalsiden samt 2 kolleger udpeget af forslagsstillerne. Hvert udvalgsmedlem kunne tildele det indsendte forslag fra 1-10 points, hvorved man som grundlag for bedømmelsen ikke skulle tage hensyn til den $\varnothing$ konomisk svært bedømmelige nytteeffekt for arbejdsgiveren, men til realiseringsmuligheden og til indsenderens særlige præstation. Det gennemsnitlige pointtal skulle afgøre forslagets værdi. For hvert point udbetales der straks $20 \mathrm{DM}$ som forpræmie. Bedriftsrådet offentliggjorde straks forslagenes værdi sammen med en kort beskrivelse af dem. En gang årligt afholdtes et extraordinært personalemøde, hvor de tre permanente udvalgsmedlemmer aflagde beretning. Mødet kunne ved flertalsbeslutning ændre det pointtal, hvormed forslagene var vurderet. Den rest der var tilbage i fonden ved årets slutning blev i henhold til pointtal fordelt mellem forslagsstillerne.

Det viste sig allerede det første år, at kapitalsidens fordele ved systemet var langt større end deres indskud i præmiefonden. Af denne grund karakteriserede nogle kolleger ikke med urette systemet som et udbytningsinstrument og krævede det afskaffet. På den anden side havde kommissionsarbejdet, offentliggørelsen og diskussionerne om opfindelserne og forbedringsforslagene samt deltagelsen af mange teknikere og handelsfunktionærerne gjort det klart for personalet, hvad deres ideer og initiativer betød for foretagendets udvikling og derved i afgørende grad styrket deres selvbevidsthed. 
For at dæmpe kritikken forpligtede direktøren sig nu til at give tillægspræmien af samme størrelsesorden som fondens til de forbedringsforslag, der efter hans egen opfattelse var særlig værdifulde for virksomheden. Personalet var imidlertid klar over, at de og udvalget derved ville miste kontrollen over virksomhedens forslagssystem, og at den i det væsentligste ville overgå til direktøren og hans hierarki. De forlangte enstemmigt og sammen med de funktionærer og medlemmer af hierarkiet, der i hovedsagen ville have nydt godt af tillægspræmierne - at de tillægspræmier, som direktøren havde stillet i udsigt, skulle lægges til præmiefonden. Ikke alene fordobledes præmiefonden ved gennemførelsen af denne beslutning, men personalets selvbevidsthed styrkedes yderligere.

Utvivlsomt betød det for kapitalsiden en forhøjelse af produktiviteten og profitten, men den måtte til gengæld give afkald på en del af hierarkiets magt.

\section{Industrisociologien om kooperationen og dens konflikt med hierarkiet}

Det moderne industriarbejdes udpræget kooperative karakter, som er udgangspunkt for det her skrevne, er påny blevet stærkt fremhævet af de yngre tyske industrisociologer. 1957 offentliggjorde gruppen, Popitz, Bahrdt, Jüres, Kesting første del af deres »Sociologiske undersøgelse i Metalværker « under titlen Technik und Industriearbeit (forlaget Siebech-Mohr, Tübingen). Udgivelsen af dette bind betød et afgørende gennembrud. Til forskel fra den »virksomhedspsykologiske « retning, der også i tysk sociologi stiler mod »human relations«, har Popitz, Bahrdt, Jüres og Kesting frem for alt ikke glemt, at virksomheden »i første linie er en arbejdsplads «, og interesserer sig i overensstemmelse hermed mindre for de såkaldt »mellemmenneskelige « eller »uformelle« forhold i industriforetagenderne og mere for de »formelle« forhold, »som har deres umiddelbare udgangspunkt i udførelsen af arbejdet «. Men idet de betragtede den konkrete arbejdsgang, stødte de ganske selvfølgeligt på kooperations-fænomenet, som følgelig blev centrum for deres unders $\varnothing$ gelser. Dette ualmindelig frugtbare udgangspunkt foranledigede Hans Paul Bahrdt til at behandle emnet yderligere $\mathrm{i}$ adskillige publikationer, $\mathrm{i}$ hvilke han specielt behandlede den moderne industrielle kooperations virkninger på virksomhedsorganisationen og påviste, hvorledes kooperative arbejdsstrukturer i stadig stigende omfang, intensitet og betydning inden for moderne industri »kommer i konflikt« med en hierarkisk virksomhedsorganisation, der har overlevet sig selv. Han viste, hvorledes kooperationen delvis har overflødiggjort de hierarkiske forbindelseslinier eller i de mindste gjort dem mere abstrakte og dermed har en tendens til en afhierarkisering, som stiller hierarkiet over for en »tilpasningskrise « (Industrieburokratie«, »Die Krise der Hierarchie im Wandel der Kooperationsformen« i: »Soziologie und moderne Gesellschaft; Verhandlungen des vierzehnten Deutschen »Soziologentages «; Enke-Verlag, Stuttgart, 1958 og 1959). Det kan være nyttigt som afslutning, at antyde nogle af de konklusioner, som Bahrdt og hans kolleger er nået frem til gennem deres empiriske forskning. 
Forfatterne til »Technik und Industriarbeit« nærmer sig begrebet kooperation, idet de høfligt men bestemt trækker en grænse mellem deres bestræbelser og de arbejds- og arbejdspladsbeskrivelser »som foretages i praksis«, der tilsyneladende har samme målsætning. Disse beskrivelser plejer at »isolere de enkelte funktioner«. Skønt en sådan isolering i visse tilfælde kan være uundgåelig, ja endog berettiget f.eks. ved lønberegninger, så er det dog på den anden side »ikke til at overse«, at industriarbejdet »på denne måde mister et vigtigt kendetegn «, nemlig det kendetagn, at det faktisk »ikke foregår isoleret, men inden for rammen af en større arbejdssammenhæng « og derfor - i en eller anden forstand - er samarbejde: »Det den enkelte arbejder har at gøre, og det han gør, får først mening i sammenhæng med de andre funktioner, af hvilke hans arbejde er afhængigt og samtidig er en del af«, hele hans arbejde er altså »anlagt på kooperation med andre arbejder « (T.u.I., S. 38 og 41). At det industrielle arbejde har dette kendetegn er ikke noget tilfældigt, overfladisk og forbigående, det er netop et af dets historiske kendetegn.

Det er erkendt, at en højt udviklet på gensidig afhængighed beroende kooperation forudsætter en højt udviklet rationel arbejdsdeling. Men en sådan arbejdsdeling muliggjordes først af »storindustrien«, som var baseret på »maskinmæssig produktion«, først her bliver »den samlede produktion, objektivt betragtet for sig, analyseret i sine enkeltprocesser, og problemet om hver enkelt proces' udførelse løst ved teknisk anvendelse af mekanik, kemi osv.« Forfatterne til »Technik und Industrie«, henviser udtrykkelig til Marx: »Med den største klarhed er det af Marx blevet erkendt og forklaret «, at »kooperationen ikke blot har en systematisk arbejdsdeling som forudsætning, men også produktionens teknificering (T.u.I., S. 70). Med den fremadskridende mekanisering, siger Marx, fjernedes den tilfældighed og subjektivitet, der havde præget kooperationen i manufakturperioden. »Maskindriftens udviklede stade « »maskinerisystemet «, som »en kombination af delarbejdsmaskiner «, »en kæde af forskelligartede men hinanden kompletterende værktøjsmaskiner«, »som i forbindelse med et transmissionssystem sættes i bevægelse af en central automat der i sin helhed selv udgør »en stor automat «, som arbejderen forefinder som færdig materiel produktionsbetingelse« dette system »kan kun fungere under samfundsmæssigt eller fælles arbejde. Selve arbejdsprocessens kooperative karakter bliver nu en teknisk nødvendighed direkteret af selve produktionsmidlet«. Forfatterne af »Technik und Industriarbeit« fortsætter: »Marx redegørelse gør det klart, hvad vi mener med kooperation. Kooperation er ... samarbejde i det tekniske industriarbejde. For kun udfra arbejdets tekniske betingethed er det muligt at forklare arbejdsudførelsen som sådan som et socialt fænomen«. (T.u.I., s. 71 f).

Arbejdets tekniske betingethed, dennes konkrete form og grad, er udslagsgivende for den form, den konkrete kooperation har. Det viser historien. Efterhånden som den industrielle produktionsteknik fra en primitivbegyndelse blev gjort mere og mere fuldkommen og dermed i endnu højere grad gjorde 
teknikken til en forudsætning, i samme grad udfoldedes og intensiveredes kooperationen. Det tekniske fremskridt var udviklingens drivkraft, kooperationen udviklede sig som følge af en aktiv tilpasning fra arbejderens side til det præstationskrav det tekniske arbejde stiller. Eller ifølge de Toynbeeske formler, der citeres i T.u.I.: Udviklingen af kooperationen var arbejderens »svar « på de tekniske fremskridts »udfordring « (T.u.I. S. 175). Men kooperationen følger ikke kun historisk og i almindelighed produktionsteknikkens niveau. Det er langt snarere sådan - delvis netop som følge af den karakteristiske planløshed og mangel på samtidighed, der må siges i hvert fald under de kapitalistiske betingelser at kendetegne produktionsteknikkens udvikling, at der også i de mest moderne industrivirksomheder, arbejdes med maskiner på et indbyrdes ganske forskelligt niveau. M.h.t. kooperationen sker der derfor det, »at de forskellige tekniske anlæg kommer til at spille en differentierende rolle«. Derfor består »vores første opgave« $\mathrm{i}$ at »definere begrebet kooperation i det enkelte tilfælde og finde frem til de forskellige former for kooperation« (T.u.I. S. 45).

To grundformer for kooperation kan man »adskille og sætte over for hinanden «, selvom »man dermed ikke har fået alle former for kooperation med «: »teamagtig « og »struktureret « kooperation.

Den »teamagtige « kooperation nærmer sig mest det billede af den »klassiske«, »hånd-i-hånd « arbejdende »arbejdsgruppe«, som mange industrisociologer ikke kan løsrive sig fra. Den bliver anskueliggjort af P., B., J og K. ved eksempel på kooperation mellem nogle malmkørere. Seks malmkørere arbejdede i malmblanderiet i et højovnsanlæg, - og der må det bemærkes, at det drejede sig om et teknisk set forældet anlæg, et håndblanderi.

Hver enkelt af de seks skal køre en bestemt slags malm eller tilblanding fra malmbunkerne til vægten, hvorfra det køres op til højovnsoptrækket. Men deres »fælles arbejdsopgave« er først til ende, når alle har bragt den samlede mængde, der udgør en ladning malm til veje. Dette må ske inden for et ganske bestemt tidsrum, hvis rammer er afstukket af »det tekniske anlægs egentid «, nemlig den tid optrækket bruger til at tilbagelægge vejen nedefra og op og oppefra og ned. Men inden for denne fællesopgave er der for den enkelte malmkører en »vis mulighed for at disponere «. Han kan inden for visse grænser selv bestemme, fra hvilket felt han vil hente sin malm, han har en vis frihed til at opdele sin tid, han kan oparbejde et forråd for at få en større samlet pause. Denne frihed giver også malmkørerne »mulighed for at hjælpe og understøtte hinanden «, en mulighed der i bestemte situationer bliver til en forpligtelse. »Kollegialiteten har i forbindelse med denne type kooperation et stort spillerum. Den er til en vis grad fremtvunget [...] For så vidt frembyder denne måde at kooperere på mulighed for mange former for informelle gruppedannelser«. (T.u.I., s. 47-52).

Et helt andet ansigt viser den »strukturerede « kooperation som Popitz, Bahrdt, Jüres og Kesting udførligt beskriver den med eksemplet om »kørsel« i en blok- 
linie. Ved denne bloklinies kontakt- og styresystem koopererer tre arbejdere: kantvognsfører, styrmand og valsetræksmekaniker. »Udvalsningen af blokken er i alle sine faser et resultat af subtile og præcise i hinanden indgribende, forskelligartede arbejdsprocesser udført af forskellige folk «. Under udførelsen bliver denne gensidige indgribens art og måde, »formidlet af det tekniske anlæg «. Kooperationen sker altså »på vejen gennem det tekniske anlæg «, der »pålægger arbejdet en streng tidsmæssig orden« bestemt af »dett tekniske anlægs egen tid, den rækkefølge hvorefter udførelsen finder sted og nødvendigheden af at beskytte processens kontinuitet «. Hver eneste mand i bloklinien har en »specialiseret, skarpt afgrænset arbejdsfunktion «, hver eneste mand er bundet til en »fast arbejdsplads«. Medens de under udøvelsen af deres funktion på den mest direkte måde er henvist til hinanden, kan de ikke direkte hjælpe hinanden »ved umiddelbar medvirken i en andens arbejdsområde«. Derimod kan de hjælpe hinanden indirekte. I tilfælde af en fejl, der sniger sig ind hos den ene, kan den anden »enten ved af reagere i rette tid undgå at fejlen kører videre og improvisere en variation eller ved at udføre sin egen arbejdsdel bedre, mere præcist og hurtigere«. Da fejl, ofte af stort omfang, hyppigt truer de anlæg, hvor den »strukturerede « kooperation er fremherskende, understreges det sociale indhold i den »strukturerede« kooperation af alle de »krav om at undgå fejl«, der rettes til alle »struktureret« koopererende (T.u.I. s. 54-56).

For $\varnothing v$ rigt er »struktureret« kooperation også ganske almindeligt forekommende i den ikke-industrielle hverdag. Man kan f.eks. tænke på to biler, der mødes på en besværlig vejstrækning en nat med silende regn. Der opstår ofte »tilspidsede situationer, som kun kan klares ved hjælp af begge parters behændighed «. En fejl begået af en af de kørende »kan trække begge kørende ind i en fælles ulykke«. Også her er »ulykkesrisikoen ved en sådan fejl... langt større end i de fleste handlinger, hvor der ikke er en maskine med i spillet«. Også her kan en fører kun udligne en fejl begået af den anden »ved at variere sin egen kørsel«, heller ikke her kan han »umiddelbart hjælpe den anden«. Og heller ikke her »er de to kørende umiddelbart nærværende men kun ved den måde deres maskiner reagerer på. Deres samarbejde formidles af maskinerne«. Vore to kørende »koopererer « altså på en vis måde »struktureret « selvom »deres kooperation « i modsætning til den industrielle kun varer nogle få sekunder (T.u.I. S. 185 f).

Popitz, Bahrdt, Jüres og Kesting »lægger... særligt eftertryk på det strukturerede samarbejde« (T.u.I. s. 47). Det gør de af flere grunde. Overfor den »teamagtige « udgør den »strukturerede « kooperation den mest fremskredne kooperationstype. »Medens den teamagtige kooperation finder sted ved relativt ukomplicerede tekniske anlæg er det strukturerede samarbejde tilegnet de komplicerede og moderne tekniske apparaturer som valseveje, udligningsovne, koksbatterier o.s.v. Derfor er den også i større udstrækning teknisk bestemt end den teamagtige kooperation «. (T.u.I. s. 55). Endelig kan man iagttage en tendens i den moderne industri »til at den teamagtige kooperation afløses af den 
strukturerede « (T.u.I. s. 209). Men desuden er den »strukturerede« kooperation også model for de større kooperationssammenhæng i industrivirksomheden, som i T.u.I. er blevet døbt »arbejdsstruktur«.

Ved disse arbejdsstrukturer drejer det sig »ikke... om arbejdsgrupper af en højere orden, de er ikke kun sekundære fænomener men også primære...« Der tilkommer dem altid »en ganske særlig betydning «, på samme måde som »i et kombineret jernværk «, hvor produktionsprocessen falder i »enkelte arbejdsgange som klart adskiller sig fra hinanden«. Netop disse »enkelte arbejdsgange, der klart adskiller sig fra hinanden « udgør som »kooperationsenheder « de nævnte »arbejdsstrukturer «. I en sådan »arbejdsstruktur « arbejder f.eks. de ovennævnte seks malmkørere sammen med to kokskørere, to vejere og to lastefolk, en elevatormaskinist og fire giktfolk ved chargeringen af den nævnte forældede højovn. Der er andre »arbejdsstrukturer« i gang ved konvertanlægget, de enkelte koksbatterier og de enkelte valseveje. Hver »arbejdsstruktur « er en »kooperationsenhed med en fælles arbejdsopgave... ved et teknisk anlæg «, hvor »arbejdsstrukturens enhed dannes som følge af det tekniske anlægs enhed «. Den fælles arbejdsopgave påhviler enten »flere enkelte arbejdskræfter « eller »arbejdskraftgrupper «, som hver for sig koopererer teamagtigt. Men kooperationen mellem enkelte arbejdskræfter og arbejdskraftgrupper $»$ viser... alle det strukturerede samarbejdes kendetegn «. Det betyder punkt for punkt: 1) »den kooperation der udgør arbejdsstrukturen, bliver formidlet af et teknisk anlæg « 2) Desuden består der en fast systematik i arbejdsområderne, og »arbejdskræfterne er i stort omfang fikseret ved disse arbejdsområder «3) »desuden er en streng opdeling af arbejdsfunktionerne forbundet med arbejdsområdernes faste systematik... Anlægget dikterer arbejdsfunktionernes gensidige afhængighed «. 4) »arbejdet og samarbejdet er undergivet en tidsmæssig orden, som til mindste detalje er bestemt af det tekniske anlæg«. 5) »er det kun muligt for arbejder at give en anden en håndsrækning, når han umiddelbart deltager i udførelsen af et arbejde, hvor teamagtige grupperinger er koblet ind i en struktureret sammenhæng 6) Derimod er det muligt for den ene ved hjælp af improviserede kvalitative ændringer $i$ arbejdsgangen at rette op på fejl og fjerne usikkerhed hos den anden« (T.u. I. s. 72-84).

»Af det tekniske anlæg afhænger det... om der igen inden for arbejdsstrukturen kan befinde sig enkelte grupper, som koopererer teamagtigt, eller om den samlede arbejdsstruktur er dannet af enkelte kun struktureret koopererende arbejdskræfter«. Om man vil, kan man tale om »arbejdsgruppestrukturer « eller »arbejdskraftstrukturer « (T.u.I. s. 209). »Set ud fra produktionsprocessen« kan man også udtrykke det således: Produktionsprocessens mekanisering isolerer undertiden enkelte arbejdsfunktioner, som må udføres af menneskelig arbejdskraft. Disse arbejdsfunktioner udføres enten af en enkelt arbejdskraft (»Struktureret« kooperation) eller den overtages af en gruppe arbejdskræfter (»teamagtig « kooperation). Men her må det understreges: »Den stigende mekanisering 
fører til udelukkelse af de teamagtige faktorer inden for arbejdsstrukturen«. Som eksempel tages et videreudviklet chargeringsanlæg. Videreudviklingen »opløste de teamagtige koopererende arbejdsgrupper og skabte en arbejdsstruktur, som ikke mere fremviste nogen gruppestruktur (T..I. s. 84-91, 209).

I ekstreme tilfælde kan »arbejdstrukturen« strække sig gennem flere afdelinger. Bahrdt skildrer i »Industriebürokratie« en »målepladsleder«, en lille funktionær, som i et kombineret bjergværk registrerer de ved højovnsprocessen tiloversblevne giftgas, fordeler den til aftagerne i virksomheden, og - hvis han ikke komme af med det - brænder overskuddet. »Man forlanger af ham, at han på et specielt område skal optræde som koordinator mellem jernværkets enkelte virksomheder, der hver for sig er lige så store som storforetagender «.

Lignende udvidede arbejdsstrukturer kender Bahrdt fra koksværker, automobilindustrien, rangerbanegårde, kraftstationer og fra den tekniske industri, »hvor hele kæder af kæmpemaskiner « på størrelse med en mellemstor fabrik, betjent af ganske få arbejdere, må arbejde i samme takt, og hvor der må reageres $\varnothing j$ jeblikkeligt og samtidigt, når uregelmæssigheder dukker op «. Allerede »målepladslederen«s arbejdssted var et samlingspunkt for helt store »værkkomplekser «. De nævnte stærkt automatiserede kæmpemaskinerier giver en indtykket af, at flertallet af sådanne arbejdspladser befinder sig ved sådanne samlingspunkter, ja, at der i den automatiserede produktion kun befinder sig mennesker der, hvor de selvstændigt arbejdende anlæg skal koordineres og afstemmes efter hinanden« (D.s. 37 og 39). Når man betragter de omfattende, stormaskede kooperationsstrukturer i de teknisk mest udviklede virksomheder, særligt de kemiske, »i hvilke i fremtidens automation allerede var begyndt før man stort set talte om automation « øjner man perspektiverne i udviklingen. »Er der så egentlig mening i at tale om produktionsarbejdere? Er en mand, der i hovedsagen formidler, koordinerer, kontrollerer og nu og da regulerer, hvor anlægget ikke kan regulere sig selv, et menneske der producerer? I hvilken henseende adskiller hans aktivitet sig egentlig fra hans foresattes...? « Der er en forskel, der måske er ganske tungtvejende: »En sådan arbejder skal helt sikkert kun kommandere over maskiner, ikke mennesker «. Men denne kommandoreduktion er under alle omstændigheder et tidens tegn »thi hvornår kommer hans umiddelbart foresatte overhovedet nu til at kommandere « (D.s.s. 33 og 39). Således udmunder forandringen i en »hierarkiets krise« (k.d.H.s. 119).

Denne krise kommer frem for alt til udtryk som »den umiddelbart foresattes funktionstab « (T.u.I. s. 212). Denne kendsgerning er ikke forblevet skjult for de implicerede og mange udenforstående, »men man overser i almindelighed, at den tekniske udvikling måtte føre til funktionsforskydelse, som ikke kan forandres «. (Ds. s. 29).

Det er til syvende og sidst de af den tekniske udvikling betingede og deraf følgende moderne kooperationsformer, som på en progressiv måde har undergravet den nederste del af hierarkiet og har gjort dens eksistens problematisk. 
Og det ikke kun i én henseende. Man behøver blot at tage fundamentet, hvorpå virksomhedshierarkiet hvilede, disciplinærmagten. Denne magt udøver det omend med store indskrænkninger - også i dag. Alligevel er der sket noget afgørende. Som bekendt var det $\mathrm{i}$ industrialiseringens første stadier en ligeså vanskelig som nødvendig opgave at tilpasse en »stadig fluktuerende, legemlig overanstrengt, dårlig betalt og dårlig uddannet arbejdskraft« (Ds. s. 35) til den industrielle produktionsproces' betingelser. I den forbindelse var det nødvendigt at vænne arbejderne til et mindstemål af disciplin. Med denne opgave voksede og skoledes hierarkiet. Ganske vist anvendte det til at begynde med kun ganske yderlige og grovkornede metoder. »Det passede kun på, at der arbejdedes hurtigst muligt, uafbrudt og påpasseligt... »Det befalede ikke, hvorledes der skulle arbejdes, men kontrollerede produkternes kvantitet og kvalitet og forhindrede, at der i arbejdstiden lavedes andet end arbejde (K.d.H.s. 117). Med andre ord, det indskrænkede sig til at føre opsigt - og, naturligvis, strafferegistret.

En sådan disciplineringsmetode var ubrugelig, ja, direkte skadelig i det omfang industriarbejdet blev mere teknisk betinget og teknisk rationaliseret og dermed i sig selv virkede stadigt mere disciplinerende. Dets disciplinerende kraft når sit højdepunkt i »den strukturerede kooperations præstationskrav«. I den »strukturerede« kooperation kan arbejderen kun betjene det tekniske anlæg efter hensigten, hvis han udfører hver eneste funktion i overensstemmelse med den nødvendige kooperation med andre. På den anden side virker denne kooperation først, når enhver arbejdsoperation på et hvilket som helst trin af arbejdet udføres i overensstemmelse med det givne tekniske anlæg. Da »manglen på tekniske færdigheder, svigten over for maskinens krav... er farlig for fællesskabet i den strukturerede kooperation «, bliver »den enkeltes tekniske færdighed... til en social forpligtelse «. »Den sociale forpligtelse i forbindelse med den enkeltes handlemåde er den disciplinering, som maskinen kræver (T.u.I. s. 164-90, 213). Denne disciplinering som maskinen kræver er til forskel fra den af hierarkiet gennemførelse rent sagligt begrundet. Den har sit udspring i »det tekniske anlægs ratio«, som »efterhånden er blevet mere entydig, indlysende og begribelig for den enkelte arbejder«; det vil ikke falde nogen arbejder ind »at handle mod den indlysende lovmæssighed«, som maskinen eller apparatet er i besiddelse af (T.u.I.s. 211).

»Han underordner sig hellere dens logik og direkte forståelighed end menneskenes vilkårlighed «. Endelig kan produktionsprocessen undvære menneskenes vilkårlighed. Følgerne af en omstrukturering bliver, at de hierakiske strukturer blegner bort og bliver uvigtige, og under denne omstrukturering skaber de tekniske funktionssammenhænge nye kooperationssammenhænge nye kooperationsformer, og den ligger nærmere ved en integrationsmåde, der passer bedre til arbejdernes mentalitet end indordningen under et stramt, konstant fungerende og ydmygende hierarkisk system, hvori de kun kan indtage det nederste trin.

I samme retning peger også den »enkelte arbejders tiltagende egetansvar « (T.u.I. s. 211 f). Også det skyldes de nye, tekniske betingelser for det moderne 
industriarbejde. Arbejderen må »i den supertekniske virksomhed i større udstrækning handle på eget ansvar« (Ib. s. 29). Det er typisk for arbejdsprocesserne inden for rammerne af »strukturerede« kooperation, at den hele tiden skaber situationer, der kræver en afgørelse. Denne afgørelse må den enkelte arbejder selv træffe. F.eks. styrmanden ved blokvalsen må på egen hånd afgøre, om han skal »acceptere eller tilbagesende « en blok, der er utilstrækkeligt opvarmet. »Der er ikke op til hans forgodtbefindende, om han skal træffe valget eller ikke, det melder sig automatisk... Således er hans beslutning i sagen på forhånd givet, nemlig i blokkens tilstand... Blokkens tilstand berettiger enten til at han accepterer den eller den umuliggør det. Konsekvenserne er tilsvarende. Hvis styrmanden tager fejl, så kan valsen under visse omstændigheder brække, hvilket betyder en enorm skade; og det er givet at der p.g.a. fejltagelsen går tid tabt, og der opstår ofte skrot for slet ikke at tale om vanskeliggørelse af arbejdet « (T.u.I? s. 62-63). Beherskelsen af de ofte kæmpestore maskinerier, rådigheden over mægtige tekniske kræfter, regulering af de som oftest automatisk fungerende processer kræver af den enkelte arbejder ikke kun permanent anspændt koncentration, men også erfaring og hin særlige evne, som P., B., J og K kalder »teknisk sensibilitet « (T.u.I. s. 191-198) en slags fingerspidsfornemmelse, evnen til en saglig dom og en spontan reaktion. Det måske tydeligste udtryk finder denne arbejdernes nye selvstændighed og egenansvarlighed i visse kemiske storvirksomheder. I »hele grupper af tekniske afdelinger placeret langt fra hinanden « arbejder ofte "per skift kun ganske få arbejdere, af og til kun én eller to«. De må sommetider »ganske alene udføre meget ansvarsfulde funktioner ved deres armaturer «. Således er de »i det store og hele henvist til sig selv«. Her er så den enkelte arbejder »ikke længere uden videre udskiftelig. Han er et individ, som man om muligt behandler individuelt, for man er tvunget til at stole på, at han på sin ensomme arbejdspost af sig selv gør, hvad man venter af ham.«

$»$ Disciplinen, ansvarsfølelse, kontinuiteten i arbejdsydelsen, villigheden til selvstændig kooperation «, som den moderne supertekniske produktionsproces kræver af arbejderen, og som denne præsterer - udgør så at sige den positive basis for krisen i det lavere hierarki, den såkaldte »værkførerkrise «. Dennes kerne består i at de funktioner, hvori værkføreren var tydeligt synlig som overordnet, er faldet helt bort eller trådt i baggrunden. »Vi kan mange steder iagttage, hvorledes værkføreren ligefrem bliver trængt bort fra den normale arbejdsproces, hvori han tidligere medvirkede aktivt, idet han nemlig disponerede, befalede, kontrollerede og korrigerede. Der eksisterer næppe længere noget spillerum for »anvisninger «. Hvad der skal gøres, ved arbejderen selv, det fremgår af de tekniske anlægs lovmæssigheder. Hvordan han skal gøre det, kontrolleres enten af automatiske skriveindretninger, eller behøves slet ikke at blive kontrolleret, thi en hvilken som helst fejl ville føre til en for alle sigtbar forstyrrelse. Der er kun ringe anledning til formaning og belæring - undtagen i oplæringstiden. Ofte ved arbejderen bedre besked med sit specielle arbejdsområde end værk- 
føreren..« Denne trækker sig enten tilbage til sin byrokratiske funktion eller affinder sig med tingene og gør sig nyttig andetsteds, først og fremmest ved arbejdsforberedelsen eller ved reparationsarbejder; men disse opgaver »fremstiller ham sjældent som befalende eller opsynsmand «. Det er tydeligt at også andre muligheder vinker. »I et meget moderne koksanlæg var den vane opstået, at værkføreren regelmæssigt hentede kaffe til sine underordnede, for de var i den grad bundet til deres spredte ensomme pladser, at de ikke kunne forlade dem. Altså var kun den overordnede nu og da undværlig «. (Ib. 31-34, 39).

»Værkførerkrisen «, det lavere hierarkis krise kan kun ses som et »symptom « på en generel udvikling. Overalt, på alle planer krydser og skærer de hierakiske forbindelslinier de kooperative. De store kooperationsstrukturer »ligger undertiden på tværs af den traditionelle hierakiske virksomhedsorganisationer og kan derfor geråde i konflikt med den. På langt sigt opstår der ikke som følge heraf en desintegration, men højst en tilpasningskrise, som praksis dog idag i mange tilfælde - skønt endnu ikke formelt - plejer at kunne klare« (Ib.s. 34 og 36). Fordi »praksis« nemlig i »realiteten« ellers ikke ville kunne fungere. Om konflikten når at komme til udbrud, om krisen aktualiseres afhænger faktisk i høj grad af den måde, hierakiet selv forholder sig på. Spørgsmålet er »hvor store« dets »prætentioner « er om i »enkeltheder at gribe ind i arbejdets udførelse « K.d.H.s. 116). Hvis hierakiet er fristet til hele tiden at gøre sig gældende som hieraki, kan »friktioner «, »uendelige kompetencestridigheder, som udløser en bølge af byrokratisk hårkløveri« ikke undgås. Omvendt kan man meget vel tænke sig en relativ krisefri »tilpasning « $\mathrm{i}$ de tilfælde, hvor hierakiet undlader at blande sig i »arbejdets udformning « og kun i ringe grad optræder som hierakie eller helt går ind i kooperationen. »Man kunne næsten sige: jo bedre hierakiet fungerer, desto mere indirekte er det« (Ib. s. 35). Det betyder vel også desto mindre synligt. Hvis hierakiet ikke vil kæmpe til sidste mand på deres poster med opslidende rivninger og uenigheder, ærgrelse, til sidst fulgt af produktionstilbagegang, så må de »i det lange løb « vige for udviklingstendenserne. Men denne udvikling, der tenderer mod at ophæve den gamle hierakiske, vertikalt leddelte orden i virksomhederne, danner samtidig de »nye ordenselementer « (Ib. s. 36), der er i stand til at erstatte den gamle - den horisontalt leddelte organiserede kooperationsstruktur, der ikke længere kan deles i »oppe « og »nede«, ikke mere organiseres som »menneskers hersken over mennesker«.

Hvis ikke man tager helt fejl, ser det ud til at kooperationen endog betyder mere, end man uden videre skulle tro, når man betragter dens sagligt-beskedne rolle i industrisociologien4 Grundelementerne ikke kun til en ny virksomhedsorden, men også til en samfundsorden, en samfundsorden, hvis konturer længe har været synlige, og som nu blot kommer på en anden måde, end den man altid har tænkt sig. 


\section{Solidarisering som historisk mulighed*}

\section{Michael Vester}

Den nyere uro blandt arbejderne og den studerende ungdom, som er fulgt efter perioden med relativ apati, har udløst en åndrig diskussion om spørgsmålet: Er den nuværende situation i kapitalismen revolutionær eller ej?

Fremtidsperspektiver for systemforandrende praxis i den nyere kapitalisme Spørgsmålet synes at være forkert stillet. Det forudsætter, at »revolutionær« er en tilstand eller en tingslig egenskab. Det konstruerer først en idealtypisk revolutionær. Denne lægger det så udefra som målestok over det betragtede objekt. Spørgsmålet kan derpå besvares med ja eller nej. således går f.eks. Jürgen Habermas til værks. Han tager idealtypen fra den manifeste klassekamp og fra den uløselige økonomiske krise i det 19. årh.: han sammenligner den med sit billede af dagens kapitalisme og slutter, at disse to betingelser for en revolution, »tror jeg, ikke længere er opfyldt i den statsligt regulerede kapitalisme.« (Bedingungen für eine Revolutionierung spätkapitalistischer Gesellschaftssysteme, i: Praxis, Heft $1 / 2$ 1969, p. 212). På samme måde bærer mange småborgerlige agitatorer sig ad. De holder deres billede på revolutionær adfærd op

* Oversat fra Heidelberger Blätter 14/16 1969-70, side 320-45. 
foran arbejderne; hvis arbejderne ikke følger dette billede, bliver det tydet som udtryk for en kontrarevolutionær bevidsthed.

I begge tilfælde fører det negative svar ikke til en prøvelse af deres egne idealtyper. Professoren spørger ikke, om klassekamp og krise i det 20. årh. kunne have en specifik anden form end i det 19. årh. Agitatoren spørger ikke, om den reformistiske selvvirksomhed (f. eks. i spontane strejker) kunne være et nødvendigt skridt i en i sit udfald revolutionær læreproces. Og han spørger heller ikke, om arbejderne måske har mistillid til ham, fordi de i hans opførsel mærker et lederskabskrav. Den erkendelsesdirigerede interesse hos professoren som hos agitatoren er her åbenbart mindre rettet mod det proklamerede tema end mod den skinsyge bevarelse af egen socialstatus. Professoren vil gendrive Marx og sine egne kritikere. Agitatoren vil bekræfte sig selv ved, at ingen er så »revolutionær« som han selv.

Af dette narcissistiske lederskabskrav følger en rent fortolkende holdning, der udefra afsiger endegyldige domme, og som ikke trænger ind i objektets indre modsigelser: (Thi kun endegyldige domme kan bruges som statusviden). Udfra denne position kan modsigelsesfulde forhold, som kan influeres i forskellig retning gennem indgribende handlen og tænkning, ikke begribes. Historisk dynamik, kan, forekommer det mig, overhovedet kun iagttages i en kommunikerende proces, der fatter og forandrer det erkendende og erkendte. Men den, der er steget fra fortolkningens kateder ned i forandringens vrimmel, kan ikke længer skelne rigtigt og forkert, men kun muligt og uvist. Overvindelsen af den statisk-fortolkende tilnærmelse kan altså heller ikke ligge i forkyndelsen af optimistiske visheder: ikke i, at alt, hvad der endnu eller igen bevæger sig, bliver erklæret for revolutionært.

Forudsigelser om historiske muligheder havde hidtil deres tyngdepunkt $\mathrm{i}$ analysen af de såkaldte »objektive processer«. Menneskenes handlinger lader sig imidlertid ikke forklare alene udfra systemets virkninger, frem for alt de $\varnothing$ konomiske institutioners. Om disse virkninger føles som degraderende og som anledning til modhandlinger, var omkring 1850 ikke et problem. I de arbejdende klasser var individuel autonomi og social solidaritet endnu livets målestokke for, hvordan det skulle være. Siden da har disse kulturelle værdimønstre mistet meget af deres evidens. Men når de må genoprettes, som forudsætning for revolutionær handlen, så må de gøres til genstand for direkte analyse og direkte praxis. Til unders $\emptyset$ gelsen af et klasseforhold i udvikling anser jeg en sociologisk ansats for fornuftig, som fastholder betydningskriterierne for sociokulturelle værdimønstre. Disse er målestokkene, efter hvilke menneskene tyder og udlægger samfundsmæssige data og finder en konsensus over koordinationen af deres handlinger og reguleringen af konflikter. Min interesse retter sig dermed særlig mod de førpolitiske områder. Hvorvidt er der heri indeholdt værdiforestillinger om autonomi, solidaritet, livsnydelse o.s.v.? Hvorledes skal disse forestillinger oplives? Hvorledes skal de udvides fra den private morals område, som de blev trængt tilbage i, til den politiske morals område? Meningen med en revolution er vel intet andet end sikringen af de almene institutionelle forudsætninger for en 
sådan ny menneskelig adfærds kultur. Men denne kultur må i forvejen i en lang proces udvikles i det antisolidariske samfunds skød.

Edward Thomson skrev i 1960 i samlingsbindet »out of apathy « - det Nye Venstres grundlæggelsesdokument: »På en vis måde lever vi i dag bestandig på tærsklen til en revolutionær situation. Det beror på, at vi ikke vover at gennembryde de traditionelle konventioner mellem os og den situation, hvis apatien, åbenbaret som politisk forfald, endnu i dag er fremherskende«. Det implicerer tesen om, at den såkaldte »objektive modning « til befrielse for mangel og angst allerede var nået $\mathrm{i}$ industrilandene, at løsningen på problemerne i stigende grad skulle søges i motivationen til engagement og participation, den sociale fantasi, forandringen af den individuelle psyke og den sociale kommunikation. Thomson, Williams og deres fæller signalerede, i tilslutning til den første arbejderbevægelses kulturrevolutionære motivation, en for den europæiske situation adækvat kulturrevolution: konkurrencens og lydighedens vante skik og brug ville blive afløst af solidaritet og autonomi. Gennembrydningen af de kapitalistiske »konventioner «, af antifantasien, er dermed postuleret som indholdet i det overgangsprogram, der skal føre fra det nuværende til det fremtidige samfund.

En sådan overbevisende overgangsteori mangler i dag. Utopi og realitet stilles uformidlet over for hinanden. Med overgangsteorien mangler tillige individernes evne til rationelt at forudberegne en antikapitalistisk praxis' virkninger og at begribe enkelthandlingers betydning for den samlede historiske proces. Forestillingen om et tidsperspektiv er en vigtig forudsætning for en kontinuerlig kampmoral, som ikke lader sig irritere af enkelte frustationsoplevelser. Dertil hører ganske vist også indsigten i, at en fast plan over stationer og mål på denne vej ikke kan udarbejdes og heller ikke må fastlægges hen over hovederne på den sig emanciperende klasse. Og dog er det muligt og fornuftigt tydeligere end hidtil at klargøre sig klassekampens sandsynlige betingelser, udsigter, situationer o.s.v. i en besemt historisk periode, såvel som en sådan udviklings forskellige tænkelige varianter. Således ville det blive muligt, at den antikapitalistiske praxis ikke længere reagerende, men initierende, ikke længere halvblindt, men bevidst, ikke længere fikseret omkring isolerede aspekter af repressionen, men omfattende griber ind i den historieskabende proces.

De følgende overvejelser skal kun forstås som et foreløbig bidrag, der i diskussionen endnu må korrigeres og suppleres.

\section{Politisk og social revolution}

Fra det 19. årh. er der overleveret to modeller for den politiske revolution: en gradualistisk og en katastrofisk. Begge havde engang en revolutionær betydning. I dag betegner de forandringer, der udgår fra bureaukratiske organisationscentre og ikke fra folkemassernes direkte aktion. (Da det for mig ikke drejer sig om idehistoriske efterforskninger, bruger jeg her udtrykkeligt de udbredte vulgæropfattelser af »reform« og »revolution« som udgangspunkt for kritikken). 
1. Det gradualistiske overgangsprogram vil forandre, »demokratisere«, de herskende institutioner gennem en mere eller mindre kontinuerlig rækkefølge af mindre reformskridt. I denne opfattelse af den så at sige umærkelige voksen over i socialismen er bl.a. følgende problematisk.

Subjektet i disse reformer, lovgiveren, kan kun kontrolleres meget middelbart af befolkninen (vælgerne, partimedlemmerne), mens statsbureaukrati og priviligerede samfundsgrupper (frem for alt kapitalistiske) relativt direkte kan $\emptyset \mathrm{ve}$ indflydelse på hans beslutninger.

Indholdet i disse reformer er tilsvarende kun sjældent en demokratiserende magtomfordeling. Disse reformer forbedrer ganske vist hyppigt de underpriviligerede gruppers forskellige standards, men forøger kun sjældent deres aktive deltagelse, fordi deres institutioner er bureaukratisk-hierarkisk organiseret (sml. medbestemmelse).

Tidsperspektivet i disse reformer er illusorisk. Lovgiverens beslutninger reflekterer, inden for visse spillerum, magtforskydninger på førpolitiske samfundsområder. Når de arbejdende masser forholder sig relativt passivt-apatisk, bringer de kapitalistiske markedslove på produktions-, distributions-, forvaltnings-, kommunikations-, kulturområder o.s.v. den planlagte reformserie til standsning og får den til sidst til at løbe baglæns.

2. Det katastrofiske overgangsprogram vil fuldstændig ødelægge de herskende institutioner i et pludseligt og kortere eller længere afgørende slag for så at opbygge et for det meste ikke nærmere defineret system af kvalitativt fuldstændig nye institutioner. Ved det er det følgende problematisk.

Subjektet i en sådan omstyrtning er som regel blot en ny lovgiver, der selvstændiggør sig over for masserne, også hvis disse delvis har hjulpet ham med at komme til magten.

Indholdet i reformprogrammet er tilsvarende ikke en fuldstændig ny beslutningsstruktur, heller ikke skønt visse underpriviligeringer ophæves.

Tidsperspektivet i den pludselige fornyelse er illusorisk, forsåvidt det tilskriver omstyrtelsesakten for megen skabende kraft. En politisk revolutions korte fase kan ganske vist give institutionerne nye retssystemer. Forandringen af det sociale, økonomiske og kulturelle realsystem forudsætter menneskenes langvarige adfærdsændringer. Hvis disse ikke er tilstrækkeligt fremskredne før den politiske revolutions begyndelse, kan de uundgåelige modsigelser mellem befolkning og parti, ofte forbundet med udenlandske interventioner, føre til partiets politiske fald eller til dets bureaukratiske diktatur.

Såvel den gradualistiske som den katastrofiske opfattelse er etatistisk. Deres organisationsform er det hierarkisk organiserede politiske parti. Dette opfattes først kun som middel til (den fredelige eller voldsomme) erobring af statsmagten. Det skal fordrive den gamle klasse fra dens magtspositioner, selv besætte disse magtpositioner og (her begynder modsigelsen) ved hjælp af statsmagten 
afskaffe statsmagten. Derfor gjorde det bureaukratiske herredømme ikke af egen drift plads for den kooperative selvforvaltning. Kun modmagten fra en fællesbevægelse kunne gennemføre dette, hvis den allerede havde konsolideret sig før den politiske magtovertagelse. Tilnærmelser til en sådan ikke-etatistisk revolutionsopfattelse findes idag i den Tredje Verden. Men de bygger på en agrarisk struktur og førkapitalistiske kulturmønstre, som ikke er til stede i de overudviklede lande. For industrilande er snarere den revolutionær-syndikalistiske bevægelse, frem for alt Spaniens, af interesse.

Den spanske revolution blev grundigt fortrængt fra bevidstheden som alternativ model til den russiske. Den spanske fagforeningsbevægelse, i særdeleshed $\mathrm{CNT}^{2}$, forstod sig selv ikke blot som et middel til magtovertagelse, men tillige som organ for det fremtidige samfund. Utopien om en frihedskommunisme var bestandig præsent i organisationspricipperne for føderationen af autonome lokale foreninger, som i direkte aktioner og et omfattende oplysningsarbejde forberedte sig på det kooperative fællesvæsen, som om det allerede var muligt i morgen. Den årtier lange forberedelse, som trodsede voldsomme forfølgelser, realiseredes, da Francos statskup ødelagde statsmagtens instrumenter, politiet og hæren, og den reelle magt tilfaldt folkets organer. De syndikalistiske organer begyndte straks at fungere: mod den private ledelses vilje overtog de i udstrakte regioner bedrifterne, fødererede disse i national målestok og øgede straks udbyttet - også heri adskilte de sig fra Sovjetunionen. Af dogmatiske grunde afviste syndikalisterne imidlertid kontrollen med statsmagten, så at den republikansk-borgerlige regering, heri afgørende bestemt af de etatiske kommunister og afhængig af Sovjetunionen, kunne reducere den syndikalistiske magt. Den syndikalistiske fronter blev utilstrækkeligt bevæbnet og dermed var den $i$ begyndelsen vel mulige vending af krigen forspildt. Syndikalistiske forsøg på participation i politiske institutioner kom for sent.

Denne udgang på den spanske revolution modbeviser ikke, at de nye organisationsformer igennem mange år må udvikles i det gamle samfunds skød, hvis de efter en politisk omvæltning hurtigst muligt skal folde sig ud i fuldt flor. Den bekræfter kun, at netop den manglende deltagelse i den traditionelt organiserede politiske magtkamp kan begunstige venstrepartiernes selvstændigg ørelse.

3. Et passende overgangsperspektiv kan ikke udvindes af destillerkolben. Princippet om, at det nye samfunds former allerede før hele den politiske samfundsændring i praxis må udvikles i den samfundsmæssige basis, udsiger kun lidt om de konkrete nødvendigheder. Disse viser sig først i praxis.

Subjektet i revolutionære forandringer kan ikke være et bureaukratisk oligarki. Tværtimod er det nødvendigt, at de fremmedbestemte mennesker i deres daglige eksistenskamps basis, også uden for arbejdsprocessen, organiserer sig til parapolitisk selvvirksomhed. Principielt kan man kun forestille sig dette i

2. Confederacion Nacional del Trabajo, den anarkosyndikalistiske fagforening O.a. 
grupper af ligeberettigede og i egalitære føderationer af sådanne grupper, som foregribelse af en kooperativ samfundsstruktur. Det traditionelle parti- og fagforeningssystems faktiske organisationsmonopol komplicerer denne opgave. Konkurrenceorganisationer ville blive nødt til at tilpasse sig deres strukturer. En demokratisk basispraxis derimod ville problematisere disse strukturer og muligvis udløse forandringen.

Indholdet $\mathrm{i}$ en sådan praxis måtte primært være forandringen af magtog beslutningsstrukturer gennem direkte aktioner, d.v.s. gennem de berørtes egne handlinger og ikke blot deres repræsentanters. Afgørende er her tilegnelsen af autonome kontrolfærdigheder gennem den emanipatoriske klasse i læreprocesser, der er formidlet af praktiske konflikter. I disse processer må ikke blot strukturen mellem menneskene, men også deres indre psykiske struktur, som bestemmer deres adfærd, forandres af dem selv. Blandede beherskelsesorganer, i hvilke den emancipatoriske klasse kan blive majoriseret eller lammet, kan ikke vurderes til at være grundlag for sådanne transformationsprocesser. (Alligevel er monopolforbundenes organer ikke utvetydigt emancipationsfjendtlige. Medbestemmelse virker ganske vist beroligende, men formindsker også eksistensangsten som betingelse for apati. En levende producentgruppepraxis muliggjorde bedriftsråd, som ustraffet kan ignorere arbejdsgivernes og bedriftslovgivningens forlangender, og som aktivt fremmer udviklingen af medbestemmelse på arbejdspladsen eller spontane strejker.)

Tidsperspektivet måtte omfatte såvel graduelle som pludselige forandringer, isolerede daglige småkampe som større epidemiske oprør. (Denne problematik er genstand for de følgende afsnit).

\section{Nye kriseformer}

Forberedelsen på store forandringer kræver forudsigelser om, hvornår og hvordan et herskende system er så hjælpeløst, at indgribende handling og tænkning har chancer for at lykkes. Thi den sociale bevægelse har hidtil aldrig kunnet tvinge sin behersker i knæ af egen kraft - så at sige i et åbent feltslag. Den behøvede dertil en mægtig forbundsfælle: det herskende system selv, som frembragte problemer, det ikke kunne løse og som voksede det over hovedet. Hvornår et system er stabilt og hvornår det er ustabilt, om dets kriser er almene eller partikulære, om de maser sig på eller sniger sig frem, om de er manifeste eller latente lader sig ikke forudberegne med naturvidenskabelig nøjagtighed. For en fleksibel tilpasning af den sociale bevægelse til dens skiftende chancer er dette imidlertid heller ikke nødvendigt. Det er tilstrækkeligt at erfare de for en historisk periode karakteristisk mulige kampsituationer.

Det vigtigste hjælpemiddel til sådanne forudsigelser har hidtil været den på den marxske arbejdsværdilære funderede kriseteori. I sin indsnævrede og tingsliggjorte udgave har den i det 20. årh. haft en langt større betydning for venstreteoretikeres rivalitetskampe end for klassekampenes praxis. Når man 
holder fast ved »økonomiens« »objektive« udviklingslove glemmer man, at »økonomi« betegner den herskende klasses adfærd, som også kan forandre sig i grænserne gennem læreprocesser: en dynamisk kamprelation, og ikke en naturting, der kan løsgøres fra menneskelig handlen. Af denne indsnævring fulgte forsømmelsen af kulturelle og politiske processer. Massestrejke- og rådsbevægelserne eller ansatserne til dem er ikke kun opstået i den økonomiske konjunkturs med middelfrist tilbagevendende kriser, men også når herskende systemer var blevet rystet i deres grundvold i krige (som ganske vist var formidlet af $\varnothing$ konomiske herskerforhold). Og det kommer - som i Frankrig i 1968 - også til epidemiske oprørsbevægelser, når det økonomiske system formelt er stabilt. (At den formelle stabilitet selv er ideologi, undgår »moderne « kritikeres opmærksomhed, som Habermas, der - imod sin teoretiske tilnærmelse - erklærer arbejdsværditerien for uanvendelig, fordi han indsnævrer dens betydning).

\section{Forskydelsen af krisestendenserne}

Kapitalismens integrationsformel, som den havde udvundet af erfaringerne indtil den verdens $\varnothing$ konomiske krise, bestod i, gennem statslig intervention, at forvandle det 19. årh.s krisefænomener, katastrofale $\varnothing$ konomiske sammenbrud og industriarbejderbevægelser, til kontrollable størrelser. Den verdensøkonomiske krise 1929-1939 førte til den uafviselige indsigt, at de kapitalistiske markeder, på grund af deres, stive oligopolitiske struktur, ikke af egen kraft kan stabliliseres på et niveau med produktivkræfternes fulde beskæftigelse. Siden da har politiske og psykologiske stabiliseringsmetoder vundet stadig større betydning. Arbejdsgivernes aktivitet sættes atter og atter i sving gennem statslige lettelser. Disse indgåede skatter går til sektorer, som er til størst profit for arbejdsgiverne: hellere til oprustning end til offentlige ydelser. Samtidig opstod det, som C. Wright Mills kaldte klassestrukturens politiske organisation. I særdeleshed småbesidderne blev gennem økonomiske subventioner og ideologisk manipulation kædet til de store interesser. Dermed besegledes, ikke blot i USA, f. eks. enden på militante antikapitalistiske bønders kooperative organisationer. De $\varnothing$ vrige klassemodsætninger blev tilkittet ved fagforeningernes binding til spillereglerne for en institutionaliseret klassekamp, af de små offentlige tilskud og den store ideologiske manipulation - fra den autoritære børneopdragelse over forfremmelseskonkurrencen til konstruktionen af en indre og yde fjende (jøder, kommunister, anarkister o.s.v.). Antikommunismens store formel, som bragte den politiske, økonomiske og psykiske integration på en fællesnævner, er ganske vist siden slutningen af halvtresserne blevet skrøbelig.

Af grunde, som de kritiske økonomer kan forklare, er den politisk og psykologisk organiserede kapitalismes system trådt ind i en muligvis årtier lang kritisk fase. Ganske vist har stederne i denne sekulære krise forskubbet sig: til de svageste led i kæden, som holder emancipationens kræfter lænket. Statens formelt fulde beskæftigelses- og institutionaliserende klassekampspolitik 
sigtede mod at neutralisere industribedrifterne som primært arnested for uro. Det mislykkedes. Alligevel var følgen en vis nedskæring af de industrielle konflikter og en »eksport « af konfliktstoffet til andre områder, analogt med den imperialistiske eksport af indre konflikter til udviklingslande. Denne fulde beskæftigelse er rent formel, da en stor del af produktivkræfterne spildes i form af slid- og prestigeprodukter, af overkapaciteter og erhvervsgrene, der holdes på et uudviklet stade. Omkostningerne ved denne neutralisering mærker konsumenterne i prisstigningerne og kvalitetsforringelserne og på stilstanden i de offentlige ydelser til fysisk og psykisk handicappede, til trafik og kommunal infrastruktur, til folkepensionister og unge under uddannelse. For borgerlige $\emptyset$ konomer er den moderne form for systemtruende krise kendetegnet ved fænomenerne: snigende inflation og modsigelsen mellem privat velstand og offentlig fattigdom - 'private opulence' og 'public squalor'. ${ }^{3}$

Men dermed er blot fremstillet den forskydelse eller områdeopdeling af krisen, som er formidlet over det politisk organiserede $\varnothing$ konomiske kredsl $\varnothing b$. Utilfredshed opflammes ikke blot af materielle standards, som kan måles endimensionalt i penge, men langt intensivere gennem de kvalitative krav, man stiller til livet. Og her heller ikke blot af de tings og ydelsers tarvelige beskaffenhed, som stat og arbejdsgivere tilbyder én til brug, men også af selve de menneskelige relationers usselhed. Hvilken behandling menneskene føler er ydmygende, uretfærdig, unfair eller uværdig, afhænger af deres sociokulturelle værdiforestillinger. Disse er ganske vist, incl. de af familien prægede karakterstrukturer, også » ske disciplinering, men ofte også et modbillede over for den. Således kan f. eks. det tidlige proletariats rebelske karakter ikke alene forklares ud fra den materielle elendigheds fysiske uudholdelighed. Den industrielle revolution var psykisk uudholdelig, fordi den på alle livets områder negerede traditionelle værdiforestillinger om individuel autonomi og gensidig solidaritet. I senere arbejdergenerationer blegnede denne erindring under de mangfoldige tvangsforhold, som lod præstationskonkurrence og behovsudsættelse, opsynshierarkier og afhængighed fremtræde for dem som uafvendelige naturnødvendigheder. Naturnødvendigheden af mangelsamfundets adfærdsmønster bliver, ansigt til ansigt med den uhyre samfundsmæssige rigdom, stadig vanskeligere at indse. Her ligger en chance for remobiliseringen af antikapitalistiske kulturelle værdiforestillinger på et højere historisk stade. Den kapitalistiske overproduktion af varer svarer til en overproduktion af behov. Den der vil sælge varer, kan ikke prædike askese. Om disse varers og behovs repressive form er der sagt meget. Men overflodsfænomenet indeholder, som den nye sociale bevægelse viser det, også modsigelser, som forandrende praxis kan tage udgangspunkt i. Også mange »dårlige « behov, som behovet for individuelt avancement, kan systemet ikke tilfredsstille.

3. Udtryk hos J. K. Galbraith. O.a. 
Tre fænomener bliver betydningsfulde: fordelingssfæren som ny kampmark, studerende ungdoms avantgarderolle og hierarkiernes almene disfunktionalitet. Mens lydighedsreglerne og arbejdskonfliktens institutionaliserede form pga. angsten for at miste arbejdspladsen endnu eftertrykkeligt sanktioneres i arbejdsprocessen, er det for straftrusler frie aktionsspillerum i konsumsektoren betydelig større. Den Nye Ungdomsbevægelses folkelige aktioner har her fundet en uventet, omend flertydig resonans. Denne ungdomsbevægelse dokumenterer på sin side noget mere end den sædvanlige generationskonflikt: historisk videreførende kulturelle værdimønstre. Mens den foregående generation dybt har internaliseret mangelsamfundets renonceringsvaner, bliver samfundets rigdom og deres $\emptyset$ nskers opfyldelighed tidligere bevidst for de yngre. Den askestiske præstationstvang bliver meningsløs i de udstrækning, behovstilfredsstillelse bliver opnåelig allerede her og nu og ikke først efter årelang afholdende stræben. Samtidig synes deres adfærd i autoritetskonflikter, muligvis også som følge af forandrede familiestrukturer, at være mindre præget af angst.

De hierarkiske beslutningsstrukturers legitimationskrise begrænser sig, som Hillmann og Frielinghaus har analyseret dem, ikke til arbejdsprocesserne i de formelle produktionsinstitutioner med deres bureaukratier, men omfatter som alment spændingsforhold, der udfolder sig over ledelses-, afhængigheds- og rivalitetsrelationer, også alle øvrige gruppeprocesser. Her, i de »små k kampe, hvor det bliver »personligt «, struktureres energierne, der omsættes i de store kampe som såkaldt politisk handlen. I de førpolitiske gruppeprocesser, i hvilken den i den personlige moral internaliserede kapitalisme bliver tematisk, afsløres mere om politiske sindelag end i propagerede bekendelser.

Den formelle pacificering af industriarbejdernes klassekamp har i mellemtiden vist sig at være en begrænset succes. Siden slutningen af halvtresserne har der været massestrejkebevægelser eller -stemninger i Belgien, England, Norditalien, Nordspanien, Vesttyskland og Frankrig. Den deri indeholdte styrke kræver en ny fortolkning ud fra de franske begivenheder. Disse periodisk tilbagevendende, uplanlagte og epidemiske bevægelser blev delvis formidlet af lavkonjunkturer og delvis af mere langsigtede økonomiske tendenser såvel som politiske begivenheder. Recessioner lader sig simpelthen forudsige: de udløses for det meste midt i lovgivningsperioder gennem statsintervention. Om de andre betingelser ved vi for lidt. (Jeg vender senere tilbage til den industrielle konflikts dynamik).

Med denne topografi af krisesteder, der kun kan være foreløbig og skitserende, vil jeg ikke komme med nogle forudsigelser om, hvilken side, der kan afgøre konflikterne for sig. Det er et praktisk spørgsmål. Også den nu følgende inddeling af krisers forløb skitserer kun muligheder.

\section{Kamp- og indlaringscykler}

Påstanden om, at kapitalismen (som også andre ikke-solidariske systemer) er trådt ind i en kriseagtig periode, der må anslås at vare adskillige årtier, behøver 
forskellige kvalifikationer. For det første har den sekulære krise i industrilandene ikke den katastrofale form, hvormed den rammer folkene i de Tredje Verden. Det er tvivlsomt, om en ukontrolleret politisk- $\varnothing$ konomisk krise, mage til den verdens $\varnothing$ konomiske krise, overhovedet kan forventes i industrilandene, endsige er ønskelig som forudsætning for revolution: i hvert fald kan denne mulighed foreløbig udelukkes. Den eskatologiske forestilling om en »revolution«, der som en rengørende flammestorm kan forny alting og skænke menneskene løsningen på alle deres problemer, kan bedre forstås som en projektion af indre fortvivlelse end som produktet af en samfundsanalyse. Jeg opfatter snarere denne kriseperiode som en langvarig fremadskridende kamp- og læreproces, der forløber i cykliske fremstød.

Realiseringen af merværdien i den makroøkonomiske proces, realiseringen af autoritetshierarkiet i arbejdsprocessen og realiseringen af asketiske kulturmønstre i behovssfæren har altid været kapitalismens hovedproblemer. Påstanden om, at en ny sekulær krise i kapitalismen er begyndt, lader sig ikke begrunde bare derved, at disse problemer endnu eller i voksende målestok er bestemmende. Det væsentlige spørgsmål er, om de herskende stadigvæk har integrationsformler, ved hjælp af hvilke uroen fra de berørte mennesker virksomt kan neutraliseres eller holdes tilbage. I mangel af en omfattende analyse af de nuværende klassekampe kan jeg kun nævne indicier på integrationskraftens svækkelse. Systemets sårbarhed er taget til, forsåvidt som protester eller regelkrænkelser, som man i begyndelsen af tresserne simpelthen kunne forbigå, i dag udløser uforholdsvise overreaktioner hos de herskende og vide kædereaktioner i befolkningen. Tillige bliver de politiske, $\varnothing$ konomiske og kulturelle strukturproblemer på trods af enighed om deres eksistens i den grad forhalet og skubbet omkring, at de udvider sig til stadig flere områder. (Teknokratiske løsningers integrationskraft bliver muligvis overvurderet). Det eneste redskab, der blev videreudviklet, er det dummeste: voldens redskab. Jeg definerer altså krisen som en, af de herskende klasseinteresser betinget, manglende indlæringsevne, som ikke kan overvindes med kort frist.

Når et system befinder sig i en langsigtet krisesituation, så betyder dette endnu ikke, at det hele tiden må være lige sårbart. Årtierne af kriseagtige historieperioder kan forstås som en række kamprunder, afbrudt af roligere år. Dette lader sig frem for alt eftervise $i$ den industrielle revolution, $i$ hvilken arbejderklassen kæmpende konstituerede sig selv og sin solidariske samfundsutopi. De middelfristede kampcykler var samtidig de deltagende sociale klassers indlæringscykler, om man vil: tilbagekoblingscykler mellem deres teori og deres praxis. En cyklus' typiske forløb kan skitseres på følgende måde. I den praktiske konflikt bringer enhver klasse en »teori« med for at »afprøve « den. Teorien manifesterer sig f. eks. i forventninger om udfaldet, reaktionsmønstre, bedømmelser af modstanderen og målkonceptioner. Erfaringerne om gode resultater og nederlag, som ved slutningen af en konflikt bliver overskuelige, tilskynder til at korrigere den gamle teoris og organisationsmådes utilstrækkeligheder. 
Denne opgave tilfalder så enhver klasses skrivende intellektuelle. Nu kommer det an på, hvilken klasse, der er den mest lærenemme: i hvilken grad de intellektuelle og de mere praktiske medlemmer af en given klasse har råd til at påtage sig nye indsigter og organisationsmåder. Det således erhvervede bliver til våbnet, der bestemmer forløbet af den næste konflikt.

I kapitalismens hidtidige historie har disse kamp- og indlæringscykler føjet sig sammen til serier af adskillige årtiers varighed, ved hvis slutning den kapitalistiske klasse hver gang havde lært at finde en ny strukturorganisationsformel for det samlede system, at genoprette kapitalismens stabilitet på et højere niveau. Kapitalismen gik i 1848 så styrket ud af den første lange kampperiode den industrielle revolutions borgerkrigslignende klassekampe - at den ved slutningen af den anden periode omkr. 1890 kunne institutionalisere en relativ bestandig $\varnothing$ konomisk udvikling og en relativ integration af arbejderklassen. Den tredje periode, kendetegnet af krisen i den imperialistiske markedsstabilisering, af store krige og af massestrejkebevægelser, som i de kapitalistiske randstater vandt revolutionær kraft, var i sig selv igen så ustabil som den første, og den sluttede, som den første, i en ny kapitalistisk formel for statslig markedsstabilisering (keynesiansk statsintervention) og institutionalisering af klassekonflikten: kapitalismen havde begrebet den opfordring til at tage ved lære, som rettedes mod den af den verdensøkonomiske krise. I dag, da den fjerde lange kampperiode - med udmattelsen af disse ingrationsmekanismer (ikke kun de indenrigs-, men også de udenrigspolitiske, fremfor alt over for den Tredje Verden) - er trådt ind i sit kritiske stadium, stillet sig påny spørgsmålet om, hvilken klasse, der er den mest lærenemme, d.v.s. bedst egnet til magtkamp.

Prisen for sådan en indlæring er rigtignok ikke kun omtankens sved. Kapitalismen måtte først empirisk gennemgå den i den anlagte katastrofe i skikkelse af to imperialistiske krige, som det kostede den halvdelen af dens eurasiske indflydelsesområde, (de myrdede mennesker kunne den lettere forvinde). Kun nogle få nationer med en noget mere udviklet demokratisk kultur kunne spare sig omvejen gennem barbariet. Den statsinterventionistiske integrationsformel blev ofte fundet, ikke fem minutter i tolv, men først fem minutter over tolv. Og denne formel har også kun bragt en interimperiode med relativ stabilitet i fyrrerne og halvtresserne. I den udstrækning som de gamle modsætninger igen bryder op, stiller sig påny for kapitalisterne alternativet mellem en velfærdsstats-kapitalisme eller en mere eller mindre åben fascistisk kapitalisme.

Når jeg med denne periodisering knytter mig til de lange vækstb $\emptyset$ lgers $\varnothing$ konomiske teori, de såkaldte Kondratieff-cykler, så er det ikke for ligesom at finde naturlove, uafhængige af menneskene. Tværtimod er de økonomiske cykler først og fremmest udtryk for en klasseadfærd, som ganske vist stabiliseres i visse institutionelle strukturer og egne lovmæssigheder og forsåvidt er forudberegnelige. Denne stabilisering drager dog atter og atter sig selv i tvivl gennem de af den selv fremkaldte manifeste strukturkriser. Strukturkriser er læreopfordringer. 
Hvis et system f. eks. så ikke ændrer sine strukturer, men følger »bandeførere«, må man regne med, at disse kriser igen og igen over længere tid vil bryde åbent frem med forøget voldsomhed og altså vil danne en sekulær kriseperiode.

Men det er tænkeligt og i visse teknokatiske reformmodeller også anlagt, at denne periode ikke vil bliv sluttet af en agoni, men af en revideret kapitalistisk integrationsformel. Så længe denne formel ikke er realiseret, kan en som alternativ struktureret modmagt udvikle sig med chancer for gode resultater for hele samfundet. Det følgende afsnit er helliget denne modmagtspolitik.

\section{Organiseringen af modmagten}

For at udnytte krisesituationer til forandringer må den emancipatoriske klasse også erhverve bestemte færdigheder i de kampe, som den fører i stabilere tider. Sådanne kampe kan ikke kun have betydning ved, at den i dem erhvervede kunnen først anvendes og belønnes i en revolution. Tidsperspektivet for en sådan asketisk læreproces, der kun kender intellektuel belønning og skyder nydelsen af virkelige gevinster ud i en uoverskuelig fremtid, er hverken til at forlange eller overhovedet empirisk mulig.

\section{Solidarisering i ikke-revolutionare situationer}

Daglige kampe opflammes hyppigt af små misforhold og føres i begyndelsen med det mål at opnå et mindre delresultat, der umiddelbart kan konsumeres. Videre mål bliver først efterhånden tydelige i den udstrækning, kampen udvider sig. Når eksempelvis en militant afdeling i en bedrift vil strejke, må den først reducere sine indbyrdes differencer (statusgrupper, lønforskelle, beslutningshierarkier, informationsmonopoler o.s.v.), der splitter den, for at solidarisere sig til en handlingsenhed og afsvække »Del-og-Hersk «-princippet, det betydeligste repressionsinstrument. Nødvendigheden af sådan solidarisering læres for et meste først i kampen og gennem erfaringer om nederlag. Under pres fra en tilspidsende kampsituation kan der så erhverves indblik i nødvendigheden af at udvikle kommunikationen med bedriftens funktionærer, med andre producentgrupper i virksomheden, i branchen, i regionen o.s.v. Samtidig kan målsætningen udvides fra kamprunde til kamprunde, f.eks. bevæge sig fra julepenge til kritik af det politisk- $\varnothing$ konomiske system. Dette solidariserings- og radikaliseringsmønster under pres fra en kampsituation kunne, som ansatser, iagttages ved Hanomag-strejken 1967. Denne strejke var åbenbart også signal og opmuntring til en videre serie vilde strejker, hhv. voksende strejkestemning i omegnen. Det samme gjaldt for de spontane strejker i efteråret 1969.

En sådan eskalationsproces bryder som regel af på et bestemt sted og løber tilbage. Det punkt, hvor man må finde sig i et kompromis eller et nederlag, bestemmes af, hvilken side, der har lært at organisere sine kræfter bedst. Dette punkt kan, efter tilsvarende læreprocesser, i en senere kampbølge drives længere ud. Arbejdernes kampfærdighed afhænger bl.a. af minimeringen af deres indbyrdes 
konkurrence; af deres materielle og moralske udholdenhedsformåen; af »forstyrrelsesmultiplikatoren « (i højtorganiserede systemer har en lille forstyrrelse af den $\varnothing$ konomiske proces adskillige yderligere forstyrrelser til følge); af den lærte evne til selvvirksomme kampe; af bureaukratiseringsgraden af arbejdernes officielle organisationsspidser; af kvaliteten og kvantiteten af de for arbejderne ikke fremmede kadrer; af i forvejen tilkæmpede magt - hhv. retspositioner. Denne opregning er - det må understreges - fuldstændig utilstrækkelig, opkaster talrige nye problemer. (Til spørgsmålet om »udholdenhedsformåen « måtte det f.eks. undersøges, hvorvidt nederlag til en bestemt grad gør kampmoralen militantere, men derefter lammer den). De herskende relative magtposition er ligeledes komplex og kan ikke ses alene af konjunkturstillingen eller den disponible fysiske magt.

Den asketiske klassekamp-indlæringsteori bedømmer delsuccesser som integrationsmidler, som binder den emancipatoriske klasse tættere til det herskende system og tilslører klassemodsætningerne. Denne opfattelse implicerer på den ene side det umulige alternativ, at delgevinster skulle forbydes. På den anden side underkender den, at delgevinster i et repressivt samfund ikke medfører nogen permanent pacificering af klassekampen, at de samfundsmæssige modsigelser snarere med dem reproduceres på et nyt niveau, og at den forbigående integration følgelig kan og må gennembrydes. Rigtignok spiller kvaliteten af disse delsuccesser en væsentlig rolle derved: hvis de ikke medfører nogle forandringer af beslutningsstrukturer, så er den bevirkede temporære integration vanskeligere at gennembryde. Der må skelnes nøje mellem resultater, der tilfredsstiller konsumtionsbehov og resultater, der tilfredsstiller behov for selvvirksomhed. Den traditionelle lønkampform neutraliserer den revolutionære karakter af produktivkraften arbejde, idet den ikke gør beslutningsstrukturer til kampens genstand. Dette kan på den ene side føres tilbage til ideologien om, at arbejderen kun harmes over »det $\varnothing$ konomiske « og ikke også over at måtte adlyde, og på den anden side til den traditionelle arbejdsdeling mellem parti og fagforening. Ifølge den er ændringen af magtforhold et »politisk « spørgsmål, som må overlades til partiet med dets medbestemmelses- eller socialiseringsplaner. Fagforeningerne må kun tilkæmpe sig, hvad der passivt kan konsumeres: løn, fritid, sundhedsbetingelser på arbejdspladsen, socialydelser fra virksomheden og lignende. En for stor selvstændighed i producentgrupperne ville endda komme i modsætning til selve fagforeningsorganisationens autoritetshierarki. Konsumgevinster er nødvendige, men ikke tilstrækkelige. De lader den paternalitiske struktur være og underst $\varnothing t t e r$ fortrængningsprocessen, der lader arbejdere klage over lønninger, når de mener ufrihed. Det er ikke tilfældet, at denne fortrængning forsvinder $\mathrm{i}$ angstfrie situationer, f.eks. under beskyttelse af solidariteten i en kamp på angrebsstadiet, og magtspørgsmålet bliver vigtigere end lønspørgsmålet.

En ekspansiv lønpolitik som løftestang mod merværdiprincippet er det ikke vanskeligt at neutralisere: ved at vælte omkostningerne over på priserne. Løngevinsten i den franske maj er allerede fortæret. Selvvirksomhed kan ikke organi- 
seres vilkårligt gennem militante kadrers »uformelle grupper«. Grundenhederne i en modmagt inden for bedriften kan ikke være grupper af agitatorer, der er spredt over bedriftens forskellige afdelinger og kun efter fyraften kan danne en kommunikerende forsamling. Selvvirksomhed er på langt sigt kun mulig, når den retter sig efter den produktionsfordelende kooperation i bedriften (eller $\mathrm{i}$ andre institutioner). Den betydeligste chance for arbejderne ligger $\mathrm{i}$, at de med Nægtelsen som middel udnytter deres integration i den samfundsmæssige arbejdsdeling til at gennembryde deres integration i de samfundsmæssige herskerforhold. Her kommer det an på, at de fra arbejdsgivernes bundt af beslutningsbeføjelser tilkæmper sig kontrolrettigheder, som de selvbestemmende (og ikke sammen med arbejdsgiverne, med bestemmende) kan varetage. Et eksempel på dette er mandskabssystemet på Standard Motors værkerne i Coventry, hvor producentgrupperne i bedriftens enkelte afdelinger forvalter fremstillingsprocessen autonomt, d.v.s. uden opsyn af foresatte fra ledelsen. Dette system har sine integrerende aspekter, forsåvidt som producentgruppen pga. en kollektiv præstationspræmie (som den ganske vist efter egen beslutning fordeler mellem medlemmerne), er interesseret i den (private) virksomheds produktivitet. På den anden side har producentgruppen vundet en operationsbasis, hvorfra den kan gribe efter videre kontrolområder, f. eks. virksomhedens investerings- og afsætningspolitik. Dette er også blevet forsøgt med megen sagkundskab i en nødsituation med afsætningsbetingede afskedigelser. Ganske vist er det sandsynligt, at metoden: at fortrænge privatejendommen fra bestemte kontrolpositioner ved hjælp af lønkampe og lønoverenskomster, tilsidst støder på så hård modstand, at eskalationen standser og nu kun kan føres til ende med politiske massestrejker.

På den anden side afhænger udfaldet af massestrejker også af, hvilke forvaltnings- og kampfardigheder de arbejdende masser allerede $f \phi r$ dens udbrud har tilegnet sig. Blandt andet måtte følgende tilegnes:

Organisation af produktivkrafterne. Gennem forstyrrelse af kooperationsprocesser (strejker) eller partiel selvforvaltning (mandskabssystemer) lærer producentgrupper selvstcendigt at forvalte komplexe produktionsprocesser. Dertil er ikke blot empiriske kundskaber nødvendige, men også forestillinger om urealistiske kontrolmuligheder. Der må erhverves såvel teknisk know-how som utopisk fantasi.

Organisation af kampmidlerne. Tillige må der læres nye kampaktioner, for at udmatte modstanderens kraefter. Når et nyt system opstår som modmagt i et herskende systems skød, så må denne modmagt være sig bevidst, at den på de konventionelle kamppladser og med de konventionelle kampvåben er underlegen og til stadighed kan ødelægges. Også her må knowhow og fantasi kombineres for alt efter styrkeforholdene at kunne reagere hurtigt og fleksibelt. I ugunstige situationer kommer det f. eks. an på behændigt at vige tilbage, at mobilisere modstanderens indre modsætninger mod hinanden med det formål at lamme ham, at angribe på uforsvarede fronter, eller på fronter, der ikke kan forsvares, eller overhovedet 
at sørge for, at de herskende kræfter uden resultat selv forbruger deres energi. Ved denne mere defensive taktik, som også ved en offensiv fremgangsmåde er det lige vigtigt at føre konfrontationerne ikke reagerende, men initierende.

Organisation af behovene. Behovene for selvvirksomhed og glæde ved arbejdet som i fritiden er på forskellige måder samfundsmæssigt præformeret eller i det mindste manipuleret, for at neutralisere dem som motiver til revolutionære forandringer. Til klassemodsætningen svarer to modsatte sociokulturelle adfærdsmønstre. Til det herskende konkurrencemønster svarer adfærdsmåder som kamp, avancement, hierarki, atomisering, præstation, askese, ensidighed, autoritetstroskab. Til det mulige solidaritetsmønster svarer adfærdsmåder som gensidig hjælp, lighed, samarbejde, kommunikation, nydelse, ro og mag, selvvirksomhed, udfoldelse, jegstyrke. Emancipationen af behovene er ikke alene nødvendig i bedriften, men også i fritiden, i forbruget, i naboskabet, i seksualadfærden, i moralog retsforestillingerne. Oprindelsen af det »nye menneske« er rigtignok en langvarig proces, som er med til at betinge den lange varighed af revolutioner. Den traditionelle socialisme har næsten gennemgående fortrængt organisationsspørgsmålet på behovsområdet.

Organisation af klassen. Man kan ikke forestille sig arbejderklassen som en homogen formation, men som en historisk proces, i hvilken meget forskelligartede grupper af afhængige - idet de lærer af egne kampe - koalerer, uden dog derved fuldstændig at kunne udjævne alle deres særegenskaber. Derfor kan modmagten ikke organisere sig centralistisk, men kun føderativt. En føderativ rådsstrukturs forudgående former kunne bl. a. være: kooperation mellem arbejdere i produktionen, forvaltningen og produktionsplanlægningen (f. eks. produktionsarbejdere, funktionærer og ingeniører); kooperation ud over bedriften på virksomheds-, branche- eller regionalplan ved arbejdskampe. Frembringelsen af et autonomt kommunikationssystem er imidlertid ikke kun et problem for de forskellige funktionelle grupper og minoritetsgrupper (lærlinge, kvinder, udlændinge), som må ophæve den mellem dem bestående ulighed. Det er også et problem for avantgarderne eller såkaldte kadrer. Denne proces, det er at lære selvvirksomhed, kan ikke på en gang omfatte alle en klasses individer. Først er der nogle få »avantgarder «, der emanciperer sig. Hvis de definerer sig konspirerende eller bureaukratisk, selvstændigg ør de sig på autoritær måde over for dem, hvis emancipation de skulle tjene.

Denne fremstilling er i særdeleshed tilskåret til faglærte arbejdere, teknikere og forvaltningsfunktionærer i storindustrien. Organisationen af modmagt i andre institutioner, særlig de statslige, og i behovssfæren er ikke mindre vigtig. Thi i alle institutioner virker modsigelserne mellem den hierarkiske kommandopyramide og den basis, den hviler på. (Således er det er et fænomen af stor rækkevidde, når de statslige repressionsinstitutioner i dag ikke længer kan forlade sig på deres »personales « lydighed). Jeg taler derfor ikke om arbejderklassen, men om den emancipatoriske klasse. 


\section{Kadrer, apparater og avantgarder}

Den hidtige fremstilling abstraherer desuden fra to vigtige fænomener: fra de etablerede fagforeningers og partiers monopol på den formelle organisation og repræsentation af de afhængige og fra den Nye Ungdomsbevægelses konkurrence med disse bureaukratier. I praxis kan det aldrig ignoreres, at de magtesløses masse i al resignation stadigvæk betragter disse bureaukratier som deres advokater og som deres forsikringsselskaber. Opbygningen af nok så »venstreorienterede« konkurrenceorganisationer ville være meningsløs, da disse - som f. eks. den svenske syndikalistiske fagforening - måtte yde de samme materielle og juridiske forsikringstilbud som de dominerende organisationer for at vinde medlemmer. Selv hvis de overlevede monopolforbundenes $\varnothing$ delæggelsesfors $\emptyset$ g, ville konkurrencens bureaukratiske strukturer igen dukke op i dem. Organisationen af klassen ville muligvis snarere kunne tage udgangspunkt i, at arbejderforbundene står i den samme hierarkiets krise som de øvrige institutioner: at modsigelserne er i institutionerne. Dermed kan jeg imidlertid ikke formulere et løsningsforslag, men kun en problemstilling.

Problemet bliver særlig tydeligt ved, at arbejderne i dag næppe længer har et bredt særegent intelligenslag og ingen lægmandslitteratur, som bestandig står i indbyrdes diskussion og formidler deres hverdagsbekymringer med deres utopi. Kategorierne i den professionaliserede, venstreorienterede intelligens orienterer sig, med undtagelser, snarere efter referencegrupper i fagforeningsapparaternes institutioner, på universiteterne eller i den venstrevendte subkultur. Den fra middelklassen stammende venstreorienterede intelligens kan som regel ikke få $\varnothing j \mathrm{j}$ på de to progressive elementer i arbejderkulturen, forsåvidt den tolket interaktioner efter klassespecifikt anderledes betydningskriterier.

Et eksempel på det var striden om den røde fane og revolutionsparolerne under den hannoverske jernbanekonflikt i juni 1969. Hanomagarbejderne var meget fortørnede over begge dele. Nogle »revolutionære « tolkede dette som kontrarevolutionært. Nogle »reformister « fra DKP og SPD tolkede det med pædagogisk arrogance som bevidsthedens foreløbige umodenhed. Rekognosceringer gav et andet billede. Hanomagarbejderne har også i den seneste tid ofte hentet deres egne røde faner frem. Men de kunne ikke beslutte sig til at tage dem med til en klassemæssigt uspecifik, »fællesfolkelig « protest mod priser: »Det er vores fane. Men man tager den når alt kommer til alt ikke med alle steder hen. F. eks. heller ikke på lokum«. Det kan man strides om. Men i alle fald enedes de med studenterne om, at disse rullede deres faner sammen. Da der så alligevel blev svunget med fanerne, var de ligeså sure over det glemte løfte som over de højreorienterede mennesker, der rev fanerne ned. Ved en senere teachin ville Hanomagarbejdere overdrage en fællesgave på ca. 1500 Mark. Men en retningsstrid om den sande revolutionære linie gav indtryk af, at der dér stredes to grupper om, hvilken en af dem, der skulle give arbejderne hvilke adfærdsbefalinger. Så afleverede de hellere pengene hos IG Metall til en aktionsbestemt 
hjælpefond. Mens den ene part tolkede fanerne og parolerne som »politiserende «, tolkede den anden part dem som middel til at accentuere et ledelseskrav. Og denne anskuelse hviler på den politiske psykologis sidste stade, som ikke kun har opmærksomheden henledt på bekendelser, men også på gestus.

Når de intellektuelle fra middelklassen dog overvinder disse skranker (og det er mange gange lykkedes for dem i aktioner som i Hannover som også i det såkaldte »oplysningsarbejde«), så bliver de ganske vist akcepteret som alvorlige samtalepartnere, men ikke som tilhørende arbejder-subkulturen, fordi de netop ikke lever som arbejdere. Klassefremmede avantgarder kan forsåvidt kun virke derigennem, at de giver eksempler eller signaler og derved udløser adfærdsændringer. Direkte deltagelse i adfærdsændringer ville kun være muligt for et intelligenslag, som er en integreret bestanddel af arbejdernes kulturelle verden. Det meget smalle og ofte gennem rutinepres neutraliserede intelligenslag blandt de ældre arbejdere vil formodentlig på langt sigt blive suppleret op af den nyligt opståede lærlingebevægelse, så snart det lykkes for den, at oversætte de forestillinger, som middelklasse-intellektuelle har konciperet, til dens egen kulturs sprog.

\section{Masseaktioner og politisk magt}

Jeg har hidtil begrænset mig til den førpolitiske organisation og ventet med den »sidste kamp« om den samfundsmæssige magt. I de højtudviklede lande findes der heller ikke noget historisk specifikt eksempel på den, undtagen i nogle træk måske det spanske. Det måtte undersøges, hvorvidt magtspørgsmålet stiller sig i de kvasipolitiske faser af klassekampcyklerne. Jeg mener dermed fasen i en almen konflikt, i hvilken mange mennesker samtidig på forskellige steder viser ulydighed på en bemærkelsesværdig og offentlig måde. Følgende spørgsmål må afklares. I hvilke situationer er masser i stand til det? Hvilke særlige begivenheder giver det sidste stød til forvandling af den latente konflikt til en manifest? Hvilken mekanisme får stadig flere grupper til at tilslutte sig? Hvilken kommunikation forbinder deres handlen? Hvorledes forandres (radikaliseres) kampmidlerne og -målene? Hvorledes kan de foranledige den herskende magt til at opgive sine herskerfunktioner? Hvorledes kan de udfylde det således opståede magtvakuum med egne institutioner? Hvorfor må de igen opgive tilkæmpede positioner, eller hvorledes organiserer Establishment sit modangreb? Hvilke lære- og kampprocesser er mulige efter at bevægelsen er aftaget?

De sidste ti års massestrejker har vist, at sådanne kampbølger stadigvæk bryder ud og forløber som en epidemi. Fagforeningerne eller venstregrupperne har ikke planlagt de franske begivenheder. Teoretikerne har ikke forudsagt dem. Da massestrejker ikke kun begynder under lavkonjunkturer, er motivationerne åbenbart væsentligt formidlet af sekulære krisefænomener. For at den apati-fremkaldende angst forsvinder, må der åbenbart indtræde begivenheder, der lader de herskende institutioner fremtræde som svage. Opnåelsen af det ene eller det andet eksempel (f. eks. gode resultater for en producentgruppe eller en 
studentergruppe) eller fejlreaktioner (som f. eks. for hurtig angreb eller tilbagetrækning), i hvilke Establishment viser sin usikkerhed. Udbredelsen af konflikten formidles åbenbart i mindre grad af de revolterendes direkte kontakt end af institutionelle publikationsmedier (statens, fagforeningernes o.s.v.). Solidariseringen formindsker angsten sådan, at de afhængige i næsten alle institutioner vover Nægtelsen. En direkte kommunikation kommer næppe i stand. Thi aktørerne har ikke forberedt den, og de officielle arbejderorganisationer tilintetgør den. Establishment giver afkald på det militære forsvar af gaderne, kulturinstitutionerne og bedrifterne, det eneste alternativ til et blodbad. De rømmede pladser bliver taget i besiddelse af de hidtidige undersåtter. Og det som forsamlingssteder, som steder for den Store Selvforståelse. Generalstrejken begynder, som William Benbow 1832 som den første konciperede den, som den Hellige Måned for den nye opdragelse og diskussionen om det ny samfundssystem, som alle ved månedens slutning skal flytte ind i. Men selvforståelsen er begyndt for sent. Den nye produktions-, fordelings-, kultur- og kommunikationsorganisation bliver i bedste fald praktiseret eksperimentelt. Hånden griber efter magten, men fingrene lukker sig ikke om den. Regeringen, hvis myndigheder og tropper havde ventet ugeneret i deres bygninger, tilbyder revolten erstatningsmål som lønforhøjelser, en mere social paternalisme og nyvalg. De officielle arbejderorganisationer begynder at forhandle. Ved hjælp af deres kommunikationsmonopol lader de epidemien svinde ind på samme måde, som den var vokset frem. Falske meldinger om producentgrupper, som skulle have afsluttet strejken, indleder afsolidariseringen og tilbagevendingen af angst. Dermed opstår også skyldfølelser hos dem, der er blevet grebet i ulydighed, som driver vælgere hen til de regerende og masser af hidtil uorganiserede arbjdere hen til fagforeningerne. Men tillige begynder en mange måneders lang bølge af småkampe, der fortsætter det begyndte i mindre målestok, mere som gruppe end som masse.

Gademasser eller forsamlingsmasser er ikke organer for et kommende samfund. Deres funktion kan måske betegnes som negationen af infrastrukturen. Sådanne masser kan ikke præstere meget mere end at give en protokol over de forudgående læreprocesser. Kun organiserede masser, som gennem mindre praxis har lært at realisere direkte med hinanden kommunikerende selvforvaltningsorganer, kan fastholde magt eller stabilisere gode resultater. Da arbejderne også ved massestrejker snarere strømmer ind i traditionelle end i nye organisationer ville eksistens af uofficielle kritiske kerner inden for disse apparater måske snarere nytte end skade deres gensidige information såvel som omsættelsen af deres impulser på politisk plan. Tillige ville der kunne opstå en direkte kommunikation mellem bedrifterne.

Spørgsmålet om den organiserede statsmagt er forblevet fuldstændig uafklaret. Havde en modregning i Frankrig været mulig, som havde kunnet sikre de sociale resultater politisk og udenrigspolitisk? Havde den bestående regering efter dens manipulationsmidlers svigten, søgt den militære afgørelse på gaden? 
Sikkert er det i hvert fald, at massestrejkebevægelsers styrke ikke er den fysiske magt. Deres styrke er netop Nægtelsen, og deres chance er, at Nægtelsen kunne forplante sig til statsmagtens kræfter.

Uløst er også problemet om udenlandske interventioner, som den internationalt sammenfattede kapital kan gribe til over for udbrydende nationer. En metode er den internationale finanspolitiske afpresning, som hindrede regeringen Wilson i de få strukturforandringer, som denne selv engang ønskede. En militærintervention, som den fandt sted i Grækenland og truede i Italien, er ligeledes endnu historisk mulig. - Heroverfor har massestrejkerne i årtier gjort holdt ved de nationale grænser. International solidarisering fandtes i den seneste tid kun hos studenter. En solidarisering blandt de europæiske arbejdere mod virksomhedernes, regeringernes og Fællesmarkedets politik er kun mulig, hvis de bestående sporadiske kontakter mellem de mellemliggende arbejderog fagforenings-»kadrer« bliver udbygget til et direkte kommunikationssytem.

Man må regne med, at massestrejkesituationerne periodisk vender tilbage i de europæiske lande. Før den emancipatoriske klasse kan udnytte sådanne situationer til virkelige strukturændringer, må den formodentlig gentagne gange have gennemgået dem og besidde hoveder, som kan tjene den ved forklaringen af dens erfaringer og tilegnelsen af nye adfærdsmåder.

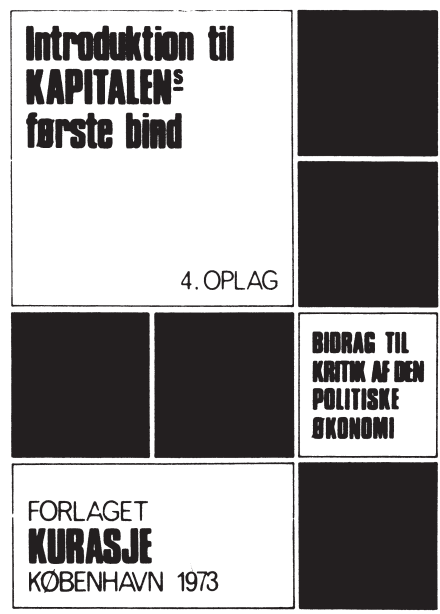

\section{INTRODUKTION TIL KAPITALENS FøRSTE BIND}

Udarbejdet som en grundig pædagogisk indføring i Kapitalens problemstillinger af en gruppe tyske historiestuderende. Den indeholder som tillæg et arbejdsmateriale, som skal lette forståelsen af begreber og problemer i Kapitalens første bind.

222 sider, pris $14.00 \mathrm{kr}$.

$\mathrm{Nu} 4$. oplag - ialt 12.000 expl. 


\title{
Om begrebet statsmonopolistisk kapitalisme
}

\author{
Paul Mattick
}

I forbindelse med begrebet statsmonopolistisk kapitalisme er der i første omgang kun tale om en korrekt beskrivelse af de eksisterende samfundstilstande. Kapitalismen er gennemtrængt af monopoler og bestemmes i høj grad af disse. Staten som skal beskytte samfundsstrukturen er dermed den monopolistiske kapitals stat. Der er imidlertid ikke tale om en fuldstændig samfundsmæssig nyskabelse men om en tilstand, der også karakteriserede den tidligere kapitalisme, omend i mindre udpræget form. Ifølge Marx, som har givet os den bedste analyse af kapitalismen, forudsætter den kapitalistiske konkurrence selv monopolet, nemlig det kapitalistiske monopol til produktionsmidler.

\section{»Monopol« og »konkurrence«}

De antagonistiske klasseforhold, som udspringer heraf, nødvendiggør statsmagten, som samtidig repræsenterer kapitalens nationale interesser i den internationale konkurrence. En ren konkurrencekapitalisme eksisterede tidligere kun i den borgerlige $\varnothing$ konomis fantasier og modeller. Men også her talte man om naturlige monopoler og monopolistiske priser. Selv om monopolerne ikke var underlagt markedslovmæssighederne var de dog ikke i stand til at påvirke disse lovmæssigheder væsentligt. 
Først sent, efter at hele industrigrene var monopoliseret, så selv den borgerlige $\varnothing$ konomi sig tvunget til at inddrage eksistensen af herskende ufuldstændig eller monopolistiske konkurrence i deres teorier og til at komme ind på de monopolistiske modifikationer af markedet.

Hvad der tog sig ud som en teoretisk vending for den borgerlige $\emptyset$ konomi, udgjorde i den marx'ske kapitalanalyse en fra begyndelsen iboende udviklingstendens i den kapitalistiske akkumulation. Kapitalernes konkurrence fører til deres koncentration og centralisering. Fra konkurrencen udvikler monopolet sig ligesom den monopolistiske konkurrence. Ligeledes får staten en stadig større betydning i den marx'ske teori, end hvad den borgerlige verden selv indrømmede den - ikke kun som understrykkelsesapparat men også som banebryder og beskytter af den kapitalistiske ekspansion. Der kan således ikke indvendes noget mod begrebet statsmonopolistisk kapitalisme, selv om det ikke siger mere end slet og ret kapitalisme. Man kan i denne forstand skelne mellem forskellige udviklingstrin i monopoliseringen og den statslige indvirken på økonomien.

Kapitalismens udvikling lader sig på denne måde bestemme som dens udvikling til statsmonopolistisk kapitalisme, og spørgsmålet rejser sig hvad det betyder for den øjeblikkelige situation og den nærmeste fremtid. Det er her, at den særlige understregning af den nuværende kapitalismes statsmonopolistiske karakter får betydning.

Den kapitalistiske akkumulation rummer ikke blot en tendens til fremadskridende samfundsmæssig klasseadskillelse mellem arbejde og kapital, men også en tendens til tiltagende koncentration og centralisering af magten til at råde over den kapital der forøger sig selv. »En kapital slår mange ihjel «; hvad koncentrationen formidlet gennem konkurrencen ikke er i stand til at opnå, det lykkes for den bevidste centralisering gennem trust-, karteldannelser og monopolisering. Kapitalismen befinder sig således under vedvarende forandring på grundlag af de kapitalistiske udbytningsforhold.

For Marx var kapitalismens undergang allerede indbefattet i dens opkomst. De samme samfundsmæssige forhold som muliggjorde dens ekspansion bestemte samtidig dens nedgang. Kapitalens akkumulation var en proces gennemsyret af kriser. Under en udviklet kapitalismes betingelser - hvor arbejderstanden var den udslagsgivende klasse - rummede hver store krise muligheden for social revolution. Ser man imidlertid væk fra mulighederne for en revolutionær løsning på de kapitalistiske modsigelser, så fremstår den tiltagende monopolisering af den nationale $\varnothing$ konomi og den skærpede internationale monopolistiske konkurrence af de kapitalistiske udviklingstendenser - på trods af og ved hjælp af alle tilbageslag i kriseperioderne.

\section{»Monopol« og »Socialisme«}

Denne udvikling blev ofte betragtet som en forberedelse til socialismen, der fuldbyrdes objektivt. Med overgangen fra konkurrencen til monopol - de store 
kapitalenheder frembragt gennem akkumulationen, koncentrationen og centraliseringen - ændrede den kapitalistiske privatejendomsret til produktionsmidlerne sig til aktieselskabers og store koncernes kollektive ejendom, hvor ledelsen af virksomheden ikke længere faldt sammen med ejerne. For Marx var dette »ophævelse af den kapitalistiske produktionsmåde inden for den kapitalistiske produktionsmåde selv, altså en modsigelse, der ophæver sig selv, og som prima facie (umiddelbart) præsenterer sig som simpelt overgangspunkt til en ny produktionsform. Den manifesterer sig som en sådan modsigelse i sin fremtrædelse. Den skaber i visse sfærer et monopol og opfordrer dermed til statslig indblanding. Den frembringer på ny et finansielt aristokrati, en ny slags parasitter i skikkelse af projektmagere, spekulanter (Gründer) og rent nominelle direktører; et helt system af svindel og bedrag ved hjælp af selskabsstiftelse, aktieudstedelse og aktiehandel. Det er privat produktion uden den private ejendoms kontrol.« (Das Kapital, III, MEW 25, s. 454, da udg. bind 3, s. 570).

Selv om denne tilstand var udtryk for det kapitalistiske forfalds fuldbyrdelse, så tilskrev Friederich Engels det også en positiv side. Det var den planløse kapitalistiske produktions kapitulation over for det socialistiske samfunds planmæssige produktion. Efter hans opfattelse var der her tale om et »modtryk fra de vældigt udviklede produktivkræfter mod deres kapitalegenskab« og om en »tiltagende tvang til at anerkende deres samfundsmæssige natur, som tvinger kapitalistklassen selv til mere og mere at behandle dem som samfundsmæssige produktivkræfter, for så vidt dette overhovedet er muligt inden for kapitalforholdene.«

Engels er under alle omstændigheder her klar over, at »hverken forvandlingen til aktieselskaber eller selv til statsejendom opløser produktivkræfternes kapitalegenskaber. «I forbindelse med aktieselskaber er dette åbenlyst og hvad angår staten: $»$ jo flere produktivkræfter den overtager som sin ejendom, desto mere bliver den virkelig totalkapitalist, desto flere statsborgere udbytter den. Arbejderen forbliver lønarbejder, proletar. Kapitalforholdet bliver ikke ophævet, det bliver tværtimod sat på spidsen. Men på spidsen slår det om. Statsejendommen til produktivkræfterne er ikke løsningen på konflikten, men den rummer i sig løsningsmuligheden.« I og med at den kapitalistiske produktionsmåde »har trængt forvandlingen af de store samfundsmæssiggjorte produktionsmidler over i statsejendom, viser den selv vejen til fuldendelse af denne omvæltning.« (Anti-Dühring, MEW 20, s. 260). Hvis monopoliseringen og statsliggørelsen af $\varnothing$ konomien hos Engels stadig er en proces ledsaget af kriser, så får den hos Hilferding en rolle der udelukker kriserne, hvorved problemet om socialisme bliver til et rent politisk problem. Selv om byrderne for alle ikkekapitalistiske klasser bliver stadig tungere under den fremadskridende monopolisering, så fører denne proces dog til sidst til en kartelliseret, bevidst reguleret produktion, der begrænser den stadigt eksisterende samfundsmæssige antagonisme til fordelingen. Hvad der derudover skal gøres er den »bevidste regulering af $\varnothing$ konomien, ikke gennem og til nytte for kapitalmagnaterne, men 
gennem og til nytte for det totale samfund.« Finanskapitalens allerede samfundsmæssige funktion - forbindelsen mellem industri- og bankkapital - »letter overvindelsen af kapitalismen overordentligt. Så snart finanskapitalen har bragt de vigtigste produktionsgrene under sin kontrol, er det nok at samfundet bemægtiger sig finanskapitalen gennem sit bevidste eksekusitionsorgan - den af proletariatet erobrede stat - for derved at få rådighed over de vigtigste produktionsgrene.«(Das Finanskapital, Frankfurt 1968, s. 502).

For Hilferding havde finanskapitalen allerede fuldendt den nødvendige ekspropriation af den private kapital, således at statsliggørelsen kun satte den sidste streg under den af kapitalen selv frembragte samfundsmæssigg ørelse af produktionsmidlerne. Denne tanke blev også taget op af Lenin. I sine forskellige arbejder over imperialismen beskrev han den tilstand kapitalismen havde nået ved århundredeskiftet som monopolistisk, parasitær, stagnerende og døende bort. Dette udviklingstrin var karakteriseret ved »overgangen fra den frie konkurrence til den monopolistiske kapitalisme (og gennem) udviklingen af et apparat til den samfundsmæssige regulering af produktionsprocessen og fordelingen af produkterne gennem bankerne og kapitalistorganisationer.« (Werke, bind 24, s. 459). Uden at komme nærmere ind på Lenins imperialismeteori skal det dog bemærkes, at for ham faldt imperialismen sammen med finanskapitalen og udgjorde den organisatoriske forberedelse til socialismen. Den centraliserede rådighedsmagt over den samfundsmæssige kapital gennem den monopolistiske finanskapital skulle kun overtages af den proletariske stat for at kunne bringes til at tjene samfundet.

Denne opfattelse, som går tilbage til Engels og som deles af Hilferding og Lenin (trods forskelle på andre områder), om at monopolkapitalismen på denne måde er banebryder for det socialistiske samfund, bygger på den falske antagelse, at de samfundsmæssige organisationsformer, som kommer frem med kapitalkoncentrationen, er identiske med samfundsmæssiggørelsen af produktionen. Således talte man også om den angivne rationelle og planmæssige organisation af enkeltvirksomhederne overfor den totale økonomis irrationelle og planløse forløb, hvad der foranledigede Lenin til at forestille sig den socialistiske $\emptyset$ konomi som en gigantisk fabrik - ledet af staten. I virkeligheden er enkeltvirksomheden ligeså irrationel som den totale $\varnothing$ konomi, hvis man altså ikke anerkender det kapitalistiske profitmotiv som $\varnothing$ konomisk-rationelt princip for produktionen. De enkelte virksomheder ligger i lige så høj grad under for kapitalens valoriseringslove som hele samfundet, og de fungerer alene indenfor den almene eller monopolistiske konkurrences rammer - og deres organisatoriske former er bestemt herigennem.

\section{»Statskapitalisme« og »Monopolkapitalisme«}

Idet de følger profitmotivet organiserer monopolerne sig heller ikke uafhængigt. Hvis de alle anbringes under statens centrale kontrol, så kan staten kun reproducere dette nye kapitalforhold mellem sig og producenterne, hvis ikke 
disse ikke fjerner staten. Den vedvarende eksistens af såkaldte socialistiske stater har givet det praktiske bevis på, at begrebet socialisme i denne sammenhæng kun dækker over den aktuelle statskapitalisme eller »statssocialisme«. »Socialisme« kan defineres som fuldstændigt socialiseret kapitalisme; i denne forstand udgør statskapitalismen »socialismen«. Statsligg ørelsen af kapitalen afslutter privatkapitalens klasseherredømme. «Samfundsmæssiggørelsen« af produktionsmidlerne er dog stadig kun en statsliggørelse af kapitalen som kapital. Af denne grund eksisterer konkurrencen stadig; den fører kapitalismens samfundsmæssige antagonismer ind i det statskapitalistiske system. Selv om den private kapitalakkumulation nu er udelukket, fortsætter udbytningen af mennesker gennem mennesker dog, fordi der såvel i produktions- som i konsumområdet eksisterer ulige fordeling.

Lønsystemet består stadig; statsbureaukratiet udgør den nye herskende klasse, hvis medlemmer »personificerer« kapitalen. Lønarbejde karakteriserer det statskapitalistiske system i lige så høj grad som det privatkapitalistiske (jvf. P.M. Marx und Keynes, Frankfurt 1971, København 1973, kap. 20, 21).

Denne statskapitalisme kan faktisk - dog kun på revolutionær måde - vokse ud af monopolkapitalismen og så at sige bringe monopoliseringen til dens logiske afslutning. Det fuldstændige monopol over produktionsmidlerne ophæver dog ikke kapitalforholdet, men befrier det for markedskonkurrencen, uden dermed at fjerne konkurrencen selv. Selv bortset fra, at denne uden videre forbliver på internationale områder, så ændrer den inden for statskapitalismen også kun sin form.

På baggrund af statens store rolle i krigs økonomierne under 1. verdenskrig antog Lenin monopolkapitalismen, gennem det dertil hørende imperialistiske imperativ, for en statsmonopolistisk kapitalisme, hvori staten udfører monopolernes ærinder. Dermed blev det næste skridt i retning af socialisme i de kapitalistiske lande frigørelsen af staten fra monopolernes interesser og anvendelsen af staten i hele befolkningens interesser. Rigtignok måtte monopolernes stat ifølge Lenin knuses, for at gøre plads for en ny proletarisk stat, der faktisk er grundlagt på en ophævelse af den kapitalistiske udbytning. Den statsmonopolistiske kapitalisme skulle vige for den socialistiske stat, uden derved at prisgive den statsligcentrale rådighedsmagt over den totale $\emptyset$ konomi.

\section{Angrebspunkter mod den »statsmonopolistiske kapitalisme « i dag}

Med ligestillelsen af statskapitalisme og socialisme som overgang til en statsløs kommunisme, der kan ses henlagt langt ud i det fjerne, så bliver kampen for socialismen til kamp mod den nuværende statsmonopolistiske kapitalisme. Denne kamp kan kun føres revolutionært, eftersom den statsmonopolistiske kapitalisme ikke frivilligt takker af. Selv om udbytningen af arbejderen fortsætter under statskapitalismen, så ødelægger denne dog det bestående borgerlige klasseherredømme. Imidlertid har de kommunistiske partier i de vestlige lande, som i dag tilsyneladende vender sig mod den statsmonopolistiske kapitalisme, 
allerede for årtier siden hørt op med at være revolutionære bevægelser. De er ikke længere parat til at tvinge deres eget program revolutionært igennem, men fører i stedet en skyggeboksning mod den statsmonopolistiske kapitalisme, for at indrette sig inden for dette system og derved at vinde indflydelse.

Dermed er ikke sagt, at disse partier er blevet utro mod deres egne mål. Hvor der viser sig lejlighed til det vil de uden tvivl forsøge at føre enhver fremtvungen anti-kapitalistisk bevægelse over i statskapitalisme. Eftersom sådanne bevægelser endnu ikke står på dagsordenen, anvender de al deres energi på at tilkæmpe sig magtpositioner indehfor det eksisterende samfund. Deres »kamp« mod den statsmonopolistiske kapitalisme forbliver således et tomt propagandaudtryk for at bringe »masserne «, som indtil nu ikke vender sig mod kapitalismen men kun mod dens »dårlige sider«, ind under sig.

Men under kapitalismen eksisterer der imidlertid kun uforenelige klasseinteresser. Derfor kan man ikke vinde de kapitalistisk indstillede samfundslag som falder som ofre for monopoliseringen for socialismen, eftersom deres særlige samfundsmæssige positioner vil blive ødelagt endnuhurtigere og grundigere her end under monopolkapitalismen. På kapitalismens grundlag kan man højest vinde dem for en politik, der lover at varetage deres særlige interesser, dvs en antisocialistisk politik. Bag parolet om kampen mod statsmonopolkapitalismen skjuler der sig således bebudelsen af en kontrarevolutionær politik, rettet mod socialismen.

Det er i hvert fald muligt at forestille sig, at det forstærkede monopolistiske tryk, som trækker proletariseringen af småborgerlige lag med sig, overbeviser en del af disse lag om, at deres sidste chance findes i statskapitalismen, som kan genåbne deres karriere, som er blokeret under monopolkapitalismen. Et blik på de »socialistiske lande« er tilstrækkeligt til at retfærdigg øre denne overbevisning. For arbejderen viser det samme blik imidlertid et andet billede. De længes ikke efter denne form for »socialisme«. De steder hvor den kommunistiske politik spiller en vis rolle, som f.eks. i Frankrig og Italien, ser de af den grund ikke viljen til en revolutionær omvæltning fra statsmonopolistisk kapitalisme til statskapitalisme i denne politik, men kun det politiske forsvar af deres direkte interesser inden for det eksisterende samfundssystem. De kommunistiske partiers funktion er her reformistisk, ikke revolutionær; de tjener dermed i sidste instans opretholdelsen af den statsmonopolistiske kapitalisme.

På baggrund af dette forhold er den tilsyneladende kamp mod den statsmonopolistiske kapitalisme kun en forlegenhedsparole. Det er længe siden at de kommunistiske partier var villige til at angribe kapitalismen selv, hverken på nationalt eller internationalt plan, hvad der viser sig i den »fredelige konkurrence « og de forretningsmæssige forbindelser mellem de forskellige samfundssystemer. På internationalt plan tjener den foregivne kamp mod den statsmonopolistiske kapitalisme den imperialistiske politiks øjeblikkelige krav. Man retter sig ikke mod den kapitalistiske imperialisme slet og ret, men kun mod den statslige im- 
perialistiske politik (som tjener monopolerne i bestemte lande), som modsiger egne nationale eller imperialistiske interesser. Gennem adskillelsen mellem kapitalisme og statsmonopolitisk kapitalisme lader alliancer såvel som fjentligheder mellem »socialistiske « og kapitalistiske lande sig retfærdiggøre, og dermed også forskellene mellem de »socialistiske« lande selv. Med andre ord dækker disses egen kapitalistiske og imperialistiske politik sig bag parolen om kampen mod den statsmonopolistiske kapitalisme, for at kunne spænde arbejderen foran.

Da der fremover - udover fordrivelsen af monopolerne - ikke behøves at blive lavet om på det eksisterende produktionssystem, må dette eksisterende system anses for tilstrækkeligt til socialismen. Deraf stammer den relative mangel på interesse med hensyn til den nuvængende kapitalismes kriselovmæssigheder. Skylden for de endnu vedhængende vanskeligheder og uretfærdigheder tilskrives staten, som har gjort monopolernes interesser til sine egne. Hvad der derfor kræves er en anden stat eller en anden regering, ikke et andet økonomisk system. Også på dette punkt falder den nuværende kapitalismes og statskapitalismes ideer sammen. Statsmonopolkapitalismen bilder sig ligeledes ind at have ophævet kriselovmæssighederne gennem statslige indgreb i de økonomiske mekanismer. Eftersom denne illusion allerede har mistet en overbevisende styrke på grund af den genstridige virkelighed, så opstiller »oppositionen « mod den statsmonopolistiske kapitalisme krav om en mere vidtgående og til sidst fuldstændig statslig beherskelse af økonomien, for at fjerne videre rystelser.

Staten skal ad politisk vej nå hvad det kapitalistiske marked selv ikke mere er i stand til at nå. De statslige indgreb i $\varnothing$ konomien har faktisk tiltaget løbende. Konjunkturperioderne blev derved ført tilbage til den statslige økonomiske politik og der opstod den forestilling, at kapitalismen faktisk lod sig regulere bevidst.

Dette var allerede foregrebet i socialistisk teori. Hilferding skriver f. eks. således: »når de monopolistiske sammenslutninger ophæver konkurrencen, så ophæver de også det eneste middel, hvorigennem en objektiv prislov kan virkeligg øres. Prisen hører op med at være en objektiv bestemt størrelse, og bliver et regnestykke for den, som gennem vilje og bevidsthed bestemmer den. ... Virkeliggørelsen af den marx'ske koncentrationslære, de monopolistiske sammenslutninger, synes dermed at være ophævelsen af den marx'ske værditeori.« (Das Finanskapital, s. 313).

Det overstiger Hilferdings fatteevne, at det i den marx'ske værditeori ikke er priserne selv, men kun det almene prisniveau og dets forandringer, som er bestemt gennem værdiloven. Konkurrencen sigter mod en gennemsnitlig profitrate, der viser sig i prisernes afvigelser fra værdierne. Herunder opstår der ekstraprofitter eller monopolpriser og dette under hele den kapitalistiske udvikling, hvilket udgør en af årsagerne til den udvidede akkumulation. Gennem den fremadskridende monopolisering reducerer monopolpriserne de konkurrerende kapitalers gennemsnitsprofitrate. Det drejer sig her om profitter, som 
bliver overført fra konkurrencens sfære til monopolernes. Med konkurrencens undergang forsvinder også mulighederne for at overføre profitter fra den konkurrerende til den monopoliserede sektor i økonominen; den monopolistiske profitrate bliver til gennemsnitsprofitrate på basis af værdiloven.

Den monopolistiske $\varnothing$ konomi ophæver ikke værdiloven, men stadfæster den gennem profitratens- og dermed akkumulationsratensfald også for den monopolistiske kapital og de dermed forbundne nødvendige statslige indgreb i økonomien. Sådanne indgreb støder imidlertid mod bestemte grænser i de kapitalistiske produktionsforhold og kan derfor kun betragtes som forbigående muligheder. Er disse muligheder udtømt, sætter de kapitalistiske kriselovmæssigheder sig på ny igennem og frembyder igen muligheden for en revolutionær overvinding af det kapitalistiske system. I denne forstand stiller den nuværende kapitalismes statsmonopolistiske karakter ikke proletariatet en anden opgave end kapitalismen i en hvilken som helst udgave, nemlig afskaffelse af kapitalforholdene gennem ophævelse af lønarbejdet i det klasseløse samfund.

Paul Mattick i 'Links' nr. 44, 1973. overs. Finn Hansson.

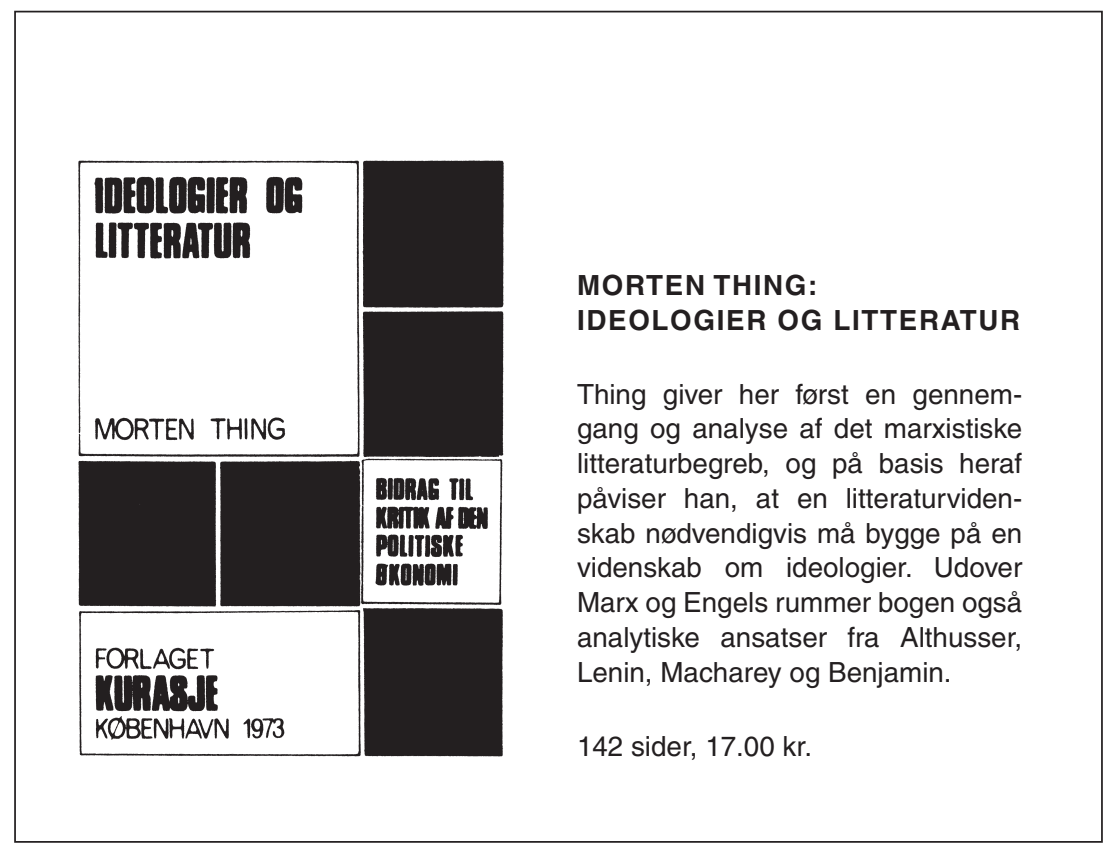




\section{Problemer omkring monopoler og statens rolle*}

\section{Elmar Altvater}

I diskussionen af den politiske taktik ved opbygningen af en antikapitalistisk, socialistisk bevægelse tager Altvater udgangspunkt i forbindelsen mellem den teoretiske ramme og den politiske taktik.

Han påviser, at revisionismens skarpe skel mellem økonomi og politik, mellem lønkamp og politisk kamp fører til en amputering af det revolutionære indhold $i$ analysen af kapitalismen.

Denne amputerings konsekvenser for den politiske taktik viser sig i opfattelsen af statens rolle. De forskellige socialdemokratiske teoretikere og Stamokap-teoretikerne mener nemlig, at »værdilovens regulerende evne er sat ud af kraft «, og at især staten nu står som produktionens regulator.

Hvis staten ikke opfattes som en del af de kapitalistiske bevægelseslove (og derfor lader sig aflede af disse bevægelseslove), men som en erstatning for disse, så bliver den politiske taktik til et spørgsmål om kampen om statsmagten, mod monopolerne og deres forbindelse til statsmagten.

Monopolbegrebet spiller en afgørende rolle for Stamokapteoretikernes påstand om bevægelseslovenes ophævelse, hvorfor Altvater analyserer monopolbegrebet nærmere i det afsluttende afsnit.

Foredrag, holdt i København d. 16.10.1973.

Afsnit V er oversat fra »Probleme der empirischen Analyse der Akkumulationszyklen in Westdeutschland «, Berlin 1972 s. 13-23. 
Analysen af de kapitalistiske produktionsrelationer har politiske implikationer, og omvendt er det meget ofte således, at de politiske mål bestemmer såvel form som resultat af teoretiske overvejelser angående den nuværende kapitalisme. Desuden er arbejderbevægelsens politiske fraktioner og især arbejderpartierne ofte forskellige med hensyn til deres teorier, hvilket resulterer i særlige politiske forestillinger og taktikker. Dette er ret indlysende i diskussionen omkring den sk. STAMOKAP eller statsmonopolkapitalismen. Teorien om statsmonopolkapitalismen er blevet den næsten helt »officielle« teori i de vestlige landes kommunistiske partier og i den socialistiske verden, og en anden opfattelse end de kommunistiske partiers markeres ofte gennem en »anti-teori« om statsmonopolkapitalisme. Eksempelvis er diskussionen i Vesttyskland om STAMOKAP dels en teoretisk diskussion og dels - mere vigtigt - en diskussion mellem det vesttyske kommunistiske parti og venstre-socialister om den politiske taktik ved opbygningen af en antikapitalistisk, socialistisk bevægelse.

Jeg vil gerne vise denne forbindelse mellem teoretisk ramme og politisk taktik ved nogle eksempler.

1. eksempel: I teorierne om statsmonopolkapitalismen læser man almindeligvis, at monopolerne undertrykker og udplyndrer hele samfundet, eller at hele samfundet er underordnet et par monopoler. Det er klart at dette udsagn får konsekvenser for indgåelsen af politiske alliancer. Hvis det er rigtigt, at monopolerne lever af at udplyndre hele samfundet, så må der være en fundamental interessekonflikt mellem monopolkapitalen og dens stat på den ene side og folkets store masse på den anden side. Derfor udvikler STAMOKAP-teorien en politisk kategori om »de antimonopolistiske kræfter « eller bevægelse, som indgår en meget tæt alliance med den revolutionære arbejderbevægelse. Derfor bliver det en meget vigtig opgave for de kommunistiske partier at skabe og styrke brede antimonopolistiske alliancer. Her viser det sig således, at den teoretiske fortolkning af monopolernes profit som tribut eller underkastelse har politiske konsekvenser med hensyn til opbygning af alliancer mellem alle lag og grupper i samfundet med undtagelse af monopolerne og deres stat.

2. eksempel: Ud fra antagelsen om statens relative autonomi som et politisk reguleringsapparat og ud fra antagelsen om denne stats store betydning for monopolernes magt følger, at staten har en dominerende stilling i samfundet, og at staten må erobres af de antimonopolistiske kræfter. Dette er antimonopolistiske kræfters første mål, fordi der er mulighed for at lægge pres på politikken og for at bekæmpe favoriseringen af monopolerne, samt for at gribe ind mod de fjendtlige forholdsregler, som staten gennemfører. Således bliver det et mål for en kommunistisk taktik at gennemtvinge det antimonopolistiske eller fremskredne demokrati for at indføre en anden politik i staten, et andet indhold i politikken, hvor dette nye indhold udledes af de interesser, som hele den antimonopolistiske del af folket har. Også i dette tilfælde har vi således et eksempel på, at en særlig 
teoretisk opfattelse med hensyn til statens autonomi implicerer en særlig politisk opfattelse, nemlig forestillingen om det antimonopolistiske demokrati.

3. eksempel: Lenin og alle de teoretikere, som bygger på hans arbejder, taler om forfaldstendenserne i statsmonopolkapitalismen. Også denne kategori får taktiske konsekvenser. I forhold til kapitalismens forrådnelse, som i dag gennemløber sin »tredje fase af kapitalismens almene krise « bliver socialismen et realt alternativ, som aftegnes i konkurrencen mellem de to systemer i verden. Dette betyder, at de teoretiske udsagn med nødvendighed implicerer politiske udsagn om kapitalismen og socialismen som reale samfundsmæssige systemer. Især i Vesttyskland indebærer denne teoretisk forklarede politiske stilling en accept af Den tyske Demokratiske Republik.

Disse korte eksempler viser, at der er en sammenhæng mellem teoretisk argumentation og formuleringen af politiske doktriner. Derfor er især samfundsvidenskaberne altid politiske i den forstand, at de er i stand til at formulere forklaringer eller udarbejde gode politiske taktikker. Problemet er dog ikke så gensidigt, som det er formuleret her, fordi enhver teori er ikke i stand til at underbygge og bevise en hvilken som helst politisk taktik. Det er omvendt således, at teoriens struktur og politikkens struktur må være kongruente. Dette argument kan belyses ved at diskutere relationen mellem $\varnothing$ konomi og politik i teori og praksis.

II.

Forholdet mellem $\varnothing$ konomi og politik har mange dimensioner. For det første kan det transformeres til forholdet mellem de økonomiske bevægelseslove for kapitalakkumulationen og den politiske magt, som staten eller de samfundsmæssige magteliter udøver. Det er typisk for den reformistiske teori og praksis at understrege den rolle, som magt og modgående magt spiller ved reguleringen af de samfundsmæssige systemer og for at tvinge disse til at gennemføre sociale reformer, f.eks. lønforbedringer, større social sikkerhed o.s.v. Den reformistiske teori mener, at kun den $\varnothing$ konomiske magt kan overvindes af arbejderpartiets modgående politiske magt. Reformismen glemmer det betydningsfulde forhold i den kapitalistiske udvikling, nemlig at systemets modsigelser ikke kun er modsigelser med hensyn til økonomisk og politisk magt, men netop modsigelser af en mere principiel natur, idet de skabes af den kapitalistiske systems modsisesfulde udviklingsmåde.

For det andet er der dimensionen $\varnothing$ konomisk og politisk kamp. Dette er en adskillesle, som må forståes som et resultat af den form, som det borgerlige samfund udvikler sig i. Konsekvensen af samfundets fordobling i samfund og stat er en fordobling af arbejdernes kamp i en økonomisk og en politisk kamp. Økonomisk kamp sættes ofte lig lønkamp, mens politisk kamp sættes lig kampen mod den kapitalistiske stat. Men denne distinktion er meget problematisk, fordi den overfører politikkens form i det borgerlige samfund til arbejderklassen. En politisk praksis, som bygger på distinktionen mellem økonomisk og politisk kamp, vil nødvendigvis udvikle sig i borgerlige former. Forestillingen om politik bliver vilkårlig, 
både når politik kun opfattes som et vedhæng til kapitalens bevægelse og når teoretikere og politikere mener, at kapitalen og staten manipulerer samfundet, som det proletariske parti så må modarbejde bevidst. Men man må langt snarere gå ud fra et begreb om kapitalens herredømme, som indeholder såvel økonomiske som politiske udtryksformer i det samfundsmæssige liv. Kapitalens herredømme er totalt og totalitært i den forstand, at det påvirker og determinerer hele samfundets struktur, hvorfor det strukturerer den økonomiske kamp som en politisk kamp og den politiske kamp som en $\varnothing$ konomisk. Derfor er det teoretisk og politisk forkert udelukkende at definere en politisk bevægelse som en bevægelse, der kæmper mod den borgerlige stat som den herskende klasses kollektive magt. Det er langt mere interessant at forstå de mange overgange fra økonomisk til politisk kamp og at forstå det politiske indhold i de økonomiske krav og den økonomiske kamp.

For det tredje er der den unge Marx' distinktion mellem menneske og borger eller homme og citoyen. Dette er en kategorial overførelse af samfundets fordobling i samfund og stat til det kapitalistiske individ, som fordobles på samme måde. Som borger agerer det kapitalistiske individ som agent for den kapitalistiske produktions love, men som menneske agerer det som et tilsyneladende frit og lige individ. Som borgere er der forskelle mellem den proletariske arbejder og kapitalisten, da deres økonomiske funktioner ikke blot er forskellige, men også modsigelsesfulde. Men som mennesker er de alle lige og frie, og alle forskelligheder udviskes. På det økonomiske plan får kapitalisten profit og arbejderen løn, men som mennesker får de alle en indtægt, som ikke er kvalitativt forskellig, kun kvantitativt. På denne måde opstår alle de illusioner, der er forbundet med det borgerlige samfund og den borgerlige ideologi. Denne er ikke kun en illusion, som er produceret forsætligt af nogle ideologiproducenter, men netop en illusion, som er indbygget i de samfundsmæssige formers struktur, hvori samfundet reproducerer sig selv. Samfundets fordobling reflekteres af menneskene, således at de konstituerer samfundet som borgere og staten som mennesker.

\section{III}

Forvirringen omkring disse distinktioner er en vigtig grund til forkerte opfattelser af det kapitalistiske samfund og den heraf følgende forkerte politik. Jeg vil nu fremføre et paradigma, som kan forklare dette problem.

Jeg har allerede været inde på, at sammensmeltningen af økonomi og politik, af bevægelseslove og magt, er karakteristisk for revisionen af Marx' analyse af det kapitalistiske samfund. Denne revision foregik i Tyskland efter 1890 i en periode med en relativt blomstrende kapitalisme. Den vigtigste repræsentant for den tyske revisionisme er Eduard Bernstein, som skriver: »Der findes ingen $\emptyset$ konomisk lov, som foreskriver, hvor mange af de producerede varer samfundets producerende lag skal kunne tilegne sig, og hvor mange de besiddende lag skal tilegne sig som tribut. Fordelingen af den samfundsmæssige rigdom har altid været et spørgsmål om magt og organisation.« 
De $\varnothing$ konomiske love, som Marx analyserede for at forstå den kapitalistiske produktionsmåde, substitueres på denne måde med magtkategorien. Magt er uafhængig af produktionsmådens love og er derfor ikke længere begrænset, men nu en kategori, i hvilken de økonomiske love er ophævet. Derfor vil en styrkelse af arbejdernes magt gøre dem i stand til at forbedre arbejdernes levestandard allerede inden for det kapitalistiske samfund. Kapitalens mulige reaktioner som dette samfunds subjekt reflekteres ikke længere eller reflekteres kun, som om det stammer fra magten.

Denne revision af den marxske teori har politiske konsekvenser, nemlig en amputering af det revolutionære indhold $\mathrm{i}$ analysen af kapitalismen. Nu behøver kapitalismen jo ikke længere afskaffes revolutionært for at kunne overskride grænserne for en forbedring af arbejdernes samfundsmæssige situation. Der findes ikke sådanne grænser eller hvis de findes, kan de i hvert fald fjernes gennem magten.

Revisionen bliver mere tydelig, hvis man ser på det argument, som Bernstein forklarer muligheden for lønstigninger med. Lønstigninger er mulige, fordi andre omkostningsfaktorer kan falde. Således undlader han at analysere den vigtige relation mellem arbejder og kapitalist eller løn og profit, og undersøger kun den overfladiske sammenhæng mellem lønomkostninger og andre omkostninger. Han skriver: »Forbedringer af arbejdsprocessen gør det muligt at formindske andelen af levende arbejde i det enkelte produkt, hvorfor en forhøjelse af prisen på menneskeligt arbejde kan blive kompenseret eller endda overkompenseret ved at spare på andre udgifter.« Merværdi og dens former, profit og rente, udelukkes i denne analyse. Lønnen analyseres kun med hensyn til dens sammenhæng med andre omkostnings- og priselementer. Hermed forsvinder antagonismen i den kapitalistiske produktionsproces i omkostningskalkulationens overfladeskær. I omkostningskalkulationen er alle omkostninger kvalitativt ens, og kun forskellige i kvantitativ forstand. Denne kvalitative lighed skjuler det faktum, at kapitalen omfatter kvalitativt forskellige ting, nemlig kapital og arbejde. Det er således denne kvalitative lighed, der gør Bernstein og andre revisionister i stand til at bringe forskellige ting på en klar dimension: magtdimensionen. Den kvalitative forskellighed synes kun at være en kvantitativ ulighed, som kan mildnes eller korrigeres ved en passende politik. Klassekampen tranformeres indholdsmæssigt til en kamp om indkomstfordeling.

Rudolf Hilferding når frem til samme konklusion. Det er meget interessant at summere hans argumentation, fordi den indeholder principielle metodologiske problemer, og fordi det kan vise, hvorledes metodologiske standpunkter får politiske konsekvenser. Hilferding søger en videnskabelig forståelse af de $\varnothing \mathrm{ko}-$ nomiske fænomener i senkapitalismens udvikling. Disse fænomener omfatter kapitalkoncentration, monopolisering eller kort sagt: finanskapitalens opstån. Han rejser herefter spørgsmålet om disse historiske manifestationer er særlige udtryk for den kapitalistiske udviklings almene love, eller om de er indikato- 
rer på en ny kvalitet hos kapitalismen. Hilferding rejser selv disse spørgsmål, men hans svar er ikke ensartede. På den ene side skriver han, at hvis man vil identificere forandringerne i erhvervscyklerne, så må man kunne forklare dem teoretisk for at være sikker på, at det ikke kun drejer sig om særlige cykler, som blot svarer til en bestemt fase i kapitalismen; at de altså ikke er tilfældige forandringer, men derimod tendenser, som er resultater af essensen i den kapitalistiske udvikling. Men på den anden side forkynder han, at finanskapitalen forandrer kapitalens karakter i almenhed. Kapital synes at være en ensartet magt, som regerer suverænt overfor samfundets livsproces. Er disse nye fænomener kun udtryk for den kapitalistiske produktionsmådes natur, eller er de nye fænomener udtryk for en ny kapitalisme - finans- eller monopolkapitalismen? Hilferding er ikke i stand til at give et klart svar på dette spørgsmål.

Teoretiske undersøgelser af den kapitalistiske udviklings natur fører ham til at forklare de nye fænomener i den kapitalistiske udvikling som udtryk for kapitalen i almenhed, mens hans betagelse over finanskapitalens nye fænomener, nemlig organisering af produktion og distribution og fremkomsten af store firmaer, fører ham til at tale om muligheden for at organisere kapitalismen og derfor om et nyt udviklingstrin, som er helt forskelligt fra den kapitalistiske konkurrences tidligere udviklingstrin. På denne måde får kapitalismen to forskellige essenser. Den ene er i overensstemmelse med den blinde konkurrences kapitalisme, og den anden korresponderer til monopolkapitalismen med muligheden for at organisere produktion, distribution og konsumtion. Mens krisens blinde lov tidligere regulerede kapitalernes aktioner, er det nu den forbundne bevidsthed hos de store trusters produktionsledere. Trustlederne fordeler produkter og produktion, og på denne måde regulerer og kontrollerer de den kapitalistiske udvikling. Og konsekvenserne: det er nu kun et spørgsmål om magt, om hvem der udøver kontrol og hvem produktionsresultatet tilhører. Man ser, at Hilferding ligesom Bernstein udvisker den kapitalistiske udviklings modsigelser ved at bringe alle modsigelsesfulde elementer på samme dimension - magt og styrke. Denne teori indeholder en meget underlig opfattelse af den kapitalistiske udvikling. På den ene side accepteres den kapitalistiske produktions bevægelseslove som helhed på den måde, Marx formulerede dem. Men i samme øjeblik monopolerne og finanskapitalen opstår, erklæres alle de bevægelseslove for den kapitalistiske produktion, som frembringer monopolet, ugyldige. Det ser ud som om kapitalismen ophører med at være kapitalisme, og især som om kapitalismens bevægelseslove ophører med at være love i de tilfælde, hvor monopoler opstår. Magtkategorien korresponderer med monopolerne, mens bevægelseslovene udelades.

Det er let at vise, at denne reduktion af de økonomiske modsigelser til magtog styrkedimensioner har meget stor politisk betydning. I sin meget berømte tale på det tyske socialdemokratis kongres i 1927 talte Hilferding om, at den organiserede kapitalisme er en realitet, der som helhed er forskellig fra den gamle konkurrencekapitalisme. Derfor må socialdemokratiet udvikle en ny taktik, der 
er i overensstemmelse med de nye fænomener i den organiserede kapitalisme. Det er et meget væsentligt punkt, når han fremhæver, at menneskene i dag lever i den periode af kapitalismen, hvor den frie konkurrence er forsvundet som blind regulator af markedet og kapitalisternes og arbejdernes handlinger. Nu er den kapitalistiske organisering og planlægning af $\varnothing$ konomien tværtimod blevet en realitet. »En virkelig organiseret kapitalisme betyder en principiel underordning af det kapitalistiske princip om fri konkurrence under det socialistiske princip om planlagt produktion. En planlagt og bevidst styret økonomi kan muligvis adlyde samfundets bevidste regulering, d.v.s. adlyde reguleringen fra den eneste samfundsmæssige organisation, som er bevidst og stærk nok: statens regulering."

I dette argument finder Hilferding ikke alene socialistiske principper i de kapitalistiske strukturer, men også, at staten kan overtages af den store masse af arbejdere. Hilferding konkluderer, at det kapitalistiske samfund underlægges den voksende indflydelse fra arbejderklassen mere og mere, og at arbejderklassens politiske princip om at bruge staten som regulerinsmiddel vinder. Men hvorledes skal man så påvirke staten til at handle i overensstemmelse med massen af arbejdere? Svaret er simpelt, og Hilferding giver det selv: »Skabelsen af statens intentioner er intet andet end kombinationen af de mange individers politiske viljer.«Argumentet er meget logisk. Kapitalismen organiserer sig selv, og ved at organisere sig skaber den allerede det socialistiske samfunds principper. Staten er ikke længere den herskende klasses stat, som må bekæmpes for at kunne opbygge et socialistisk samfund, men et apparat, som kan påvirkes af de individuelle vælgeres politiske viljer. Som følge af, at de mange individers store masse i det borgerlige samfund er arbejdere, er det deres opgave at bestemme statens vilje ved at stemme på et parti, som erklærer sig som arbejderparti. Derfor må det være en hovedopgave for socialdemokratiet at oplyse arbejdermassen, således at de stemmer socialdemokratisk. Socialdemokratiet vil være i stand til at give staten vilje i overensstemmelse med arbejdernes interesser.

Når de økonomiske love og modsigelser erstattes af magtkategorier, så må man som en konsekvens spørge om, hvorledes magt konstitueres, og Hilferding svarer, at den konstitueres ved at addere individernes - især arbejdernes - politiske viljer. I denne sammenhæng opfattes forholdet mellem politik og $\varnothing$ konomi således: Den politiske vilje, som er sammensat af de mange individuelle viljer, er den samfundsmæssige udviklings subjekt, mens den organiserede $\varnothing$ konomi hele tiden er dens objekt. Arbejderklassen må kæmpe for at erobre statens koncentrerede politiske vilje ved hjælp af stemmer og oplysning.

Statens rolle under kapitalismen reflekteres på en anden, men ikke mindre problematisk måde i teorierne om den statsmonopolistiske kapitalisme. Et argument er typisk for alle teorier om STAMOKAP, selv om de er forskellige på mange andre vigtige punkter. De fremhæver, at koncentrationen af kapitalproduktionen fører til en situation, hvor konkurrencen er elimineret, således at regulatoren af produktion og distribution også sættes ud af kraft. Følgen af konkurrencens 
forandring til monopolistisk konkurrence er også, at det er umuligt at regulere produktionen rationelt. D.v.s. at kapitalismen selv er ude af stand til at regulere produktion og distribution i sit sidste stadium. Derfor må der være en anden institution, som kan overtage de funktioner, som konkurrencen udfyldte tidligere.

Denne institution må være staten, som nu intervenerer systematisk i økonomien. Monopolet ødelægger konkurrencen som den kapitalistiske udviklings regulerende princip, men monopolet frembringer også en ny regulerende institution, staten, som indgår i en enhed med monopolet: monopol og stat smelter sammen i den statsmonopolistiske kapitalisme.

Monopolernes ophævelse af de $\varnothing$ konomiske love fremtvinger interventioner fra statens side, d.v.s. interventioner af den politiske magt - eller som en repræsentant for STAMOKAP-teorien, Peter Hess, udtrykker det: »Den $\emptyset$ konomiske og ikke- $\varnothing$ konomiske magt bliver eksekutor af de $\varnothing$ konomiske love på grund af det forhold, at værdilovens regulerende evne er sat ud af kraft ved koncentration, centralisering og monopolisering.« Monopol, magt og stat er således de tre kategorier, som STAMOKAP-teorierne bygger på. Denne anvendelse af magtkategorien fører tilbage til det eksempel, som er anført i begyndelsen. Som en relation mellem magt og styring er det monopolets mål at tilegne sig fremmed kapital, fremmed profit, fremmed ejendom og derfor fremmed arbejde. Det er klart, at denne tilegnelse af revenu ikke alene kommer fra en direkte udbytning af arbejderne, men netop implicerer mere end det. Derfor erstattes profitkategorien med tributkategorien. Således ser man her - på et andet plan at repræsentanter for STAMOKAP-teorierne drager en konklusion, der ligner Hilferdings. Men nu er det ikke længere klart, hvorledes monopoltributterne produceres og fordeles, og det er heller ikke klart, hvilke grænser de er underlagt og hvilke samfundsmæssige modsigelser og konflikter, der følger af denne udplyndring af hele samfundet. I modsætning til teorien om monopoltribut og denne kategori, følger profitbegrebet visse love med hensyn til profittens dannelse og udvikling, som er udtrykt i teorien om dannelsen af en gennemsnitlig profitrate og den gennemsnitlige profitrates tendens til fald.

Før vi kan gå ind på en diskussion af statens rolle under monopolkapitalismen, må vi betragte relationen mellem monopol og bevægelseslove. Hvis der også er bevægelseslove under monopolistiske betingelser, så må der være grænser for den statsmonopolistiske intervention, og omvendt: hvis der ikke findes bevægelseslove, vil det være absurd at tale om grænser for statens handlinger under STAMOKAP.

\section{IV}

Vi skal først skelne mellem to aspekter ved det kapitalistiske samfunds bevægelseslove. Der er dels de væsentlige bevægelseslove for produktionsrelationerne og dels bevægelseslovenes gennemslagsformer i den samfundsmæssige realitet. Konkurrencen betragtes som bevægelseslovenes gennemslagsform, og 
hvis konkurrencen afskaffes, vil bevægelseslovenes gennemslag blive forhalet og forandret.

Vi skal nu betragte et særtræk ved den marxske teori. I alle de tilfælde, hvor Marx taler om bevægelseslove, antager han, at disse bevægelseslove omfatter den samfundsmæssige totalkapital og ikke ubetinget enhver enkeltkapital. Men på den anden siden eksisterer denne samfundsmæssige totalkapital i form af mange enkeltkapitaler. Enkeltkapitalerne, og ikke den samfundsmæssige totalkapital, er agenterne i samfundet. Man må således forestille sig, at de mange enkeltkapitalers handlinger konstituerer det, som kan kaldes den samfundsmæssige totalkapital, som bevægelseslovene korresponderer med. Denne relation mellem enkeltkapital og samfundsmæssig totalkapital konstituerer det, som så ofte kaldes den kapitalistiske udviklings anarki eller spontanitet. Ingen enkeltkapital kender det nøjagtige resultat af sine handlinger. Men gennem deres handlinger, konstituerer enkeltkapitalerne den samfundsmæssige totalkapital og bestemmer kapitalismens udviklingsmåde. Heraf følger, at alle enkeltkapitaler er brøkdele af den samfundsmæssige totalkapital. Det stærkeste udtryk for denne relation er, at enhver enkeltkapital ikke får mere end den gennemsnitlige profitrate, d.v.s. at den får sin profitandel af den totale producerede merværdi i forhold til sin egen størrelse. Dette er meget vigtigt, fordi det betyder, at hvis nogle enkeltkapitaler er i stand til at få mere profit end andre, så er de i stand til at unddrage sig de betingelser, som sættes gennem bevægelseslovene for den samfundsmæssige totalkapital. Nu kan man indvende, at det i den kapitalistiske realitet er helt normalt, at nogle enkeltkapitaler får mere profit end andre og omvendt, samt at der ikke findes en gennemsnitsprofitrate for alle enkeltkapitaler. Og denne indvending er helt korrekt. Dannelsen af gennemsnitsprofitraten kan nemlig kun forstås som en tendens, ikke som en realitet på ethvert tidspunkt. Men denne tendens må dog realiseres, i hvert fald indenfor den industrielle cyklus. Hvis der findes enkeltkapitaler, som er i stand til at unddrage sig den tendentielle dannelse af gennemsnitsprofitraten for en meget langt periode, er de ikke længere elementer i den samfundsmæssige totalkapital. Denne antagelse forekommer mig at give den $\varnothing$ konomiske betydning af argumentet om monopolet som en relation mellem magt og styring eller den ikke- $\varnothing$ konomiske magt, som den monopolistiske konkurrence bygger på. Hvis monopolspørgsmålet forstås på denne måde, er monopolet kun et spørgsmål om tid: hvor længe er en enkeltkapital i stand til at unddrage sig tendenser til dannelse af en gennemsnitsprofitrate, samt omvendt hvor længe varer det før konkurrencen har bragt monopolprofitten på gennemsnitsprofitratens niveau?

Det vil selvfølgelig være absurd at benægte, at der er forskelle i enkeltkapitalernes profitrater, men det vil være lige så absurd at gå ud fra en antagelse om, at der altid må være et hieraki af profitrater. Dette ville nemlig være i modstrid med opfattelsen af kapital som et samfundsmæssigt forhold, som må forstås både kvalitativt og kvantitativt. Kvalitativt omfatter kapital forholdet mellem kapital 
og arbejde og derfor kapitalens udbytning af arbejderklassen. Hele den profit, som fordeles mellem enkeltkapitalerne, er skabt af arbejderklassen i et land, henholdsvis arbejderklassen i international forstand. Dette kvalitative forhold mellem kapital og arbejde som en helhed, fremstår kvantitativt for hver enkeltkapital, fordi profitraten er et kvantitativt mål, hvormed kapitalen måler sin realisering som vækst i dens størrelse (værdiens selvvalorisering, »selbstverwertung des Wertes «). Kapitalen kan kun eksistere videre som en kvalitativ relation, hvis den kvantitativt udtrykte profitrate er stor nok. Dette betyder, at den kvantitative vækst i enkeltkapitalens størrelse er en betingelse for, at kapitalen kan opretholde sig som en kvalitativ relation. Hvis der i en længere periode eksisterer enkeltkapitaler med en meget lav profitrate og andre enkeltkapitaler med en meget høj profitrate (monopoler) vil det nødvendigvis betyde, at kapitalforholdet som et kvalitativt forhold vil blive berørt af disse kvantitative forskelle. Denne dialektik mellem kvantitet og kvalitet under monopolistiske betingelser har endnu en konsekvens. Hver enkeltkapitals mål er at opnå en så stor profit som muligt, hvilket kvantitativt er i modsætning til enhver anden enkeltkapitals mål. Kapitalens realisering er altid begrænset af den udbyttelige arbejdskrafts størrelse, af arbejdsdagens længde, af arbejdsintensiteten, af lønforhøjelser og sidst, men ikke mindst, af arbejdets produktivkraft. Derfor vil konkurrencen også forekomme selv under monopolistiske betingelser. Enhver enkeltkapital konkurrerer med de andre om den udbyttelige arbejdskraft, om forøgelser af arbejdsproduktiviteten o. s. v. I denne forstand er muligheden for en kvantitativ profitforøgelse begrænset af det kvalitative forhold mellem kapital og arbejde. Man kan altså konkludere, at konkurrencen ikke alene regulerer enkeltkapitalernes indbyrdes forhold, men også forholdet mellem kapital og arbejde. Når man teoretisk taler om modificeringen af værdiloven eller endda dens ophævelse under monopol- og statsmonopolkapitalisme, proklamerer man følgelig også ophævelsen af kapitalismen som samfundsmæssigt system. Vi har allerede set, at Hilferding drog denne konklusion ret logisk ved at betragte den organiserede kapitalisme som et helt nyt system i forhold til den gamle kapitalisme med en fri eller ubegrænset konkurrence. Hvis værdiloven er ophævet eller blot modificeret, må der selvfølgelig være andre love og grænser for statsinterventionerne, end det ville være tilfældet, hvis der fandtes bevægelseslove for den kapitalistiske udvikling.

V

Hvorledes forholder den frie konkurrence sig til den monopolistiske konkurrence.

Som regel bestemmes monopolet ved at være i stand til at opnå en monopolprofit. Den frie konkurrence fører derimod til, at de enkelte profitrater udlignes til en samfundsmæssig gennemsnitsprofitrate. I monopolet findes denne tendens ikke. Denne opfattelse er fælles for såvel borgerlige som marxistiske teoretikere. Man kan citere Heiniger/Hess: »Den monopolistiske konkurrence hviler på anvendelse 
af $\varnothing$ konomisk og ikke-økonomisk magt og vold med den hensigt at producere og realisere monopolprofit - dette er den afgørende forskel fra den førmonopolistiske frie konkurrence. I og med at monopolet ophæver den frie konkurrence, undergraver det også den mekanisme, som hviler på gennemsnitsprofitter - den mekanisme, der fik den enkelte producent til spontant at handle i overensstemmelse med de $\varnothing$ konomiske love og som medførte en fordeling af profitten i overensstemmelse med kapitalstørrelsen. I stedet for den frie konkurrence og ved siden af den træder netop monopolernes $\varnothing$ konomiske magt og vold. Denne træder nu overfor producenterne, og den gør den kapitalistiske produktionsmådes indre lovmæssigheder gældende overfor producenterne som tvangslove til handling. Den $\emptyset$ konomiske og ikkeøkonomiske magt og vold bliver de økonomiske lovmæssigheders 'eksekutor'. Man behøver vel næppe at betone, at dette intet har at gøre med absolutte monopolvilkår i det $\varnothing$ konomiske område... « (s. 34 i Imp. der BRD).

Men man må selvfølgelig spørge om I) hvorfra stammer monopolprofitterne og II) om og hvordan de indgår i gennemsnitsprofitratens udligningsproces.

Mht. første spørgsmål om hvorfra monopolprofitterne stammer, er der principielt 4 muligheder:

1) Monopolistiske profitter er ene og alene ekstraprofitter, fremkommet ved det forhold, at de monopolistisk frembragte eller producerede varers individuelle værdi ligger under deres samfundsmæssige værdi eller under branchens markedsværdi, hvorfor der kan opnås en ekstraprofit.

2) Monopolprofitterne stammer fra den ikke-monopoliserede sektor og er kun overførte vardidele fra denne sektor.

3) Monopolprofitterne stammer fra en overgennemsnitlig udbytning af arbejderne, uanset om denne udbytnings form er sænkning af arbejdskraftens pris under dens værdi eller en overgennemsnitlig arbejdsintensitet eller arbejdstid. Monopolprofitterne kunne da kaldes 'løntyveri'.

4) Monopolprofitterne kan også forklares ved at de eksisterende kapitaler omfordeles til fordel for monopolerne, d. v. s. at den eksisterende kapitalstok i en periode går over til monopolerne, således at monopolprofitterne ikke er begrænsede af den samlede merværdimasse.

Man må vide hvorfra monopolprofitterne stammer, eftersom svaret på dette spørgsmål også indeholder svaret på det andet spørgsmål, altså om en totaløkonomisk gennemsnitsprofitrate også kan udvikles under monopolbetingelser. Her må vi dog minde om to tilsyneladende simple sammenhænge.

A). I gennemsnitsbegrebet og i gennemsnitsprofitraten er det samfundsmæssige moment indeholdt, det moment, som alle enkeltkapitler og kapitalen som totalkapital er underlagt. Trods de individuelle forskellige produktionsbetingelser frembringer kapitalen både gennemsnitlige udbytningsbetingelser, som udvikles som en gennemsnitlig merværdirate (det er derfor ikke kun en forsimplende antagelse i Kapitalens 1. bog, hvor Marx går ud fra en fælles gennemsnitlig merværdirate på 100) og samtidig udtrykkes i gennemsnitsprofitraten 
enhver enkeltkapitals deltagelse i den merværdimasse, der er frembragt af den totale samfundsmæssige arbejderklasse, i overensstemmelse med sin størrelse.

Hvis man nu går ud fra, at der findes to gennemsnitsprofitrater - den normale og den monopolistiske - må man som konsekvens heraf også gå ud fra, at der under monopolistiske produktionsbetingelser findes to kapitalistiske »subsamfund « indenfor det kapitalistiske samfund: et, hvor loven om udligning af ekstraprofitter gælder, og et, hvor loven om gennemsnitsprofitraten gælder uden resp. med fradrag for ekstraprofitterne. Eller med andre ord: en del af samfundet, hvor loven om udligning ikke kan virke og en anden, hvor den kan virke.

Foreløbig betyder dette dog ikke andet end, at lovmæssighederne for kapitalen i almenhed vil gælde for hele det kapitalistiske samfund, mens den form, som disse lovmæssigheder sætter sig igennem i, kan være forskellige og endda modstridende.

Formidlingen mellem disse to samfund indenfor et og samme kapitalistiske samfund sker ved, at der foregår værdioverførelser fra den ikke-monopoliserede sektor til den monopoliserede, og herved findes grænserne for begge samfunds totale profitmasse i størrelsen af den totale af arbejderklassen frembragte merværdimasse. Alligevel er en sådan antagelse om eksistensen af to forskellige gennemslagsformer for de kapitalistiske lovmæssigheder i et land i en bestemt tidsepoke en vidtrækkende opgivelse af værdiloven og dermed også en opgivelse af den marxske teori. Dette skyldes, at værdiloven omfatter både den kapitalistiske produktions immanente nødvendigheder og gennemslagsformen for disse immanente nødvendigheder. Man kan ikke se det ene uden det andet.

$» \mathrm{Da}$ nu varernes totalværdi bestemmer totalmerværdien, mens denne så igen bestemmer gennemsnitsprofittens højde og dermed den almene profitrate - som almen lov, d. v. s. som det, der behersker svingningerne - så regulerer værdiloven produktionspriserne.«(3:1, s. 233). Alle andre antagelser om ikke eksisterende gennemsnitsprofitrater overser vanskelighederne ved så at skulle forklare, hvilke udligningslove, der nu gælder.

$B$ ). Antagelsen om de to profitrater resp. om en gennemsnitsprofitrate og mange individuelle monopolprofitrater kan implicere, at den gennemsnitsprofitrate som Marx udledte for den »frie« konkurrence, skulle eksistere som sådan »ansich« på ethvert tidspunkt.

Men gennemsnitsprofitraten er langt snarere på enhvert tidspunkt de mange enkeltkapitalers gravitationscentrum. Den er aldrig en virkelig gennemsnitsprofitrate, men en tendens, som alle kapitaler bevæger sig hen mod.

»I den kapitalistiske produktion er det i det hele taget altid sådan, at den almene lov kun gør sig gældende som herskende tendens på en yderst kompliceret og tilnærmet måde, som et aldrig fastslået gennemsnit af stadige svingninger.«: $3: 1,209)$.

Set i dette lys er forskelligheden i den monopoliserede og ikke-monopoliserede sektors profitrater ikke noget særligt i forhold til den »frie« konkurrence. 
Det, som egentlig skulle begrundes, er varigheden af de enkelte kapitalers mulighed for at opnå ekstraprofitter uden, at muligheden forsvinder igen.

Fritz Behrens har set denne sammenhæng: »Da kapitalernes konkurrence om investeringssfærer ikke er ophævet, men kun hæmmet, følger det også, at disse monopolprofitrater også har en tendens til at udlignes; men denne tendens virkeliggфres nu ikke langere som $i$ den førmonopolistiske kapitalisme $i$ løbet af en enkelt cyklus. «(Behrens i »Bemerkungen zur Profitrate im monopolistischen Kapitalismus, « i: Wirtschaftswissenschaft, 5. Jahrg. 1957 s. 256).

Det ville ikke føje noget nyt til Marx' fremstilling af gennemsnitsprofitratens udvikling, men nok være en modifikation, hvis man kunne begrunde, at udviklingen af ekstra-profitter ikke ubetinget må forekomme inden for en og samme cyklus, men kan foregå gennem flere cykler, betinget af statens funktioner og verdensmarkedssammenhængen.

Men lad os nu vende tilbage til de fire fundamentale muligheder for monopolprofittens opståen.

Ad 1: Ekstraprofit pga. forskellen mellem markedsværdi og individuel værdi.

Kapitalernes indbyrdes relationer indenfor en branche fører via konkurrencen til markedsværdiens opstån. En given vares gennemsnitlige produktionsbetingelser bestemmer dens samfundsmæssige værdi (markedsværdien), som de enkelte vareproducenters individuelle produktionsværdier kan afvige fra. De gennemsnitlige produktionsbetingelser skal forstås som de typiske, altså den store masses produktionsbetingelser, og ikke som en fiktiv regnestørrelse med et fiktivt gennemsnit af indbyrdes afvigende produktionsprocesser. Hvis enkelte kapitaler, producerer under de samfundsmæssigt gennemsnitlige produktionsomkostninger på grund af en bedre teknologi, d. v. s. hvis deres kostpris er lavere end den samfundsmæssige, så vil de opnåen tillægsprofit ud over den normale, en ekstraprofit. Denne ekstraprofit fremkommer ikke i kraft af værdioverførsel fra andre brancher eller kapitaler, men udelukkende på grund af forskellen mellem individuel og samfundsmæssig værdi.

Indenfor en branche findes der derfor på ethvert givet tidspunkt forskelle i de profitrater, som de enkelte kapitaler opnår, forskelle, som dog altid opløses gennem konkurrencen, hvor de også genskabes.

Den bedre produktionsteknologi, som gør det muligt for en enkelt kapital at sænke den individuelle vares værdi under dens markedsværdi, giver denne enkeltkapital en midlertidig monopolstilling i og med at den muliggør opnåelsen af en monopolprofit i form af ekstraprofit. De behøver ikke nødvendigvis at være de største kapitaler, der får denne ekstraprofit, men kan i vidt omfang også være mindre kapitaler, der udfører eksperimentel produktion med avanceret produktionsteknologi. Dette forhold må tages med i betragtning for ikke at falde for den gængse misforståelse, at monopolerne er lig store koncerner og ikke-monopoler er lig mindre og mellemstore foretagender. Det kan omvendt endda være tilfældet, at de store foretagender ikke er tvunget til at indføre en 
ny teknologi for at opnå ekstraprofitter, fordi de er store nok til at udnytte deres finanskraft så meget, at de helt kan undgå de ricisi, der er forbundet med indfrielsen af den nye produktionsteknologi.

Spørgsmålet bliver nu, om ekstraprofitter, der er opstået som en følge af forskellen mellem individuel værdi og markedsværdi, kan være vedvarende - altså udgøre en permanent monopolprofit ud over den almindelige profit. Det kan den kun hvis følgende to betingelser er opfyldt:

a). Hvis det kan lykkes for den kapital, der er i stand til at opnå en ekstraprofit på denne måde, at fastholde sit teknologiske forspring. Dette kan ske ved at enhver teknologisk udvikling hos de andre enkeltkapitaler i samme branche blokeres.

b). Eller hvis det teknologiske forspring opretholdes ved at den teknologiske fornyelseshastighed er mindst lige så stor som hos konkurrenterne - de efterfølgende kapitaler, der producerer varer til samfundsmæssig værdi.

Tilfælde a) ville implicere en standsning i den teknologiske udvikling og en cementering af et givet teknologisk niveau.

Tilfælde b) ville implicere det modsatte, nemlig en progressiv forøgelse af den teknologiske fornyelse.

Begge tendenser er således virksomme, og netop herfra stammer de store koncerners vaklende og modsigelsesfulde teknologipolitik: dels opretholdelse af meget store forsknings- og udviklingsafdelinger, både absolut og relativt, som der anvendes meget kapital til. Herfra kommer der nye produkter, ny teknologi og nye produktionsmetoder m.v. Dels også en forsegling af den teknologiske erkendelse gennem patentering, fabrikationshemmeligheder o.s.v. for at forhindre andre kapitaler $i$ at få viden om ekstraprofittens årsag i en specifik produktionsteknologi. Herved hindres den nye teknologis udbredelse, og udligningen mellem varernes samfundsmæssige værdi og de mest avanceret producerede varers individuelle værdi vanskeliggøres. Men teknologiens udbredelse og hermed ekstraprofitternes afskaffelse kan dog ikke forhindres helt, eftersom det ikke kun er kapitalerne indenfor en og samme branche, der indgår i udligningsbevægelsen. Den foregår jo netop over produktionsprisen, d.v.s. over konkurrencen mellem brancherne. D.v.s. at de kapitaler, der er udlagt i andre brancher med en lavere profitrate end den avancerede kapital, som vi betragter her, også indgår i denne formidlingsbevægelse.

Sammenfattende kan vi altså sige, at her viser det sig, at de udligningsbevægelser, som Marx har formuleret, fortsat er virksomme, men nu nok over et længere tidsrum end under den »frie« konkurrence.

ad 2) Profitoverførsel fra den ikke-monopoliserede sektor. Enkeltkapitaler har kun andel i den af arbejderklassen producerede merværdimasse som bestanddele af den samfundsmæssige totalkapital, uanset hvor store de måtte være. Men da enkeltkapitalernes produktionsbetingelser er forskellige, især med hensyn til organisk sammensætning og omslagstid, ville den opnåede pro- 
fitrate være forskellig, selv under antagelse af samme merværdirate, hvis der ikke forekom værdioverførsler mellem kapitaler i forskellige brancher. Dette betyder, at der allerede i gennemsnitsprofitratens udligningsproces $n \phi d v e n d i g$ vis må finde vardioverførsler sted under den frie konkurrences betingelser. Ellers ville der nemlig slet ikke findes nogen gennemsnitsprofitrate.

Når man således taler om monopolernes ekstraprofit, opstået gennem værdioverførsel fra den ikke-monopoliserede sektor, må det altså være merværdioverførsler, som ved denne overførsel medvirker til en udligning af profitraten, altså til gennemsnitsprofitratens opståen. For den ikke-monopoliserede sektor betyder dette, at dens gennemsnitlige profitrate må være lavere end den ville være, hvis den monopoliserede sektor ikke fik en vedvarende monopolistisk ekstraprofit.

Spørgsmålet bliver så, om monopolerne kan gøre disse profitrateforskelle vedvarende? Når vi ser bort fra verdensmarkedskonkurrencen, kan det ikke lade sig gøre af følgende grunde:

a) Hvis monopolernes profitrate ligger betydeligt over de ikke-monopoliserede kapitalers profitrate, vil udligningsprocessen virke over kort eller lang tid derved, at de kapitaler, som har en langt lavere profitrate, bevæger sig ind i den monopoliserede sektor for at akkumulere her. »Kapitalen trækker sig imidlertid ud af en sfære med lavere profitrate og kaster sig over andre, der afkaster højere profit. Som følge af denne bestandige af- og tilgang, kort sagt, som følge af hvorledes kapitalen fordeler sig på de forskellige sfærer, alt efter om profitraten falder det ene sted og stiger det andet, fremkalder den et sådant forhold mellem udbud og efterspørgsel, at gennemsnitsprofitten indenfor de forskellige produktionsfærer bliver den samme og værdierne derfor omdannes til produktionspriser.« (3:1, s. 253-4) Monopolerne kan måske nok spærre for denne udligningsproces en vis tid, men på langt sigt vil det ikke kunne lykkes hvis profitforskellen er store nok til at lokke mængder af akkumulationsduelig kapital til disse højprofitable sektorer, formidlet gennem finanskapitalen.

b) Lad os nu betragte processen fra den anden side: Også i monopolkapitalismen virker konkurrencen på den måde, at kapitaler koncentreres, fusioneres og centraliseres. Denne tendens er egenartet for den kapitalistiske akkumulation, hvilket Marx har vist i Kapitalens bind 1 kap 23. Men når koncentrationsog centraliseringsprocessen griber ind over den ikkemonopoliserede sektor, således at små kapitaler sluges af monopolerne, må deres lavere profitrate også udtrykke sig i en forringelse af monopolernes profitrate, for så vidt som monopolernes ekstraprofitter fremkommer gennem værdioverførsel fra den ikkemonopoliserede sektor. I det ekstreme tilfælde vil monopolernes ekstraprofitter forsvinde, når hele den ikke-monopoliserede sektor er opslugt af monopolerne. Denne tendens er også virksom, hvilket fremgår af, at monopolerne ikke kan akkumulere deres profitmasse inden for deres egen branche, hvorfor de har meget store mængder kapital, som søger investeringssfærer. De kan ikke akkumulere deres profitmasse indenfor deres egen branche af hensyn til oprethol- 
delsen af deres monopolstilling d.v.s. for ikke at true deres monopolprofitter og monopolpriser.

Når man påstår, at tendensen til koncentration og centralisering virker samtidig med muligheden for monopolistiske ekstraprofitter gennem værdioverførsel, bevæger man sig ind i en immanent modsigelse, som kun kan løses ved at man ikke længere kan benægte, at udlignigstendenserne fører til dannelsen af en totalsamfundsmæssig gennemsnitsprofitrate.

Her er det også klart, at udligningstendenserne virker over længere tidsperioder end under den »frie« konkurrence.

ad 3) Monopolekstraprofitter som følge af sænkning af prisen på varen arbejdskraft.

Forsøget på at sænke arbejdskraftens pris under dens værdi er ikke særegent for monopolkapitalismen. Det har netop kendetegnet den »frie « konkurrences epoke, hvilket arbejderklassens historie tydeligt viser. Metoderne til denne sænkning er lige så gamle som selve den kapitalistiske udbytning: løntryk, for$\emptyset$ gelse af arbejdstiden uden lønstigning, større arbejdsintensitet, salg af nødvendige konsumvarer til en pris over deres værdi, hvorved reallønnen trykkes nedad o.s.v. Lykkes disse forsøg på sænkning af arbejdskraftens pris, bliver resultatet en forøgelse af merværdiraten for alle kapitaler, og ikke en forøgelse af monopolprofitten for den monopoliserede sektor. Og her kommer vi til det kritiske punkt i monopolprofitteorien. Man går ikke alene ud fra, at gennemsnitsprofitraten ikke længere er gyldig, hvorfor der sker en opdeling i en monopolprofitrate og en ikke-monopolprofitrate, men man går endda også ud fra, at de gennemsnitlige udbytningsbetingelser $\mathrm{i}$ et givet nationalt samfund ikke længere gælder, d.v.s. at man går ud fra, at monopolkapitalens mervaerdirate er større end merværdiraten i den ikke-monopoliserede sektor. Denne antagelse er under alle omstændigheder i modstrid med lønarbejderens frihed til selv at vælge sin arbejdsplads, hvilket er konstituerende for selve kapitalforholdet. Kun hvis arbejdskraftens mobilitet enten ikke er frembragt endnu eller indskrænket af andre grunde, kan man gå ud fra, at monopolprofitterne stammer fra værdi- eller prissænkning på varen arbejdskraft.

ad 4) Monopolprofitter gennem nyfordeling af de eksisterende kapitaler til monopolernes fordel.

Denne form for overførsel vedrører selve kapitalens substans og kan netop af denne grund kun være forbigående. Men alligevel må den tillægges stor betydning. Den historiske erfaring har vist, at ekspropriationen af små og mellemstore kapitaler til fordel for monopolerne rent faktisk har foregået og $\mathrm{i}$ begge verdenskrige foregår især i perioder med stor inflation, frem for alt nu med den gallopperende inflation. Her ligger en kilde til monopolprofit, som dog kun springer, når andre betingelser også er opfyldt, d.v.s. især når staten tager monopolernes parti i denne proces og først rigtig kaster ved på inflationens bål i form af optagelse af statslån for så at ekspropriere den lille kapital eller sparerne. 


\section{Foreløbig sammenfatning}

Der findes ingen $\emptyset$ konomisk mekanisme, der sørger for, at monopolerne vedvarende kan opnå en ekstraprofit i forhold til den ikke-monopoliserede sektor.

De to første former tillod kun midlertidige monopolstillinger, omend monopolstillingens varighed er større i den udviklede kapitalisme end i den svagt udviklede.

Den tredje form for ekstraprofit tilfalder alle kapitaler, monopolform eller ej.

Den fjerde form muliggør ganske vist monopolekstraprofit, men kun midlertidig, eftersom den - hvis den forudsættes at fortsætte fremover - vil ødelægge $\varnothing$ konomiens substans på langt sigt, hvorfor de således opnåede monopolprofitter ikke vil kunne akkumuleres umiddelbart. De vil kun kunne akkumuleres under monopolkapitalens ejendomstitel, ikke i dens reale udbytningsproces.

Dermed har vi også givet - implicit - et svar på det andet spørgsmål, nemlig om monopolprofitterne indgår i udligningsprocessen? Fred Oelssner anfører fire former for stillingtagen til dette spørgsmål, som skal anføres her (i: Probleme der politschen Ökonomie, Bd. 3, Berlin 1960, s. 70ff.).

Den første gruppe mener, at loven om gennemsnitsprofitraten fortsat virker. Dens gennemslag er ganske vist vanskeliggjort, men i sidste ende realiseres en ensartet samfundsmæssig gennemsnitsprofitrate.

Den anden gruppe taler om to forskellige profitrater, nemlig en for den monopoliserede og en for den ikke-monopoliserede del af økonomien.

Den tredje gruppe taler om, at gennemsnitsprofitraten kun kan udvikles for den ikke-monopoliserede del af økonomien, mens den ikke kan opstå for den monopoliserede sketor.

Den fjerde gruppe afviser, at man overhovedet kan tale om gennemsnitsprofitrate under monopolkapitalismen, eftersom den modsiger monopolkapitalismens væsen.

Oellsner slutter sig selv til den 3. gruppe med følgende begrundelse: »Tesen om monopolgennemsnitsprofitrate lader sig med andre ord ikke fastholde teoretisk, fordi monopolernes $\emptyset$ konomiske magt er meget forskellig og fordi, som Mendelson rigtigt anfører, der ikke findes eller kan findes 'en lov for en ligelig fordeling mellem alle monopoler af Gründergevinst, differentialrente og profit som følge af svig med statsejendom ved udplyndring af kolonierne o.s.v.' Men selv når man ser bort fra disse faktorer og kun betragter varemonopolet og monopolprisen for varer, kan der alligevel ikke findes en gennemsnitsprofitrate for monopolprofitten, fordi den gamle frie konkurrence ikke hersker blandt de monopolistiske industri- og handelsvirksomheder, men derimod monopolkonkurrencen. Til forskel fra den frie konkurrence er den monopolistiske konkurrence i høj grad ujævn.« (Behrens, s. 76).

Alt ialt er det kun den første gruppe med den anførte modifikation der kan begrundes i den marxske teori. Netop modifikationen - at gennemsnitsprofit- 
ratens udligning først sker over flere lange cykler - vil sikkert vise sig at være meget vigtig ved analysen af mere afgrænsede historiske perioder.

\section{VI}

Vi skal nu diskutere statsaktiviteterne og forsøge at påvise grænserne for statsaktiviteter under monopolistiske forhold. Der er fire gode grunde til antagelsen om begrænsede statsaktiviteter:

1) statsaktiviteterne betales ud af det producerede revenu, og finansielle midler er derfor altid bundet til den proces, der frembringer revenuet, d.v.s. til kapitalens akkumulationsproces.

2) statsinterventionens instrumenter stammer fra den kapitalistiske $\varnothing$ konomis struktur og må derfor være lige så selvmodsigende som denne økonomi. Statshandlingernes suverænitet ødelægges af, at instrumenterne er for begrænsede til at styre samfundsmæssige processer.

3) Betydningen af samfundets klassestruktur, omfanget af særlige traditioner, den herskende klasses såkaldte politiske kultur, mm. Alle disse mere sociologiske betingelser for statsindblanding er forhindringer for staten, når den skal gribe ind på den måde, der er nødvendig.

4) Statens karakter af nationalstat betyder, at statsinterventioner kan påvirkes af verdensmarkedet, af andre nationalstaters modsat rettede politik og af kapital- og varecirkulationens gensidige afhængighed.

Disse fire årsager må dog forklares mere udførlig.

Man kunne sige, at statsinterventionens grænser skyldes den såkaldte »finanskrise «, som er et strukturelt karakteristikon ved den moderne kapitalisme. Empiriske forhold alene forklarer intet. Af den grund må vi undersøge to forhold som er relevante indenfor rammerne af denne diskussion. Det ene forhold er statens finansielle kilder, og det andet drejer sig om statens anvendelse af finanserne.

I denne sammenhæng støder vi på et ret alvorligt problem. På det kapitalistiske samfunds overflade er enhver ligeså lige og fri som sin nabo, og det fremtræder derfor som om alle betaler til de offentlige indtægter ved at betale skatter og ved at bære en del af nationalgælden. Da enhver borger får et revenu, som kun varierer kvantitativt, trækker staten sine indtægter fra individernes. Det ser således ud som om alle behandles ens også m.h.t. skattebetaling. Men på den anden side ved vi, at det kun er på overfladen, at det kapitalistiske samfund er dannet af lige individer, mens det $\mathrm{i}$ virkeligheden er et samfund delt $\mathrm{i}$ to klasser, kapitalister og arbejdere. Staten udskriver ganske vist sine skatter fra de skatte-betalende undersåtter, og i denne sammenhæng forsvinder distinktionen mellem arbejder og kapitalist. Men det forhold, at disse skatter er pålagt særskilte klasser og at de er fradrag fra særlige indtægter - løn på den ene side og profit på den anden - gør, at disse skatter har forskellige $\varnothing$ konomiske følger, afhængig af om de er trukket fra løn eller profit.

Skat på løn er naturligvis begrænset af de fornødenheder der medgår til arbejdskraftens reproduktion, som igen er afhængig af fysiske, historiske og kulturelle 
betingelser samt af arbejderklassens politiske styrke. De kan derfor ikke overskride en vis, historisk given størrelse. Men denne bestemmelse forbliver upræcis så længe det ikke er forklaret, hvad arbejdernes indtægter og statens udgifter bruges til. Dette skyldes, at alle de statsudgifter, der kun er en omfordeling, forbliver en del af arbejderklassens indtægter og arbejdskraftens reproduktionsmidler. I denne situation er det lige meget om arbejdskraftens reproduktion sker gennem individuel løn-indkomst eller gennem statsudgifter, kaldet »kollektiv indkomst«, til uddannelse af arbejdskraft, sundhedstjeneste, sociale sikringssystemer, o.s.v. Det betyder intet, om disse fornødenheder til arbejdskraftens reproduktion udfyldes af individuel løn eller af statsudgifter der stammer fra skat på individuel løn. Dette er udelukkende et problem om at fordele risikoen mellem arbejderne.

Ved diskussionen af dette problem er det blevet tydeligt, at skatters $\varnothing$ konomiske følger på ingen måde er uafhængig af den måde, de er fremkommet på. Men samtidig bliver det indlysende, at en forøgelse af enten lønnen eller statens udgifter til arbejdskraftens reproduktion resulterer - alt andet lige - i en vækst i arbejdskraftens værdi med den følge, at merværdien formindskes. For vores problem om grænser for statsfinansiering får det følgende konsekvens:

Effekten på merværdien af de stigende udgifter til reproduktion af arbejdskraft hæmmer deres vækst udover et vist punkt.

Lad os nu undersøge et andet eksempel. Statsudgifter anvendes til »produktionens generelle forudsætninger«, sædvanligvis kaldt infrastruktur. Som produktionens forudsætninger er de nødvendige for hver enkelt kapitals produktionsproces. Dette gælder for veje, jernbaner, luftfart, vandforsyning samt kompensation for miljøkriser, dræning og et fungerende kommunikationssystem (post, telegraf o.s.v.). I disse tilfælde er statsinterventionens selvmodsigende karakter åbenlys. Disse udgifter er på den ene side nødvendige i bogstavelig forstand udfyldende under hensyn til den materielle side af værdien og kapitalens produktionsproces. Disse udgifter må på den anden side pålægges kapitalistklassen som helhed under den antagelse, at arbejderklassen ikke modtager mere end det, som er nødvendigt for reproduktion af dens arbejdskraft.

Det er således tydeligt, at udlæg til infrastruktur er fradrag i merværdien. Under den realistiske antagelse at kapitalistklassens komsumtion er ret konstant, er der tale om fradrag i den del af profitten, der var beregnet til akkumulation. Udgifter til opbyggelse af en infrastruktur er nødvendige for den private akkumulationsproces og er samtidig hæmmende for den. Dette eksempel tydeligg ør også, at der er ret snævre grænser for statsintervention på grund af en strukturel finanskrise, som ikke kan overvindes indenfor kapitalistiske rammer.

Lad os endelig til sidst undersøge et tredie eksempel. Vi antager at staten fungerer som enkeltkapital, tager initiativer som en kapitalistisk virksomhed. Som ejer af kapital konkurrerer staten med andre enkeltkapitaler. Denne statsvirksomhed adskiller sig ikke fra andre enkeltkapitaler - alle er underkastet den kapitalistiske værdiproduktions og -realisations love. Staten har kun betydning 
som den formelle ejer af kapital, der er underkastet kapitalismens love, formidlet af konkurrencen. Det er tydeligt, at i dette tilfælde indsnævres de privatopererende enkeltkapitalers kapitalakkumulationsområde. Under en depression, når kapitalen ikke længere akkumulerer, kan udbygningen af en statskapitalistisk sektor indenfor den kapitalistiske $\varnothing$ konomi - blandingsøkonomi - være den eneste mulighed for at styre samfundet og behandle de voksende arbejdsløshedsproblemer og tilhørende problemer med tiltagende sociale og politiske konflikter. Denne situation var det udgangspunkt, hvorfra Keynes udviklede sin teoretiske argumentation for statsintervention, udvidelse af statsaktiviteter og forstørrelse af den statslige sektor. Men under en højkonjunktur (boom) gælder, at kapitalen også ønsker at akkumulere indenfor områder, hvor staten har eller havde størstedelen af sine aktiviteter, og ved at forblive i disse områder ville staten modvirke kapitalen i dennes drift mod stadig tiltagende akkumulation. Staten ville herigennem frembringe skærpede konflikter som ville tvinge den til at lade privat kapital akkumulere og til at begrænse den statskapitalistiske sektor, enten gennem reprivatisering, gennem en subventionspolitik eller ved andre midler. Hvis vi f.eks. ser på statsaktiviteterne i Vesttyskland efter 2. verdenskrig, er man i stand til at tegne en kurve, der er negativt korreleret med kurven for den kapitalistiske udvikling: Igennem det $» \emptyset$ konomiske mirakel « falder statsaktiviteterne relativt, mens de stiger igen i tresserne og især halvfjerserne. Dette er et udmærket eksempel på, at staten og statsaktiviteter er bundet til kapitalakkumulationsprocessen og at dette bånd selv fremtræder som strukturelle finanskriser.

Statsaktiviteternes finansielle restriktioner er påtvungne restriktioner, som udspringer af de begrænsede instrumenter, der er til statens rådighed. Det er temmelig modsigelsesfyldt, at staten skulle være i stand til at regulere en $\varnothing \mathrm{ko-}$ nomi med instrumenter, som den før fra den samme $\varnothing$ konomi; $\varnothing$ konomiens modsigelser må derfor afspejle sig som modsigelser mellem de forskellige $\varnothing \mathrm{ko}-$ nomiske styringsinstrumenter. Deraf følger, at staten ikke kan være autonom, men på grund af samfundets modsigelser, må den være særdeles forudindtaget (biased). Som konsekvens heraf må teorier som Hilferdings om staten som styrende subjekt og den organiserede kapitalisme som det styrede objekt være forkerte og falske reflektioner over den sociale virkelighed. Udover instrumenternes modsigelsesfyldte karakter (»den magiske trekant«) er der grænser for disse instrumenters effektivitet på grund af, at privat ejendomsret til produktionsmidlerne begrænser området for statslig aktivitet. Regulerende statslig $\varnothing$ konomisk politik finder sted indenfor cirkulationens område og ikke i produktionen. Den $\varnothing$ konomiske politiks instrumenter består typisk af pengepolitik, finanspolitik og politiske indgreb i forbindelse med konjunkturcyklen o.s.v. Disse instrumenter er klart kun indirekte fungerende værktøj, de er i stand til at tilskynde kapitalister til at gøre hvad politikerne $\emptyset$ nsker, eller til ikke at gøre det og i sidste tilfælde findes der i det store og hele ingen sanktioner, der kan tvinge kapitalister til at gøre der »rigtige «. 
Det er klart, at hvis staten var i stand til at tvinge kapitalister som enkeltkapitalister til at handle som om de var legemeliggørelsen af hele systemets rationalitet, ville systemet ændres til et andet, og det ville ophøre med at være kapitalistisk. Det betyder, at enten må staten indordne de individuelle kapitaler under hele systemets generelle, overordnede rationalitet eller også vil det være umuligt at nå statsinterventionernes mål, hvilket kommer til udtryk i de mange forsøg på planlægning i kapitalistiske lande. Staten må naturligvis planlægge, men planerne kan kun være retningsgivende, ikke obligatoriske. Det sidstnævnte tilfælde kræver ikke alene en ændring af samfundet, men endda en drejning af staten selv fra en parlamentarisk republik til en autoritær stat, som vi kender den i den fascistiske udgave. Jeg mener, at det umulige i at styre samfundet og pacificere det med de begrænsede instrumenter, er en af de vigtigste grunde til de forskellige fors $\emptyset \mathrm{g}$ på at undertrykke sociale modsigelser, som dæmper statsaktiviteternes effektivitet, i en repression som den brutale fascistiske. Naturligvis er den autoritære stat under kapitalistiske betingelser i et vist omfang mere effektiv end den demokratiske. Derfor er ønsket fra mange rene videnskabsmænd verden over om mere effektivitet samtidig et $\varnothing$ nske om mere effektive politiske processer, om styrkelse af den udøvende magt for at kunne gennemføre de såkaldte almene interesser mod arbejderklassens og enkeltkapitalers særlige interesser. Modsigelsen mellem instrumenternes begrænsninger og nødvendigheden af $\varnothing$ konomisk styring betyder, at der altid eksisterer en tendens i statsbureaukratiet til at løse denne modsigelse ved at udvide instrumenternes omfang og effektivitet ved en centralisering af den politiske magt og eliminering af modstående interesser på den politiske arena: demokratiets forsvinden.

Vi kommer nu til den tredie årsag til begrænsninger i statsinterventionerne, og som omfatter de sociale ejendommeligheder der udspringer af tradition, sociale erfaringer, politisk kultur og ikke mindst af forholdet mellem arbejdere og kapitalister, herunder graden af organisering i arbejderklassen. Økonomisk management betyder altid indgreb i konflikten mellem kapital og arbejde, og interventionernes effektivitet er afhængig af de to klassers styrke, henholdsvis deres organisationers. Dette forhold er næsten selvindlysende, når det drejer sig om indkomstpolitik.

Fagforeningernes karakter er f.eks. afgørende for accepten eller forkastelsen af indkomstpolitik. Fagforeningernes karakter er afhængig af erfaringerne i klassekampen, også af den teoretiske tradition, af den indre organisationsstruktur o.s.v. Naturligvis også af den generelle $\varnothing$ konomiske situation, men jeg mener, at de nævnte faktorer er vigtigere end den generelle $\varnothing$ konomiske situation. Det er måske muligt at forklare, hvorfor staten begynder med at regulere indkomster ud fra særtrækkene i et lands $\varnothing$ konomiske situation - og man kan måske sige at indkomstpolitik finder sted når der ikke findes andre midler til at forøge udbytningsraten for at opretholde en given profitrate, nødvendig for kapitalakkumulationen. Men statens hensigter kan ikke udløses automatisk, og det er tydeligt, at hindringer for at realisere indkomstpolitiske mål kan stamme fra arbejderes opposition. 
Dette forhold er endnu et eksempel på den tidligere nævnte hypotese om den $\varnothing$ konomiske og politiske kamps udelelighed. Arbejderklassens »politiske kultur « har en stor $\varnothing$ konomisk indflydelse på statens politik og naturligvis på kapitalens akkumulationsproces, og bliver således en økonomisk faktor. Det må dog fastslås, at dette forhold ikke kan bruges til at eftervise en antagelse om, at det politiske system er underkastet samfundets udvikling. Det er kun i stand til at modificere visse tendenser, og derudover formidlet af erfaringer, især af økonomiske forhold, tendenser, kampe o.s.v. Betydningen af det politiske systems modificerende effektivitet skal derfor ikke overvurderes.

Men samtidig skulle det være indlysende, at politiske faktorer for en tid kan have en meget stor effekt på statsaktiviteterne. Det er let at finde empiriske eksempler på dette. F.eks. har klassekampen i Italien skabt en situation med arbejderinitiativ som modgår ikke alene statens økonomiske politik men også kapitalens akkumulationsbestræbelser. Et andet eksempel er England, hvor de traditionelt militante arbejdere hindrer »regulerede arbejdsmarkedsforhold «, som er en forudsætning for store firmaers langtidsplanlagte kapitalakkumulation.

Det må understreges, at tradition er fremkommet alene gennem erfaringer, og erfaringer stammer fra situationer, som så igen er fremkaldt af særlige økonomiske problemer. Det ville derfor være forkert at fremhæve den revolutionære politiske tradition i den italienske arbejderklasse og fremhæve den reformistiske i den tyske eller svenske arbejderklasse. De økonomiske forhold, der kommer til udbrud i en krise, frembringer også arbejdererfaringer, som i det lange løb konstituerer revolutionær bevidsthed eller i det mindste organisationer. Det er vigtigt at undersøge den måde, gennem hvilken der nu frembringes hindringer for statsaktiviteter: Økonomiske kriser frembringer erfaringer, som konstituerer politiske strukturer og organisationsmønstre, som bliver hindringer for statens handlinger, fordi den nu organiserede og bevidste magt vil modarbejde statsinterventioner i alle de tilfælde, hvor de skader de bevidste interesser. Som Schumpeter skrev, skaber kapitalen selv strata og organisationer, som er de bedste og mest effektive kæmpere mod kapitalens herredømme.

Den sidste af de fire årsager til begrænsninger i statsaktiviteter har at gøre med staten som en nationalstat på verdensmarkedet. Der skulle imidlertid en ny forelæsning til for at tale om de modsigelser der stammer fra og er konstitutive for det kapitalistiske verdensmarked. Men alt taler for en antagelse om, at mange alvorlige konflikter i den statslige politik skyldes afhængighed af verdensmarkedet. De kan være frembragt af kriser i det internationale valutasystem, af devaluering eller revaluering af valutakurser, gennem nationalisering af industrier, at voldsomme prisbevægelser o.s.v. Disse faktorer er særdeles vigtige, fordi de har to fællestræk: for det første er de på ingen måde håndtérbare af nationalstater, og for det andet udøver de en meget stærk indflydelse på den nationale $\varnothing$ konomi. I denne sammenhæng får internationale firmaer en central betydning, fordi de udøver en $\emptyset$ konomisk magt, som får en politisk dimension ved at spille nationalstater ud mod 
hinanden for selv at maksimere profitter. For at komme ud over dette alvorlige problem forsøger nationalstaterne at kombinere deres magt for at kæmpe mod internationale firmaer og disses inflationsskabende effekter i den nationale politik. Men der er snævre grænser: Staten forbliver nationalstat, og det betyder materielt, at den kun bevidst er i stand til at regulere den nationale økonomi (indenfor de ovennævnte grænser). Selv om den skulle blive til en verdensomspændende stat - en absurd ultraimperialistisk antagelse - forbliver kapital delvis national, delvis international - en modsigelse der ikke kan løses af den borgerlige stat.

Følgerne af alt dette skulle være meget enkle: også under monopolistiske betingelser findes der grænser for statens handlinger. Disse grænser kan kun være til stede, hvis der ligeledes findes en bevægelseslov for det kapitalistiske samfund og ikke et enkelt eller simpelt forhold mellem et styrende subjekt, d.v.s. staten, og et styret objekt, d.v.s. $\varnothing$ konomien. Men dette er kun den ene halvdel, for selv under monopolistiske betingelser er staten ikke et autonomt subjekt, ikke engang i den forstand at den udelukkende er et instrument for monopolerne til at plyndre alle andre lag i samfundet. Samtidig er det imidlertid korrekt, at statsinterventionerne tiltager kvantitativt med tiltagende monopolisering. Jeg mener at begge tendenser skyldes samme årsag, nemlig tendensen til en faldende profitrate, som på den ene side tvinger kapitalen til at kompensere for den faldende profitrate gennem voksende profitmasser og på den anden side tvinger staten til at gribe ind politisk.

Denne sammenhæng mellem voksende kapital og tiltagende statsinterventioner udgør den logiske begrundelse for statsmonopolkapitalismeteorien. Men vi har nu set, at de følger, som stamokap-teorien udleder, ikke holder: især antagelsen om staten som en ret autonom institution overfor samfundet, idag under monopolernes herredømme, men imorgen takket være det antimonopolistiske folk, måske under folkets herredømme - denne antagelse forbliver problematisk. Forholdet mellem monopol og stat er mere komplekst end det antages i de almindelige stamokapteorier.

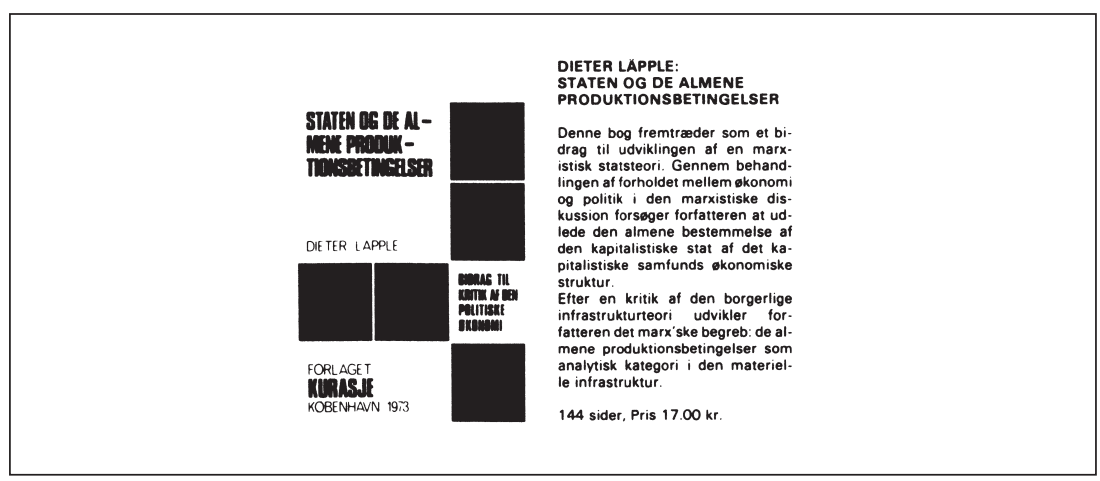




\section{Den borgerlige stats afledningsproblem*}

\section{Det borgerlige samfunds overflade, staten og produk- tionens almene rammebetingelser.}

Sybille von Flatow

Freerk Huisken

Vi bringer her første del af en artikel om den borgerlige stats polit$\varnothing$ konomiske afledning. Anden del, som bringes i næste nummer af KURASJE, beskæftiger sig med det borgerlige samfunds overflade, staten og det borgerlige samfunds overflade, den borgerlige stats funktioner og form, m.v.

Den del af artiklen, vi bringer i dette nummer, indeholder en kritik af den mangelfulde og usystematiske afledning af den borgerlige stat hos de seneste, vigtige statsdiskussionsbidrag (Müller/Neusüss, Projekt Klassenanalyse og E. Altvater), og forsøger at problematisere og præcisere, hvad man skal forstå med den borgerlige stats afledning, d.v.s. hvordan den borgerlige stat konkret kan forstås som et nødvendigt resultat af den borgerlige produktionsmåde.

* De efterfølgende overvejelser, som først er publiceret i Probleme des Klassenkampfs, nr. 7, s. 83-153, er fremkommet i forbindelse med et arrangement på Bremen Universitet. I artiklens metodiske afsnit, især afsnittene om »overflade«, støtter den sig til den diskussion, som vi har deltaget i siden begyndelsen af 1972 i Erlangen, og som vi senere har videreført i Bremen. Nogle resultater af »overflade«-diskussionen publicerede MARXISTISCHE GRUPPE/Theoriefraktion (Erlangen) i december 1972 i CIRKULAR nr. 3 under titlen »Zur Oberfläche des Kapitals«. Her bringes første afsnit; resten af artiklen vil fremkomme i det næste nummer af KURASJE. 


\section{Nogle problemer i den nuværende diskussion omkring den borgerlige stats historisk-materialistiske begreb.}

Der er påfaldende bestræbelser for at udvikle en historisk-materialistisk teori for den borgerlige stat i den nuværende rekonstruktionsfase af den marxske teori. Disse bestræbelser vanskeliggøres primært, fordi spørgsmålet om forholdet mellem kapitalens almene begreb og empiri besvares på forskellige måder eller ikke engang opstilles som spørgsmål; af den grund frembringer der også heterogene karakteriseringer og afledninger.

Forholdet mellem almen begreb og empiri kan ikke mere være et problem dér, hvor "pressede begreber « på forhånd forveksles med tilvænning til en terminologi, og hvor analysen af et konkret stykke tidshistorie ikke er et problem, idet den efter sigende allerede er tilstrækkeligt gennemført i den historisk specifikke revolutionstaktiks teoretiske grundlag (Lenins imperialisme-teori); ${ }^{1}$ altsammen fordi udvælgelsen af empiriske fænomener alene har det formål at verificere den uden spørgsmål overtagede imperialisme-teori. Denne forklaringsskematik, hvorunder også staten subsumeres, er af en besættende simpelhed hos disse grupper (»KPD«, KSV, KB-grupper, KSB..$^{2}$ ): imperialismen medfører »rædsel, elendighed, undertrykkelse, demoralisering og ruin $\ll^{3}$ og gør også statens klassekarakter stadig mere synligt, hvad den må fremme enhver tendens af som bourgeoisiets komité. Staten er her væsentlig identisk med hær, politi, retsvæsen, etc. ${ }^{4}$ Dens andre funktioner, f.eks. på socialpolitiske, arbejdsretlige eller uddannelsespolitiske områder, må, når det medfører åbenlyse forbedringer i arbejderklassens situation - tænk på det historiske eksempel med arbejdsdagens retslige regulering, fabrikslovgivningen, men også på aktuelle forholdsregler som forbedring af opsigelsesbeskyttelsen, fabrikslægelov, etc. - altid fortolkes som rent bedrag- og tilsløringsmanøvrer ifølge dette forklaringsmønster. Indskrænkningen til den egentligt tautologiske bestemmelse af den borgerlige stat som klassestat ${ }^{5}$ har som resultat, at enhver politisk fremtrædelse af denne oven

1. De to vigtigste, nyeste offentliggørelser om Lenins revolutions- og imperialismeteori har de dogmatisk-leninistiske grupperinger øjensynligt endnu ikke fået kendskab til. Vi tænker på: Ch. Neusüss, Imperialismus und Weltmarktbewegung des Kapitals, Erlangen 1972; og Projekt Klassenanalyse, LENINISMUS - neue Stufe des wissenschaftlichen Sozialismus? 2 bd., Vestberlin 1972.

2. Forkortelserne står for følgende: »KPD«: Kommunistische Partei Deutschlands, KSV: Kommunistische Studentenverband, KB-grupper: Kommunistische Bund (MarxistenLeninisten), KSB: Kommunistischen Studentenbund.

3. De vesttyske kommunisters program, særnummer af »Neuen Roten Forum«, 1972, s. 23.

4. Sammesteds, s. 25.

5. Jvf. her del IV. 
i købet bliver anvendt uformidlet på det moralsk depraverede begreb. Der må naturnødvendigt begåes et overgreb imod fremtrædelser, ${ }^{6}$ som ikke mere åbenbarer noget spor i sig at det, som træder frem, og derfor kun er tilgængelig for en analyse, når den logiske gang i fordrejningerne af den borgerlige produktionsmådes væsentlige forhold er bekendt. ${ }^{7}$ På samme måde må dette statsbegreb svigte, når det skal vise sin duelighed i opgøret med borgerlig videnskab.

Overfor den borgerlige forestilling om staten som væsensmæssig neutral, almenvælde - eller velfærdsorienteret instans findes kun udsagnet, at med en sådan teori drejer det sig kun om ren tilsløring af den sande kerne; overfor det afgørende spørgsmål, hvordan disse borgerlige teorier fremkommer, må et statsbegreb kapitulere, som metodisk er bestemt på den måde. Udvejen for de nævnte dogmatiske grupperinger forløber analog med karakteristikken af den borgerlige stats faktiske socialpolitik som værende tilsløringsman øvrer, nemlig at borgerlige forskere udtænker sådanne teorier i borgerskabets interesse. Gennem den rene modstilling af resultater fra borgerlig og marxistisk teori afkortes den marxske teoris mulige, dobbelte kritik af borgerlig videnskab - som kritik af dens resultater og som påvisning af nødvendigheden af dens fremståen; og dens tilegnelse må naturnødvendigt samtidigt blive et spørgsmål om tro, plausbilitet eller noget udenfor marxismen liggende decisionisme (stille-sigpåstandpunktet). ${ }^{8}$

Inden for de dogmatisk-leninistiske grupperingers til dels eksplicitte kritiske intention med det afkortede statsbegreb (stat som kapitalens eller monopolernes instrument, som den herskende klasses komité, som voldsog undertrykkelsesapparat) har der i nogen tid været fremført andre bestemmelser af staten i diskussionen. Disse bestemmelser forsøger på den ene side at afklare fænomener som den social- og infrastrukturpolitiske statsintervention og den objektive gåde om socialstatsillusionens reformistiske og revisionistiske oprindelse, og

6. Heri ligger iøvrigt den metodiske grund til, at der for disse grupperinger kun er to symmetriske, skæbnesvangre muligheder at forholde sig på til den forhåndenværende arbejderbevidsthed: enten konfronterer de den øjeblikkeligt foreliggende bevidsthed, hvor forkert den end også må være, med de almene kategorier for lønarbejde og kapital og dens imperialistiske kvaliteter som »råddenskab«, stagnation, elendighed, etc., og må så naturnødvendigt isolere sig som sekt; eller de tilslutter sig opportunistisk enhver »bevægelse«, uden at begrebsliggøre sig selv.

7. For at forebygge misforståelser: det påstås ikke hermed, at det er muligt med en logisk udvikling af almene kategorier frem mod empiriske fænomener. Forskellen mellem almene unders $\varnothing$ gelser, som indeholder analysen af kapitalen i almenhed, de enkelte kapitalers bevægelser under konkurrencen (= dannelsen af produktionspriser) og de overfladerelationer, som fremgår af den trinitariske formel, - og den empiriske undersøgelse af et konkret stykke tidshistorie lader sig ikke overvinde gennem empiriens afledning fra de almene undersøgelser. Jvf. f.eks. her: Projekt Klassenanalyse, Zur Taktik der proletarischen Partei. Marxsche Klassenanalyse Frankreichs von 1848-1871, Vestberlin 1972, s. $24 \mathrm{ff}$.

8. Vi går ikke her ind på Stamokap-teoriernes statsbegreb. Det er ikke, fordi beskæftigelsen med de såkaldte revisionistiske teorier ikke lønner sig, men tværtimod, fordi det kræver langt mere arbejde og er ulig mere betydningsfuld, netop i betragtning af Stamokap-teoriernes uventede publicity, som resultat af referatet fra Jusofraktioneringen. 
på den anden side bestræber de sig på at aflede demokratibegrebets indhold af ligheds- og frihedsforestillinger som karakteristika ved den borgerlige stat.

Müller/Neusüss's artikel »Die Sozialstaatsillusion und der Widerspruch von Lohnarbeit und Kapital ${ }^{9}$ bidrager her med to ting: for det første viser den det reelle grundlag for opståen af den borgerlige stats skær af klasseneutralitet ved at overtage bestemmelser fra Den tyske Ideologi - »gennem frigørelsen af privatejendom fra fællesskabet bliver staten til en særlig eksistens ved siden af og uden for det borgerlige samfund:... « ${ }^{10}$ for det andet fors $\emptyset$ ger den at begrunde n $\varnothing$ dvendigheden af den borgerlige stats socialpolitiske intervention ud fra analysen af kapitlet om arbejdsdagen i bd. 1 af »Kapitalen « $;{ }^{11}$ som tilsammen udgår fra antinomien mellem kapitalistens ret som køber og lønarbejderens ret som sælger af varen arbejdskraft. Müller/Neusüss resumerer dette aspekt: »Den ovenfor nævnte antonomi mellem kapitalistens ret som køber og arbejderens ret som sælger af varen arbejdskraft bliver ifølge Marx afgjort ved magt; den konstituerer samtidigt staten i en dobbelt karakter. På den ene side sættes statens socialpolitiske funktion overhovedet først igennem ved arbejdernes som klasse virkelige eller truende kampe; uden dem ville dens eksistens som ideel gesamtkapitalist og tilsyneladende selvstændig instans ikke være mulig. På den anden side konstituerer disse klassekampe til stadighed også arbejderen som klasse i betydningen: et handlende subjekt, men dermed også tendensen til ophævelse af kapitalforholdet og dets stat; denne tendens modsvarer atter statens militære undertrykkelsesopgaver «. ${ }^{12}$ Ud fra denne artikel er det muligt at sondre mellem bestemmelsen af den borgerlige stat som garant for opretholdelsen af den kapitalistiske produktionsmåde ${ }^{13}$ og den ovenfor anførte bestemmelse af den borgerlige stat som den herskende klasses instrument. Netop »arbejdsdags « - eksemplet viser slående, hvordan den optimale udbytning af arbejdskraften gennem enkeltkapitalerne kan true valoriseringens kilde og dermed den på lønarbejdet begrundede produktionsmåde. De nødvendige forholdsregler til opretholdelsen af den kapitalistiske produktionsmåde, som staten griber til eller er tvunget til at gribe til, kan følgelig til dels rette sig mod de enkelte kapitalers interesser. Dermed bliver det muligt udfra denne statsopfattelse at kritisere den udtværing af forskellen mellem statens funktion for enkeltkapitaler, for kapitalistklassen og for kapitalen eller totalkapitalen, som kendetegner det rent instrumentalistiske statsbegreb. Denne artikel når endnu ikke frem til en positiv bestemmelse af den borgerlige stat.

Med udgangspunkt i Müller/Neusüss forsøger yderligere to artikler at fremstille den efter vores mening mest udviklede position i diskussionen af den bor-

9. Jvf. Sozialistische Politik Nr. 6/7, 1970, s. 4 ff. Senere genoptrykt i Probleme des Klassenkampfs Sonderheft, Nr. 1, 1971, 7 ff. Udkommer på dansk februar 74 hos DSF.

10. Marx/Engels, Die deutsche Ideologi, i: MEW 3, s. 62.

11. Karl Marx, Das Kapital, MEW 23-25, Bd. 1, s. 245 ff. I det følgende henvises der også til den danske udgave, således: da. 1:2, $367 \mathrm{ff}$.

12. Müller/Neusüss, op. cit., s. 52 f.

13. Sammesteds, s. $43 \mathrm{ff}$. 
gerlige stats oprindelse og funktion. Vi vil derfor beskæftige os noget nærmere med afledningssammenhængen hos Projekt Klassen-analyse ${ }^{14}$ og hos Elmar Altvater. $^{15}$

\section{Projekt Klassenanalyse}

Projekt Klassenanalyse bebrejder Müller/Neusüss, at de til trods for henvisningen til den »særlige eksistens ved siden af og uden for det borgerlige samfund «, som nævnes som basis for socialstatsillusionens opståen, dog ikke har afledt den. Vi tilslutter os denne kritik: i stedet for den påståede konstitution af den borgerlige stat har de analyseret, hvordan bestemte forholdsregler under staten sattes igennem, og hvordan det gennemsattes form samtidigt fremkalder yderligere en statsfunktion, den militære. Hermed har de endnu ikke begrebsliggjort den borgerlige stat og dens særlige form. ${ }^{16}$

Projekt Klassenanalyse stiller sig derfor af den grund den opgave at forklare den borgerlige stats opståen som et nødvendigt produkt af det borgerlige samfund, »altså det borgerlige samfunds fordobling i samfund og stat «. ${ }^{17} \mathrm{I}$ det følgende viser den centrale kategori hos dem sig at være »fællesskabets opgaver«,

14. Projekt Klassenanalyse, Zur Kritik der »Sozialstaatsillusion«, i: Sozialistische Politik, Heft 14/15, 1971, s. 193 ff; sammes, Zur Taktik der proletarischen Partei, op. cit., s. 128 ff.

15. Elmar Altvater, $\mathrm{Zu}$ einigen Problemen des Staatsinterventionismus, i: Probleme des Klassenkampfs, Heft 3, 1972, s. 1 ff. På dansk i: KURASJE nr. 7, 22 ff. En række arbejder om staten, som vi her ikke skal gå ind på, er i den senere tid fremkommet eller for første gang blevet tilgængelig på tysk. De indeholder til dels vigtige analyser, men giver os dog kun lidt i vores centrale interesse for spørgsmålet om afledningen af den borgerlige stat som nødvendigt resultat af den borgerlige produktionsmåde. Bl.a. kan henvises til: R. Miliband, Der Staat in der kapitalistischen Gesellschaft, Frankfurt/M. 1972; sammes, Marx und der Staat, Vestberlin 1971; den i »Kritischen Justiz« (Heft 2, 1971) partiel videregivne kontrovers mellem Miliband og Poulantzas; C. Offe, Strukturprobleme des kapitalistischen Staates, Frankfurt/M. 1972; H. Gerstenberger, Elemente einer historisch-materialistischen Staatstheorie, i: Kritische Justiz, Heft 2, 1972; W. Lefevre, Zum historischen Charakter und zur historischen Funktion der Methode der bürgerlichen Soziologie, Frankfurt/M. 1971, s. 65 ff; J. Risert \& C. Roshausen, Der Konservatismus der kritischen Theori, Frankfurt/M. 1971, s. 59 ff; A. Evers, M.Lehmann, Politisch-ökonomische Determinanten für Planung und Politik in den Kommunen, Offenbach 1972.

Der skal særligt henvises til arbejdet af D. Läpple, Die allgemeinen materiellen Bedingungen der gesellschaftlichen Produktion und Staatstätigkeit in der kapitalistischen Produktionsweise. Grundlagen zu einer Kritik der Infrastrukturtheorien -, Vestberlin 1972 (Manuskript til diplomarbejde). I det findes der nogle nye henvisninger til problemet om »almene rammebetingelser «, etc., som vi imidlertid ikke kunne inddrage i vores diskussion. Senere er Läpple's bidrag kommet som bog: Staat und allgemeine Produktionsbedingungen, VSA, Vestberlin 1973; og på dansk som: Staten og de almene produktionsbetingelser, KURASJE, København 1973.

16. I del IV vil vi gå ind på det problem, om et alment begreb for den borgerlige stat måske lader sig udarbejde gennem en forudgående bestemmelse af statsfunktionerne; eller sagt på en anden måde, om den borgerlige stats »form« ikke først fremkommer ved analysen af dens »indhold «, altså statsfunktionerne.

17. Projekt Klassenanalyse, Zur Kritik..., s. 194. I det følgende henviser vi kun til den senere udgave: »Zur Taktik der proletarischen Paritei...«, s. $128 \mathrm{ff}$. 
der fremkommer af »fælles interesser«: Udviklingen af produktionens samfundsmæssighed betinger en tiltagen af disse fælles opgaver, ${ }^{18}$ som dog ikke vil kunne opfyldes af den individuelle varebesidder på grund af den kapitalistiske karakter af det samfundsmæssige arbejdes formidling. Denne modsætning kan kun løses i og med, at samfundet af private stilles op overfor samfundet som sådan, »idet altså samfundet, det almene, hvorunder de enkelte individer er subsumeret, opnår en selvstændig eksistens ved siden af og uden for totaliteten af det private, som er samfundsmæssigt konstitueret. Dette er samfundets fordobling i samfund og stat. Alle fælles interesser løsgøres fra samfundet, samfundsmedlemmerne fravristes deres selvstændighed og stilles op over for dem som almene, gennem staten forsvarede og fulgte interesser $\ll{ }^{19} \mathrm{I}$ det følgende antydes knap den borgerlige stats to funktioner, funktionen med frembringelsen af kapitalens almene produktionsbetingelser, og funktionen med opretholdelsen af den borgerlige orden gennem anvendelsen af ikke- $\varnothing$ konomisk magt. ${ }^{20}$

Går vi ud fra det af Projekt Klassenanalyse anvendte begreb »falles interesser" i »samfundet af private", der indeholder opgaver, som må opfyldes i fællesskab, synes det at være vigtigt at spørge efter det samfundsbegreb, som ligger bagved her. Det er tydeligt, at Projekt Klassenanalyse ikke anvender begrebet »samfund « identisk med »kapitalistisk produktion«. »Samfund « synes at være det sociale resultat af den foreliggende produktionsmåde, d.v.s. den specifikke sociale strukturering af en ansamling af mennesker indenfor et fiktivt nationalområde. Samfundets strukturering forbliver i Projekt Klassenanalyses afledning på sammenhobningsniveauet af enkelte private, deres indbyrdes forhold fremstilles kun gennem den gensidige ombytning af varer og gennem det deri legemliggjorte resultat af det tilhørende arbejde. Den synonyme anvendelse på dette sted af begreberne »individuel varebesidder « og »individuel vareproducent « tillader ingen anden slutning end, at afledningen af den borgerlige stat - d.v.s. afledningen af $n \phi d v e n d i g h e d e n$ af samfundets fordobling eller statens specificering - er placeret på den simple varecirkulations systematiske niveau. Individuelle vareproducenter og varebesidder falder kun sammen under betingelse af den simple varecirkulations systematiske kategorier; som privat-

18. Projekt Klassenanalyse anvender følgende begreber som synonymer: »fælles«, »a priori fælles«, »umiddelbar fælles «. Den indholdsmæssige bestemmelse kommer derved til kort. Men det drejer sig øjensynligt om »almene rammebetingelser for den samfundsmæssige reproduktion«, som er indholdet af de »fælles opgaver « og »interesser«. Vi er ikke i stand til at sige, hvor vidt disse imidlertid er identiske - som indhold af den førstnævnte af den borgerlige stats to funktioner med »almene betingelser for produktiv virksomhed «, »samfundsmæssige produktions- og cirkulationsbetingelser«, »kapitalens almene produktionsbetingelser «, »almene produktionsog cirkulationsbetingelser«, »valoriseringsprocessens almene betingelser«. Desværre gør forfatternes glæde over stilistiske variationer - alle begreber findes på siderne 130 og 131 - det meget svært eksakt at eftervise den yderst komprimerede afledning.

19. Projekt Klassenanalyse, Zur Taktik..., s. $130 \mathrm{f}$.

20. Sammesteds, s. $131 \mathrm{f}$. Vi går yderligere noget nærmere ind på disse to funktioner senere (del IV). Her interesserer vi os kun for de almene afledningssammenhænge. 
ejer af midler og instrumenter til arbejdets genstandsgørelse og som ejer af det tilhørende arbejdes resultat, varen kan disse tilegne sig resultatet af fremmed arbejde som brugsværdi i cirkulationsforløbet V-P-V. De to kategoriers særegenheder, som Projekt Klassenanalyse tidligere har udviklet, ${ }^{21}$ ud fra kapital og ud fra arbejdskraft, synes ikke at få konsekvenser for statsafledningen. Med mindre samfundsmedlemmernes privathed omfatter lønarbejdets $o g$ kapitalens privatinteresse, og at denne privathed eller dennes resulterende interesse lader sig begribe på den eller anden måde som faelles interesser. Men netop dette problem bliver ikke afklaret: hvori kan det private, som hører til disse to forskellige samfundsklassers fælles interesser, da bestå? Hvori består det almene, hvorunder det særskilte individ - og da vel det, som besidder varen arbejdskraft og det, som besidder produktionsmiddel - synes subsumerbar på samme måde? Eller tillader kategorien »fælles interesser« kun kapitalbesidderens eksklusive fællesskab? Hvis det er sådan, så vil Projekt Klassenanalyses samfundsbegreb på samme måde være eksklusiv.

Udfra bestemmelsen af forskellen og ligheden mellem de to særskilte kategorier af varebesiddere kan man nu ganske vist svare: den kvalitet, som gør alle varebesiddere - ud fra disse varers forskellige arbejds- og ejendomsrelationer og uden hensyntagen til varernes $\varnothing$ konomiske bestemmelse - til forskelsløse private individer, er deres ligestilling $i$ bytningen. De eksisterer dog »i bytteprocessen som individuelle varebesiddere, hvor enhver forfølger sin privatinteresse «. ${ }^{22}$ I bytteakten står de overfor hinanden som frie og lige varebesiddere.

Kan man til at begynde med være enig, ${ }^{23}$ så opstår dog påny det gamle spørgsmål på varieret måde: hvordan lader folles interesser sig aflede af ligestillede besiddere af forskellige varesorter? Hvortil kan de fælles interesser overhovedet henføres, når dette fællesskab til syvende og sidst kun udtrykker ækvivalensrelationen i bytteakten, d.v.s. lighed i størrelsen af varer, som står over for hinanden, men abstraheret fra den $\varnothing$ konomiske funktion af den foreliggende vare såvel som fra den forudsatte ejendomsrelation hos besidderen af de to særskilte arter af varer? Man kan formodentlig give det svar, at staten garanterer alle varebesidders fælles interesse i sikring af betingelsen for ækvivalensbyttet. Selvom et sådant svar også er utilfredsstillende, fordi det ikke forklarer, hvordan varebesiddere kan formulere interesser ved at se bort fra den kapitalistiske formbestemthed af deres foreliggende varer, ${ }^{24}$ så har dog et sådant svar den fordel, at det direkte henviser til de opstillede forudsætninger. Dog falder svaret, som allerede nævnt, afgjort anderledes ud: indholdet af de privates fæl-

21. Sammesteds, s. 129.

22. Sammesteds.

23. I afsnit I. 3 går vi noget nærmere ind på spørgsmålet om forholdet mellem den simple varecirkulation og statsafledning.

24. Vi påstår ikke, at dette er umuligt. Blot mangler hos Projekt Klassenanalyse udviklingen af det niveau, hvor de forskellige varer selv ikke mere fremtræder for deres respektive ejere i deres kapitalistiske formbestemmelse, men som ens indkomstkilder. Jvf. del II. 
les interesser er fællesskabets opgaver, som nærmere bliver kendetegnet som »almene rammebetingelser for den samfundsmæssige reproduktion $\ll .{ }^{25} \mathrm{Og}$ den må staten - under bestemte betingelser ${ }^{26}$ - »opfylde $i$ modsatningen til arbejderklassens interesser $« .{ }^{27}$ Selvom vi netop møjsommeligt har forsøgt at udarbejde det samfundsbegreb, der står bag statsafledningen, som sammenhobning af ligestillede private i bytterelationen, så bliver her igen det samfundsbegreb uformidlet bragt på bane, som udtrykker det kapitalistiske samfund som antagonistisk klassesamfund. De »fælles interesser « er her igen glemt, den antagonistiske interessesituation presses uformidlet i forgrunden. Den individuelle varebesidder, som ind til da alene var betragtet udfra varesælgerens synsvinkel, men ved at se bort fra selve varens legemliggjorte arbejdsforhold og ejendomsrelation, præsenterer Projekt Klassenanalyse nu som ejendomsløs og udbyttet klasse, som ikke besidder antydningen af fællesskab med sin udbytter.

Springene og meningsløshederne i Projekt Klassenanalyses statsafledning lader sig sammenfatte på følgende måde: den almene bestemmelse af den borgerlige stats form som samfundets specificering er bygget op på et andet metodisk niveau end bestemmelsen af den borgerlige stats to almene funktioner. Bestemmelsen af den borgerlige stats form er resultatet af en uformidlet sammenstykning af den simple varecirkulations bestemmelser [ligestillede individuelle vareproducenter, de privates fælles interesser] med teoremet om de almene rammebetingelser for den samfundsmæssige produktion og reproduktion [fællesskabets opgaver ${ }^{28}$ ], som ville forudsætte gennemførelsen af bestemmelsen af enkeltkapitalernes konkurrence. Heroverfor udtrykker de to almene statsfunktioner den kapitalistiske produktions antagonistiske karakter rent i form af klassemodsætningen. I den indholdsmæssige bestemmelse af den borgerlige stats funktioner kommer dens karakter som »instrument for den herskende klasse $\ll^{29}$ til udtryk; den form, hvori den fremsættes, tilslører igen klassekarakteren. ${ }^{30}$ Dermed kan vores kritik først og fremmest reduceres til

25. Sammesteds, s. 130.

26. »Disse almene produktionsbetingelser for kapitalen - til forskel for hver enkeltkapitals specielle - frembringes af staten, såsnart de er nødvendige for kapitalens valorisering, men deres fremstilling enten ikke er profitabel nok til at blive drevet som selvstændig anbringelse af de enkelte kapitaler, eller på grund af enkeltkapitalernes udvendige sammenhæng i produktionsprocessen (?)«, sammesteds, s. 131.

27. Sammesteds, s. 131.

28. Jvf. her »vejbygnings«-eksemplet hos K. Marx, Grundrisse der Kritik der politischen Økonomie, Østberlin 1953, s. 422 (om muligt henvises der også til det danske udvalg af Grundrisse i det følgende). Først i del $V$ vil vi gå end på de vanskeligheder, som forsøget medfører, ved at aflede staten ud fra denne sammenhæng.

29. Projekt Klassenanalyse, Zur Taktik..., s. 131.

30. Dette er f.eks. også meget tydeligt på det følgende sted: Statens funktion som instrument til opretholdelsen af den borgerlige orden »er skjult bag den legitimation, hvorigennem de individuelle varebesidderes gennem retslige normer, der er fikseret som love om varecirkulationens frihed og lighed. Denne specifikke foranstaltning er samtidig grundlaget for illusionen om staten som repræsentant for hele samfundets interesser«. Sammesteds, s. 132. 
et eneste spørgsmål: hvordan er det logisk muligt, at den borgerlige stats opståen som »sarlig eksistens ved siden af og uden for det borgerlige samfund « er resultatet af artikulationen af alle varebesidderes falles interesse $i$, at faellesskabets opgaver udføres, når disse opgaver til sidst alene kendetegnes ved den herskende klasses interesse, altså besidderen af den sarlige vare kapital (som penge- eller varekapital)? Og: skyldes det kun cirkulationen, at bestemte, nфdvendige opgaver (produktionens og reproduktionens almene rammebetingelser) forekommer besidderen af varen arbejdskraft at vare $i$ hans interesse, sk $\phi$ t disse opgaver strider mod hans interesser?

I Projekt Klasseanalyse findes der intet svar på disse spørgsmål. Problemet vedrørende formidling mellem niveauerne, som projektet permanent springer hid og did imellem, er endnu ikke løst; nemlig formidlingen mellem det niveau, hvor samfundsmedlemmerne er stillet lige og følgelig lader sig subsumere under noget alment, og det andet niveau, hvor de gennem forskelligt klassetilhørsforhold - men også som indbyrdes konkurrerende - må gøre deres særlige og til dels modstridende interesser gældende.

Før vi selv forsøger at give et foreløbigt svar på disse spørgsmål, skal der ved hjælp af E. Altvaters artikel endnu antydes yderligere et problem.

\section{E. Altvater}

Også hos E. Atlvater spiller produktionens og reproduktionens almene rammebetingelser en afgørende rolle. Hans udgangspunkt er imidlertid ikke den simple varecirkulations systematiske niveau, men enkeltkapitalernes bevægelser under konkurrencen. Han vil kun kaste sig over en side af den »statslige aktion «, »nemlig dens aktioner overfor de mange enkeltkapitaler. For vores problem bliver det afgørende spørgsmål, hvorledes den reelle sammenføjning af det bestående samfund følger af de mange enkeltkapitaler og hvilken betydning, der derved tilkommer staten $\ll .{ }^{31}$ Konkurrencen som den form, i hvilken kapitalens immanente love sætter sig igennem gennem enkeltkapitalernes indbyrdes forhold, er ifølge Altvater dermed samtidigt den form, i hvilken de samfundsmæssigt nødvendige funktioner, som ikke er centrale bestemmelser for merværdiynglen, ikke lader sig udføre. Derfor udgør sådanne funktioner ${ }^{32}$

31. E. Altvater, Zu einigen Problemen..., PROKLA s. 5 (som nævnt findes artiklen på dansk i KURASJE nr. 7, hvortil der henvises således: da. s. 26). En »anden side«, som E. Altvater ikke vil gå end på, er bestemmelsen af staten som »organ for kapitalens herredømme over lønarbejderklassen « (s. 5; da. s. 26). Han gør det dog ganske vist kursorisk i udredningen af statens rolle i konflikten mellem lønarbejde og kapital (s. 14; da. s. 32-33).

32. Til at begynde med bestemmes disse funktioner kun negativt ud fra konkurrencen: »Det er ikke alle samfundsmæssige funktioner, som lader sig udføre kapitalistisk i denne betydning, hvad enten det er, fordi produktionen af visse (materielle) produktionsbetingelser ikke afkaster profit, eller fordi mange ordninger besidder en for stor grad af almenhed til, at enkeltkapitalerne med deres særinteresser kan realisere dem under de foreliggende konkrete betingelser« 
en $n \varnothing d v e n d i g$ komplement til konkurrencen $\mathrm{i} \gg$ den reale sammenføjning af det samfund, som består af mange enkeltkapitaler «, men de lader sig ikke realisere $i$ konkurrencens form. »Kapitalen kan således ikke af sig selv producere den samfundssige eksistens, som er anlagt i den, gennem de mange enkeltkapitalers handlinger; den behøver en særlig indretning på sit eget grundlag, som ikke er underlagt dens grænser som kapital, hvis handlinger altså ikke er bestemt af merværdiproduktionens nødvendighed - en særlig indretning som i denne forstand er 'ved siden af og uden for det borgerlige samfund', og som på kapitalens uantastede grundlag samtidigt kan opfylde de immanente nødvendigheder, som kapitalen fors $\phi m m e r \ll .{ }^{33}$

I et graverende $»$ hul $« \mathrm{i}$ det borgerlige samfunds funktioner rykker her skarpt formuleret - en deus ex machina ind i form af »indretningen« den borgerlige stat. Ligestillingen af »totalkapital « og »samfund « ${ }^{34}$ indeholder herved en lignende amputation af samfundet, som det delvis var tilfældet med Projekt Klassenanalyse. Samfundet som resultat at kapitalbesidderens indbyrdes forhold placerer den, som ikke besidder andet end sin arbejdskraft, uden for den samfundsmæssige sfære. Hans eksistens som varebesidder i cirkulationen, som Projekt Klassenanalyse dog ville smugle denne gruppe af samfundsmedlemmer ind $\mathrm{i}$ andensteds, falder ud, det samme gør hans interesser - hvad enten de er almene interesser eller særinteresser. Præcis sagt fremtræder staten hos Altvater af den grund heller ikke som det borgerlige samfunds »fyldekalk«, men som totalkapitalens »tilsætningsorgan «.

Denne argumentation kan efter vores skøn måske tjene som negativ udgangspunkt for begrundelsen af den almene nødvendighed af statens specificering. Ikke desto mindre er intet gjort i retning af den positive bestemmelse med påvisningen af vanskeligheden med garantien for og fremstillingen af bestemte produktionsforudsætninger. Påvisningen af, at noget må ske, erstatter ikke beviset for, under hvilke almene betingelser noget overhovedet kan ske. En positiv afledning af staten i dens borgerlige bestemmelse betyder udviklingen af de betingelser, hvor sådan noget som »stat « overhovedet kan konstitueres. Med andre ord: såsnart udfoldelsen af kapitalens indre natur som indbyrdes vekselvirkning af mange enkeltkapitaler såvel som værdilovens gennemslagsform og skranken for selve dens samfundsmæssige realisering er blevet påvist, er alene den tendentielle nødvendighed af overvindelsen af sådanne skranker positivt bestemt, men den sfære, i hvilken eller ud fra hvilken det kun kan ske, er dog ikke allerede positivt afledt. Staten forekommer i denne afledning kun som almen erfaringskendsgerning, ikke som logisk bestemt.

(sammesteds, s. 7; da. s. 27). Senere nævner E. Altvater så en oversigt over fire funktioner, som han så gør nærmere rede for (s. 9 ff; da. s. 29 ff). I del IV går vi mere ind på denne oversigt.

33. Sammesteds, s. 7; da. s. 28. Fremhævelse F \& H.

34. Jvf. her s. 5; da. s. 26: »... reale sammenføjning af det samfund, som består af mange enkeltkapitaler...«; (fremhævelse F \& H). 
En sådan positiv bestemmelse synes hos Projekt Klassenanalyse at følge af varecirkulationens betingelser. Dog var den ligestilling, som gjorde individerne subsumerbare under noget alment, placeret på kapitalbegrebets systematiske udviklingsniveau, hvor den samfundsmæssige antagonisme mellem lønarbejder og kapital endnu ikke én gang lader sig fremstille, og hvor den måde, som antagonismen i sin fordrejede form atter ophæves på, langt mindre lader sig udvikle. Et sådant fors $\emptyset$ g mangler hos Atlvater. ${ }^{35}$ Problemet forekommer derfor mere klart hos ham.

Vi kan nu afslutte den kursoriske unders $\emptyset$ gelser af to aktuelle statsafledninger og nok én gang resumere de spørgsmål, som følger heraf.

\section{Statsafledning og simpel varecirkulation}

Kravet om at være en korrekt »afledning « af den borgerlige stats særegenhed ud fra kapitalbegrebet (»Kapitalen«, bd. 1-3) betyder at bestemme den systematiske sammenhæng, hvor udfra dette »politiske« område opstår af den » $\varnothing$ konomiske « form, ${ }^{36}$ og at påvise nødvendigheden af udfoldelsen af denne form hos den borgerlige stat. Det er tidligere blevet betegnet som den borgerlige stats specificering eller som det borgerlige samfunds fordobling i samfund og stat. ${ }^{37}$

For såvidt udviklingen af kredittens funktion måske først er muligt efter udfoldelsen af pengenes bestemmelse som betalingsmiddel, cirkulationslovene, specielt hvordan de følger af pengekapitalens kredsløb, profitraten og udviklingen af den rentebærende kapital, så må det også være muligt - udfra den $\varnothing$ konomiske sammenhæng, som det borgerlige samfunds »politiske « udvikling opstår af - at angive de logiske forudsætninger og samtidigt at udvikle kriterierne for deres aftegning i processen. Det tillader en differentieret udbredelse af de love og forhold, som er virksomme i dette »politiske « område. Man må dog samtidig undgå den fejltagelse at antage, at kreditten allerede er logisk udviklet eller mulig at udvikle, overalt hvor Marx omtaler kreditten - for at komme tilbage til kredit-eksemplet.

35. Efter vores skøn ligger betydningen af E. Altvaters artikel mindre i fors øget på en statsafledning, og mere i fors øget på en noget mere differentieret undersøgelse af betingelserne for fremstillingen af de almene, materielle produktionsbetingelser gennem staten. Hans adskillelse mellem »fremstilling « og »drift« (s. 20; da. s. 38) bidrager vel også til afklaringen af nogle afsnit $\mathrm{i} »$ vejbygnings «-eksemplet i Grundrisse, som trænger til fortolkning.

36. Angående problemet med begrebene »politisk« og »økonomisk«, jvf. note 106.

37. Vi vil ikke her gå ind på en fortolkning af den knappe antydning af en bog om staten i brevet fra Marx, men der skal henvises til en opbygningsplan, hvor Marx gør implicitte bemærkninger om forholdet mellem samfundsbegreb: »VI. Kapitalen som rigdomskilde. Kapitalisten. Efter kapitalen skal grundejendommen behandles. Derefter lønarbejdet. Forudsat alle tre, prisernes bevægelse, som cirkulationen bestemt nu i dens indre totalitet. På den anden side de tre klasser som produktionen sætter i dens tre grundformer og cirkulationens forudsætning. Så staten (staten og borgerligt samfund - skatten, eller eksistens af den uproduktive klasse...) «. Grundrisse, s. 175. 
Kreditten optræder således på talrige steder i Kapitalens bd. 1 og særligt i bd. 2, uden at man formår at sige mere om den, end at det drejer sig om penge, som kommer et eller andet sted fra, og overvinder cirkulationens skranker, altså f.eks. kan formindske omslagshastigheden etc. Hvis man på den måde betragter kreditten som tilstrækkeligt bestemt ved at angive, hvor den for tiden kan træde ind som brandkorps, så ville man omtrent bære sig ad som Altvater med staten, der hos ham også kun fremtræder negativt som »fyldekalk «. Men nu optræder kreditten også i andre relationer. Der, hvor Marx unders $\emptyset$ ger $»$ merværdiens cirkulation $«{ }^{38}$ udvikler han samtidigt pengekapitalens frigørelse ${ }^{39} \mathrm{og}$ dermed en almen forudsætning for, at kreditten som kapitalform reelt kan fremstå.

I undersøgelsen af kapitalens lovmæssighed, for såvidt den resulterer af kapitalens cirkulationsproces, er der dermed implicit angivet - ved siden af nogle konkrete eksempler på dens funktion - de almene forudsætninger for, at kreditten kan unders $\varnothing$ ges i dens eksplicitte form og rolle i den videreløbende udvikling af kapitalbegrebet. Netop derfor er det uundgåeligt at udvikle kategorien profitrate, hvis udligningsproces det er kredittens hovedopgave at formidle. ${ }^{40}$

Overfører vi dette metodiske eksempel på statsafledningsproblemet, så kan vi præcisere: det er hverken tilstrækkeligt at bestemme de almene forudsætninger, som implicit findes i kapitalbegrebets udvikling, for den borgerlige stats eksistens, eller at ville konstituere den som summen af dens faktiske aktiviteter, men man må finde det metodiske udgangspunkt, hvor udfra staten bliver nødvendig som en real eksistens: her udsondres - for at gribe til én af Marx's vendinger fra en anden sammenhæn ${ }^{41}$ - »den indre tendens som ydre nødvendighed « i den systematiske udviklingsgang.

Det afgørende indholdsmæssige spørgsmål er allerede givet: udfra hvilken sammenhæng etableres nødvendigheden af den eksplicitte fordobling af samfundet i samfund og stat?

Det fører til at begynde analysen af staten analogt med værdiformens dialektik, d.v.s. med modsigelsen mellem bytteværdi og værdi, som resulterer i fordoblingen af varen i vare og penge. Müller/Neusüss har også trukket denne udviklingsproces frem som begrundelsen for den borgerlige stats specificering: »Pengene fremtræder nu som en selvstændig ting, som værdiens særlige, historisk-samfundsmæssige egenskab klæber ved som en naturlig... egenskab. Den samme 'fetichisme' kan konstateres ved statens form. Ifølge den borgerlige

38. Das Kapital, II, s. 321 ff; da. 2:2, s. 415 ff; jvf. også Das Kapital, II, s. 513; da. 2:2, s. 657-58.

39. Das Kapital, II, s. 323; da. 2:2, s. 417.

40. Das Kapital, III, 451; da. 3:2, s. 567; Grundrisse, s. 418.

41. Grundrisse, s. 317. Samtidigt skal det understreges, at det med denne metodiske unders $\varnothing$ gelse ikke drejer sig om en analogisering, men kun om illustrationen af en fremgangsmåde ved hjælp af eksempler. 
opfattelse har staten enten altid været, er mennesket skabt af naturen på grundlag af staten, eller er staten uundværlig for det menneskelige (d.v.s. borgerlige) liv... At den blot er specificering af denne specifikke produktionsmåde, den kapitalistiske, er i denne forvridning vendt på hovedet « ${ }^{42}$ Müller/Neusüss bliver ved den formale analogi, uden at den nødvendiggjorte modsigelse i statens specificering samtidigt er blevet udviklet. Medens pengefetichen kan påvises som bevægende motiv ved modsigelsen mellem bytteværdi og værdi, er stat den tingslige form af noget ubekendt. De fordrejede forestillinger, som resulterer af selve statens form (der har altid været en stat; mennesket som et væsen skabt at staten...), kan ikke samtidigt angives som årsag til feticheringen. Hos Reichelt optræder den samme sammenhæng og den føres tilbage til »en dobbelthed hos to interessesituationer, karakteristisk for den borgerlige eksistensmåde «, ${ }^{43}$ som Marx og Engels allerede i »Den tyske Ideologi« har erklæret for at være statens grundlag: udfra »modsigelsen mellem sarinteresser og falles interesser antager den fælles interesse som stat en selvstændig skikkelse, adskilt fra de virkelige enkelt- og totalinteresser... «44

Noget lignende er allerede dukket op i Projekt Klassenanalyseres statsafledning og kan her igen mere præcist stilles som spørgsmål: på hvilket udviklingsniveau af kapitalbegrebet fremkommer hin modsigelse mellem almen henholdsvis fælles og sær-interesser, som har den nødvendige fordobling af samfundet som resultat?

Findes en sådan modsigelse allerede på den simple varecirkulations bebrebslige niveau (jvf. Projekt Klassenanalyse) på en sådan måde, at den kan begribes som resultat af den kapitalistiske form for produktion?

Svaret må indeholde både reflektion over kategorien »interesse « såvel som over kategorien »samfund «; da den sidstnævnte efter vores sk $\varnothing$ n forudsætter kategorien »klasse«, som først medlemmer i et samfund med kapitalistisk produktion er i stand til at strukturere tilstrækkeligt, så forudsætter den første nødvendigvis skelnen mellem karaktermaske og subjekt, fordi interesser kun i såfald kan ytres, når der består en begrebslig forskel mellem objektiv bestemmelse af ting (penge, vare, kapital) og dens $» \operatorname{vogter} \ll{ }^{45}$ bærer, besidder..., hvilket på den anden side overhovedet kun lader sig aflede af muligheden for den stedse værende adskillelse mellem bevidsthed og den borgerlige produktions væsentlige lovmæssigheder.

I virkeligheden synes den simple varecirkulations begrebslige niveau nu foreløbigt at være det angrebspunkt, hvorfra i det mindste enhver ligestilling, som kommer til udtryk i fælles henholdsvis almene interesser, kunne afledes. Thi: »For at sætte disse ting i forhold til hinanden som varer, skal varebesidder-

42. Müller/Neusüss, op. cit., s. 54 .

43. H. Reichelt, Zur logischen Struktur des Kapitalbegriffs bei Karl Marx, Frankfurt/M. 1970, s. 63.

44. Marx/Engels, Die deutsche Ideologie, op. cit., s. 33. Fremhævelse F \& H. 
ne forholde sig til hinanden som personer, hvis vilje har til huse i de pågældende ting, således at den ene kun med den andens samtykke, begge altså kun ved en fælles viljeakt, tilegner sig den andens vare samtidig med at afhænde sin egen. De må derfor gensidigt anerkende hinanden som privatejere. Dette retsforhold, hvis form er kontrakten, er et viljesforhold, hvori det økonomiske forhold genspejles. Indholdet i dette rets- eller viljesforhold er givet gennem selve det $\phi k o-$ nomiske forhold « ${ }^{45}$ D.v.s. privat besiddelse af produktionsbetingelser, produktionsmidler, og dermed af privatarbejdets resultater, selve produktet, »frihed, lighed, ejendom og Bentham ${ }^{46}$ behersker den simple varecirkulations sfære gennem formen V-P-V. I Kapitalens første bind udvikler Marx bestemmelsen af den simple varecirkulation før analysen af merværdiens opståelsesproces og dermed før den positive bestemmelse af kapital. Den simple varecirkulation er dermed - for en gangs skyld set bort fra den historiske dimension ${ }^{47}$ et systematisk skridt på vej fra penge til kapital. I den simple varecirkulation tjener penge kun som cirkulationsmiddel i varens metamorfose. Men samtidig med fikseringen af bytteværdi i penge er det en vigtig mulighed at kunne løsgøre sig fra bestemmelsen som cirkulationsmiddel: »Men forsåvidt som bytteværdien som sådan fikseres i penge, står brugsværdien kun over for den som abstrakt kaos; og netop i og med dens adskillelse fra sin substans falder den sammen med sig selv og forsvinder fra den enkle bytteværdis sfære, hvis højeste bevægelse er den enkle cirkulation $\ll{ }^{48} \mathrm{Ud}$ fra denne placering af den simple varecirkulation i kapitalbegrebets logiske udviklingsgang bliver dens videre bestemmelse forklarlig:

Tilfredsstillelsen af behov er cirkulationens udgangspunkt og slutpunkt. »Kredsløbet V-P-V begynder med en vare som yderpunkt og slutter med en anden vare som yderpunkt, og denne vare udgår af omsætningen og indgår i forbruget. Forbrug, tilfredsstillelse af behov, kort sagt brugsværdi er derfor dette kredsløbs endelige mål «. ${ }^{49}$

Dette indebærer, at varens brug, dens konsum, ligger helt uden for cirkulationen; »det angår ikke forholdets form;... og er en ren stoflig interesse, som kun udtrykker et individ A's forhold i hans naturlighed til en genstand for hans enkle behov. Hvad der begynder med varen..., er et spørgsmål, som ligger

45. Das Kapital, I, s. 99; da. 1:1, s. 186.

46. Das Kapital, I, s. 189; da. 1:1, s. 292.

47. Marx antyder talrige steder, at bestemmelsen af den simple varecirkulation også samtidigt indeholder en historisk realitet (jvf. f.eks. Das Kapital, I, s. 128. note 73, da. 1:1, s. 219, note 73; Das Kapital, I, s. 184, da. 1:1, s. 285; Das Kapital, III, s. 354, da. 3:2, s. 446-47; Grundrisse, s. 915; etc.). Ud fra denne oplysning kan der dog ikke afledes eksistensen af en hel historisk fase eller periode med den simple varecirkulation i den kapitalistiske produktionsmåde (jvf. Das Kapital, III, s. 909; da. 3:4, s. 1154). I sin Leninundersøgelse henviser Projekt Klassenanalyse hertil. (Jvf. Projekt Klassenanalyse, Leninismus..., s. 76 ff).

48. Grundrisse, s. 179; da. s. 95.

49. Das Kapital, I, s. 164; da. 1:1, s. 262. 
udenfor de фkonomiske forhold «. [»Her (ved byttet af arbejdskraft mod kapital; forf.) fremtræder omvendt den brugsværdi, tilbyttet med penge som særlig, $\varnothing$ konomisk forhold, og bestemt anvendelse af det med penge tilbyttede udgør det sidste mål med begge processer. Dette adskiller allerede formelt byttet mellem kapital og arbejde fra det simple bytte - som er to forskellig processer «.]. ${ }^{50}$

Tilegnelsen af brugsværdier (varen) i byttet, d.v.s. resultat af fremmed arbejde gennem bytteværdi, forudsætter ejendom, grundet på eget arbejde; således at kun på bases af eget arbejde, vil resultatet af fremmed arbejde kunne tilegnes. ${ }^{51}$

I virkeligheden finder vi lighed i enhver relation under den simple varecirkulations systematiske betingelser: på alle deltagende sider i den simple bytteakt hersker der samme intentioner, de samme ejendomsforhold, de samme tilegnelsesforhold, helt bort set fra de deltagende tings (vare, penge) ækvivalensrelation i bytteakten: »Det er umuligt at opspore nogen forskel eller modsætning mellem dem, ikke engang forskellighed $\ll,{ }^{52}$ når man ser bort fra forskellige behov rettet mod forskellige brugsværdier, som dog netop udtrykker grundlaget for varebesidderens sociale og $\varnothing$ konomiske lighed..$^{53}$

Det vil betyde forvekslingen af to ting at ville aflede staten allerede her, f.eks. ud fra modsigelsen mellem de enkelte varebesidders egenkærlige interesser og deres fælles interesser i opretholdelse af byttebetingelser, nemlig forveksling mellem den almene basis for forestillingerne om frihed og lighed, ${ }^{54}$ som først og fremmest afledes af den simple varecirkulations systematiske betingelser, med det friheds- og lighedsniveau, som først og fremmest fremstiller resultatet af udviklingen af den kapitalistiske produktionsmådes differentia specifika. Der må endnu her abstraheres fra denne, altså fra adskillelsen af ejendom og arbejde og fra merværdi- og kapitalproduktionens love, som den bygger på, hvis staten skal udvikles som logisk resultat af pengenes funktion indenfor den simple cirkulation.

Frihed og lighed var udviklet under den simple varecirkulations betingelser såvel i den formelle cirkulationsakt som i dens indholdsmæssige forudsætninger (ejendomsforhold, intention, tilegnelsesform); hverken friheds- eller lighedsbegrebet lader sig opretholde i en omfattende betydning under den simple varecirkulations indhold og form, når produktionsmådens basis er ejendommens adskillelse fra arbejdet og når den medfører den karakteristiske modsigelse mellem ejendom og ikke-ejendom.

Lighed og frihed bliver alene relateret til den formelle bytteakt, til den lige akvivalensrelation, hvor der ses bort fra ejendoms- og tilegnelsesfor-

50. Grundrisse, s. 185 f; fremhævelse F \& H.

51. Grundrisse, s. 902 f, 185; og s. 414 (da. s. 251-52).

52. Grundrisse, s. 153; da. s. 76.

53. Grundrisse, s. 154; da. s. 77.

54. »Lighed og frihed er altså ikke blot respekteret i den bytning, der beror på bytteværdi, men bytningen af bytteværdier er den produktive, reelle basis for al lighed og frihed«. Grundrisse, s. 156 ; da. s. 81 . 
hold, fra den nu differentierede intention hos varevogteren og fra den tilbyttede vares forskellige $\varnothing$ konomiske bestemmelse. Bytteforholdet mellem kapitalist og arbejder som bytterelation, der præsenterer frihed og lighed, bliver »et ydre skin, der er fremmed for selve indholdet og kun mystificerer det. Det stadige $k \varnothing b$ og salg af arbejdskraften er formen. Indholdet er det, at kapitalisten uden ophør omsætter en del af det fremmede arbejde, der allerede er materialiseret, og som han uafbrudt tilegner sig uden ækvivalent, mod at få en stadig større mængde levende fremmed arbejde i stedet. Oprindeligt fremtrådte ejendomsretten for os som begrundet i eget arbejde... Egendom fremtrader nu på kapitalistens side som retten til at tilegne sig fremmed, ubetalt arbejde eller dettes produkt og på arbejderens side som det umulige $i$ at tilegne sig sit eget produkt $\ll{ }^{55}$ Det relaterer sig ganske vist ikke til alle bytterelationer på basis af kapitalistisk produktion. Går vi ud fra pengekapitalens metamorfose

$$
\mathrm{P}^{\mathrm{V}}{ }_{-\mathrm{A}}^{-\mathrm{PM}} \ldots \mathrm{P} \ldots \mathrm{V}^{\prime}-\mathrm{P}
$$

så relaterer opdelingen af ejendomsforhold og bytteforhold, byttes form og indhold, sig kun til handlingen P-A, penge mod arbejdskraft, henholdsvis pengekapital mod arbejdskraft. I bytteakten P - PM er forsåvidt også enhver lighed varetaget indholdsmæssigt, da den ene kapitalists pengekapital byttes med den anden kapitalists (altså ejer af produktionsmidler) varekapital. Begges ejendom er kvalitativ lige, og er kapital (fra da af i dens $\varnothing$ konomiske funktion forskellig fra betingelserne for den simple varecirkulation i hvilken ejendommen hos de to deltagende i bytteprocessen ganske vist var kvalitativ lige, men ikke kapital, men derimod primær produktionsmiddel med den funktion at garantere deres ejendoms reproduktion). I bytteakten V' - P' har vi så, når V' stofligt udtrykker sig i PM, de samme betingelser som under P- PM. Anderledes forholder det sig, når V' legemliggøres i livsfornødenheder (LN). Så byttes der ikke mod penge som pengekapital, men mod penge som revenu, hvis bestemmelse ligger i det til enhver tid gældende forbrug af deres vareækvivalenter. ${ }^{56}$ Revenuens form spiller derved foreløbig ingen rolle, for om revenuen fremtræder som løn for uproduktiv eller produktiv arbejde, som rentedel eller driftsherregevinst, ændrer intet ved dens $\varnothing$ konomiske funktion, nemlig at danne det individuelle konsumtionsfond. Afgørende kvantitative forskelle i konsumtionsfondet lader sig derimod spore, den kan på den anden side ikke desto mindre føres tilbage til kvalitative forskelle, som vi allerede har konstateret. I P-A udtrykker P den værdistørrelse af arbejdskraften, som udtrykkes i lønnen; i P-PM udtryk-

55. Das Kapital, I, s. 609 f; da. 1:4, s. 825-26; jvf. Grundrisse, s. 194 f; da. s. 111.

56. Jvf. de to revenubegreber, Das Kapital, I, s. 618, note 33; da. 1:4, s. 835, note 33. 
ker P de penge, som besidderen realiserer i den PM legemliggjorte merværdi, hvorfra en del af hans revenu dannes. Den afgørende forskel er dermed allerede indeholdt i P-V ${ }_{A}^{-P M}$ den optræder formidlet igen i V' (LN) -P' (revenu). Indenfor totaliteten af bytteprocessen har vi at gøre med noget, hvori de byttendes lighed formelt og indholdsmæssigt kommer til syne (P-PM; eller V'(PM)P'), men også med noget, hvori alene den formelle lighed kommer til syne (P-A).

Hvis frihed og lighed under den simple varecirkulations abstrakte betingelser var givet $»$ if $\varnothing l g e$ kendsgerningerne $\ll^{57} \mathrm{i}$ byttet $o g$ de byttendes grundlæggende økonomiske ejendoms- og tilegnelsesforhold, så bliver de »ved betragtning af mere konkret $\varnothing$ konomisk forhold som den simple cirkulation, den udtrykker ${ }^{58}$ til byttes eneste bestemmelse, som så kun har gyldighed som fremtrædelse i disse udviklede $\varnothing$ konomiske forhold. Ganske vist har det stadigt tilkommende friheds- og lighedsbedrag i cirkulationsakten en forskellig betydning på de forskellige niveauer af kapitalbegrebets udvikling. I Grundrisse antyder Marx det på følgende måde: »Betragtet ud fra videnskabens forl $\phi b$ fremtræder disse abstrakte bestemmelser (den simple cirkulation, forf.) netop som de første og fattigste; som de til dels også forekommer historisk; det mere udviklede som det senere. I det forhåndenvarende borgerlige samfunds helhed fremtræder denne sætten som priser og deres cirkulation etc. som den overfladiske proces, under hvilken der i dybet imidlertid foregår ganske andre processer, i hvilke denne individernes tilsyneladende frihed og lighed forsvinder $\ll .{ }^{59}$ Det borgerlige samfunds helhed, som ikke lader sig begribe med den simple varecirkulations »fattige « kategori, skilles altså ad i byttes overflademæssige proces på den ene side og i processen »i dybden « på den anden side; det frembringer henholdsvis befæster direkte permanent ufrihed og ulighed som processerende modsigelse i produktionens og reproduktionens ejendomsog tilegnelsesforhold. Den reale modsigelse, f.eks. den i lønarbejderens $\varnothing$ konomiske karaktermaske som modsigelse mellem ejendom og ikkeejendom, mellem varebesidder i byttet og personifikationen af ejendomsløshed i produktionsforhold og reproduktionsforhold, skyldes denne dualisme mellem »overflade « og »dybde« i det borgerlige samfund.

Den logiske ophævelse er først resultatet af kapitalens udvikling frem til dens $»$ mest fetichagtige form $«{ }^{60}$ hvor den kapitalistiske produktionsmådes mystifikation er fuldendt, ${ }^{61}$ hvor det skin, som stammer fra cirkulationen, ikke mere er udtrykt som sådan gennem dens modsigelse til faktisk ufrihed og ulighed, men finder sit sidestykke i produktionsagenternes sædvanlige bevidsthed

57. Grundrisse, s. 195; da. s. 112.

58. Grundrisse, s. 904.

59. Grundrisse, s. 159; da. s. 84; fremhævelse F \& H.

60. K. Marx, Theorien über den Mehrwert, i: MEW 26.3, s. 445.

61. Jvf. Das Kapital, III, s. 838; da. 3:4, s. 1069. 
om ejendoms- og tilegnelsesforholdene. Deres fordrejede fremtrædelse er det mystificeringsresultat, som kendetegner den kapitalistiske produktionsmådes væsentlige forhold »i dybden«, hvor den »overfladiske« cirkulation er det fænomen, som modsvarer den. ${ }^{62}$

Ved afslutningen af kapitalbegrebets udfoldelse i udviklingen af »Revenuen og dens kilder « (Den trinitariske formel ${ }^{63}$ ) er det metodiske niveau ansatsvis fremstillet, som Marx karakteriserer på forskellige steder som »overflade«: »revenuens form og revenuens kilde udtrykker den kapitalistiske produktions forhold i den mest fetichsagtige form. Det er dens eksistens, således som den ser ud på overfladen, skilt fra den skjulte sammenhæng og det formidlende mellemled ${ }^{64}$

62. Projekt Klassenanalyse overser denne centrale sammenhæng, f.eks. selv der, hvor de udvikler klassebevidsthedens opståelsesproces. Deres problemstilling er til at begynde med endnu tilstrækkelig: »Ved en undersøgelse af klassebevidsthedens udviklingsbetingelser må det først og fremmest afklares, hvordan fordrejelsen af de samfundsmæssige forhold, som også arbejderklassen er underkastet, kommer i stand, sådan at den accepterer kapitalforholdet som tilsyneladende naturform under normale reproduktionsbetingelser « (Projekt Klassenanalyse, Klassebewusstsein und Partei, Vestberlin 1972, s. 123 f). Ikke desto mindre nedbrydes lønarbejderens samfundsmæssige erfaringsområde derefter i to dele: i et skin og i et åbenlyst herskabsforhold. Hermed er arbejderbevidstheden modsætningsfyldt bestemt: i det formelle byttes sfære er han hildet i skinnets form (s. 124), men såsnart »arbejdskraften anvendes i kapitalens umiddelbare produktionsproces, bliver skinnet, som sagligt afhænger af varebesidderen, gjort relativt « (s. 124). Dermed er det korrekt stillede spørgsmål kun besvaret halvt. Det opfattes ikke som et problem, på hvilken måde produktionsprocessen fremtræder i bevidstheden, og hvorvidt fordrejelsen også angår den umiddelbare produktion. Hermed er ifølge Projekt Klassenanalyses opfattelse - egentligt alt afgørende sagt om overgangen fra 4. til 5. kapital i Kapitalens første bind med hensyn til lønarbejderens bevidsthed: de forlader frihedens og lighedens sfære (Das Kapital, I, s. 189 f; da. 1:1, s. 292) og betræder »gaveriet « (Das Kapital, I, s. 191; da. 1:1, s. 293). Det fremtræder i bevidstheden, sådan som det nu engang er, som herskabsforhold. Og resultatet af kapitalens cykliske bevægelse er derfor ophævelsen af »modsætningsfyldt bevidsthedsopfattelse « (s. 125), dannelsen af klassebevidsthed. For os er det derimod omvendt: når denne modsætning mellem produktion og cirkulation er erkendt, er denne produktionsmådes væsen samtidigt begrebet. Problemet er, hvordan totalprocessens mystifikation, som bringer den nøjere overflademæssige bestemmelse af cirkulationen i samklang med produktionen, hænger sammen. Totalprocessens mystifikation udvikler Marx i kapitlet »Revenuerne og deres kilder «, på samme måde som han allerede i Kapitalens første bind har udviklet lønnens forhold som revenu til sin kilde arbejdet. Til sin konstruktion gør Projekt Klassenanalyse nu også krav på lønfetichen; ganske vist ikke som »bestanddel « af den »trinitariske formel «, men som isoleret cirkulationsfanomen (s. 124). Ikke desto mindre ligger lønfetichens betydning (ligesom også de andre fordrejede fremtrædelsesformer af ny-værdien) netop i dens fordrejning af produktionsmåden. Den opløser antagonismen mellem nødvendigt arbejde og mer-arbejde og harmoniserer produktionen i lønarbejderens bevidsthed. (Jvf. også note 71 ).

63. Das Kapital, I, kap. 48-51.

64. Theorien über den Mehrwert, 26.3, s. 445. Begrebet »overflade« anvendes ikke altid af Marx på samme måde. I det følgende tjener det blot kun som betegnelse for produktionens »fetichagtige former«. På denne måde er det udviklet som terminologi i diskussionen i München, Erlangen, Bremen, etc. (Jvf. Cirkular 1 og 3, MARXISTISCHEN GRUPPE/Theoriefraktion, Erlangen). 
Den centrale tese i vores overvejelser går nu i den retning, at først med bestemmelsen af det borgerlige samfunds overflade gives de sammenhænge, som tillader at få greb om den borgerlige stats væsen; og det på en måde, som opløser vanskeligheder og meningsløsheder, som er indeholdt i de diskuterede statsafledninger.

Oversættelse Tyge Kjar

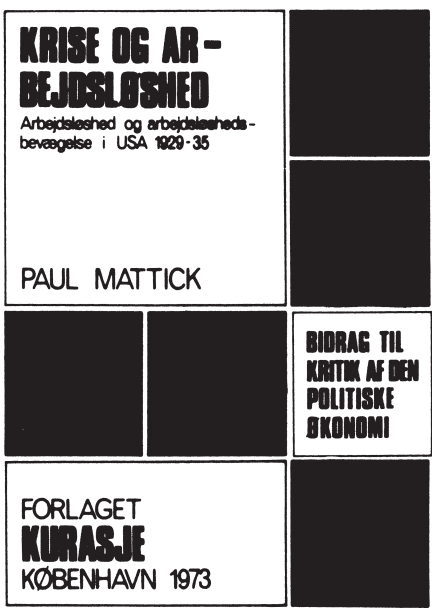

\section{PAUL MATTICK: \\ KRISE OG ARBEJDSLØSHED}

Matticks undersøgelse er i første omgang en konkret analyse af borgerskabets forhold til arbejdsløsheden $i$ en af de mest afgørende perioder af kapitalismens udvikling. Men samtidig formår han hele tiden at holde sin analyse indenfor rammen af den marxistiske teori om kriser og sammenbrudstendenser i det kapitalistiske system. Derfor er Matticks arbejde eksemplarisk og af væsentlig betydning.

120 sider, Pris 16.00 kr. 


\section{Anmeldelse:}

\section{Annti Kasvio: Stamokap. Den statsmonopolitiska ka- pitalismen i Finland. Nordisk Sommeruniversitets Skriftserie Nr. 1., Forlaget GMT, Kbh. 1973.}

\section{Mogens Holm}

Det er ikke denne anmeldelses ambition at give et udtømmende referat af A. Kasvio's STAMOKAP-teoretiske oplæg, ej heller at kommentere alle de problemer, som oplægget rejser, men at referere og diskutere nogle af oplæggets hovedproblemstillinger.

Annti Kasvios bog STAMOKAP er oplæg til et forskningsprojekt om statens rolle i det finske samfund. Projektet er udviklet siden sommeren 1972 indenfor Finlands Socialistiske Studierådgivning- och forskningscentral og videreført i en studiekreds indenfor Nordisk Sommeuniversitet frem til Sommeruniversitets møde sommeren 1973.

Ideen til gennemførelse af en undersøgelse af statsmonopolkapitalismens udviklingsniveau kommer fra Finlands Kommunistiske Partis 16. kongres (FKP), som mener at en sådan undersøgelses gennemførelse er nødvendig for udvikling af en korrekt politisk strategi.

Oplægget til projektet må forståes i forhold til FKP's politiske tradition, der velnok er den mest SUKP loyale i Europa, og i det hele taget ud fra de europæiske kommunistiske partiers aktuelle situation, hvor opfattelsen af de vesteuropæiske lande som statsmonopolkapitalistiske og opfattelsen af modsætningen mellem folk og monopol, som værende hovedmodsætningen, har fået et vældigt opsving i det sidste tiår, samtidig med at den politiske strategi og 
parolerne har koncentreret sig om folkefrontsideen, for demokratisk fornyelse af politikken og for socialisme.

Stamokap-oplægget er en ukritisk og loyal gengivelse af nogle SUKPkommunist inspirerede marxisters opfattelse af statsmonopolkapitalismens udvikling, sådan som den f. eks. forefindes i »Der Imperialismus der BRD«, Berlin 1972, »Der Staats monopolistische Kapitalismus«, Berlin 1972 og »Traité marxiste d'economie politique: le Capitalisme monopoliste d'etat I-II«, Paris 1971.

Annti Kasvio opfatter det som en første opgave at: »kartlägga den finska statsmonopolistiska kapitalismens historiska rötter: man bör undersöka vid vilka tidspunkter och i vilka situationer statens ekonomiska uppgifter har utvidgats, hur sammenkopplingen mellan staten och monopolborgerskapet har utvecklats och hurudana förandringar som inträffats i statens ideologiskpolitiska maskineri ${ }^{1}$

Projektet tager udgangspunkt i en kortlægning af det finske samfunds økonomiske historie for at finde frem til de reformer der har resulteret $i$ »att staten och statsekonomin altt fastera blivit redskab för den monopolistiska regleringen «. ${ }^{2}$

På grundlag af den historiske gennemgang af »statsmonopolkapitalismens « udvikling i Finland søges statsmonopolkapitalismen på den ene side fastlagt som en almen tendens i kapitalismens udvikling og som en udviklingsfase der på den anden side er kvalitativ forskellige fra monopolkapitalismen som sådan.

Hovedårsagen til statsmonopolkapitalismens udvikling antages at være »Det socialistiska väurldssystemets växande inflytande och skärpning av den kapitalistiska ekonomins inre motsätningar, som en följd av i synnerhet den tekniskvetenskapliga revolutionen, är de vigtigaste orsakarna till monopolkapitalismens utveckling till stasmonopolkapitalism $\ll .{ }^{3}$ Udviklingen af statsmonopolkapitalismen hidrører således fra faktorer der ligger udenfor det kapitalistiske samfund. Statsmonopolkapitalismen fastlægges definitorisk til at være den fase i det kapitalistiske samfundsudvikling, hvor staten, i modsætning til tidligere tiders mere tilfældige indgreb, nødvendigvis må gribe ind i økonomien, som monopolkapitalens redskab til sikring af monopolprofitter og til styring af nationaløkonomien, hvorved statsmonopolkapitalismen forøger monopolkoncernernes magt, idet monopolernes styrke forenes med statens styrke til et maskineri. ${ }^{4}$

\section{Statsteoriens udvikling: Forholdet mellem alment væsen og reale frem- trædelsesform}

I fors $\emptyset$ get på at konstituere begrebet statsmonopolkapitalisme tager Annti Kasvio udgangspunkt i den finske monopolkapitalismes historiske rødder for

1. Annti Kasvio, STAMOKAP. GMT Kbhvn 1973. s. 11.

2. Op. cit. s. 11.

3. Op. cit. S. 21.

4. Ibid. 
derefter at gennemføre en teoretisk bestemmelse af »utvecklingstendenser, som leder från den gamla monopolkapitalismen till den statsmonopolistiska kapitalismen . $^{5}$

D.v.s. at Annti Kasvio fors $\emptyset$ ger at udlede den borgerlige stats almene karakter på grundlag af den borgerlige stats konkrete fremtrædelsesformer. Ved denne fremgangsmåde opstår der et metodologisk problem. I forsøget på at begribe hvordan den borgerlige stat fungerer tager Kasvio direkte fat på den empiriske virkelighed, således som den kan perciperes via statistik, borgerlig $\emptyset$ konomi o.s.v. Statens almen væsen efters $\emptyset$ ges således blandt de myriader af mere eller mindre tilfældige fremtrædelsesformer, som en national stat har på et specifikt historisk tidspunkt, en efters $\varnothing$ gning der aldrig vil give resultat fordi de almene bestemmelser af den borgerlige stat ganske enkelt ikke fremtræder på samfundets overflade, men kun viser sig fordrejet form under påvirkning af de lokale og historiske betingelser der er til stede for denne eller hin borgerlige stat. Med udgangspunkt i »de koncentrations- och centralisationsprocesser, som förekommit i ekonomien, likesom uppkomsten av finanskapitalen «, ${ }^{6}$ forbigåes hele spørgsmålet om den samfundsmæssige totalkapitals udviklingstendenser, forholdet mellem total og enkeltkapital og modsætningerne i den kapitalistiske produktionsmådes udvikling, i ubemærkethed.

\section{Den statsmonopolkapitalistiske alliance}

På grund af sit empiriske udgangspunkt kommer stamokap-oplægget til at mangle en almen analyse af den borgerlige stat. Det er allerede forudsætning for, at man ved forsøget på straks at præcisere de konkrete empiriske opgaver, kaster sig over fremtrædelsesformerne og bider sig fast i den misforståelse, at staten og monopolerne er sammenflettede. I forsøget på at udrede statens funktionsmåde i det kapitalistiske samfund foreslåes det, at »En väsentlig del av undersökningen av den finska statsmonopolkapitalismen utgörs av klarläggandet av de konkrete åtgärder, med vilkas hjälp staten deltager i de olika stadierne av monopolkapitalets reproduktion i det den stöder monopolens kapitalackumulation ${ }^{7}{ }^{7}$

Staten får her en mekanisk rolle i den kapitalistisk dominerede samfundsformation. Denne rolle er dobbelt bestemt, dels som den styrke der ubegrundet og uforstået tillægges staten og dels i form af det komplot der indgåes, eller den »fusion « der foregår mellem stat og monopol og som gør disse væsener til en enhed. Spørgsmålet må være, i forbindelse med grundlaget for denne statsmonopolkapitalisme, som anvendes flittigere end det defineres, hvor de ikke-monopoliserede kapitalgrupper bliver af, når statens styrke forenes med monopolernes. Hvis en enhed mellem stat og monopol eksisterede, måtte vi for-

5. Op. cit. S. 11.

6. Op. cit. S. 12.

7. Ibid. 
vente en knusning af småborgerksabet og af den ikke-monopoliserede kapital, en knusning der hverken findes nogen empirisk eller teoretisk begrundelse for.

I udformningen af STAMOKAP-projektet referes flittigt til De kommunistiske Partiers og Arbejderpartiernes konferencer i Moskva. således f.eks. fra konferencen i 1969 hvor det »konstateredes«, at »Då den statsmonopolistiska kapitalismen ökar monopolkoncernernes makt i nationernes liv, förenar den monopolens styrka och statens styrka til ett maskineri, vars uppgift är att rädda det kapitalistiska systemet att så mycket som möjligt öka det imperialistiska borgerskabets profiter, med hjälp av utsugning av arbetarklassen och med hjälp av roffandet från vida befolkningslager « ${ }^{8}$ Det påstås $i$ »konstateringen « at bestræbelserne for at redde det kapitalistiske system foranstaltes ved forenelse af statens og monopolernes styrke til et maskineri. Denne opfattelse bygger på at staten og monopolerne forekommer som to selvstændige væsner der slås sammen til et maskineri.

Statsindgrebene fungerer iflg. STAMOKAP derved, at der indgås en alliance mellem stat og monopolkapital med det formål at sikre monopolkapitalens profitter ved at udsuge arbejderklassen. Eksistensen af en sådan alliance eller et sådant maskineri, forudsætter et direkte samarbejde mellem stat og de monopoliserede kapitalistgrupper. Alliancens eksistens forudsætter en eliminering af alle andre kapitaler end lige netop monopolkapitalen, forudsætter at hovedmodsætningen i det højt udviklede kapitalistiske samfund er mellem monopolkapital på den ene side og hele resten af samfundet på den anden side, og forudsætter endelig, at monopolkapitalen kan optræde som en samarbejdende enhed og at der altså ikke eksisterer konkurrence imellem monopol grupperne. Det sidste punkt forudsætter, at konkurrencen indenfor monopolkapitalen er elimineret.

\section{Monopolbegrebet}

Da hovedforudsætningen for STAMOKAPs statsopfattelse er sammenlægningen af statens styrke med monopolernes til et maskineri, bliver selve monopolbegrebet et vigtigt begreb at undersøge. Iflg. STAMOKAP er det den monopoliserede del af produktionen der dominerer hele den $\varnothing$ vrige samfundsmæssige produktion og monopoldannelserne sigter på opnåelse af profitter, der er større end den gennemsnitsprofit, der bliver den øvrige del af den samfundsmæssige kapital til del.

Blandt monopolerne består der iflg. denne opfattelse ikke nogen fri konkurrence og monopolerne er i stand til permanent at opretholde priser på et niveau, der ligger over varernes værdi. Denne påstand kan ikke kun opfattes som det forhold at priserne i det hele taget svinger omkring værdien. Påstanden om at det permanent forholder sig således, betyder at priserne i historisk perspektiv, for varer produceret i den monopoliserede sektor, kan holdes over deres værdi, og at monopolerne kan uddrage sig profitratens udligning. At monopolerne i historisk perspektiv unddrager sig profitratens udligning, implicerer at værdilo-

8. Op. cit. S. 21. 
vens virkning er ophævet indenfor den monopoliserede sektor, idet kapitalerne kun kan uddrage sig profitratens udligning ved at forhindre kapitalbevægelsen ind i høj - profit - produktionssektoren, hvorved kapitalerne ikke mere valoriseres i forhold til deres størrelse i overensstemmelse med værdiloven.

Denne opfattelse af monopolbegrebet og af forholdet mellem stat og monopol stemmer overens med den officielle øst-europæiske STAMOKAPopfattelse, som man bl.a. finder den i bogen »Der Staatsmonopolistichem Kapitalismus«, Dietz Verlag 1972. Her karakteriseres statmonopolkapitalismens to grundtræk således.

»Der wissenschaftliche Ausdruck für die beschriebenen verschiedenen Grundzüge lautet staatsmonopolisticher Kapitalismus, dessen zwei Hauptbestandteile heute

- die waschende Koncentration des Monopolkapitals und

- die Stärkung der Rolle des Staates sind, wobei letzere dadurch gekennzeichnet ist, dass die finanzierung der monopolistichen Grossproduktion aus staatlischen Mittel mit dem Ziel der Erzeugung von Monopolprofiten erfolgt«. (side 17)

For at forstå påstanden om eksistens af monopolprofitter og eksistensen af en monopoliseret kapitalgruppe, der kan producere under kvalitativt andre forhold end andre dele af den samfundsmæssige totalkapital, må vi dels se på indholdet af begrebet konkurrence og dels på begrebet monopol som økonomisk kategori. Kapitalens reproduktion er reproduktion af de stoflige elementer der indgår i den kapitalistiske produktion, det vil sige reproduktion af den konstante kapital, reproduktion af arbejderklassens leveomkostninger og reproduktion af merværdi. Formidlingen af den kapitalistiske reproduktion, det vil sige fortsættelse af den kapitalistiske værdiøgningsproces, kapitalens fortsatte eksistens som selvøgende værdi, forudsætter enkeltkapitalernes lige andel af den totale nyproducerede værdi.

Af kapitalens krav om lige valorisering følger som logisk begreb gennemsnitsprofitten, som formidles via konkurrencen.

Konkurrencen bringer til udtryk hvad der ligger i selve kapitalens begreb: At den på den ene side - som værdi - er ligeglad med brugsværdien af de fremstillede varer, at den på den anden side - som producent af brugsværdier - er afhængig af den stoflige sammenhæng mellem den samfundsmæssige produktion og reproduktion.

Stoflig reproduktion, ligelig værdiøgning af enkeltkapitalerner og konkurrencen mellem disse, er på det almene niveau den logisk fremkomne form for totalkapitalens reproduktion.

Monopolet er den specifikke form, hvori kapitalbegrebets indbyggede bestemmelser sætter sig igennem. Det er den form hvori enkeltkapitalerne fors $\emptyset$ ger at modsætte sig den almene udjævning af profitraten.

Monopolet er den specifikke form, hvori kapitalbegrebets indbyggede bestemmelser sætter sig igennem. Det er den form hvori enkeltkapitalerne fors $\emptyset$ ger at modsætte sig den almene udjævning af profitraten. 
Monopolet er kun en fremtrædelsesform af den »rene« form, hvori værdi$\emptyset$ gningen sætter sig igennem. Denne »rene« form er kun virkeliggørelsen af $»$ konkurrencen«, som abstraktion fra alle forhindringer, der kan stille sig ivejen for profitratens udligning.

For at kunne fremstille hvad konkurrencen er i almenhed, det vil sige hvorledes de mange kapitaler bidrager til reproduktion af totalkapitalen, må man gå ud fra den forudsætning, at disse kapitaler i deres realitet, frit kan bevæge sig i forhold til hinanden.

Den frie konkurrence er altså en abstraktion, den »rene form « for kapitalens bevægelser. I almenhed betegner konkurrencebegrebet denne bevægelse overhovedet, nemlig kapitalens tvang, at den skal værdiøges, betegner dens afhængighed af sammenhængen mellem samfundsmæssig produktion og reproduktion. Monopolet er blot den form, som konkurrencen, som abstraktion, fremtræder i under bestemte samfundsmæssige forhold, på et bestemt niveau af produktivkræfternes udvikling. Ved analysen af monopolet må man forstå kapitalens væsen, som abstraktion fra den konkrete virkelighed. Væsenet implicerer at monopolgrupperne ikke i historisk perspektiv kan sætte sig ud over profitratens udligning, ikke kan indkassere ekstraprofitter og i det hele taget ikke kan sætte sig ud over værdiloven.

Påstår man at monopolerne permanent kan indhøste monopolprofitter, fordi deres varer kan sælges til priser der ligger over deres værdi, medfører denne påstand, at værdiloven opfattes som værende sat ud af kraft indenfor det område af den samfundsmæssige produktion, som er omfattet af monopolerne.

Den af STAMOKAP fremførte monopolopfattelse forudsætter relationer der er uforenelige med den kapitalistiske produktionsmådes lovmæssigheder, det vil sige relationer der uforenelige med den kapitalistiske produktionsmåde, hvilket på den anden side betyder, at den kapitalistiske produktionsmåde i det hele taget ikke er i funktion i den monopoliserede sektor. Dette er STAMOKAP opfattelsen yderste og absurde konsekvens.

Den monopolitiske konkurrence har en anden karakter end den ikkemonopolitiske konkurrence, men dens eksistens forhindrer at monopolkapitalen, som en enhed, kan medvirke til kapitalismens eksistens ved at slå sin styrke sammen med statens styrke. Den forsatte eksistens af en ikkemonopoliseret produktionssektor forhindre også at kapitalismen kan sikres ved at monopolerne og staten indgår en alliance.

\section{STAMPOKAP og den keynesianske statsopfattelse}

Den statsopfattelse som STAMOKAP gruppen gør sig til talsmænd for peger frem imod en keynesiansk stat, der på kapitalens grund er i stand til at foranstalte en kvalitativ fornyelse. Disse perspektiver er indbygget i det forhold, at STAMOKAP gruppen ikke kan indse og ikke fatte grænserne for statens interventioner. En placering af staten som hverken mere eller mindre end monopolkapitalens 
allierede mod folket, som den instans der tilsikrer monopolkapitalen dens profit, indebærer at der ikke optræder grænser for rækkevidden eller størrelsesordenen af statens indgreb. At projektets perspektiv har taget denne retning hænger sammen med den manglende begrebsliggørelse af selve STAMOKAP begrebet, en mangel der afleder manglende indsigt $\mathrm{i}$ grænserne for statens indgreb.

Grænserne for statens indgreb afstikkes af selv samme forhold som er udgangspunkt for statens indgreb: stagnation i kapitalens akkumulation. Statens interventioner skal begrebsmæssigt afledes af lovmæssighederne for kapitalakkumulationens tendentielle udvikling. Her gør det sig gældende, at kapitalens akkumulationsgrundlag indsnævres ved profitraten tendentielle fald, hvorfor de ikke-profitable produktioner, som er nødvendige for totalkapitalens eksistens, må organiseres af totalkapitalens fællesvæsen: staten organiserer de ikke-profitable produktioner med midler der enten inddrives via skatterne eller ved midler der lånes.

De nævnte produktioner bliver naturligvis ikke mere profitable af at overtages af staten, og det gælder generelt at staten må overtage produktioner der ikke kan drives på kapitalistisk grundlag, men som ikke desto mindre er nødvendige for den samfundsmæssige totalkapitals fortsatte eksistens. Den statsorganiserede produktion er altså ikke-kapitalistisk produktion, er ikke-profitgivende produktion og produkterne indgår ikke på markedet på lige fod med kapitalistisk producerede varer. Staten fremmer kapitalakkumulationen ved på ikke-kapitalistisk grundlag at organisere den ikke profitable produktion. Ud fra hensynet til totalkapitalens krav om valorisering og fortsat eksistens kan staten enten selv producere eller indgå kontrakter med private enkeltkapitaler. Det vil sige, at statens relation til enkeltkapitalerne underordner sig totalkapitalens nødvendighed, og ikke omvendt, som det fremholdes af STAMOKAP gruppen, at statens væsen består i summen af dens relationer til enkeltkapitalerne eller til grupper (monopoler) af enkeltkapitaler.

Hvorvidt staten financierer produktionen via skatterne eller via låntagning, er i princippet ligegyldigt, blot har låntagning den fordel, at statsregnskabet ikke behøver at balancere år for år, idet statsbudgettet kun belastes med renter og afdrag af de optagne lån. Virkningen af låntagningen er at financiering af de offentlige foranstaltninger spredes over et langt tidsrum og således får den kapitalistiske akkumulations stagnationstendens et henholdende og tendentielt forl $\varnothing \mathrm{b}$.

Som sagt overtager staten kun de produktioner som ikke er profitable i kapitalistisk forstand. Uafhængigt af om midlerne til financiering af denne uproduktive produktion fremskaffes via skatterne eller via låntagning, kan disse midler kun stamme fra den produktive sektor. Det vil sige fra den del af den samfundsmæssige produktion, hvor der produceres kapitalistisk, hvor der produceres merværdi. De statsorganiserede produktioner kan meget vel involvere kapitalistiske producenter der tilsikres en merværdi og denne merværdies realisering, idet de producerede varer sædvanligvis er solgt inden de er producerede. Imid- 
lertid hidrører denne merværdi ikke fra den statsorganiserede produktionssektor selv, men optræder som en værdi, der via skatterne eller statens låntagning, er overført fra den produktive, kapitalistisk organiserede produktionssektor.

Når staten organiserer en stigende del af den samfundsmæssige produktion, bliver fradraget i merværdien, som beror på de offentlige udgifter, også stigende. De foranstaltninger der i værksættes for at sikre og fremme kapitalakkumulationen, bliver således en hæmsko for selv samme kapitalakkumulation jo længere de anvendes, fordi midlerne til disse foranstaltninger må tages fra den nyproducerede kapital, og dermed nedsættes akkumulationsvolumen.

»Blandings $\varnothing$ konomien « (d.v.s. den $\varnothing$ konomi hvor statsinterventionismen er på dagsordenen/MH) forudsætter at den statslige sektor udgør en mindre del af $\varnothing$ konomien. I modsat fald kunne den uprofitable statslige sektor ikke bæres af den profitable private sektor. Eftersom den statslige sektor ikke indbringer profit kan den heller ikke afkaste rente. Den uprofitable sektors omkostninger kommer til udtryk i statsgælden og dens forrentning, som må udlignes gennem beskatning af den profitable sektor. Med udbredelse af den statslige sektor vokser beskatningen af de enkelte kapitaler, hvorved den til disses ekspansion nødvendige profit formindskes tilsvarende «. ${ }^{9}$

Statsinterventionismen sætter således ikke en stopper for profitratens faldende tendens eller for den stagnerende kapitalakkumulation. Ej heller fjerner statsinterventionismen de kapitalistiske kriser. Tværtimod forøger statsinterventionismen modsætningerne, idet modsætningen mellem merværdiproduktion og merværdirealisering fremtræder som modsætningen mellem en realiseret merværdimasse og denne merværdimasses manglende værdigrundlag. Og de kapitalistiske kriser fjernes ikke, men uddybes i latent form, idet tidligere tiders kapitalistiske krisers rensende og helbredende virkning på den kapitalistiske produktion, udebliver.

Når STAMOKAP gruppen lukker øjnene for disse forhold, for grænserne for statsinterventionismen og statsinterventionismens udviklingstendens, forbliver de et halehæng til den keynesianske statsopfattelse.

\section{Om begrebet statsmonopolkapitalisme}

I STAMOKAP-projektet foreligger der ikke nogen definition af hvad statsmonopolkapitalisme er for noget. Udgangspunkt for hele analysen er statsmonopolkapitalismens eksistens, som en fase i kapitalismen som kvalitativt adskiller sig fra monopolkapitalismen. Denne opfattelse mangler enhver teoretisk begrundelse og der mangler en redegørelse for statsmonopolkapitalismens indhold og en begrundelse for hvorfor det er muligt og nødvengt at udskille statsmonopolkapitalismen fra monopolkapitalismen. Dels fremføres det at »man inte tillräckligt klart kan inse att den statsmonopolistiska kapitalismen

9. P. Mattick, Blandingsøkonomien og dens grænser, stencileret. 
fortfarende är monopolkapitalism $\ll^{10}$ og dels at »nöjer man sig med detta vägre man att se den kvalitative förändring som sker i de kapitalistiske produktionsförhållandena, då den statsliga inblandingen i ekonomien blir en absolut och nödvendig forutsätnning för monopolkapitalens utvidgade reproduktion «. ${ }^{11}$

Her må vi spørge hvordan to forhold samtidig kan være en og samme ting og kvalitativt forskellige.

I STAMOKAP bogen gives der flere mislykkede fors $\emptyset \mathrm{g}$ på definition af statsmonopolkapitalismen, definitionsfors $\emptyset \mathrm{g}$ der alle har en postulatorisk karakter, som ikke er teoretisk begrundet, men som tager udgangspunkt i de fremtrædelsesformer, som staten har i flere vesteuropæiske lande. Det foreslås således at statsmonopolkapitalismen er den fase af monopolkapitalismen, hvor staten ikke mere bare blander sig tilfældigt i det økonomiske liv, men permanent må gribe ind. ${ }^{12}$ Et andet sted foreslås at statsmonopolkapitalisme er den fase hvor statens magt og monopolernes magt sammenslås til et maskineri. ${ }^{13}$

Efter at have konstateret at Lenin anvender en 3 deling af kapitalismen, nemlig 1. den tidlige kapitalisme, 2. konkurrencekapitalismen og 3. det imperialistiske stade, formuleres endnu en tredie definition af statsmonopolkapitalismen, som værende det stade af den kapitalistiske udvikling, hvor monopoliseringsgraden hæves op til et nyt hidtil uset stade.

Den opfattelse af staten som de to først nævnte punkter bygger på, nemlig at staten tidligere nu og da kunne gribe ind i økonomien, når den fandt det for godt, medens den under statsmonopolkapitalismen bliver nødt til at gennemføre indgreb, og at staten slår sin styrke sammen med monopolernes styrke, bygger på staten som en selvstændig og fast mekanisme i samfundet. Staten fremtræder som et fast organ der har i sin egen styrke (der under visse betingelser kan slås sammen med monopolernes styrke) og som et organ der har sin egen vilje der kan bestemme om den vil gribe ind eller ej.

Denne statsopfattelse er i bund og grund positivistisk og står i modstrid med den marxistiske statsopfattelse, iflg. hvilken statens funktion kun kan afledes af kapitalforholdet og at den konkrete analyse af statens fremtrædelsesformer må udvikles på denne baggrund. Det væsentligste ved den moderne stat er at den fungerer i forhold til kapitalen, men udenfor kapitalforholdet. Staten er det udenfor kapitalen stående organ, der fungerer for at sikre den kapitalistiske produktionsmådes fortsatte eksistens.

\section{STAMOKAP projektets politiske strategi}

På samme måde som udviklingen af de såkaldte STAMOKAP teorier er foregået i tæt kontakt med de europæiske kommunistpartier er det finske projekt

10. Annti Kasvio Op. cit. S. 22.

11. Ibid.

12. Op. cit. S. 20.

13. Op. cit. S. 21. 
sammenknyttet med ophavsmændenes politiske strategi. Som det blev nævnt i indledningen blev initiativet til projektet taget på FKP's 16. kongres, idet kongressen antog projektets gennemførelse som en forudsætning for anlæggelse af en korrekt politisk strategi.

Kongressens syn på forholdet mellem teori og politisk praksis er korrekt i den udstrækning man regner teoretisk afklaring som forudsætning for politisk handling. Men desværre viser det sig at man i STAMOKAP projektet $\mathrm{g} \emptyset \mathrm{r}$ denne kongresbeslutning til skamme, idet man går ud fra den politiske strategi, fastslår strategiens hovedelementer, som f. eks. opdeling af samfundet i folket og monopolkapital, og »konstateringen « af alliancen mellem stat og monopol, går ud fra disse begreber som kendsgerninger og udvikler på dette grundlag projektet.

På denne måde får projektet ikke nogen selvstændig status i forhold til den politiske strategi og kan derfor ikke anvendes til at korrigere en sådan politisk strategi, men får i stedet karakter af en efterrationalisering af en allerede fastlagt strategi. Ud over de $\varnothing$ vrige problemer med projektet, som er kommenteret ovenfor, er der på dette plan endnu et problem. Projektets politiske sammenknytning til den af SUKP dirigerede linie (som der citeres til adskillige steder) afgrænser de problemstillinger som projektet beskæftiger sig med og der forekommer nogle politiske begrundelser for projektets udformning som i sig selv lukker perspektivet for udvikling af statsteori endnu inden projektet er kommet igang.

Som et eksempel på denne sammenhæng kan man bide mærke i den målsætningsformulering, der er knyttet til projektets gennemførelse. Det hedder her, at helhedsanalysen skal gennemføres for at kunne udarbejde et demokratisk program som formår at mobilisere en bred antimonopolistisk massebevægelse.

Hovedmodsætningen i det kapitalistiske samfunds placeres her som modsætningen mellem monopolkapitalen og folket. Mobilisering på dette grundlag er en nederlagsstrategi, fordi dette »folk «, der er resten af samfundet når monopolborgerskabet er trukket fra, indeholder allehånde reaktionære elementer, der ikke lader sig mobilisere i kampen mod monopolkapitalen eller mod staten. Man søger i dette program at mobilisere lag af befolkningen, der er monopolborgerskabets reaktionære halehæng. Målet med programmet er ikke at knuse kapitalismen, men monopolkapitalen, hvilket ikke er ensbetydende med en knusning af kapitalismen som sådan. Yderligere mobiliseres der om dannelse af et demokratisk program, det vil sige et program der har til hensigt at gennemføre en fornyelse af de nuværende samfundsmæssige institutioner, forny dem, men bevare dem. 


\section{politiske}

\section{arbejdstekster}

nr. 1

kr. 6.00

kritik af nationalokonomien

nr. 2

kr. $\quad 7.00$

elementer til analyse

af uddannelsessektoren

nr. 3-4

kr. 14.00

\section{KRISETEORI}

Nollte: Diskussionerne om kriseteori i socialdemokratiet før 1. verdenskrig. Cogoy: Profitratens fald og akkumulationsteori - et svar til Sweezy.

Mattick: Om Marx' akkumulations- og sammenbrudsteori.

Schmiede: Grundproblemer i Marx akkumulationsog kriseteori.

nr. 5 indholdende bl.a.

Cogoy: værditeori og statsudgifter kommer medio maj.

nr. 6 stat og arbejderbevægelse kommer primo september.

\section{ABONNEMENT \\ $1-4 \quad 18.00$ \\ $2-4 \quad 15.00$ \\ 5-8 28.00}

bestilles ved at indsende beløbet til

giro 211444

politiske arbejdstekster kollektivets publikationsgruppe Rosenborggade 15 1130 København K.
TIDSSKRIFTER I

ABONNEMENT

HOS KURASJE:

\section{PROBLEME DES \\ KLASSENKAMPFS}

\section{MEHRWERT}

\section{ERZIEHUNG UND KLASSENKAMPF}

KAPITALISTATE

ARBEITERPOLITIK
(REPRINT)

DIE KOMMUNISTISCHE INTERNATIONALE (REPRINT)

Forlang katalog og tegn abonnement hos:

KURASJE'S BOGIMPORT KRYSTALGADE 16/14 1172 KØBENHAVN $K$

som også har andre tyske og danske tidsskrifter i løssalg. 
KAPITALISMENS VALUTAKRISER

Af Elmar Altvater

Introduktion af Jens Brinch

Valutakrise, guldkrise og dollarkrise er forhold, som den kapitalistiske udvikling mere og mere gør til hverdagsbegivenheder for os. Nyhedsformidlingen fortæller os, at den »internationale spekulation « veksler franc til guld, dolIar til D-mark eller sterling til yen. Vi hører, at tilliden til dollaren falder i takt med Watergate-sagens afsløringer osv. Vi hører ikke, at den internationale spekulation ikke er en valutamafia, men de europæiske centralbanker og multinationale koncerner. Vi hører heller ikke, at dollarkursen ikke blot er et spørgsmål om tillid, men snarere om økonomisk potentiale i kapitalistisk form, altså for dollarens vedkommende et spørgsmål om manglende kapitalistisk ekspansionskraft for den amerikanske kapital.

Det, som trods alt fremstår med al ønskelig tydelighed er, at der tilsyneladende ikke længere er nogen; der vil have amerikanske dollar eller engelske pund.

Den foreliggende bog er et forsøg på at forklare hvorfor. I sin forklaring på valutasystemets kriser er den anderledes, idet den ikke lader sig nøje med at forklare, at årstider og konjunkturer skifter, men hellere vil vide hvorfor de gør det.

130 sider, stort format, mange kurver og tabeller $27.75 \mathrm{kr}$. VI HAR GENOPTRYK TIL NEDSAT PRIS AF:

Harry Magdoff:

Imperialismens epoke

$15.00 \mathrm{kr} . \quad$ (før 1975)

Pierre Jalee:

Imperialismen i 70'erne

19.75 kr. (før 23.00)

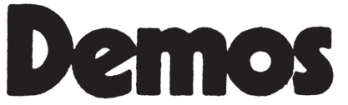

SOCIALISTISK FORLAG OG BOGHANDEL

GR $\emptyset$ NNEGADE 37

1107 KØBENHAVN K 


\section{NYHED FRA KURASJE}

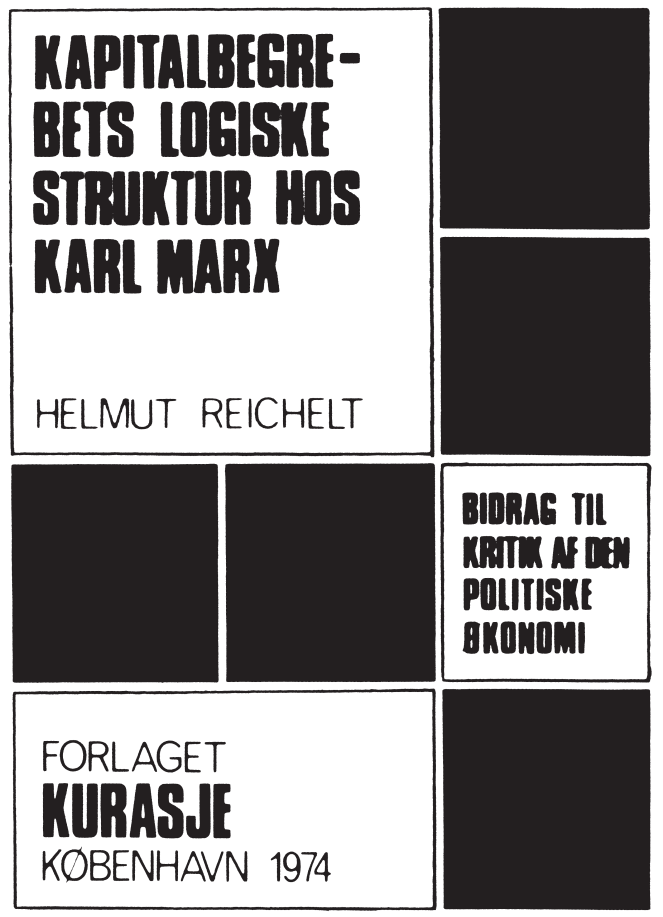

\section{HELMUT REICHELT:}

Kapitalbegrebets logiske struktur hos Karl Marx.

Ca. 280 sider, Pris kr. 28.50.

På baggrund af Marx' kapitalen og Grundrids udledes her de metodologiske og logiske strukturer, som er indeholdt i den marxske metode. Han viser, at den dialektiske fremstilling og udarbejdelse af begreber og kategorier samtidig er en fremstilling af selve kapitalismen, men også en omfattende kritik af borgerlig videnskab. Reichelts bog er nok et af de enkeltværker, der har haft størst betydning i den tyske marxistiske debat gennem de sidste år. 


\section{KURASJE}

ADRESSE:

KURASJE, Krystalgade 16/14, 1172 København K, Danmark.

GIRO NR.:

166044.

LøSSALG:

Nr. 1: udsolgt

Nr. 2-3: udsolgt

Nr. 4: $\quad 7,50$ kr.

Nr. 5-6: 20,00 kr.

Nr. 7: $\quad 10,00 \mathrm{kr}$.

Nr. 8: $\quad 10,00 \mathrm{kr}$.

Nr. 9: $\quad 15,00$ kr.

ABONNEMENT: Nr. 1-4: udsolgt

Nr. 5-8: 30,00 kr.

Nr. 9-12: 40,00 kr.

Bestilling sker ved indbetaling af ét af disse beløb. Anfør på girotalonen, hvad betalingen dækker. 